\title{
EFFECTS OF RUNOFF CONTROLS ON THE QUANTITY AND QUALITY OF URBAN RUNOFF AT TWO LOCATIONS IN AUSTIN, TEXAS
}

By Clarence T. Welborn and Jack E. Veenhuis

U.S. GEOLOGICAL SURVEY

Water-Resources Investigations Report 87-4004

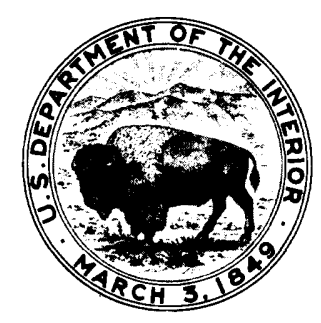

Prepared in cooperation with the CITY OF AUSTIN

Austin, Texas 
UNITED STATES DEPARTMENT OF THE INTERIOR

DONALD PAUL HODEL, Secretary

GEOLOGICAL SURVEY

Dall as L. Peck, Director

For additional information

write to:

District Chief

U.S. Geological Survey

649 Federal Building

300 E. Eighth Street

Austin, TX 78701
Copies of this report can be purchased from:

Books and Open-File Reports Section Western Distribution Branch

U.S. Geological Survey, MS 306 Box 25425, Federal Center

Denver, CO 80225 


\section{CONTENTS}

Page

Abstract-1-

Introduction-1.- 3

Purpose and scope--

Approach-1-

Cl imate---1-

Acknowl edgments---

Description of Barton Creek Square Shopping Center watershed-........... 5

Description of Alta Vista Pl anned Unit Development watershed-_........... 11

Data avail ability and collection-_. 15

Effects of runoff controls at Barton Creek Square Shopping Center-_...-..- 17

Rainfal l-runoff characteristics-_- 17

Water budget-_.

Qual ity of water-an 30

Discharge-weighted concentrations-_- 30

Fecal-col iform and fecal-streptococci bacteria-_......... 30

Biochemical oxygen demand-_- 41

Chemical oxygen demand-_. 41

Total organic carbon-_.-. 43

Suspended, dissolved, and vol atile dissolved sol ids_._.... 43

Nitrogen-..-_. 45

Phosphorus-_-_-_-_ 45

Dissolved trace el ements-_- 48

Measured peak concentrations-_.

Loads-.--

Effects of runoff controls at Alta Vista-

Rainfall-runoff characteristics-_. 66

Qual ity of water-_. 68

Di scharge-weighted concentrations-_- 75

Measured peak concentrations- 75

Summary and conclusions-0

Sel ected references-

Glossary of selected water-qual ity terms 


\section{ILLUSTRATIONS}

Figure 1. Map showing location of study area-n 4

2. Map showing watershed of Pond 1 at Barton Creek Square Shopping Center.... 6

3. Diagram showing schematic cross section of Pond 1 at Barton Creek Square Shopping Center-..... 8

4. Photograph showing Pond 1 at Barton Creek Square Shopping Center and outflow control structure-.... 9

5. Photographs showing inflow control structure for Pond 1 at Barton Creek Square Shopping Center-_... 10

6. Map showing watershed of the Alta Vista Planned Unit Devel opment-_... 12

7. Photographs showing gaging stations and runoff controls at Al ta Vista Pl anned Unit Development_-_. 13

8. Photographs showing gaging station and runoff controls at Al ta Vista PI anned Unit Development_-_. 14

9-14. Graphs showing rainfall, discharge, and time of discrete sample collection at inflow and outflow stations at the Barton Creek Square Shopping Center for selected storms:

9. September and October 1982 18

10. November 1982-May 1983- 19

11. May-September 1983

12. October 1983-February 1984-_ 21

13. March-June 1984-_. 22

14. July and August 1984 23

15-31. Graphs showing:

15. Relationship of peak discharges for selected storms between inflow and outflow stations at Barton Creek Square Shopping Center-_ 26

16. Peak and mean discharge during storm runoff from outflow station at Barton Creek Square Shopping Center-..-.-.-- 27

17. Relationship between storm rainfall and runoff volumes in the inflow and outflow stations at Barton Creek Square Shopping Center-..... 29

18. Densities of fecal-col iform and fecal-streptococci bacteria in the inflow and outflow of Pond 1 at Barton Creek Square Shopping Center-_... 31

19. Discharge-weighted concentrations of biochemical oxygen demand, chemical oxygen demand, and total organic carbon in the inflow and outflow of Pond 1 at Barton Creek Square Shopping Center-a 42

20. Discharge-weighted concentrations of suspended solids, dissolved solids, and volatile dissolved sol ids in the inflow and outflow of Pond 1 at Barton Creek Square Shopping Center-

21. Discharge-weighted concentrations of total nitrogen, total organic plus ammonia nitrogen, total nitrite plus nitrate nitrogen, and total phosphorus in the inflow and outflow of Pond 1 at Barton Creek Square Shopping Center-a 


\section{ILLUSTRATIONS--Continued}

Page

Figures 15-31. Graphs showing--Continued

22. Discharge-weighted concentrations of dissolved lead, dissolved iron, and dissolved zinc in the inflow and outflow of Pond 1 at Barton Creek Square Shopping Center
ensities of fecal-col iform bacteria in discrete

23. Densities of fecal-col iform bacteria in discrete
samples collected from the gaged inflow and outflow stations at Barton Creek Square Shopping Center-.....

24. Densities of fecal-streptococci bacteria in discrete samples collected from the gaged inflow and outflow stations at Barton Creek Square Shopping Center-arich oxygen demand
Concentrations of biochemical oxy

25. Concentrations of biochemical oxygen demand
in discrete samples collected from the gaged inflow and outflow stations at Barton Creek Square Shopping Center-_._-_._. 52

26. Concentrations of suspended solids in discrete samples collected from the gaged inflow and outflow stations at Barton Creek Square

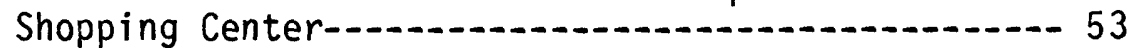

27. Concentrations of dissolved solids in discrete samples collected from the gaged inflow and outflow stations at Barton Creek Square Shopping Center-................ 54

28. Concentrations of total organic plus ammonia nitrogen in discrete samples collected from the gaged inflow and outflow stations at Barton Creek Square Shopping Center-_-_-_-_- 55

29. Concentrations of total nitrite plus nitrate nitrogen in discrete samples collected from the gaged inflow and outflow stations at Barton Creek Square Shopping Center-_..-..- 56

30. Concentrations of total nitrogen in discrete samples collected from the gaged inflow and outflow stations at Barton Creek Square Shopping Center-...... 57

31. Concentrations of dissolved iron in discrete samples collected from the gaged inflow and outflow stations at Barton Creek Square Shopping Center-

32-36. Graphs showing rainfall, discharge, and time of discrete sample collection at Alta Vista inflow station for selected storms:

32. September 1982-March 1983

33. May-August 1983

34. September-December 1983 71

35. February-May 1984 72 


\section{ILLUSTRATIONS--Continued}

Paye

Figures 32-36. Graphs showiny rainfall, discharye, and time of discrete sample collection at Alta Vista inflow station for selected storms:--Continued

36. June and July 1984

37. Diagram showiny relationship between storm rainfall and runoff volumes at the Alta Vista inflow station-.--- 74 38-51. Graphs showiny:

38. Densities of fecal-coliform and fecalstreptococci bacteria in the inflow and outflow at Alta Vista

39. Discharye-weighted concentrations of biochemical oxyyen demand, chemical oxyyen demand, and total oryanic carbon in the inflow and outflow at Alta Vista - 77

40. Discharye-weighted concentrations of suspended solids, dissolved solids, and volatile dissolved solids in the inflow and outflow at Alta Vista-............... 78

41. Discharye-weighted concentrations of total nitroyen, total oryanic plus ammonia nitroyen, total nitrite plus nitrate nitroyen, and total phosphorus in the inflow and outflow at Alta Vista-1..-.

42. Discharye-weiyhted concentrations of dissolved lead, dissolved iron, and dissolved zinc in the inflow and outflow at Alta Vista.................. 82

43. Densities of fecal-coliform bacteria in discrece samples collected from the yayed inflow and

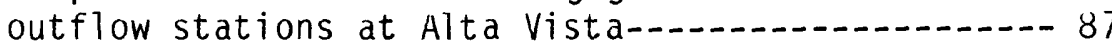

44. Densities of fecal-streptococci bacteria in discrete samples collected from the yayed inflow and outflow stations at Alta Vista_........... 88

45. Concentrations of biochemical oxyyen demand in discrete samples collected from the yayed inflow and outflow stations at Alta Vista-_._........ 89

46. Concentrations of suspended solids in discrete samples collected from the yayed inflow and outflow stations at Alta Vista-

47. Concentrations of dissolved solids in discrete samples collected from the yayed inflow and outflow stations at Alta Vista-................ yl

48. Concentrations of total oryanic $\rho 1$ us ammonia nitroyen in discrete samples collected from the yayed inflow and outflow stations at Alta Vista--.- 92

49. Concentrations of total nitrite plus nitrate nitroyen in discrete samples collected from the gayed inflow and outflow stations at Alta Vista---- 93 


\section{ILLUSTRATION--Continued}

Page

Figure 38-51. Graphs showing--Continued

50. Concentrations of total nitrogen in discrete samples collected from the gaged inflow and outflow stations at Alta Vista......................

51. Concentrations of dissolved iron in discrete samples collected from the gaged inflow and

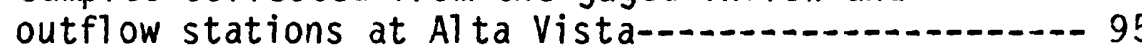


Table 1. Rainfall-runoff characteristics of selected storms at Barton Creek Square Shopping Center-.............................. 24

2. Water budget of sel ected storms at Barton Creek Square Shopping Center-.................................................... 32

3. Water analyses of the inflow to Barton Creek Square

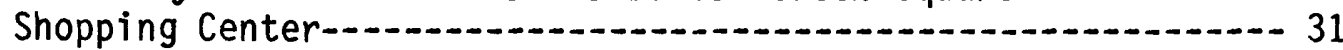

4. Water analyses of samples from section B of the ungaged drainage area at Barton Creek Square Shopping Center-.........- 36

5. Water analyses of samples from section $D$ of the ungaged drainage area at Barton Creek Square Shopping Center-........- 37

6. Water analyses of the outflow at Barton Creek Square

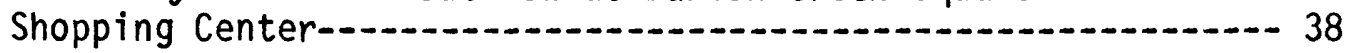

7. Densities of fecal-coliform and fecal-streptococci bacteria and removal efficiencies at Barton Creek Square Shopping

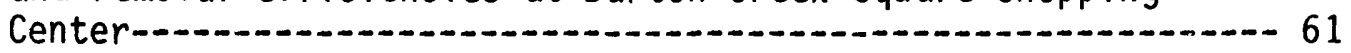

8. Loads for biochemical oxygen demand, chemical oxygen demand, and total organic carbon and removal efficiencies at Barton Creek Square Shopping Center-......................... 62

9. Loads for suspended sol ids, dissolved solids, and dissolved vol atile solids and removal efficiencies at Barton Creek

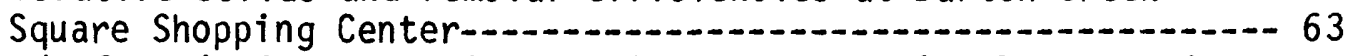

10. Loads for nitrite plus nitrate nitrogen, organic plus ammonia nitrogen, and total nitrogen and removal efficiencies at Barton Creek Square Shopping Center-a. 64

11. Loads for dissolved lead, dissolved iron, and dissolved dissolved zinc and removal efficiencies at Barton Creek Square Shopping Center-......................................... 65

12. Rainfall-runoff characteristics of selected storms at

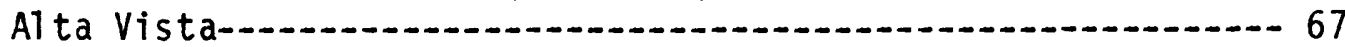

13. Water analyses of the inflow at Al ta Vista-...................- 82

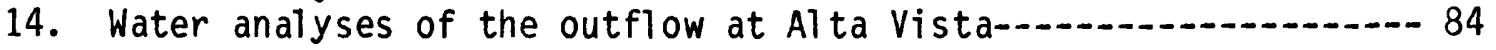




\section{METRIC CONVERSIONS}

The inch-pound units of measurements used in this report may be converted to metric (International System) units by using the following conversion factors:

Multiply inch-pound unit

By To obtain metric unit acre 4,047 square meter $\left(m^{2}\right)$

acre-foot (acre-ft) 0.001233 cubic hectometer $\left(\mathrm{hm}^{3}\right)$

cubic foot per second $\left(\mathrm{ft}^{3} / \mathrm{s}\right)$

0.02832 cubic meter per second $\left(\mathrm{m}^{3} / \mathrm{s}\right)$ degree Fahrenheit $\left({ }^{\circ} \mathrm{F}\right)$ $5 / 9\left({ }^{\circ} \mathrm{F}-32\right)$ degree Celsius $\left({ }^{\circ} \mathrm{C}\right)$

foot $(f t)$

0.3048 meter $(\mathrm{m})$

inch (in.) 25.40 millimeter (Imrn)

mile (mi) 1.609 kilometer $(\mathrm{km})$

National Geodetic Vertical Datum of 1929 (NGVD of 1929): A geodetic datum derived from a general adjustment of the first-order level nets of both the United States and Canada, formerly called "mean sea level." 



\title{
EFFECTS OF RUNOFF CONTROLS ON THE QUANTITY AND QUALITY \\ OF URBAN RUNOFF AT TWO LOCATIONS IN AUSTIN, TEXAS
}

By

$\mathrm{Cl}$ arence $\mathrm{T}$. Welborn and Jack E. Veenhuis

\begin{abstract}
Rapid urban development in the Austin metropolitan area, Texas, is causing concern about increasing peak discharges from storm runoff and the degradation of the quality of water in receiving streams, lakes, and aquifers. In an attempt to decrease peak discharges and improve water quality, runoff controls are being required in some watersheds. This report summarizes the precipitation, streamflow, and water-quality data collected from September 1982 to September 1984 upstream and downstream from runoff controls at two locations, and presents the effects of these runoff controls on streamflow and the qual ity of runoff water. The two controls are a detention and filtering pond near Barton Creek Square Shopping Center, a large shopping center southwest of downtown Austin, and a grass-swale control in the Al ta Vista Pl anned Unit Development, a multiple-family housing area.
\end{abstract}

At Barton Creek Square Shopping Center, rainfall for the storms analyzed ranged from 0.14 to 2.88 inches. The rainfall rate for the September 7, 1983, storm exceeded the 100-year return period for the 5- and 10-minute duration and was equal to the 50-year return period for the 15-minute duration. Peak discharge at the inflow station to the detention pond was closely related to the maximum rainfall during a 5-minute period and occurred about 10 minutes 1 ater. The maximum inflow at this station was 185 cubic feet per second and appeared to be the limit of the storin sewer system. For small- and moderate-sized storms, the runoff is contained in the detention pond and passes through a filter system. Runoff from 1 arge storms overflows into the drop outlet. For storms contained in the pond, peak discharges at the outflow station generally were less than 3.1 cubic feet per second. As time passed, the outflow peak discharges tended to decrease as a result of reduced permeability of the filter. Cleaning the filter appeared to increase the peak flows but did not restore them to the previous 1 evel. The runoff-rainfall ratio averaged 0.85 at the inflow station and 0.36 at the outflow station. A water budget shows unexplained losses to average 20 percent.

At the Barton Creek Square Shopping Center, discharge-weighted densities of fecal-coliform and fecal-streptococci bacteria and discharge-weighted concentrations of biochemical oxygen demand, chemical oxygen demand, total organic carbon, suspended solids, total ammonia plus organic nitrogen, and total phosphorus generally were larger in the inflow than in the outflow. Dischargeweighted concentrations of dissolved lead, dissolved iron, and dissolved zinc generally were small in both the inflow and outflow; however, the larger 
discharge-weighted concentrations of these constituents generally were found in the inflow. Discharge-weighted concentrations of vol atile dissolved solids were smaller in the inflow than in the outflow for 10 of the 22 storms analyzed. Discharge-weighted concentrations of total nitrite plus nitrate nitrogen and dissolved solids generally were much smaller in the inflow than in the outflow. It is likely that organic and ammonia nitrogen trapped in the pond from previous storms and in the inflow water as it flows through the pond is being oxidized to nitrite and nitrate nitrogen. Similiarly, dissolved solids retained in the filter or on the bed of the pond from previous storms are being leached to the outflow.

Measured peak concentrations or densities of most constituents in the inflow were significantly larger than those in the outflow for most constituents. An exception was noted for concentrations of total nitrite plus nitrate which were larger in the outflow than the inflow as indicated by discrete sample analysis for six storms.

Loads of most constituents and total numbers of bacteria were significantly larger in the inflow than in the outflow. The total numbers of bacteria were reduced by approximately 80 percent. Average removal efficiencies for suspended solids, biochemical oxygen demand, total phosphorus, total organic carbon, chemical oxygen demand, and dissolved zinc ranged between 60 and 80 percent. The average loads of dissolved solids were approximately 13 percent 1 arger in the outflow than the inflow. Average loads of total nitrite plus nitrate nitrogen were approximately 110 percent larger in the outflow than in the inflow. The increase in loads of these constituents is due to material being leached from the bed of the pond or from the filter system.

At Alta Vista, rainfall for the storms analyzed ranged from 0.25 to 2.00 inches. The maximum rainfall intensity was 0.30 inch for a 5-minute interval. The runoff-rainfall ratio averaged 0.42 and appeared to be evenly distributed about the mean ratio line. The peak discharge at the inflow station to the grass-covered swale area was 0.93 cubic foot per second. Inaccuracies of discharge at the outflow station and variations in the ungaged drainage area with the size of the storm prevented a hydrologic analysis of the basin above this station.

Discharge-weighted concentrations of total phosphorus were 1 arger in the outflow than in the inflow for each of the 19 storms analyzed. Dischargeweighted concentrations of dissolved solids, volatile dissolved solids, biochemical oxygen demand, chemical oxygen demand, and total organic carbon were 1 arger in the outflow than in the inflow for at least 12 of the 19 storms analyzed. Discharge-weighted densities of fecal streptococci were decreased between the inflow and outflow, with discharge-weighted densities of fecal streptococci being less in the outflow for 15 of the 19 storms analyzed. Because of the relatively small variations in concentrations and densities of constituents between the inflow and outflow sites, and because of the errors in discharge at the outflow gage, it is not feasible to determine the effct of the grass-covered swales on discharge-weighted concentrations and densities of water-qual ity constituents.

Discrete concentrations or densities of most constituents were not decreased. Peak concentrations of dissolved solids in the outflow exceeded peak concentrations in the inflow for all five of the storms analyzed with discrete 
samples. Peak concentrations of suspended solids, total ammonia plus organic nitrogen, total nitrite plus nitrate nitrogen, total nitrogen, and dissolved iron were larger in the outflow than in the inflow for four of the five storms analyzed. Load-removal efficiencies of water-quality constituents could not be determined because of inaccuracies in measuring discharge at the outflow site.

\section{INTRODUCTION}

The development of urban areas alters the quantity and quality of runoff that enters streams, lakes, reservoirs, and aquifers. Rapid urban development in the Austin metropolitan area, Texas, is causing concern about the impairment of the quality of water in streams, Lake Austin, Town Lake, and the Edwards aquifer. Lake Austin and Town Lake are water-supply reservoirs for the city of Austin and many nearby metropolitan areas. The Edwards aquifer south of the Colorado River near Austin is the source of water supply for many incorporated areas and urban developments in the vicinity of Austin, and discharges to Barton Springs, a popular recreation area.

The city of Austin requires that runoff controls be provided for developments in certain watersheds to reduce peak flows, or to minimize the impairment of the quality of water in streams and aquifers, or both. Local data are not available to determine the effectiveness of runoff controls in improving the quality of stormwater runoff, or the effect of these controls on reducing peak discharges. In order to help design future runoff controls, data are needed by city $\mathrm{planners}$ and developers to determine the effectiveness of present control structures. In 1982, the U.S. Geological Survey, in cooperation with the city of Austin, began a study to determine the effectiveness of runoff controls on the quantity and quality of urban runoff at two locations in Austin. These locations represent two types of runoff control structures that are commonly used in the Austin metropolitan area.

\section{Purpose and Scope}

This report describes the results of a study to determine the quantity and quality of runoff from a shopping center and a multiple-family residential development, and to determine the effectiveness of the runoff controls (detention pond and grass swale) on the storm runoff at the two locations. One site, Barton Creek Square Shopping Center (BCSSC), is a large shopping center located southwest of downtown Austin (fig. 1). The other site, Alta Vista Pl anned Unit Development (Alta $V$ ista), is a multiple-family residential neighborhood located in northwest Austin (fig. 1). The data-collection period began in September 1982 and concluded in September 1984.

\section{Approach}

To meet the study objectives, rain gages and streamflow and water-quality stations were established and operated at the principal points of inflow and outflow from the runoff control structures at each location. Rainfall and streamflow data were analyzed to show the rel ation between rainfall and runoff, the change in peak flow between the inflow and outflow of the runoff controls, and the water budget. Water-quality data were analyzed by comparing the discharge-weighted and peak concentrations and loads of selected constituents computed at the inflow station with values computed at outflow stations. 


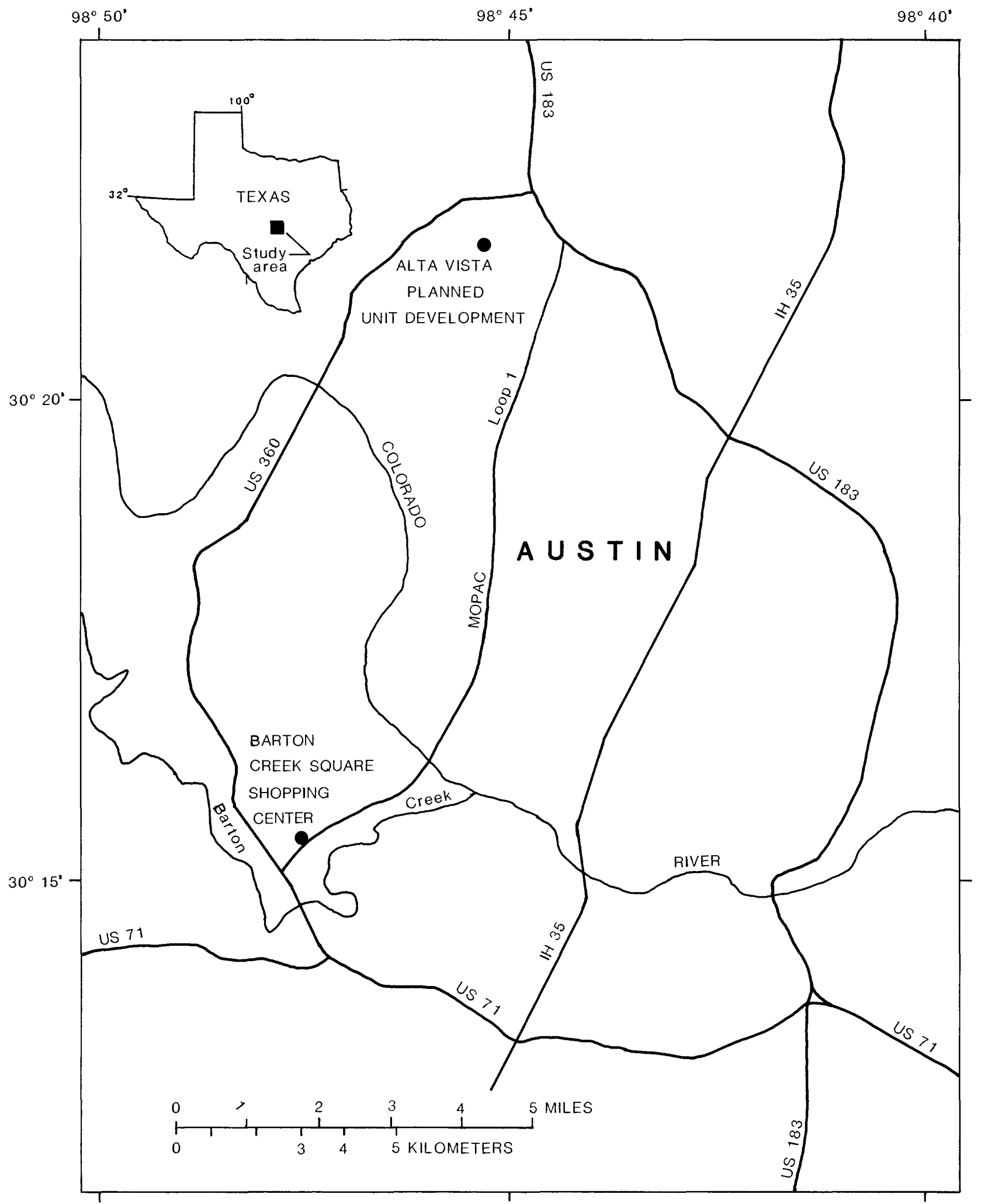

Figure 1.--Location of study area. 


\section{Climate}

The climate of the Austin area is humid subtropical with hot summers and mild winters. The average-annual temperature is about $68^{\circ} \mathrm{F}$. The mean-maximum

temperature for July is about $95^{\circ} \mathrm{F}$, and the mean-minimum temperature for January is about $41^{\circ} \mathrm{F}$. Temperatures less than $32^{\circ} \mathrm{F}$ occur on an average of 25 days each year.

Long-term precipitation records collected by the National Weather Service at the Austin Municipal Airport have been summarized by Brune and Duffin (1983, p. 8). According to these records, the mean annual precipitation for this station is about $32 \mathrm{in}$. These long-term records indicate that precipitation is fairly evenly distributed throughout the year; however, locally large storms usually occur during April-May and September-0ctober. The precipitation at the Austin Weather Service Station during the study period was 54.68 in., of which 37.82 in. occurred during the first 13 months and 16.86 in. occurred during the 1 ast 12 months. All of the precipitation for the storms analyzed in this report is rainfall.

\section{Acknowl edgments}

The authors wish to thank the personnel of the Watershed Management Section of the city of Austin Public Works Department for their help in obtaining engineering records of the study areas, the management of the Barton Creek Square Shopping Center, and the property owners association of Alta Vista Planned Unit Development for allowing access to their 1 and.

The authors gratefully acknowledge the assistance given by $H$. B. Mendieta in the collection of field data; Emma M. McPherson and personnel in the Texas District Water-Qual ity Unit for their assistance in the determination of analytical data; E. T. Baker, Jr., for his description of the geology of the study areas; and Raymond M. Siade, Jr. for his assistance in designing the gage and computing the discharge data.

\section{DESCRIPTION OF BARTON CREEK SQUARE SHOPPING CENTER WATERSHED}

The buildings and parking lot of Barton Creek Square Shopping Center occupy about 100 acres. Most runoff from the mall flows into three detention and filtering ponds around the perimeter of the shopping mall. Pond 1, selected for this study, drains about 46 acres from the mall plus an additional 33.5 acres adjacent to the mall (fig. 2). The watershed of Pond 1 is divided into four sections (A-D) on the basis of 1 and use and drainage system (fig. 2).

Section A drains 46 acres from the northeastern part of the mall. About 86 percent (39.6 acres) of this area consists of impervious cover from roof tops, parking lots, and roads. The pervious area in section A covers 6.4 acres and consists of flower beds and grass. Drainage inlets are located along the roads and throughout the parking area; these drains, along with drains from rooftops, connect to a 72-in. diameter concrete pipe that delivers runoff to detention Pond 1 . All of the runoff from section $A$ is gaged at a monitoring site at the downsteam end of the pipe. Land-surface altitudes in 

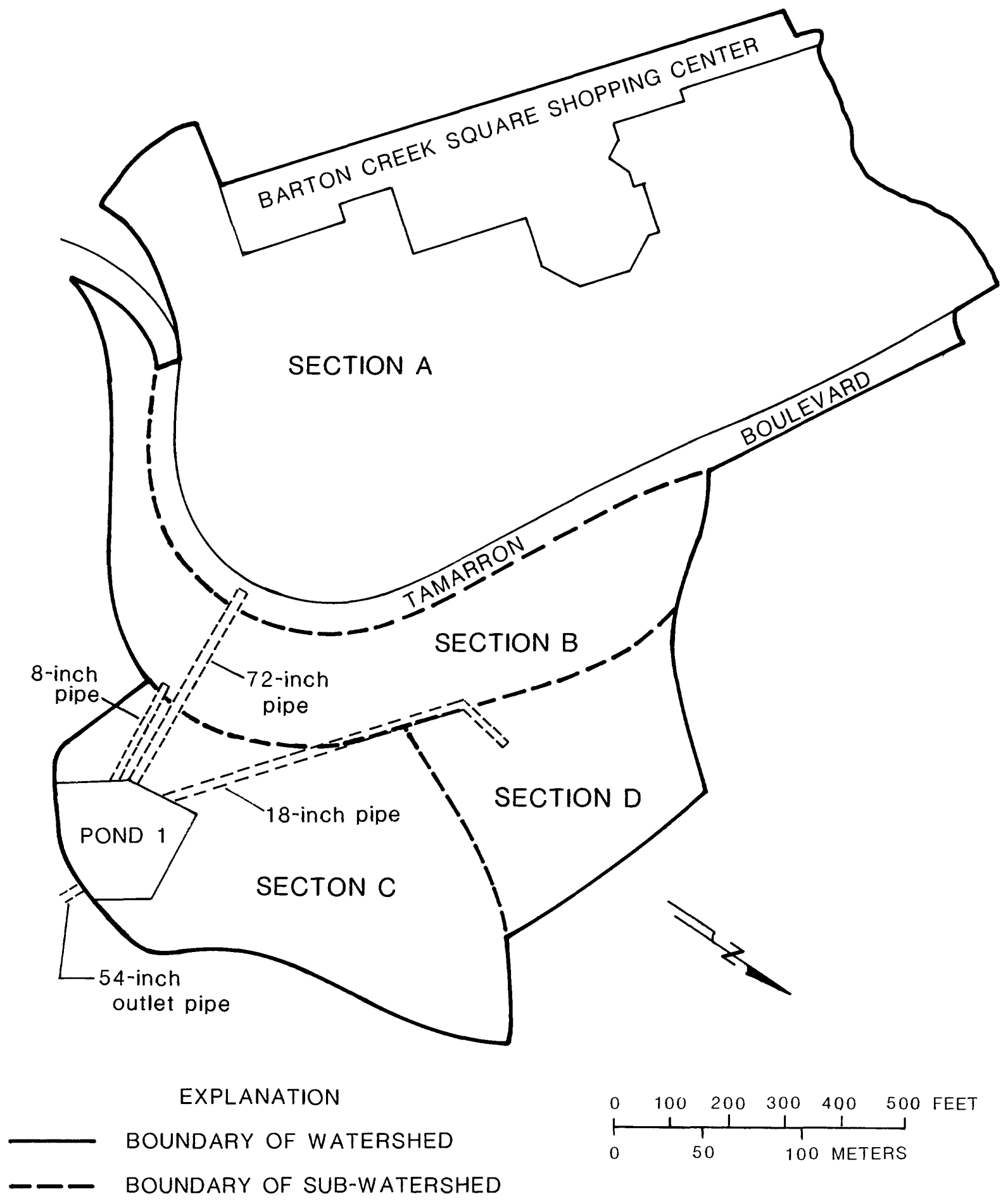

Figure 2.--Watershed of Pond 1 at Barton Creek Square Shopping Center. 
section A range from about 763 to $685 \mathrm{ft}$ above National Geodetic Vertical Datum of 1929 (NGVD of 1929). Most of the inflow to Pond 1, herein named Skunk Hollow Creek by the U.S. Geological Survey, is from section A.

Section B drains approximately 13 acres of mostly unvegetated caliche soil. Prior to February 1983, runoff from section B bypassed Pond 1. In February 1983, an 8-in. plastic pipe was installed to divert most of the runoff from this area directly into Pond 1. Runoff from this section is not gaged. Land-surface altitudes in section $B$ range from about 740 to $680 \mathrm{ft}$ above NGVD of 1929.

Section C, which drains about 12 acres, contains Pond 1, a wooded area, and a small section of single-family residential homes. The perimeter of Pond 1 is vegetated with grasses. Runoff from section $C$ is not gaged and flows into Pond 1 as overland flow. Ninety-eight percent of section $C$ is pervious, and altitudes range from about $700 \mathrm{ft}$ within the section to $596 \mathrm{ft}$ at the bottom of the pond.

Section D drains approximately 8.5 acres from a residential development and an undeveloped wooded area. Approximately 25 percent of section D consists of impervious roof tops, driveways, and paved streets. The pervious area in section $D$ consists of grasses, flower beds, 1 ive oaks, and junipers. Runoff from the residential area flows through a drainage channel to a grated inlet for an 18-in. concrete pipe which discharges into the pond. The invert of the inlet is el evated above the surrounding 1 and surface, so that approximately the first inch of runoff is stored within the area. Thus, little of the runoff from section $D$ enters the pond. Runoff from section $D$ is not gaged.

Pond 1, with a storage capacity of approximately 3.5 acre-ft, is about 270-ft wide, 320-ft long, and a 14-ft maximum depth. The bed of the pond consists of three layers of material that are used to filter water in the pond (fig. 3). The top layer is $18 \mathrm{in}$. of fine sand, the middle 1 ayer is $12 \mathrm{in}$. of coarse sand, and the bottom layer is $6 \mathrm{in}$. of gravel. Water percolates through these 1 ayers and drains into 6-in. perforated pipes. The pipes route the water to the outlet structure where the discharge is measured with a V-notch weir. Bel ow the 6-in. perforated pipes are 3 in. of gravel and a 24-in. clay liner. The filter bed covers about 85 percent of floor of the pond with the remaining cover being natural soil. A photograph of the pond that shows the inflow structure (foreground) and outflow structure (background) is in figure 4 .

Runoff from Barton Creek Square Shopping Center enters the detention pond through a 72-in. concrete pipe; runoff from the conservation easement enters the pond through separate pipes or as overland flow. Flow from the 72-in. concrete pipe enters the pond through an inflow control structure (fig. 5). The structure is $15 \mathrm{ft}$ wide and about $34 \mathrm{ft}$ 10ng. A weir that is $15 \mathrm{ft}$ long by $6 \mathrm{ft}$ high was $\mathrm{pl}$ aced across the inflow control structure at about $25 \mathrm{ft}$ from the outlet of the 72-in. pipe to measure water discharge.

The outflow control structure is similar to the inflow structure. Flow is gaged by a 12-ft by 4-ft V-notch weir. The gaging shelters are located on the right wing wall of the structure (fig. 4). 


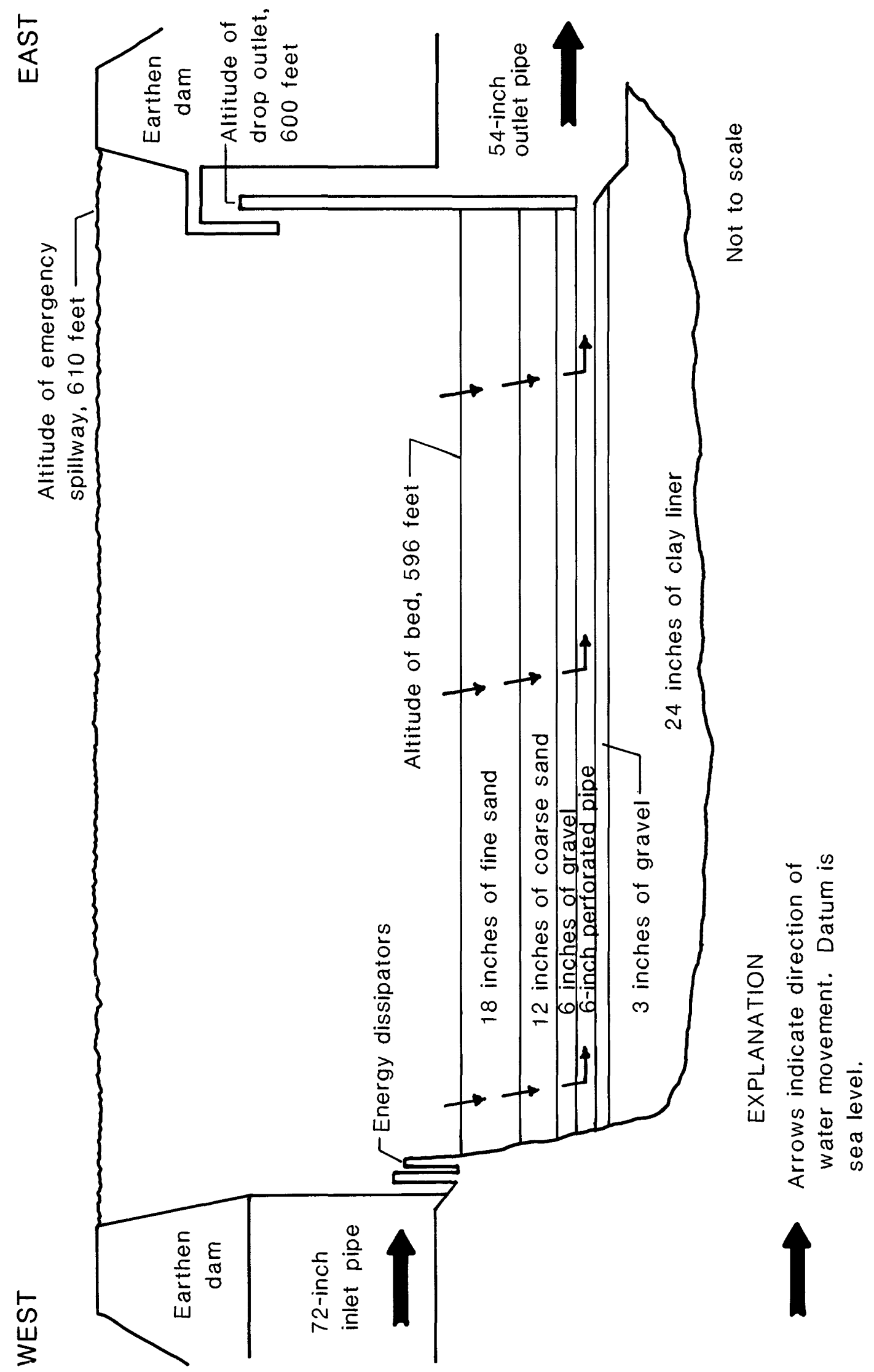

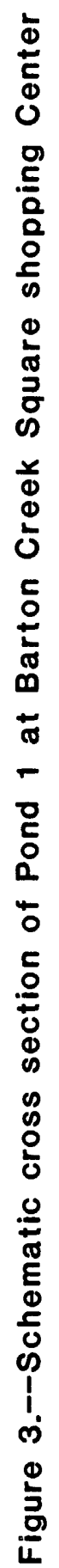




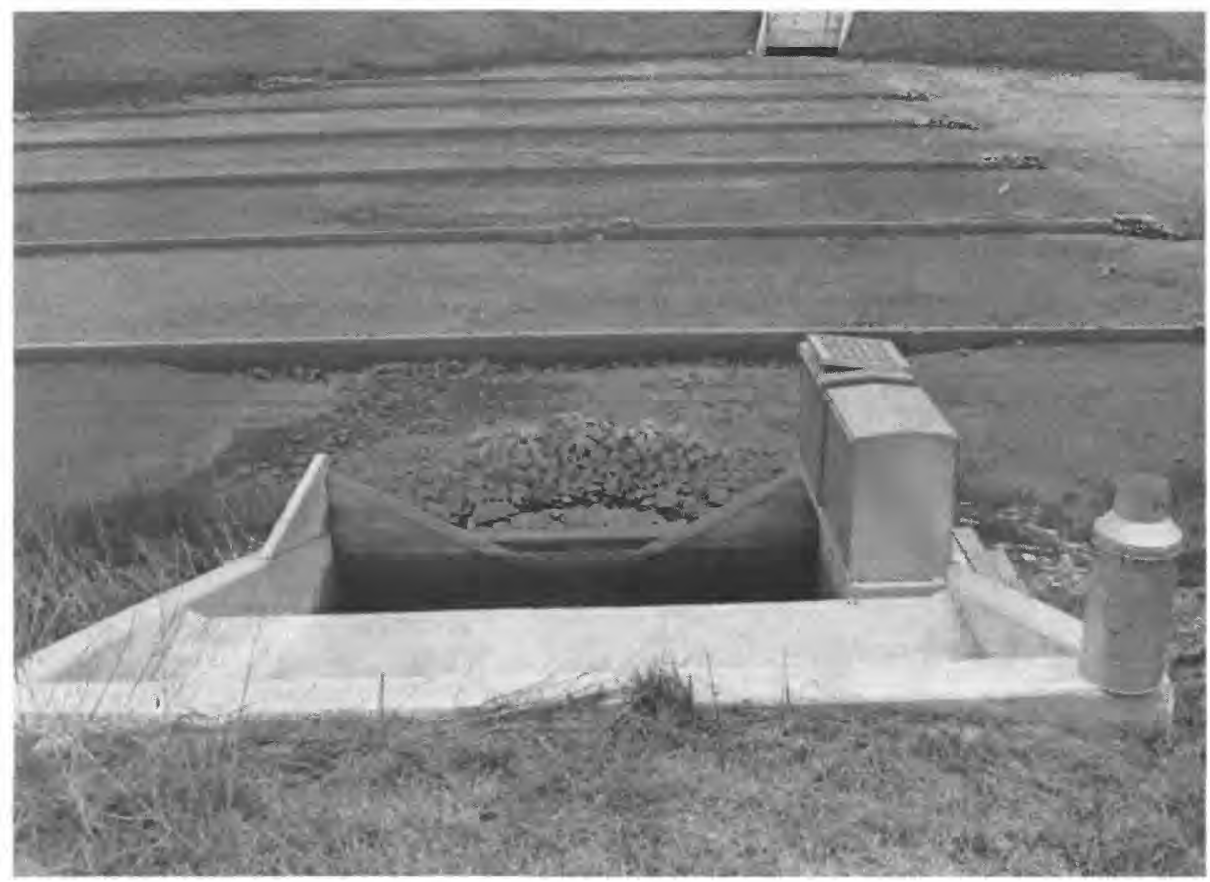

A. Pond 1 at Barton Creek Square Shopping Center

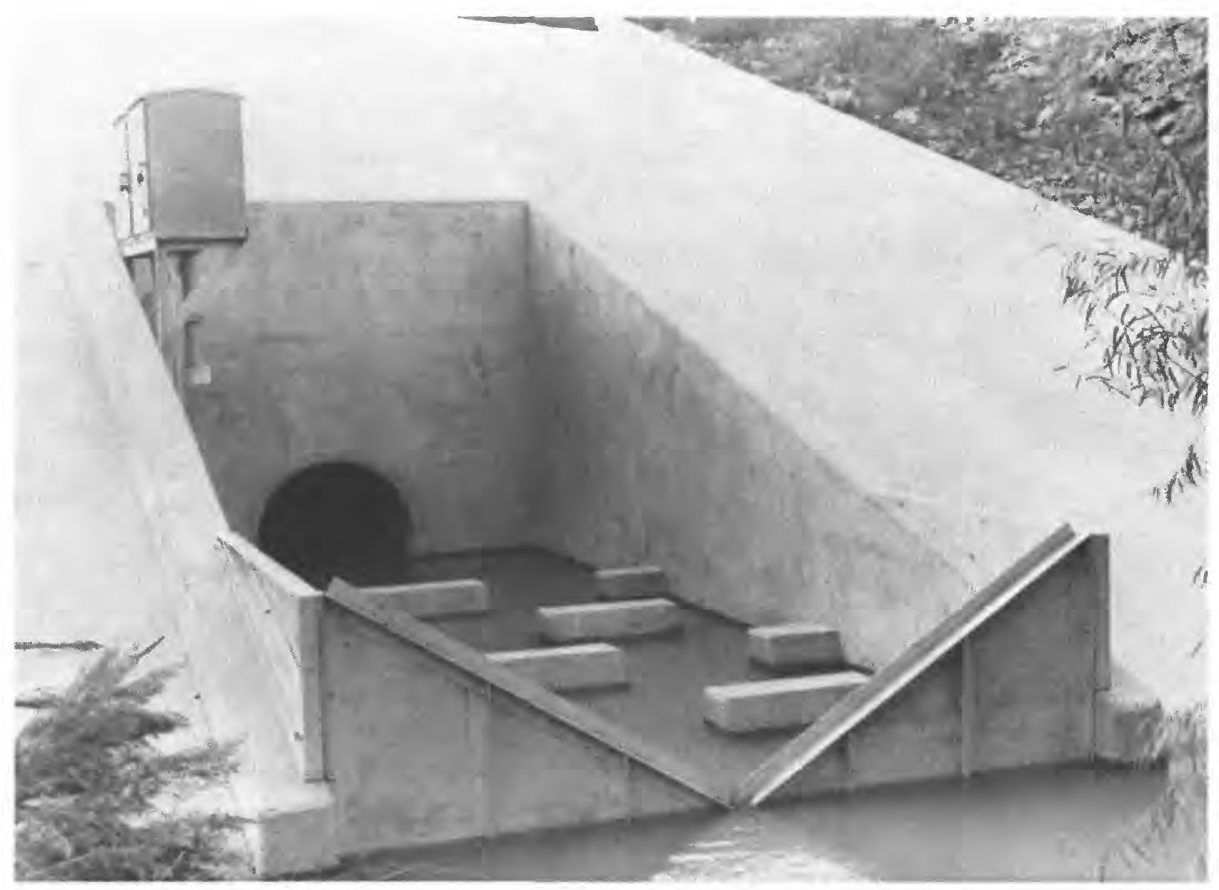

B. Outflow control structure for Pond 1 at Barton Creek Square Shopping Center

Figure 4.--Pond 1 at Barton Creek Square Shopping Center and outflow control structure. 


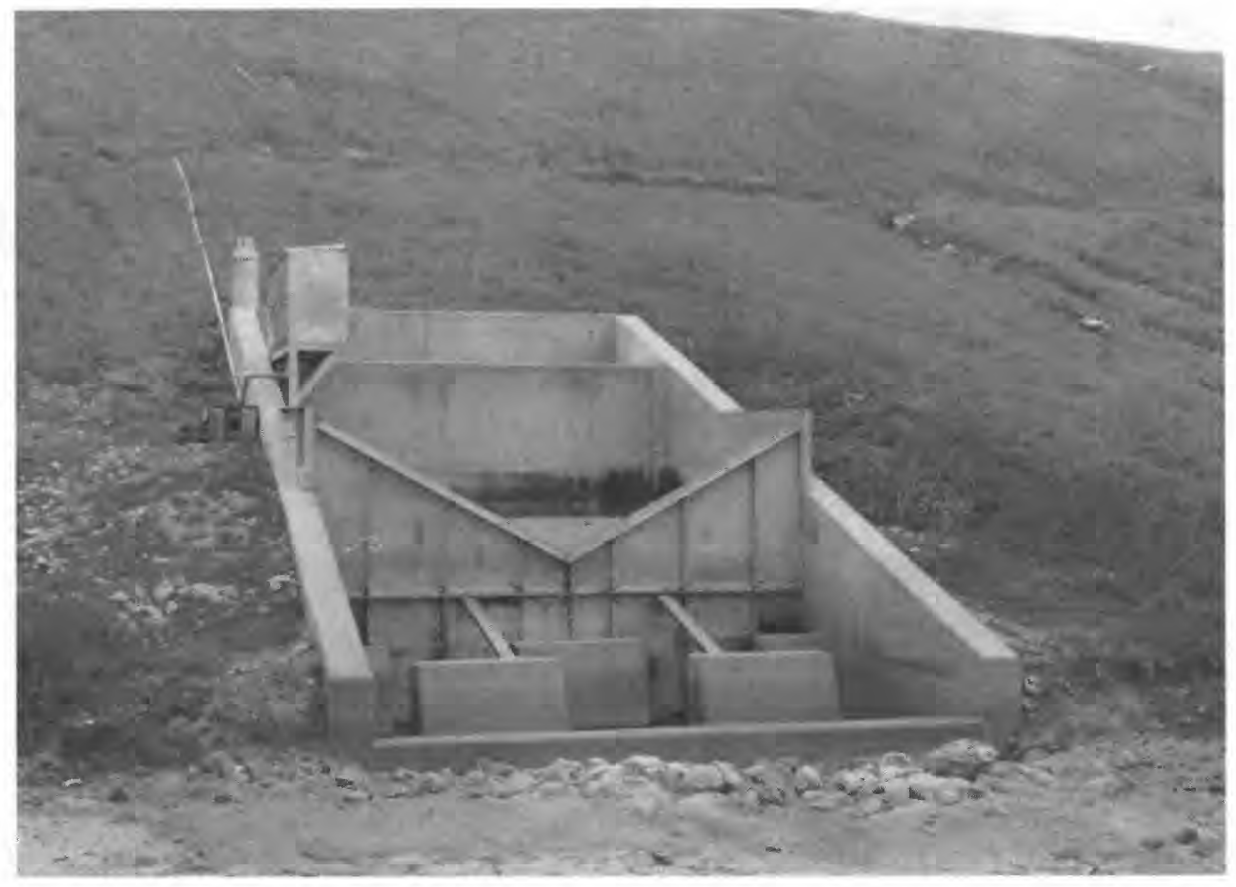

A. Oblique view of control structure

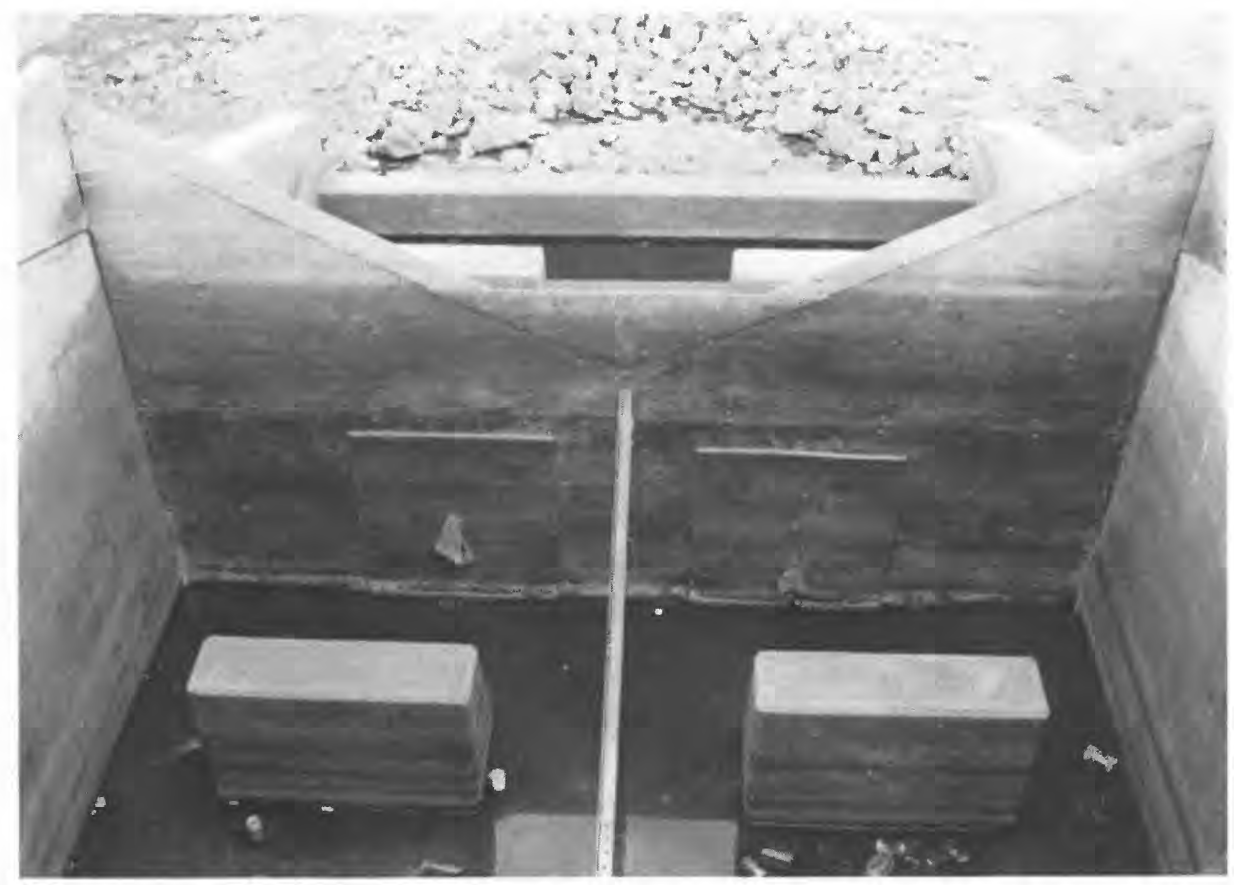

B. Top view of control structure

Figure 5.--Inflow control structure for Pond 1 at Barton Creek Square Shopping Center. 
Several extensively faulted geologic formations of cretaceous age are exposed in the area. The Edwards and overlying Georgetown Limestones, which form the Edwards aquifer, and the overlying Del Rio Clay and Buda Limestone crop out within a few hundred feet of Pond 1. The geology of this area is taken from Rodda and others (1970). Pond 1 is located almost totally on an upthrown-faulted block of the Georgetown Limestone. A northeast-trending fault with an estimated vertical displacement of at least $80 \mathrm{ft}$ in places cuts the northwest corner of the pond. Across this fault at the pond, the Del Rio $\mathrm{Cl}$ ay, a relatively impermeable confining bed, is in contact with the Georgetown Limestone. The Edwards Limestone and Georgetown Limestone, both of which constitute the Edwards aquifer in this area, are on opposite sides of the fault in the drainage channel that receives outflow from the pond. The tributary channel drains to Barton Creek $0.5 \mathrm{mi}$ downstream. Throughout this distance, the Edwards Limestone remains exposed in the channel, which is cut by several additional faults.

The natural 1 and use suitability of the Georgetown Limestone, which contains the detention pond, is unsatisfactory according to Garner and Young (1976) with respect to waste disposal in unlined 1 iquid-waste retention ponds and with respect to water storage in unl ined reservoirs and ponds.

\section{DESCRIPTION OF ALTA VISTA PLANNED UNIT DEVELOPMENT WATERSHED}

The Alta Vista Planned Unit Development covers 1ess than 4 acres in northwest Austin (fig. 6). The entire drainage area consists of medium-density townhouses; there are 19 townhouses and 1 small recreation area with a swimming pool. Approximately 62 percent of the surface area consists of impervious cover from rooftops, driveways, and paved streets. The remaining area is covered mostly with grass and flower beds. Land-surface altitudes average about $885 \mathrm{ft}$ above NGVD of 1929 at Adirondack Trail. Alta Vista is drained by grass channels along the east and west side of the basin. The drainage channels are herein named Mayfield Creek by the U.S. Geological Survey. The gaging station on Mayfield Creek at Alta Verde Drive is considered to be the inflow station for the east channel. The western channel is ungaged upstream from the detention area. The gaging station on Mayfield Creek at Steck Avenue is the outflow station for the runoff controls (fig. 6).

The drainage area of the east channel, upstream from the gaging station at Alta Vista Drive, is 0.7 acre. The drainage area for the Mayfield Creek at the Steck gaging station varies from 1.63 to 2.88 acres. Depending upon the rainfall rate, runoff from the west channel overflows the drainage boundaries, resulting in a variable outflow drainage area.

The inflow station measures runoff that flows down a grass-covered swale and is channeled through an 18-in. pipe culvert, and immediately downstream from Alta Verde Drive, the flow is measured over a V-notch weir (fig. 7 ). Runoff continues from the weir down a grass-covered swale before it enters the detention area (fig. 7). Figure 8 shows the detention area and the outflow gaging station and figure 8 shows the grass swale on the west ungaged channel. The west ungaged channel ends at the detention area and gaging station (fig. 8). 


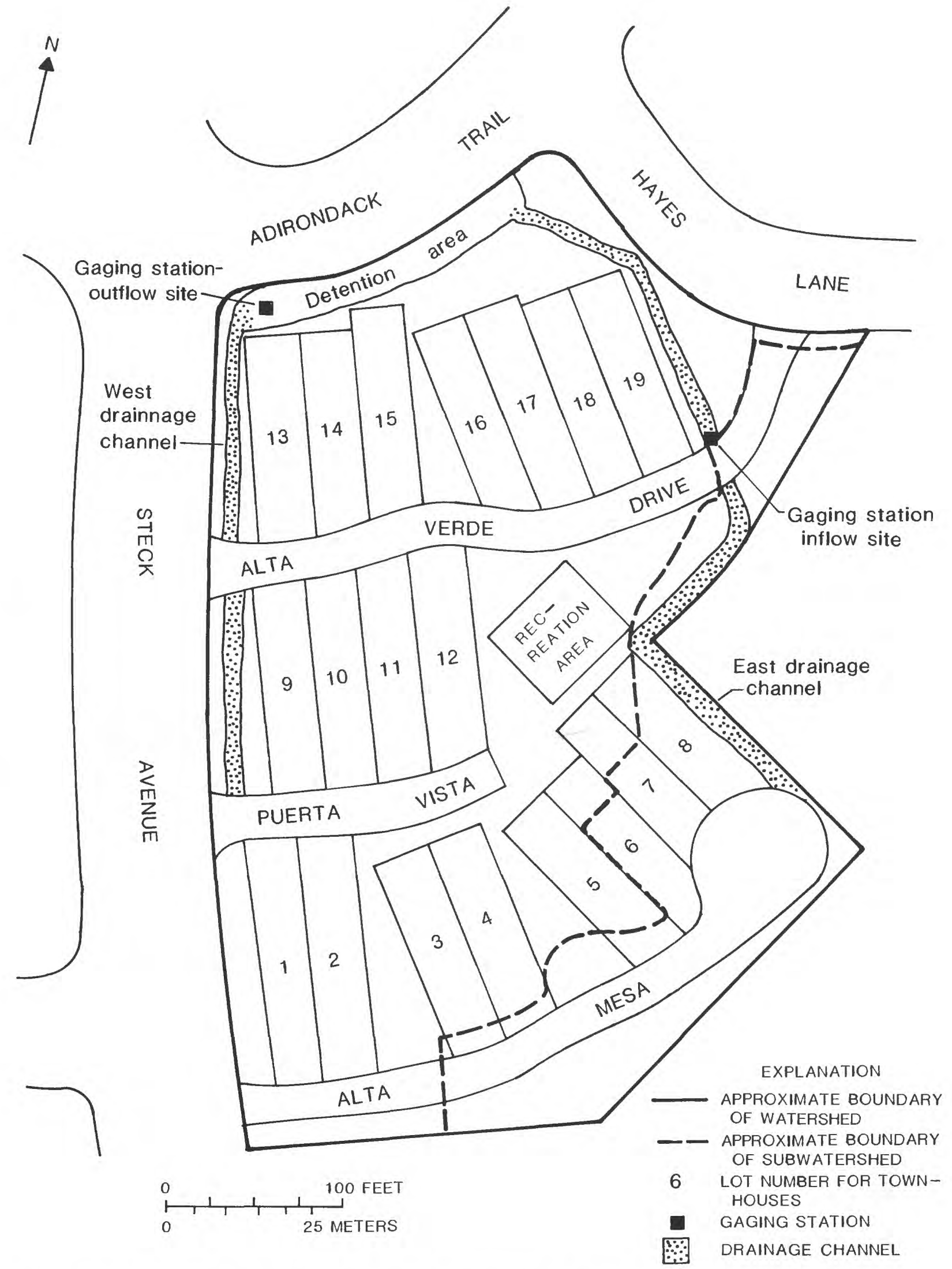

Figure 6.--Watershed of the Alta Vista Planned Unit Development. 

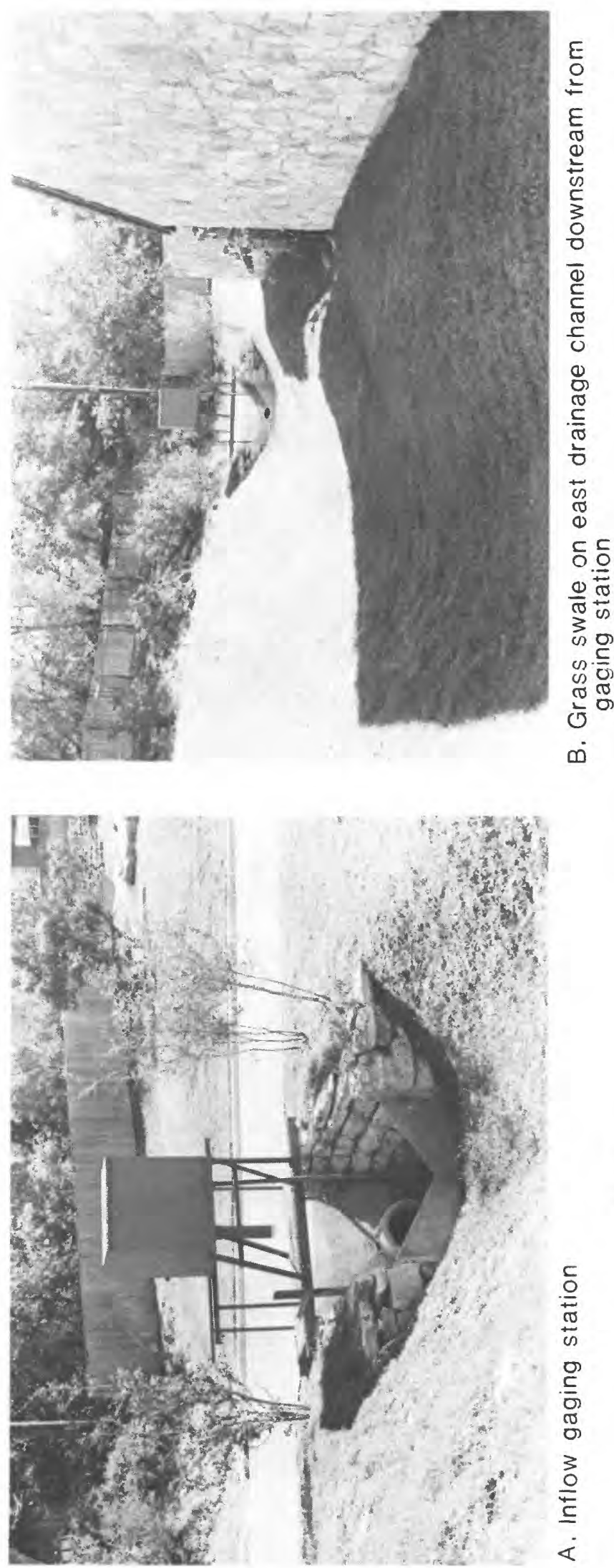

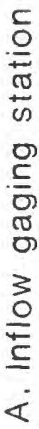

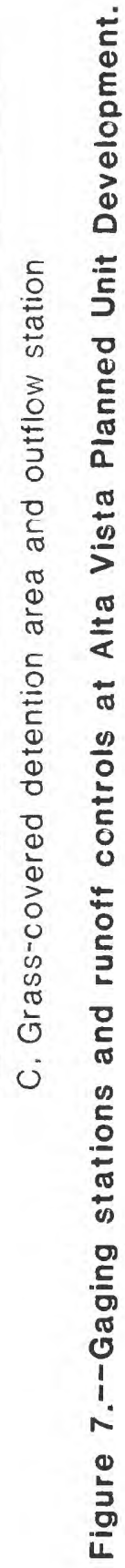




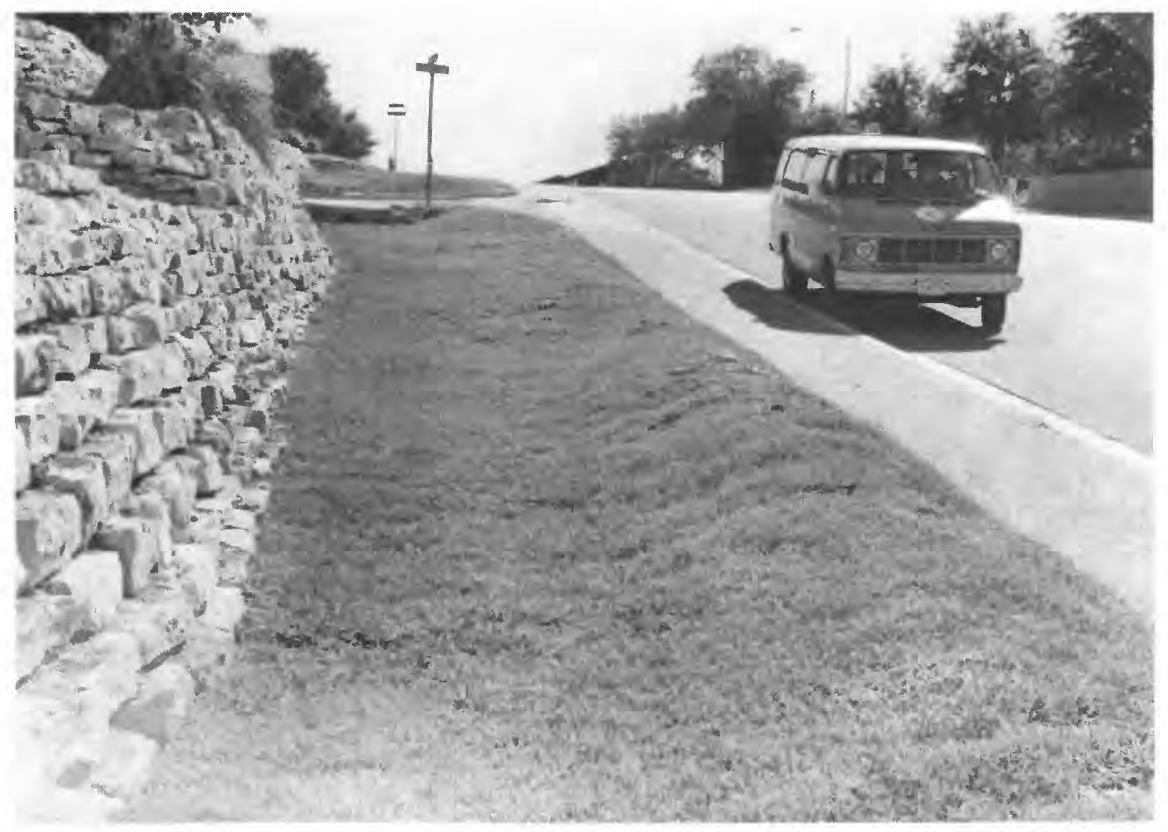

A. Grass swale on west drainage channel

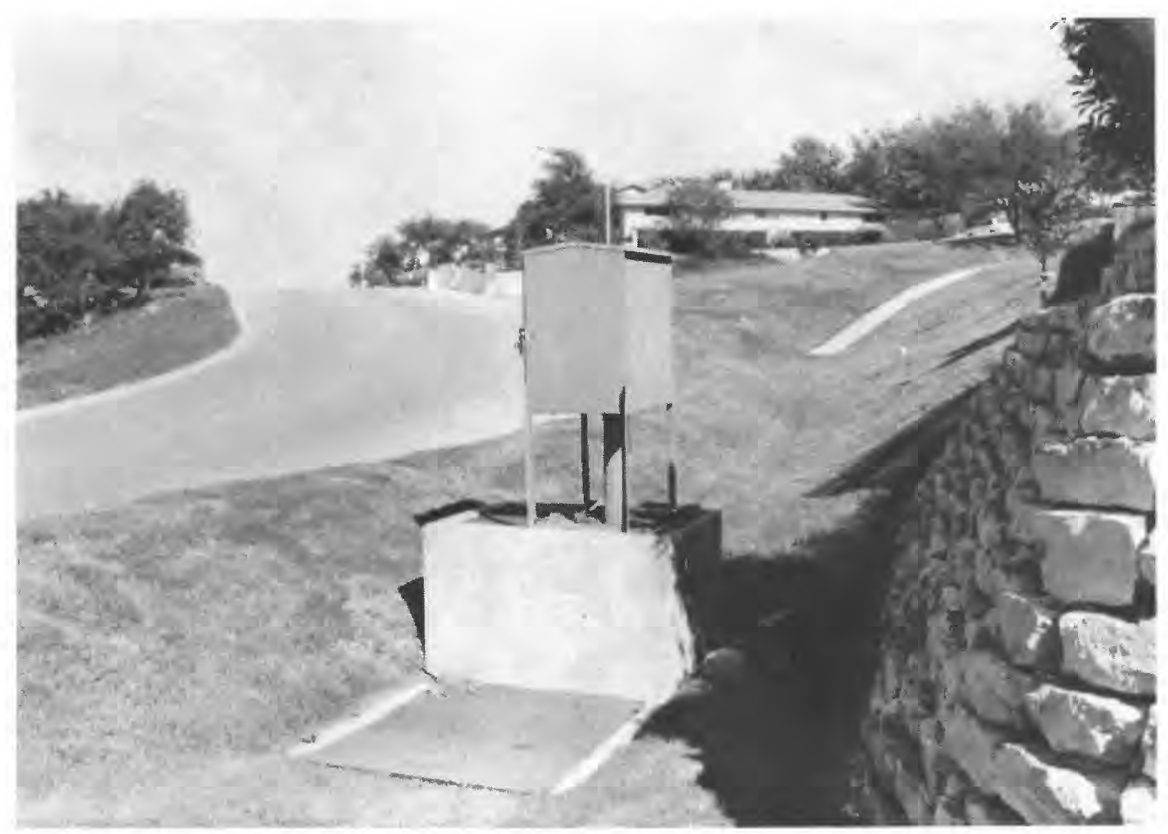

B. Detention pond and outflow gaging station on the drop outlet 
Drainage from the detention area is through a drop outlet, $2.5 \mathrm{ft}$ wide and $6 \mathrm{ft}$ deep, and is connected to an 18-in. pipe culvert. A filter drain, composed of 0.05 - to $1.0-i n$. rocks in the low end of the detention area, allows small flows to drain directly into the drop-outlet structure. Extremely large flows top the crest of the drop outlet and spill into the structure. Intermediate flows are detained in the detention area and are gradually rel eased through the filter drain. The outflow gaging station is mounted on the drop outlet. A flat, sharp-crested weir across the 18-in. pipe allows small flows to be computed from the stage record and a theoretical rating. When the 18-in. pipe becomes submerged, the flow is computed by using an orifice equation. A rectangular weir is placed across the 18-in. pipe in the bottom of the outlet so that the water surface $c$ an be measured by a stage recorder. Flow from the 18-in. pipe discharges to a tributary of Bull Creek.

The geology for this site was taken from Garner and Young (1976). The contributing drainage to the site is contained on the outcrop of the Cretaceous Edwards Limestone. Specifically, the site is on the lowest member of the Edwards Limestone--member 1--as subdivided by Rodda and others (1970). The Alta Vista site is not affected by faulting; the nearest fault is 1 mi to the east.

The natural land use suitability of the Edwards Limestone has been summarized by Garner and Young (1976). With respect to waste disposal in unl ined liquid-waste retention ponds and with respect to water storage in unlined reservoirs and ponds, Garner and Young (1976) judged the Edwards Limestone to be unsatisfactory.

\section{DATA AVAILABILITY AND COLLECTION}

Instruments were installed at each study area to record rainfall and stage and to collect water-quality samples. One recording rain gage was installed at each area and was serviced and operated by personnel of the city of Austin. The quantity and quality of runoff was collected at stations immediately upstream and downstream of the control structures and are referred to as inflow and outflow stations for the runoff controls. A Manning UT " $X$ " System Level Transmitter and Recorder $1 /$ was used at the inflow and outflow stations to measure stage. A stage-discharge relation was developed for each inflow and outflow station to compute discharge.

Manning S-4050 automatic water samplers were used to collect samples of storm runoff at the inflow and outflow stations from each area. The sampler intake was located near the bottom of the channel and was activated when the stage rose to a predetermined level. The level was set low enough to sample the first flush of stormwater runoff. In this study, the automatic sampler generally was set to collect two 1-liter bottles per sampling interval. The sampler is self-purging and the vacuum lines and sampler chamber are flushed with stormwater immediately prior to the collection of each sample.

1/ Use of trade names in this report is for identification purposes only and does not constitute endorsement by the U.S. Geological Survey. 
At the BCSSC area, two automatic water samplers were installed at each station, whereas at the Alta Vista area only one automatic sampler was installed at each station. One automatic sampler at the BCSSC inflow station was set to collect samples at 7.5-minute intervals and the second sampler was set to collect samples at 30-minute intervals. At the BCSSC outflow station, one sampler was set to collect samples at 15-minute intervals, whereas the second sampler was set at 2-hour intervals. The samplers at the Alta Vista inflow and outflow stations were set at 7.5-minute intervals. The sampling intervals at each location allowed for samples to be collected during periods of longest flow and for long durations.

Storms generally were selected for analysis if there had been no runoff for a week or more; however, some storms were selected for analysis with less time since the previous storm because of varying rainfall patterns. Data from 22 storms at BCSSC and 19 storms at Al ta Vista were collected and analyzed. The storms selected for analysis produced from a few tenths to several inches of runoff.

Rainfall volumes and maximum rainfall intensities for selected time intervals were computed. The amount of runoff that resulted from the rainfall was computed at the inflow and outflow stations at the BCSSC area. Runoff at the outflow station at the Alta Vista area could not be determined because of inconsistent records and because of an indefinite contributing drainage area. At the BCSSC area, differences in peak discharges were compared to determine the effectiveness of the control structures on reducing peak discharges; comparison of volumes at the inflow and outflow stations al so were compared to determine the effectiveness of the runoff controls at reducing total runoff.

Most of the water samples were collected by automatic water samplers; however, supplemental water samples were collected by field personnel from both the gaged and ungaged areas at the BCSSC area on several occasions. A discharge-weighted composite water sample was analyzed at the inflow and outflow stations for each storm event at both study areas. Discharge-weighted concentrations represent the concentration of the constituent if all the water flowing past the sampling location were collected and thoroughly mixed. Discharge-weighted concentrations for each inflow and outflow station were compared to determine if the quality of the water was influenced by the runoff controls. Discharge-weighted concentrations al so were used in the computation of total loads. Differences in load data were used to compute removal efficiencies at BCSSC. Load data could not be computed at Alta Vista because of inaccuracies in discharge data.

In addition to the discharge-weighted composite samples, four discrete water samples were collected at the inflow and outflow stations during six storms at BCSSC and during five storms at Alta Vista. Data from these discrete samples were used to determine if peak concentrations of chemical constituents or densities of indication bacteria had been reduced by the runoff controls.

Discrete and the discharge-weighted composite water samples were analyzed for specific conductance, fecal-coliform and fecal-streptococci bacteria, suspended solids, dissolved solids, volatile dissolved solids, biochemical oxygen 
demand (BOD), chemical oxygen demand (COD), total organic carbon (TOC), total nitrogen (total organic nitrogen plus total ammonia nitrogen and total nitrite nitrogen plus total nitrate nitrogen), total phosphorus, dissolved cadmium, dissolved lead, dissolved iron, and dissolved zinc. Analyses were performed according to methods outlined by Guy (1969); Skougstad and others (1979); and by Wershaw and others (1983).

\section{EFFECTS OF RUNOFF CONTROLS AT BARTON CREEK SQUARE SHOPPING CENTER}

\section{Rainfall-Runoff Characteristics}

A summary of the rainfall-runoff characteristics for all 22 storms is presented in table 1. Total rainfall for the selected storms ranged from 0.14 to $2.88 \mathrm{in}$. The maximum 5-minute interval ranged from 0.02 to $1.30 \mathrm{in}$. The two storms with the highest 5-minute rainfall occurred on August 8 and September 7, 1983. Rainfall during the August 8, 1983, storm had maximum 5-, 10-, and 15-minute accumulations approximately equal to that of a 50-year recurrence interval. Maximum rainfall during the September 7 storm was greater than the 100-year reccurrence interval for the 5- and 10-minute durations and equal to the 50-year recurrence interval for the 15-minute duration as determined in a rainfall frequency study in Austin by Carter (1975). Austin area rainfall for selected recurrence intervals as determined by Carter (1975) are tabulated as follows:

\begin{tabular}{lrcc}
\hline \multirow{2}{*}{$\begin{array}{l}\text { Duration } \\
\text { (minutes) }\end{array}$} & \multicolumn{3}{c}{$\begin{array}{c}\text { Rainfal1, in inches, for } \\
\text { recurrence intervals of: }\end{array}$} \\
\hline \multirow{2}{*}{5} & 0.54 & 50 years & 100 years \\
10 & .87 & 0.91 & 0.99 \\
15 & 1.15 & 1.51 & 1.67 \\
& & 1.96 & 2.15 \\
\hline
\end{tabular}

Analyses of storms involved compiling the rainfall and runoff data and preparing graphs to display the information. For 22 selected storms, the 5-minute incremental rainfall is shown above the discharge hydrographs for the inflow and outflow stations in figures 9-14. From these graphs, rainfall quantities and intensities can be compared to discharge rates and volumes.

The peak discharge for a particular watershed usually is highly dependent on the maximum rainfall intensity for a duration equal to that watershed's time of concentration. The time of concentration usually is defined as the time required for water to flow from the most remote point in a drainage basin (or subsection) to its outlet. For the inflow station, the peak discharge appeared to be 1 argely a function of maximum 5-minute rainfall rate and, as expected, the storms with the three 1 argest maximum 5-minute rainfalls had the 1 argest maximum peak discharges. The storms of 0ctober 28, 1982, August 8, 1983, and September 7, 1983, had peak discharges of 171,185 , and $185 \mathrm{ft} 3 / \mathrm{s}$, and their respective maximum 5 -minute rainfalls were $0.40,0.90$, and 1.30 in . The maximum peak discharges at the inflow site are 1 imited to $185 \mathrm{ft}^{3} / \mathrm{s}$ 

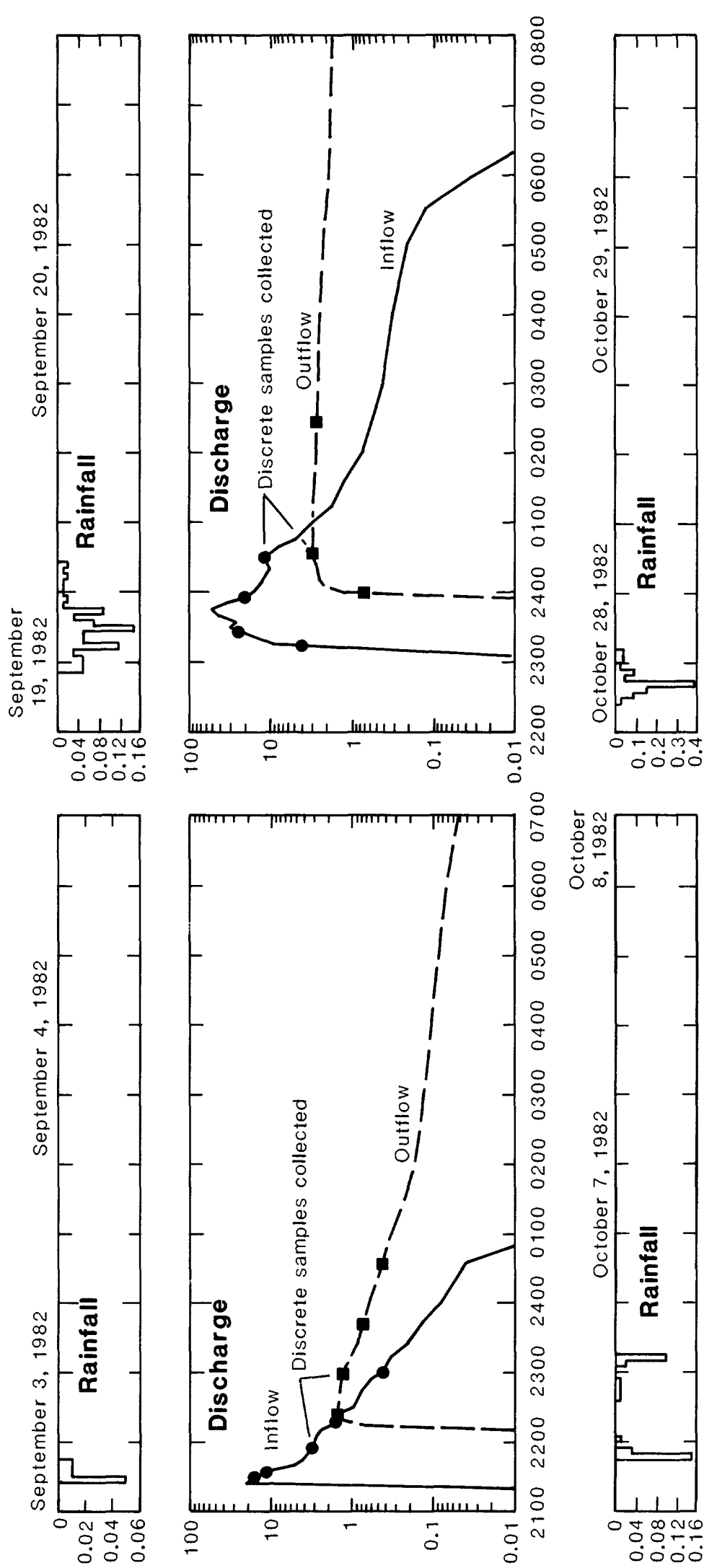

SFHONI NI

'ㄱ $\forall$ JNIVY

aNOO $\exists S$ y

'כэy
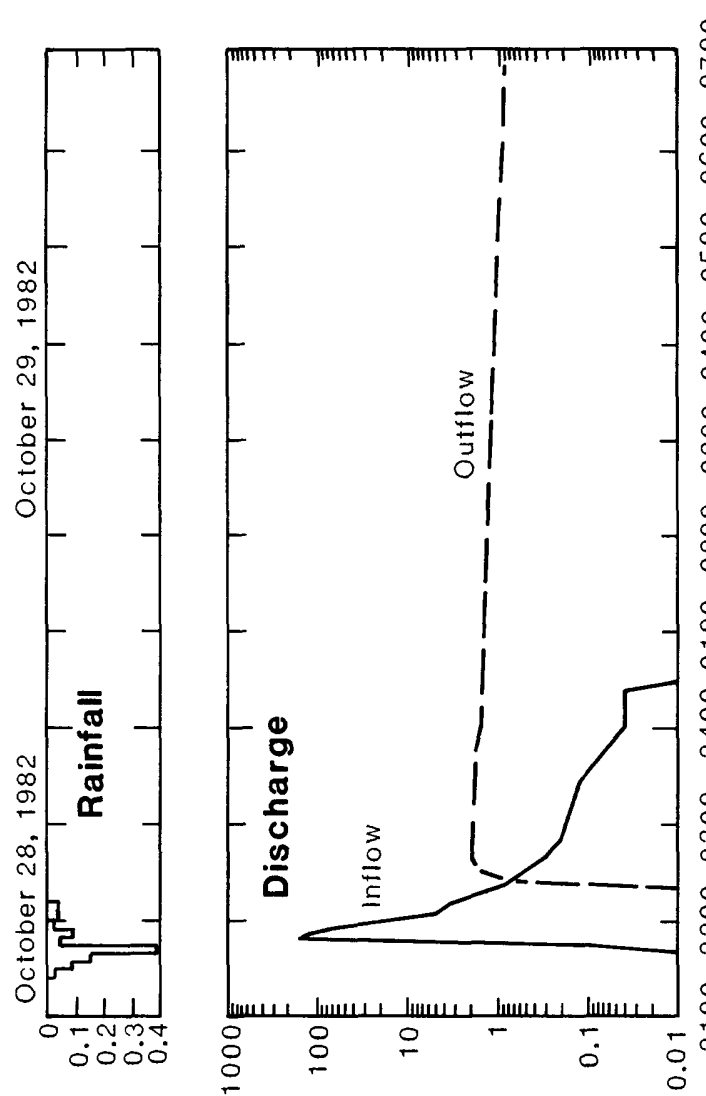

$\stackrel{2}{ \pm}$

$\leftarrow$

(2) ?

인

혹

ㅎํ

ธิ

은

동

๘

응 흥

更

웡

을

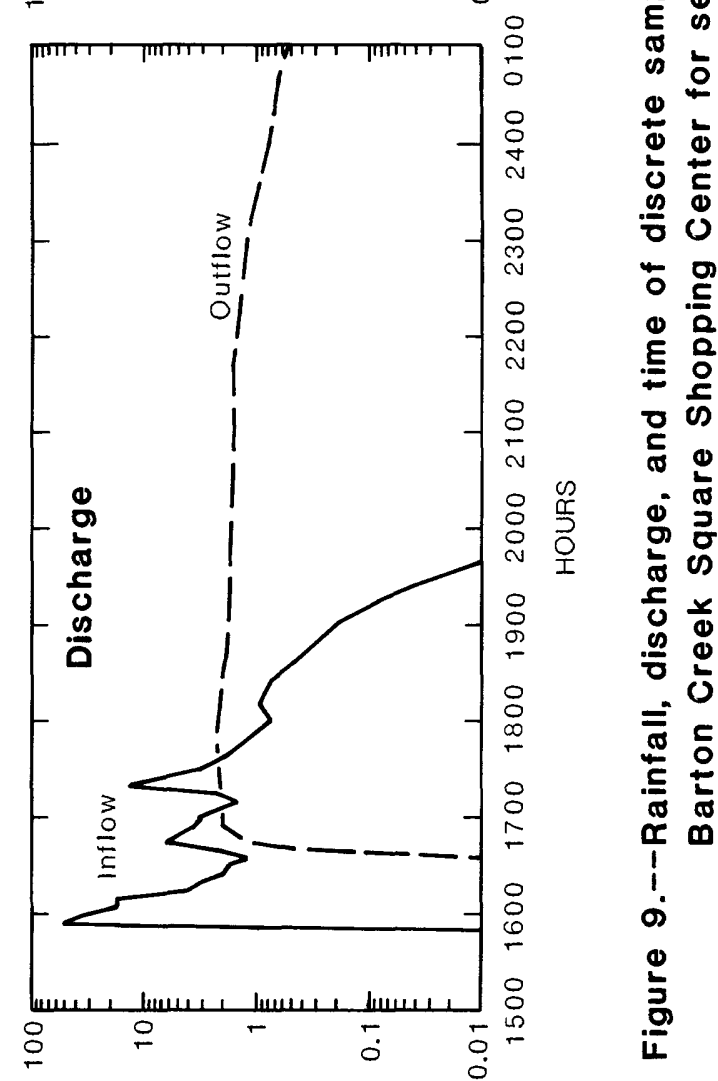

SFHONI NI

'רา $\forall J N I \forall Y$
aNOJ $\exists S$ Y

'э⿹\zh13一HOSIO 

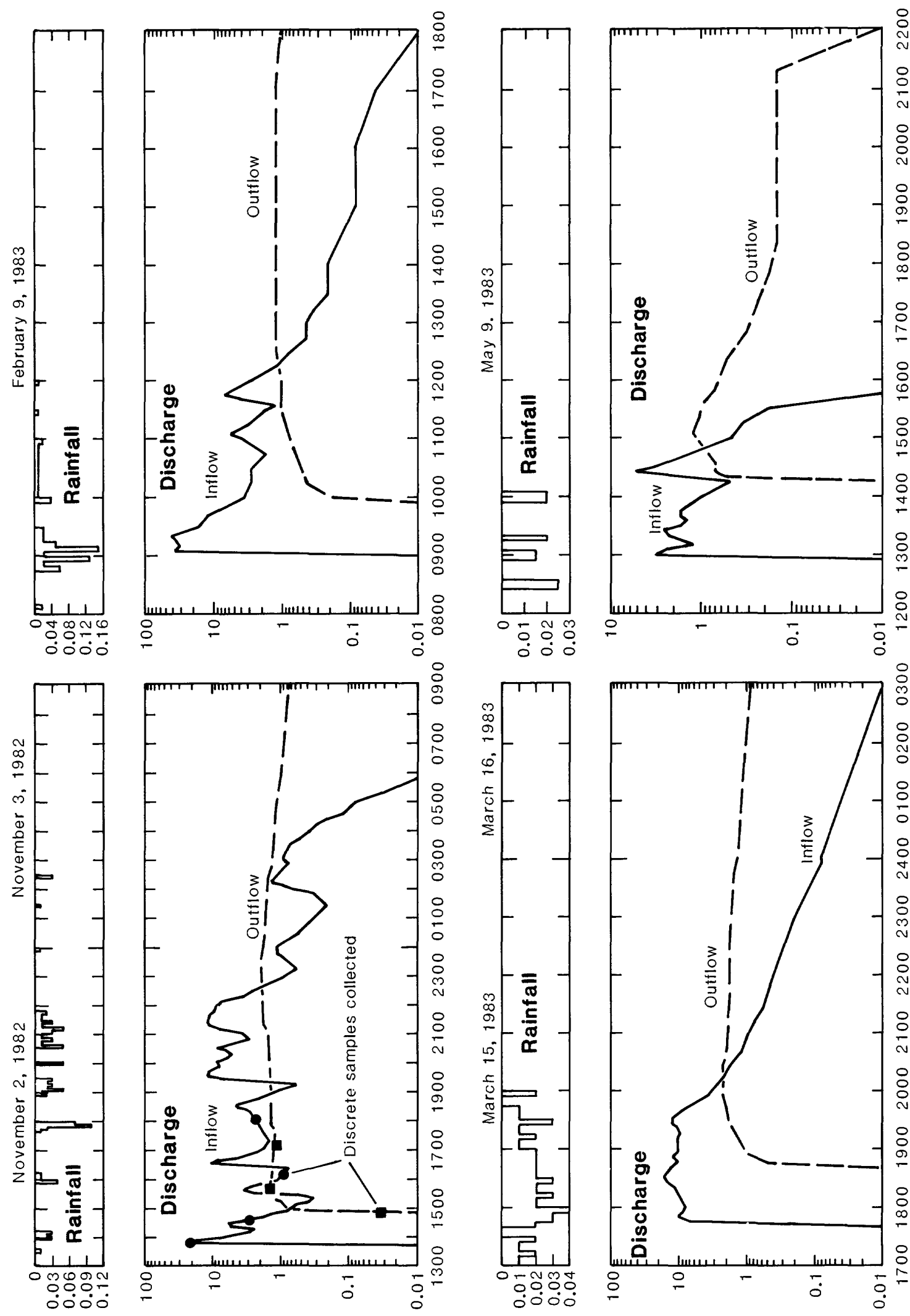

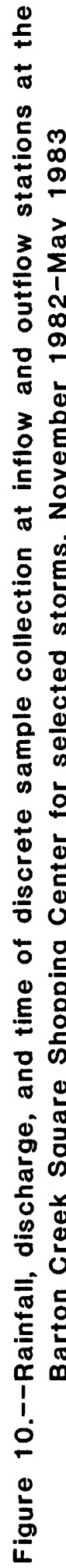

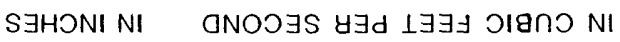

'า7 $\forall J N I \forall Y$ ' $\exists$ gy

SFHONI NI '77ษ INIVY
ONOO $\exists S$ Y ' $\exists$ Y Y HOSIO 

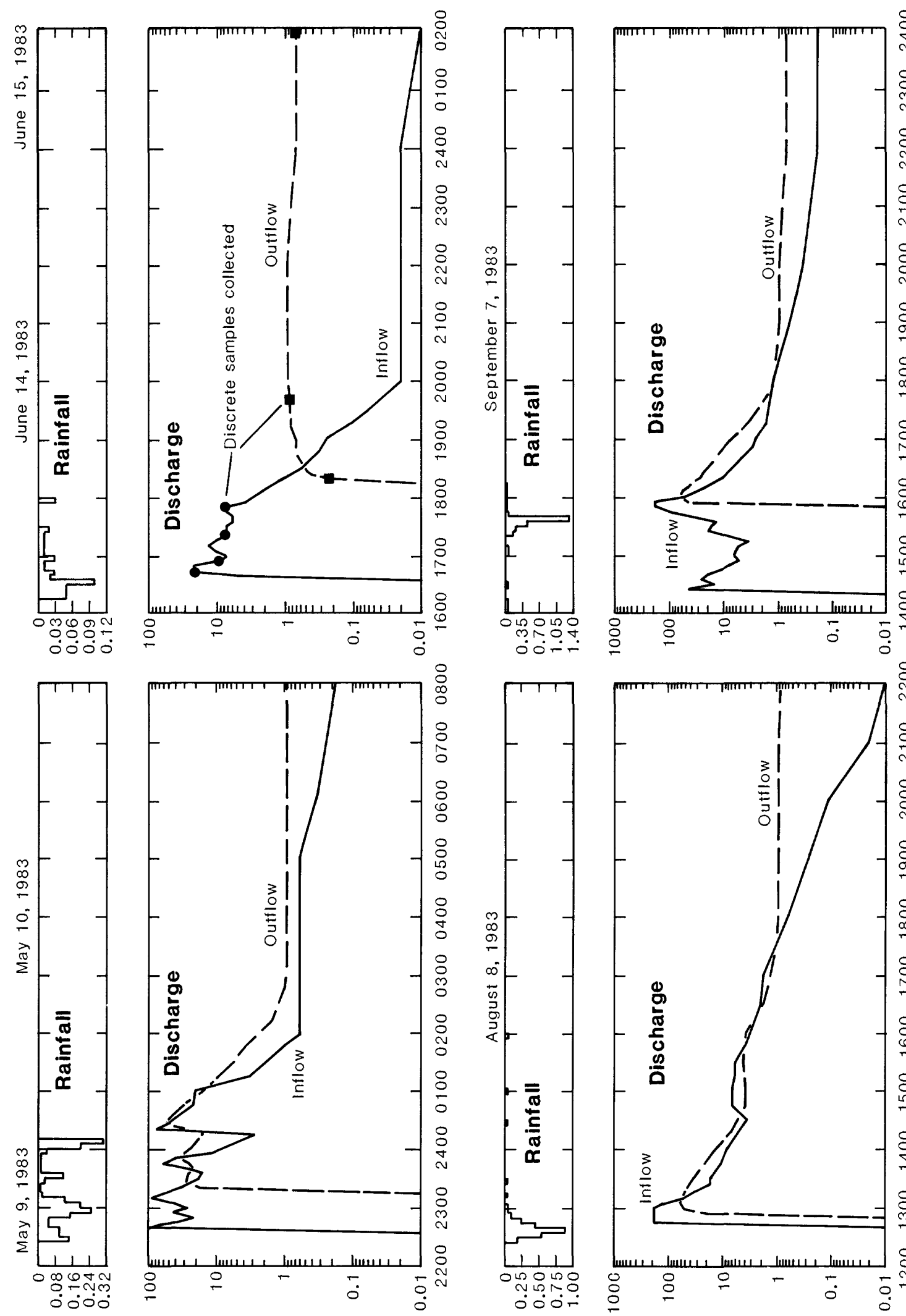

SЭHONI NI aNOO $\exists$ S 4 d $1 \exists \exists \exists$ JIQRO NI

$' 77 \forall J N I \forall Y$

' $\exists$ Y $\forall$ HOSIO

SЭHONI NI

'7า JNIVY

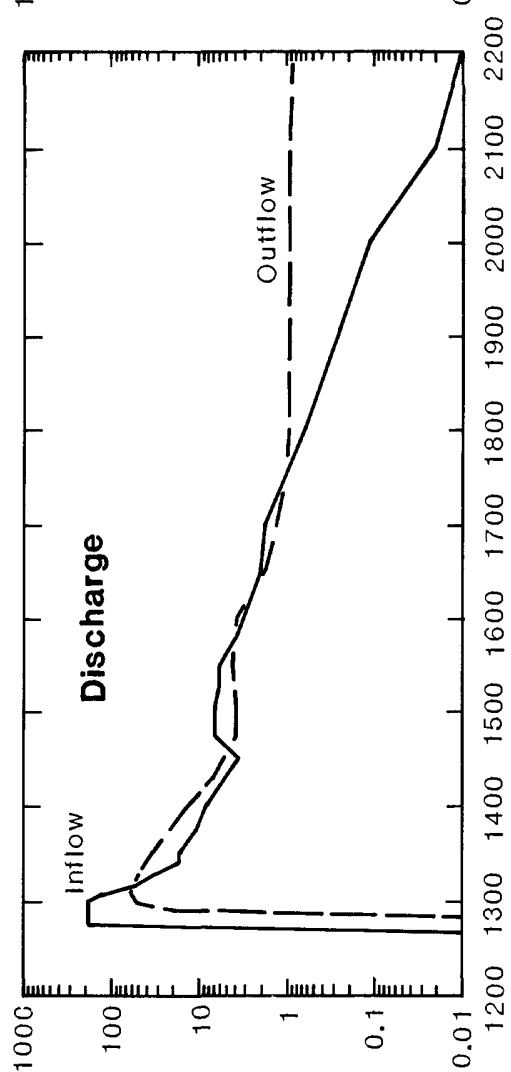

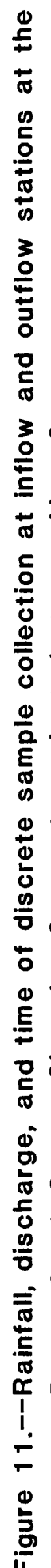

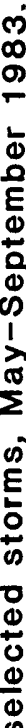



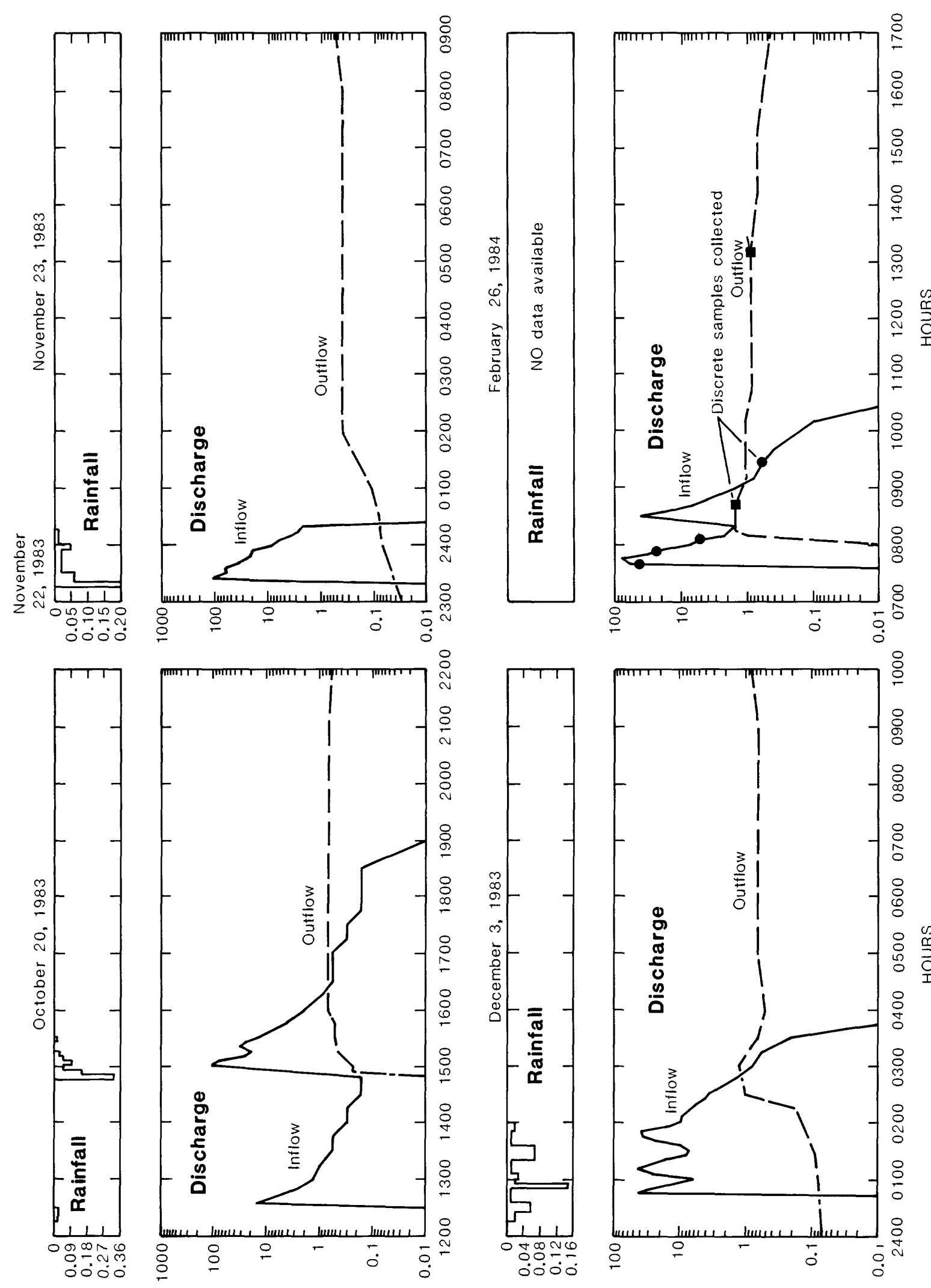

SFHONI NI ONOOJS $y \exists d$ d $1 \exists \exists y$ JIGกO NI 'า7 $\forall$ JNI $\forall$ Y

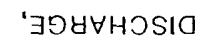

SᄏHONI NI 'าר $\forall$ NI $\forall Y$
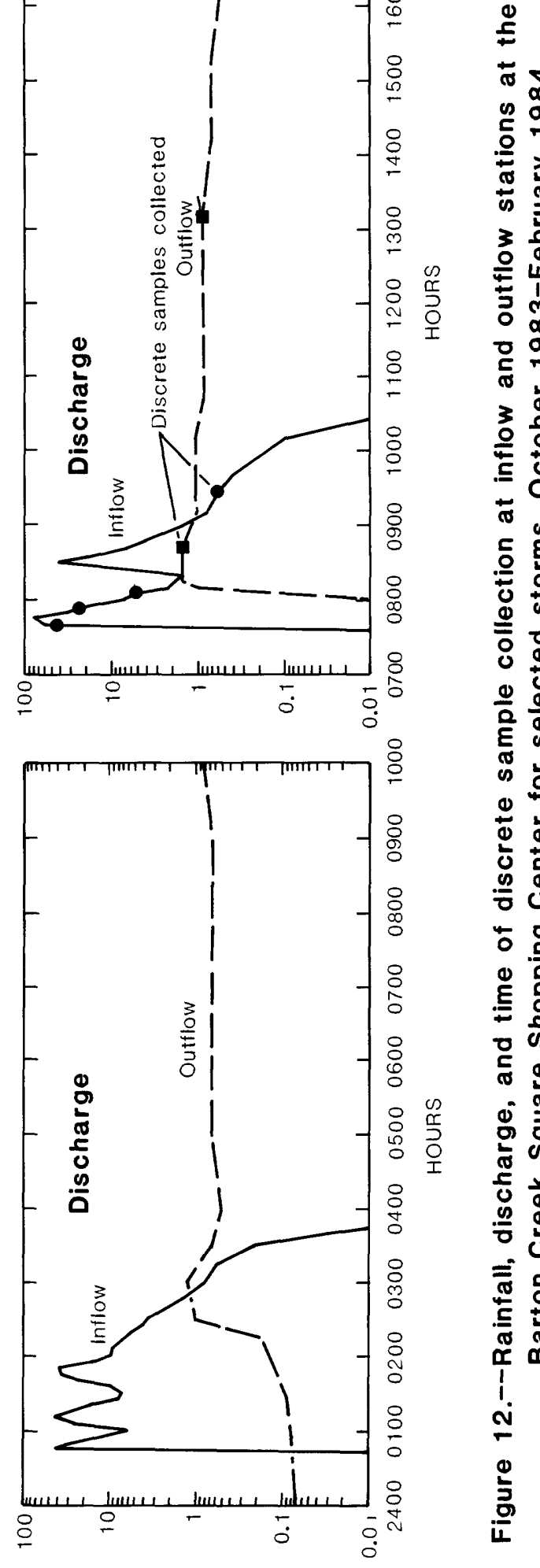

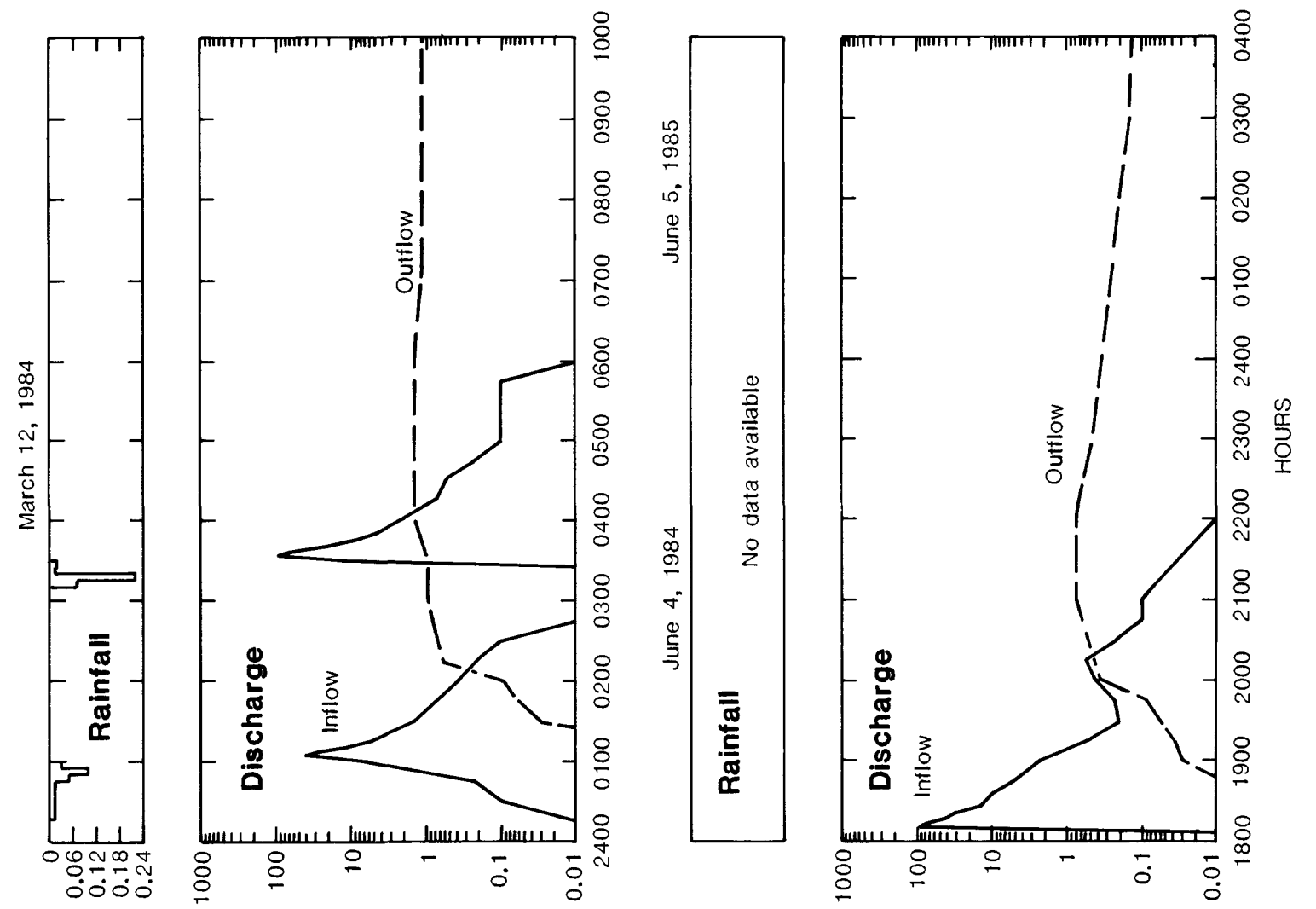

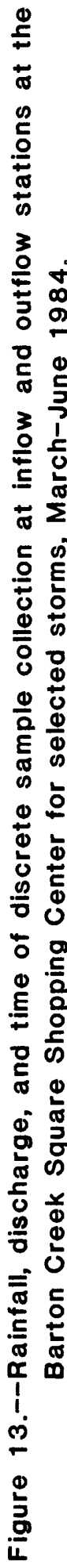
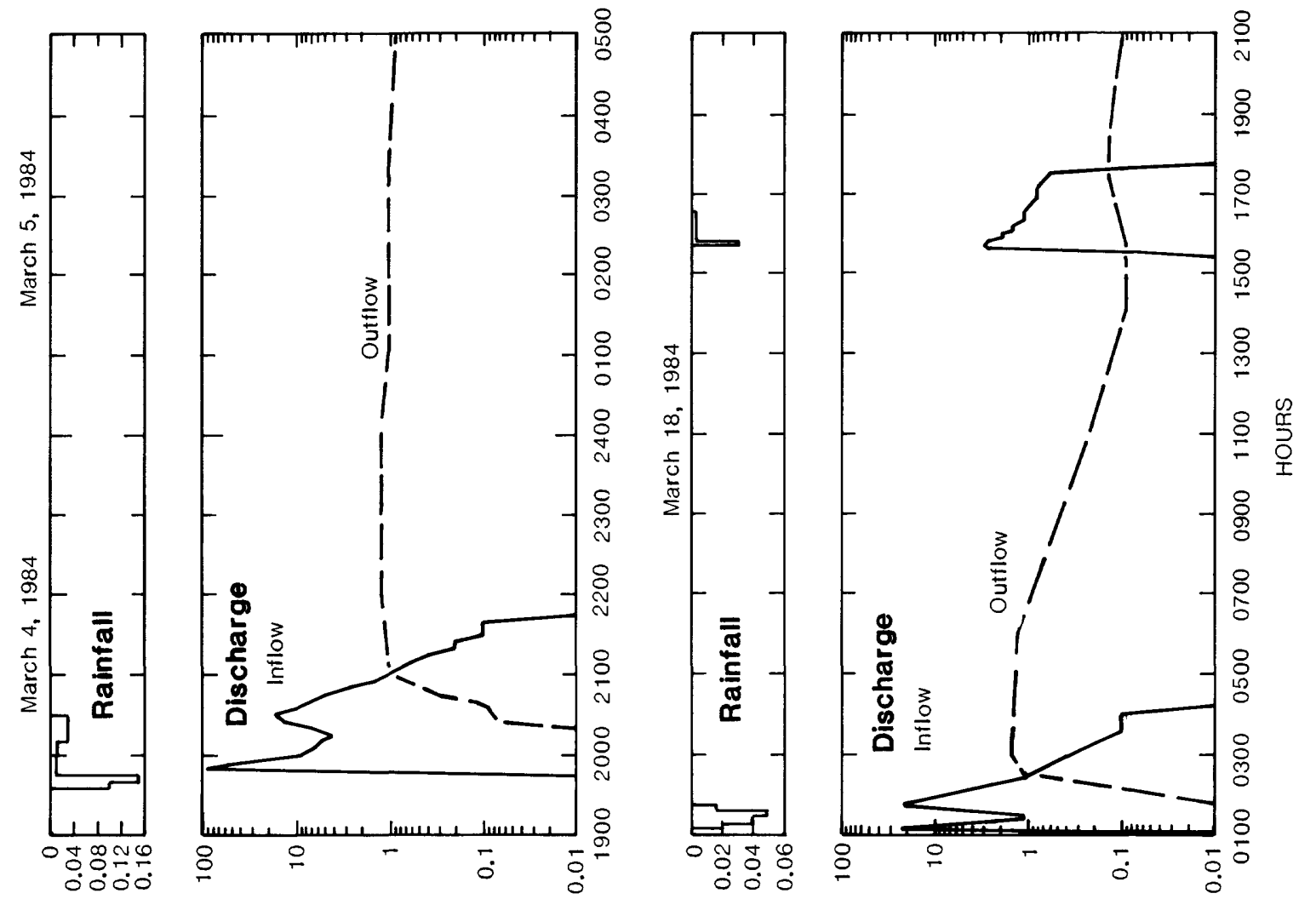

S $\exists H O N I N I \quad$ ONOO $\mathrm{NIS}$ y

S $\exists$ HONI NI

'T7 $A$ NIVY

aNOO $\exists S$ Y

' $\exists$ Y $\forall$ HOSIO 

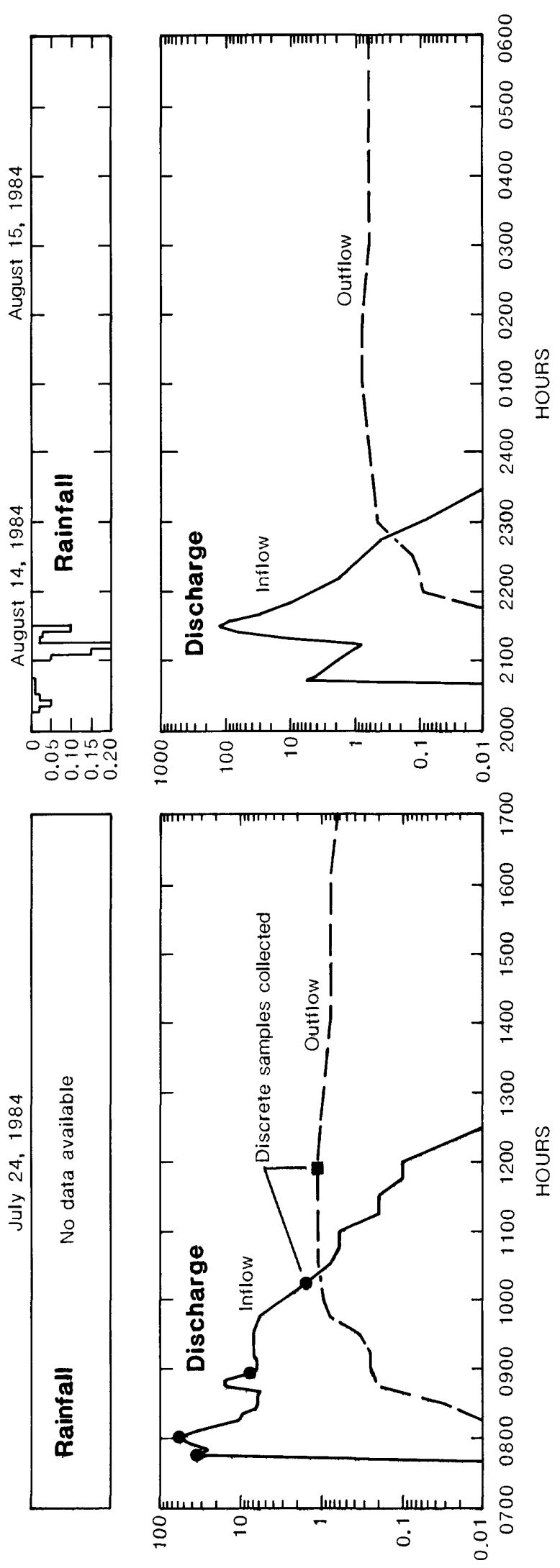

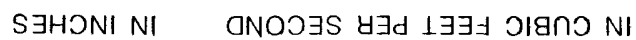

' $7 \forall \exists$ INI $\forall$ Y

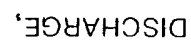


Table 1.--Rainfall-runoff characteristics of selected storms at Barton Creek Square Shoppiny Center

Lin., inch; $\mathrm{ft}^{3} / \mathrm{s}$, cubic foot per second]

\begin{tabular}{|c|c|c|c|c|c|c|c|c|c|c|c|}
\hline \multirow[b]{2}{*}{$\begin{array}{l}\text { Beyin- } \\
\text { niny } \\
\text { date of } \\
\text { storm }\end{array}$} & \multirow[b]{2}{*}{$\begin{array}{l}\text { Duration } \\
\text { (hours) }\end{array}$} & \multicolumn{4}{|c|}{ Rainfall } & \multicolumn{3}{|c|}{ Gayed inflow } & \multicolumn{3}{|c|}{ Gayed outflow } \\
\hline & & $\begin{array}{c}\text { Maximum } \\
5- \\
\text { mi nute } \\
\text { (in.) }\end{array}$ & $\begin{array}{l}\text { Maximum } \\
10- \\
\text { minute } \\
\text { (in.) }\end{array}$ & $\begin{array}{l}\text { Maximum } \\
15- \\
\text { minute } \\
\text { (in.) }\end{array}$ & $\begin{array}{l}\text { Total } \\
\text { depth } \\
\text { (in.) }\end{array}$ & $\begin{array}{r}\text { Runoff } \\
\text { (in.) }\end{array}$ & $\begin{array}{l}\text { Ratio of } \\
\text { runoff to } \\
\text { rainfall }\end{array}$ & $\begin{array}{c}\text { Peak } \\
\text { dis- } \\
\text { charye } \\
\left(\mathrm{ft}^{3} / \mathrm{s}\right)\end{array}$ & $\begin{array}{r}\text { Rurioff } \\
\text { (in.) }\end{array}$ & $\begin{array}{l}\text { Ratio of } \\
\text { runoff to } \\
\text { rainfall }\end{array}$ & $\begin{array}{c}\text { Pedk } \\
\text { dis- } \\
\text { charye } \\
\left(\mathrm{ft}^{3} / \mathrm{s}\right)\end{array}$ \\
\hline $09 / 03 / 82$ & 0.33 & 0.05 & 0.06 & 0.07 & $\mathrm{a} / 10.20$ & U.15 & 0.75 & 21.6 & 0.04 & 0.20 & 1.54 \\
\hline $10 / 07 / 82$ & 1.58 & .15 & .18 & .18 & .35 & $.3 b$ & 1.00 & 33.2 & .18 &.$b 1$ & 2.22 \\
\hline $10 / 28 / 82$ & 0.75 & .40 & .55 & .63 & .90 & $\underline{\mathrm{b} / .53}$ & $.5 y$ & 171.0 & $.2 y$ & .32 & 1.95 \\
\hline $11 / 02 / 82$ & 13.00 & .10 & .17 & .19 & .95 & $\underline{b} / .93$ & .97 & $2 b .9$ & .38 & $.3 y$ & 1.95 \\
\hline $02 / 09 / 83$ & 3.92 & .15 & .17 & .30 & .70 & .60 & .86 & 42.8 & $.2 b$ & .36 & 1.19 \\
\hline $05 / 10 / 83$ & 1.75 & .31 & .51 & .60 & 1.96 & $\mathrm{~b} / 1.90$ & .97 & 94.4 & 1.16 & .59 & 49.10 \\
\hline $06 / 14 / 83$ & 1.75 & .10 & .15 & .20 & .45 & .30 & .67 & 25.0 & .16 & $.3 b$ & 0.93 \\
\hline $08 / 08 / 83$ & 3.58 & .90 & 1.45 & 1.90 & 2.80 & $\mathrm{~b} / 2.08$ & .74 & 185.0 & 1.01 & .36 & 61.30 \\
\hline $09 / 07 / 83$ & 2.25 & 1.30 & 1.75 & 1.95 & 2.88 & $\mathrm{~b} / 1.92$ & .67 & 185.0 & .88 & .30 & $6 b .00$ \\
\hline $10 / 20 / 83$ & 3.25 & .33 & .48 & .53 & .80 & .70 & .88 & 113.0 & .18 & .22 & .68 \\
\hline $11 / 22 / 83$ & 1.00 & .20 & .26 & .32 & .50 & .61 & 1.22 & 113.0 & .16 & .32 & .51 \\
\hline $06 / 04 / 84$ & c/ & c/ & c/ & c/ & .90 & .78 & .87 & 102.0 & $.3 b$ & .39 & .93 \\
\hline $07 / 24 / 84$ & c/ & c/ & c/ & c/ & .94 & .70 & .75 & 59.7 & .22 & .23 & 1.10 \\
\hline $08 / 14 / 84$ & 1.25 & .20 & .35 & .40 & .70 & .71 & 1.01 & 127.0 & .30 & .43 & .75 \\
\hline
\end{tabular}

a) Estimated total rainfall for storm.

b/ Part of yayed inflow estimated.

c/ Total rainfall available only. 
because of the size of the drainage pipes and drop inlets, and because some runoff from large storms overflows the drainage boundaries. It is likely that all storms with a maximum 5-minute rainfall of greater than 0.40 in. will produce a peak discharge of about $185 \mathrm{ft} / \mathrm{s}$ at the inflow gaging station. The average time from the end of the maximum 5-minute rainfall to the gaged inflow peak at the gaging site was 10 minutes for the 22 storms. Five of the 10 minutes is attributed to overland flow, whereas the additional 5 minutes is consumed by pipe flow and flow through the pond inlet. A more concise timing determination cannot be made because of the 5-minute recording interval.

During three of the 22 selected storms, the water stored in the pond overtopped the drop outlet at the pond outflow structure which resulted in the 1 arger outflow peak discharges shown in figure 15. Two of these storms, August 8 and September 7, 1983, were the two high-intensity rainfall storms previously mentioned. The other storm occurred on May 10, 1983, when the pond filter was al ready saturated from two storms that occurred within the 36-hour period prior to this storm. During these storms, flow over the drop outlet structure occurred when inflow minus outflow and losses exceeded the 3.5 acre-ft storage capacity of the pond. The storm of November 2, 1982, also slightly exceeded the 3.5 acre-ft storage capacity, but outflow and losses kept the pond from spilling over the outlet. The time from the beginning of inflow to the beginning of flow over the drop outlet spillway was 40 minutes, 10 minutes, and 90 minutes for the storms of May 10, August 8, and September 7, 1983, respectively. The outflow peak was delayed 5 to 10 minutes after the inflow peak on the occasions when the pond was spilling. For the other 19 storms, when the pond water drained entirely through the filter, no sharp peak was observed, only a much reduced and nearly steady outflow with a very subtle crest that lasted up to several hours. The differences between the inflow-outflow discharge peaks $c$ an be observed in figure 15. For these 19 storms that passed entirely through the filter system, no relation between peak inflow and outflow was evident, al though peak outflows always were less than $3.1 \mathrm{ft}^{3} / \mathrm{s}$.

The outflow characteristics from Pond 1 are affected by the permeability of the sand filter. Silt and clay, washed into the pond are deposited on the pond bed and settle within the sand filter. This accumulation of silt and clay on and within the filter medium reduces the permeability and, thus, the outflow discharge. The condition of the filter--clean or partly clogged--is indicated by peak and average discharge during the period of measurable flow at the outflow station. For example, if the filter is clean, the average and peak discharges would be expected to be larger than when the filter is partly clogged. The distribution of these discharges during the study period is shown in figure 16. The filter systems were partly cleaned prior to the storm of August 8, 1983, and completely cleaned prior to the storm of February 26, 1984. The cleaning in early August may have had a short-term effect, owing to the 1 arge storms in August and September 1983, which probably deposited 1 arge quantities of $\mathrm{cl}$ ay and silt particles in the pond. Figure 16 shows that peak outflows increased slightly after the February 1984 cleaning. The peak flows were 1 argest during the early part of the study period when the filter system was new, which indicates that the cleaning may have improved the flow-through capacity of the filter, but did not restore it completely. 


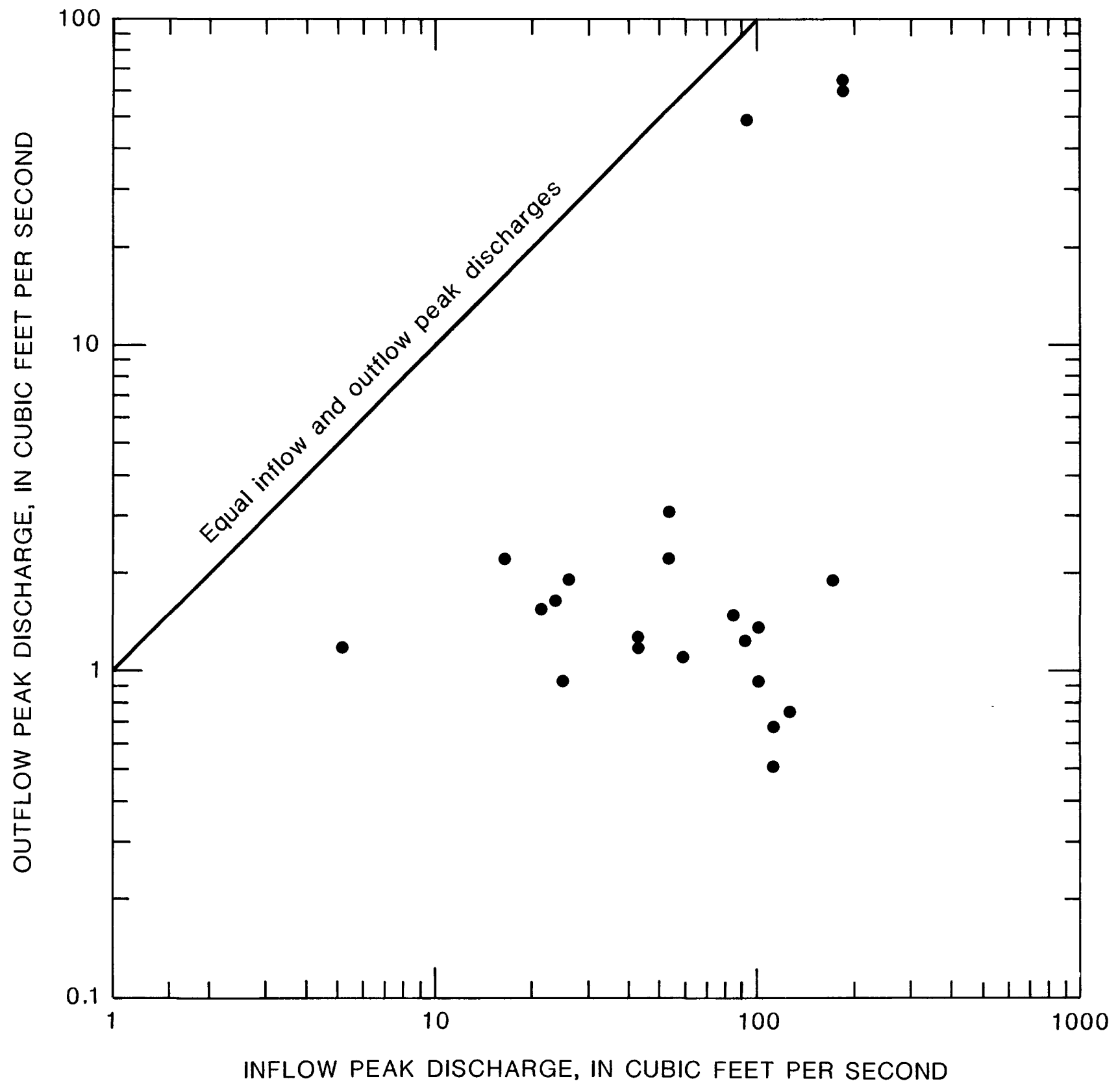

Figure 15.--Relationship of peak discharges for selected storms between inflow and outflow stations at Barton Creek Square Shopping Center. 


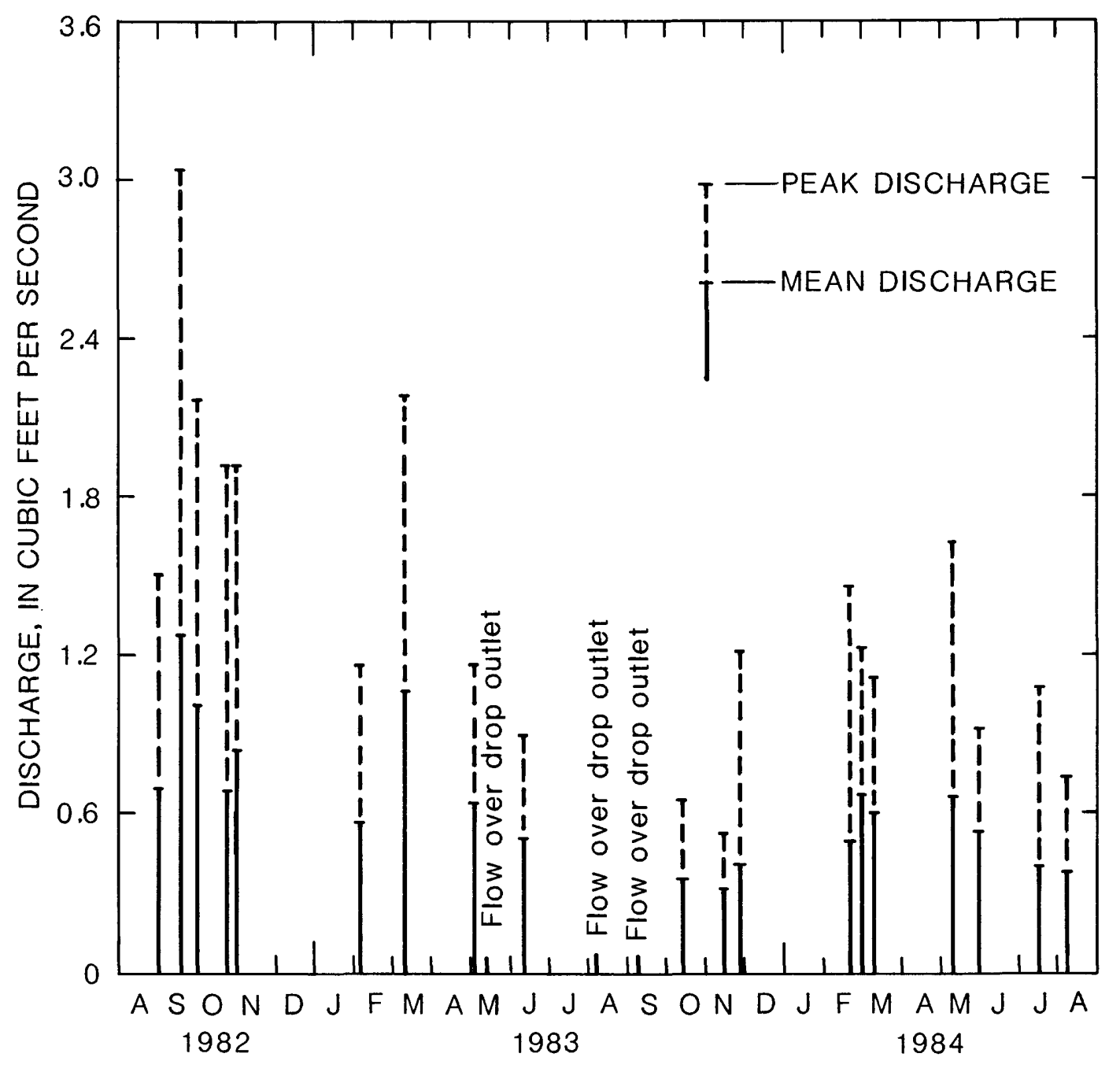

Figure 16.--Peak and mean discharge during storm runoff from outflow station at Barton Creek Square Shopping Center. 
Total runoff is directly rel ated to total rainfall and is commonly expressed as a ratio of runoff to rainfall. In addition, runoff al so is rel ated to rainfall intensities, rainfall duration, and antecedent soil moisture. In a typical watershed, the runoff-rainfall ratio will increase for storms with 1 arger rainfall intensities and 1 arger total rainfall. The runoff-rainfall data are plotted in figure 17.

At the inflow station, the runoff-rainfall ratio ranged from 0.56 to 1.22 and averaged 0.83 . The variation of the runoff-rainfall ratio (fig. 17) is approximately evenly distributed about the mean ratio line, except for small and large rainfall storms, when ratios are below the mean. The storms with ratios of 1.00 or greater probably were caused by storms with a large variation in the areal distribution of the rain or by inaccuracies in the data. The relatively small ratios associated with the 1 arge storms were caused by runoff overflowing a drainage divide and bypassing the gaging station and possibly by errors in the gaging of the streamflow.

At the outflow station, the runoff-rainfall ratio ranged from 0.20 to 0.59 and averaged 0.36 . The distribution of the ratios appear to be evenly distributed about the mean ratio 1 ine. As expected, the ratios for very small storms were below the average because much of the inflow was needed to saturate the pond filter.

\section{Water Budget}

The movement of water through Pond 1 , was examined by preparing a water budget for each storm. The budget components consisted of measured inflow and outflow, estimated ungaged inflow, rainfall on the pond, evaporation from the pond, and the amount of water necessary to saturate the filter and the pond bank. The equation identifying the components of the water budget is shown below:

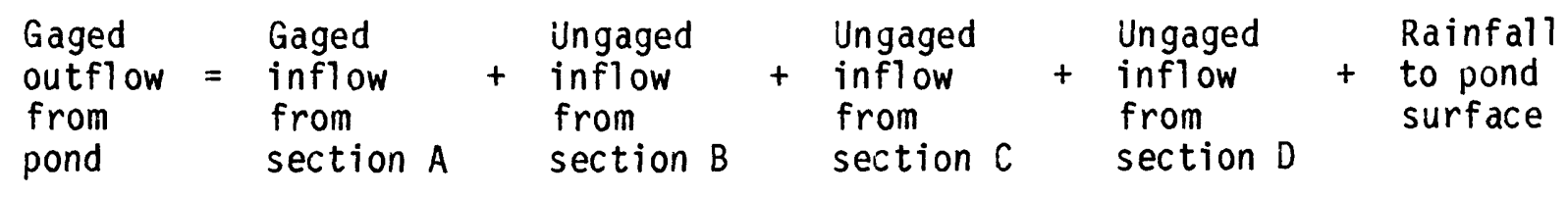

$\begin{array}{ll}\text { Evaporation } & \begin{array}{l}\text { Pond bank and } \\ \text { - loss }\end{array} \\ & \text { filter } \\ & \text { Saturation } \\ \text { loss } & \text { losses }\end{array}$

The ungaged inflow was estimated for each of the three sections $B$, $C$, and $D$, using the U.S. Soil Conservation Service method with "at site" estimates of antecedent soil moisture (U.S. Department of Agriculture, 1972). Rainfall on the pond was determined from daily rainfall data collected at the pond. Evaporation from the pond was estimated using average daily evaporation for each month for the period of time that the pond contained water. The amount of water required to saturate the filter to field capacity (the moisture capacity of the filter material required before any drainage occurs) was estimated on a daily basis before each storm. On days when rainfall occurred, inflow was 


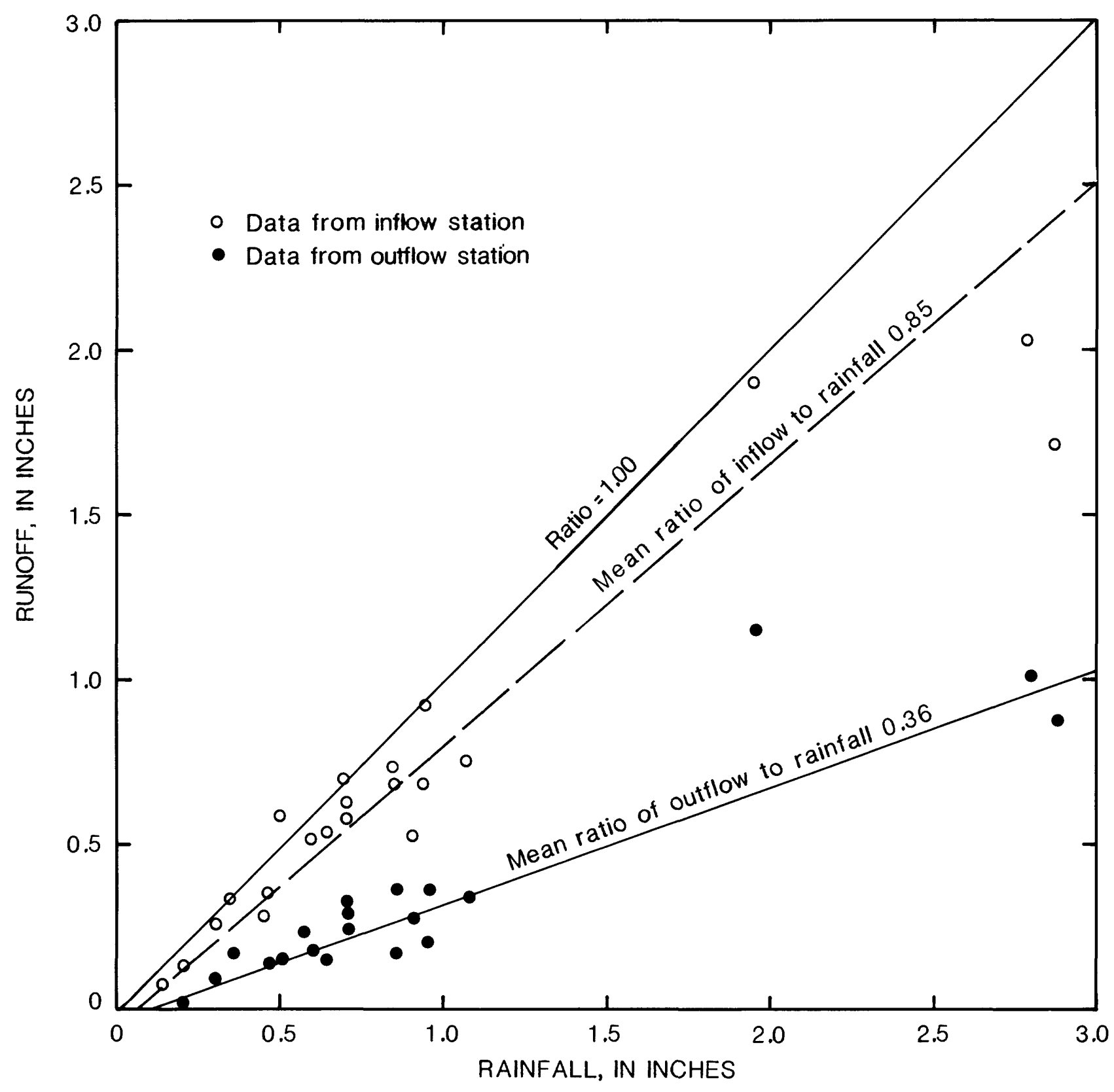

Figure 17.--Relation between storm rainfall and runoff volumes in the inflow and outflow stations at Barton Creek Square Shopping Center. 
determined and the portion of this water stored in excess of the field capacity of the filter material was removed via outflow drainage. On days with no rainfall when the pond was no longer draining, the remaining water stored in the filter was reduced on a daily basis by evaporation, resulting in a pre-storm filter moisture deficit. Table 2 details gaged inflow, estimates of inflow from ungaged areas that includes rainfall on the pond surface, and losses for the 22 storms. The differences between gaged inflow, estimated ungaged inflow, pond evaporation loss, pond filter and bank storage saturation losses, and gaged outflow are called unexplained losses. The unexplained losses are a combination of errors in measured inflow and outflow, estimated inflow, and estimated evaporation and saturation losses as well as the possibility of seepage through the base of the pond and the occurrence of some minor outflow from the pond after the gaging had ended. These losses ranged from nearly 0 to 49 percent of the total inflow and averaged 20 percent.

\title{
Quality of Water
}

\section{Discharge-Weighted Concentrations}

\begin{abstract}
Water-quality samples collected at the inflow station are representative of water from Barton Creek Square Shopping Center and the parking lots surrounding the mall (fig. 2, section A). These data are presented in table 3 . If little or no runoff occurred from sections $B, C$, or $D$, these data were used to represent the total runoff into pond 1. For the storms in which significant quantities of runoff occurred from the ungaged areas, the runoff and concentrations or densities of constituents were estimated and used in conjunction with data from the gaged area to determine the total inflow and discharge-weighted concentrations to Pond 1 . The estimated concentrations or densities of constituents from the ungaged area were based on manually collected samples from sections $B$ and $D$. These data are presented in tables 4 and 5 . Water-quality data collected at the outflow from Pond 1 are presented in table 6 .
\end{abstract}

The discussions that follow represent total inflow into Pond 1 ; consequently, for those storms where runoff from the ungaged area was estimated, inflow data presented in the following discussions will differ from the data in table 3. Because the ungaged inflow generally was less than 10 percent of the gaged inflow for most storms, estimated discharge-weighted concentrations for the total inflow did not vary substantially from the measured inflow except for suspended solids. In some instances, the estimated discharge-weighted concentrations of suspended solids were substancially higher than concentrations for the gaged inflow, primarily because of contributions from runoff from unvegetated areas adjacent to Pond 1.

Fecal-col iform and fecal-streptococci bacteria

In general, discharge-weighted densities of fecal-coliform and fecalstreptococci bacteria were substantially larger in the inflow than in the outflow (fig. 18). Discharge-weighted densities of fecal coliform in the outflow exceeded those in the inflow on only one occasion and for streptococci on two occasions. Densities in the outflow at these times were only slightly larger, and variations may be due to sampling or analytical error. Discharge-weighted fecal-coliform densities in the inflow ranged from 200 to over 1 million cols.l 

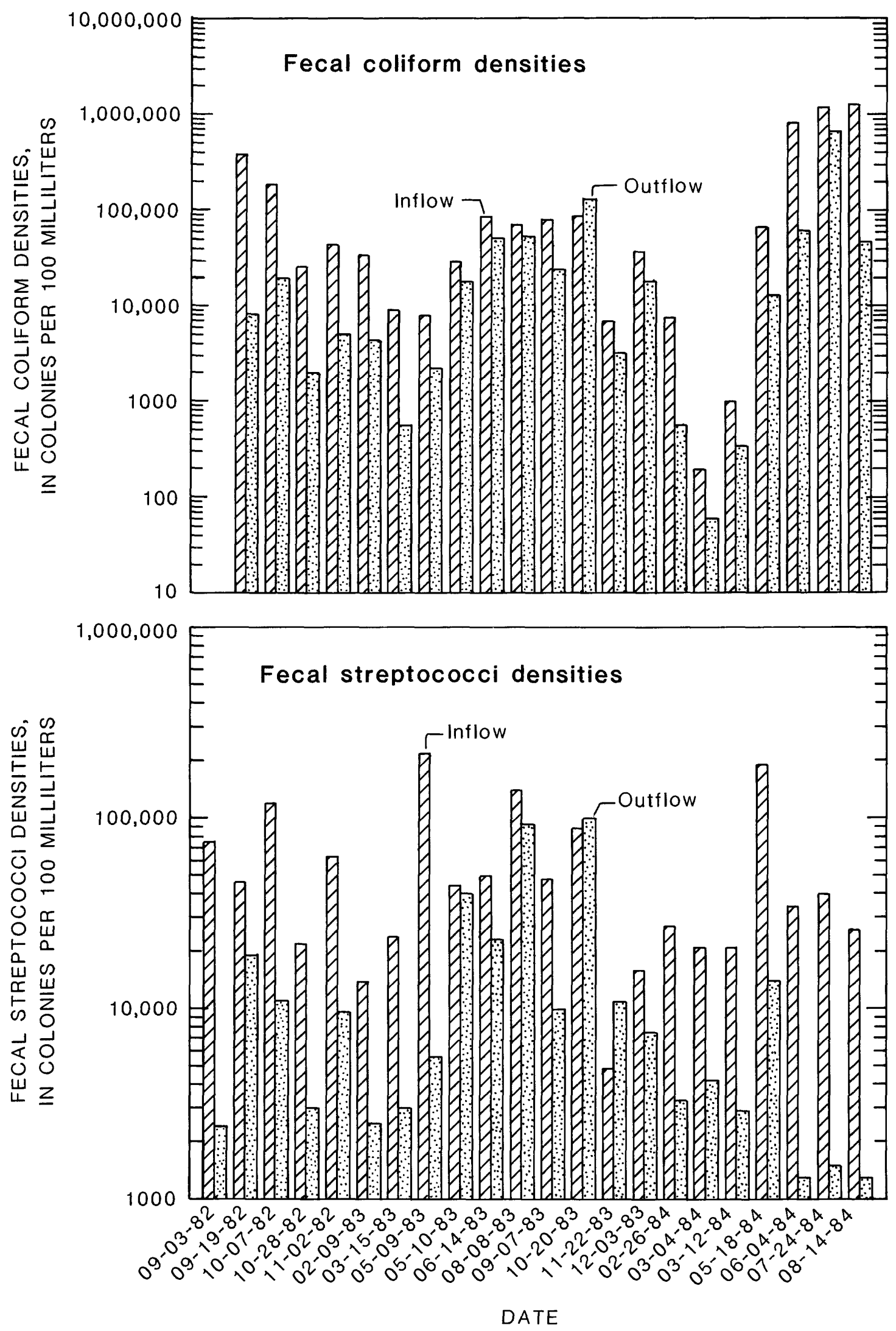

Figure 18.--Densities of fecal-coliform and fecal-streptococci bacteria in the inflow and outflow of Pond 1 at Barton Creek Square Shopping Center. 

Table 2.--Water budget of selected storms at Barton Creek Square Shopping Center

\begin{tabular}{|c|c|c|c|c|c|c|}
\hline $\begin{array}{l}\text { Beginning } \\
\text { date of } \\
\text { storm } \\
\end{array}$ & Gaged & $\begin{array}{l}\text { Inflow } \\
\text { Ungaged }\end{array}$ & Total & $\begin{array}{l}\text { Outflow, } \\
\text { gaged }\end{array}$ & $\begin{array}{l}\text { Evaporation } \\
+ \text { saturation }\end{array}$ & $\begin{array}{l}\text { Unexplained } \\
\text { losses }\end{array}$ \\
\hline 09/03/82 & 0.59 & 0.01 & 0.60 & 0.27 & 0.28 & 0.05 \\
\hline $09 / 19 / 82$ & 2.85 & .05 & 2.90 & 2.58 & .28 & .04 \\
\hline $10 / 07 / 82$ & 1.37 & .02 & 1.39 & 1.25 & .01 & .13 \\
\hline $10 / 28 / 82$ & $\underline{a} / 2.08$ & .20 & 2.28 & 1.94 & .28 & .06 \\
\hline $11 / 02 / 82$ & $\underline{a} / 3.61$ & .24 & 3.85 & 2.54 & .15 & 1.16 \\
\hline $02 / 09 / 83$ & 2.34 & .22 & 2.56 & 1.67 & .04 & .85 \\
\hline $03 / 15 / 83$ & 2.12 & .04 & 2.16 & 1.28 & .13 & .75 \\
\hline $05 / 09 / 83$ & .31 & .01 & .32 & .22 & .08 & .02 \\
\hline $05 / 10 / 83$ & $\underline{a} / 7.41$ & 1.01 & 8.42 & 7.85 & .03 & .54 \\
\hline $06 / 14 / 83$ & 1.18 & .03 & 1.21 & 1.07 & .13 & .01 \\
\hline $08 / 08 / 83$ & $\underline{\mathrm{a}} / 8.08$ & 1.48 & 9.56 & 6.82 & .03 & 2.71 \\
\hline $09 / 07 / 83$ & a/ $/ 7.47$ & 1.60 & 9.07 & 5.98 & .39 & 2.70 \\
\hline $10 / 20 / 83$ & 2.72 & .06 & 2.78 & 1.21 & .30 & 1.27 \\
\hline $11 / 22 / 83$ & 2.36 & .03 & 2.39 & 1.06 & .32 & 1.01 \\
\hline $12 / 03 / 83$ & 2.49 & .22 & 2.71 & 2.23 & .01 & .47 \\
\hline $02 / 26 / 84$ & 2.16 & .06 & 2.22 & 1.05 & .09 & 1.08 \\
\hline $03 / 04 / 84$ & 1.44 & .06 & 1.50 & 1.03 & .11 & .36 \\
\hline $03 / 12 / 84$ & 1.75 & .12 & 1.87 & 1.73 & .08 & .06 \\
\hline $05 / 18 / 84$ & 1.05 & .02 & 1.07 & .69 & .18 & .20 \\
\hline $06 / 04 / 84$ & 3.02 & .13 & 3.15 & 2.39 & .26 & .50 \\
\hline $07 / 24 / 84$ & 2.74 & .05 & 2.79 & 1.48 & .54 & .77 \\
\hline $08 / 14 / 84$ & 2.78 & .04 & 2.82 & 2.01 & .36 & .45 \\
\hline
\end{tabular}

a/ Part of gaged inflow estimated. 
Table 3.- - Water analyses of the inflow to Barton Creek Square Shopping Center

$[\mathrm{ft} 3 / \mathrm{s}$, cubic foot per second; $\mu \mathrm{S} / \mathrm{cm}$, microsiemens per centimeter at 25 degrees Celsius; mg/L, milligram per liter; cols. $/ 100 \mathrm{~mL}$, colonies per $100 \mathrm{milliliters;} \mathrm{K}$, non-ideal colony count; $\mu \mathrm{g} / \mathrm{L}$, microgram per liter]

03155330 Skunk Hollow Creek above Pond 1 at Austin, Texas

\begin{tabular}{|c|c|c|c|c|c|c|c|c|c|c|c|}
\hline & Date & Time & $\begin{array}{c}\text { hean } \\
\text { sample } \\
\text { dis- } \\
\text { charge } \\
\text { (ft } 3 / \mathrm{s})\end{array}$ & $\begin{array}{c}\text { Instan- } \\
\text { taneous } \\
\text { sample } \\
\text { dis- } \\
\text { charge } \\
\left(\mathrm{ft}^{3} / \mathrm{s}\right)\end{array}$ & $\begin{array}{l}\text { Spe- } \\
\text { cific } \\
\text { con- } \\
\text { duct- } \\
\text { ance } \\
(\mathrm{HS} / \mathrm{cm})\end{array}$ & $\begin{array}{l}\text { Oxygen } \\
\text { demand, } \\
\text { chem- } \\
\text { ical } \\
\text { ( high } \\
\text { level) } \\
\text { (mg/L) }\end{array}$ & $\begin{array}{l}\text { Oxygen } \\
\text { demand, } \\
\text { bio- } \\
\text { chem- } \\
\text { ical, } \\
5 \text { day } \\
(\mathrm{mg} / \mathrm{L})\end{array}$ & $\begin{array}{l}\text { Coli- } \\
\text { form, } \\
\text { fecal, } \\
0.7 \\
\text { UM-MF } \\
\text { (cols./ } \\
100 \mathrm{~mL} \text { ) }\end{array}$ & $\begin{array}{l}\text { Strep- } \\
\text { tococci } \\
\text { fecal, } \\
\mathrm{KF} \mathrm{Agar} \\
\text { (cols./ } \\
100 \mathrm{~mL})\end{array}$ & $\begin{array}{l}\text { Solids, } \\
\text { residue } \\
\text { dt } \\
180^{\circ} \mathrm{C}, \\
\text { dis- } \\
\text { solved } \\
(\mathrm{mg} / \mathrm{L})\end{array}$ & $\begin{array}{l}\text { Solids, } \\
\text { residue } \\
\text { at } \\
105^{\circ} \mathrm{C}, \\
\text { sus- } \\
\text { pended } \\
\text { (mg/L) }\end{array}$ \\
\hline \multicolumn{12}{|c|}{ Sept. 1982} \\
\hline & $03-03$ & $2120-2400$ & 2.6 & -- & 407 & 760 & 82 & -- & 75,000 & 411 & 816 \\
\hline & $03 \ldots$ & 2130 & -- & 16 & 491 & 900 & $>44$ & -- & 120,000 & 518 & 1530 \\
\hline & $03 \ldots$ & 2137 & -- & 11 & 428 & 700 & $>46$ & -- & 100,000 & 434 & 876 \\
\hline & $03 \ldots$ & 2153 & -- & 3.4 & 313 & 420 & 56 & -- & 190,000 & 324 & 442 \\
\hline & $03 \ldots$ & 2223 & -- & 1.5 & 257 & 270 & 37 & -- & 62,000 & 262 & 94 \\
\hline & $03 \ldots$ & 2300 & -- & 0.42 & 251 & 240 & 35 & -- & 8,800 & 264 & 69 \\
\hline & $19-20$ & $2305-0520$ & 4.8 & -- & 35 & 49 & 8.2 & 400,000 & 46,000 & 69 & 103 \\
\hline & $19 \ldots$ & 2313 & $\rightarrow$ & 4.1 & 369 & 420 & $82 \quad 2$ & $2,200,000$ & 470,000 & 394 & 288 \\
\hline & $19 .$. & 2328 & -- & 29 & $14 J$ & 180 & 252 & $2,000,000$ & 160,000 & 126 & 274 \\
\hline & $19 \ldots$ & 2358 & -- & 20 & 57 & 26 & 5.8 & 30,000 & 38,000 & 56 & 163 \\
\hline & $20 \ldots$ & 0028 & -- & & 75 & 30 & 4.0 & 25,000 & 34,000 & 66 & 35 \\
\hline & $20 \ldots$ & 0052 & -- & 3.6 & 32 & -- & -- & 6,300 & 44,000 & -- & -- \\
\hline \multicolumn{12}{|c|}{ Oct. } \\
\hline & $07-07$ & $1550-1950$ & 3.8 & -- & 81 & 86 & 9.9 & 190,000 & 120,000 & 74 & 160 \\
\hline & $28-23$ & $2140-2400$ & 11 & -- & 56 & 57 & 9.0 & 9,200 & 21,000 & 39 & 430 \\
\hline \multicolumn{12}{|c|}{ Nov. } \\
\hline & $02-02$ & $1345-2400$ & 4.0 & $\ddot{-}$ & 93 & 73 & 12 & 46,000 & 64,000 & 93 & 62 \\
\hline & $02 \ldots$ & 1350 & -- & 26 & 115 & 160 & 24 & $K 4,800$ & 90,000 & 128 & 273 \\
\hline & $02 \ldots$ & 1435 & -- & 2.8 & 88 & 74 & 11 & 25,000 & 30,000 & 86 & 30 \\
\hline & $0 ? \ldots$ & 1515 & -- & 0.96 & 97 & 82 & 9.6 & 9,200 & 71,000 & 38 & 30 \\
\hline & $02 \ldots$ & 1800 & - & 2.4 & 83 & 40 & 5.1 & $k 8,000$ & 52,000 & 70 & 26 \\
\hline \multirow[t]{2}{*}{ Feb. } & 1983 & & & & & & & & & & \\
\hline & $09-09$ & $0900-2000$ & 2.6 & -- & 53 & 36 & 4.2 & $\mathrm{~K} 36,000$ & 14,000 & 50 & 126 \\
\hline \multicolumn{12}{|c|}{ Mar. } \\
\hline & $15-15$ & $1740-2400$ & 4.0 & -- & 57 & 53 & 9.3 & 9,200 & 24,000 & 61 & 58 \\
\hline \multicolumn{12}{|l|}{ May } \\
\hline & $09-09$ & $1300-1530$ & 1.4 & -- & 206 & 310 & 39 & K9,000 & 220,000 & 228 & 496 \\
\hline \multirow{2}{*}{\multicolumn{12}{|c|}{ June }} \\
\hline & & & & & & & & & & & \\
\hline & $14-14$ & $1640-2400$ & 1.9 & $=$ & 155 & 140 & 25 & 84,000 & 50,000 & 158 & 434 \\
\hline & $14 \ldots$ & 1643 & -- & 21 & 383 & 380 & 40 & 120,000 & 160, & 349 & 2170 \\
\hline & $14 \ldots$ & 1655 & -- & 3.7 & 129 & 130 & 22 & 29,000 & 56,000 & 150 & 308 \\
\hline & $14 \ldots$ & 1720 & -- & 7.3 & 93 & 76 & 13 & 21,000 & 22, & 113 & 312 \\
\hline & $14 \ldots$ & 1750 & -- & 7.3 & 96 & 67 & 9.3 & 22,000 & 14,000 & 101 & 148 \\
\hline \multicolumn{12}{|c|}{ Aug. } \\
\hline & $08-08$ & $1240-2200$ & 10 & -- & 57 & 64 & 3.3 & 78,000 & $\mathrm{~K} 160,000$ & 55 & 655 \\
\hline \multicolumn{12}{|c|}{ Sept. } \\
\hline & $07-10$ & $1420-2400$ & 0.99 & -- & 118 & 100 & 14 & 90,000 & 46,000 & 102 & 171 \\
\hline \multicolumn{12}{|c|}{ Oct. } \\
\hline & $20-20$ & $1230-1900$ & 5.0 & -- & 75 & 58 & 5.1 & 90,000 & 89,000 & 68 & 90 \\
\hline \multicolumn{12}{|c|}{ Nov. } \\
\hline & $22-23$ & $2320-0025$ & 26 & -- & 89 & 130 & 15 & K7,000 & 49,000 & 81 & 193 \\
\hline \multicolumn{12}{|c|}{ Dec. } \\
\hline \multirow{6}{*}{ Feb. } & & & & & & & & & & & \\
\hline & $\begin{array}{l}1984 \\
26-26\end{array}$ & $0735-1025$ & 9.2 & -- & 120 & 110 & 11 & $K 7,500$ & 27,000 & 106 & 100 \\
\hline & $26 \ldots$ & 0737 & $\ldots$ & 43 & 330 & 240 & 24 & 8,000 & $\mathrm{~K} 13,000$ & 264 & 283 \\
\hline & $26 \ldots$ & 0754 & -- & 24 & 46 & 58 & 6.2 & $\mathrm{k} 11,000$ & $\mathrm{~K} 16,000$ & 34 & 147 \\
\hline & $26 \ldots$ & 0805 & -- & 5.0 & 46 & 29 & 3.5 & 3,800 & $K 19,000$ & 30 & 62 \\
\hline & $26 \ldots$ & 0917 & -- & 0.6 & 77 & 23 & 3.0 & 1,400 & 29,000 & 52 & 14 \\
\hline \multirow[t]{5}{*}{ Mar. } & & & & & & & & & & & \\
\hline & $04-04$ & $1945-2145$ & 8.7 & -- & 82 & 83 & 8.9 & 200 & 21,000 & 72 & 160 \\
\hline & $12-12$ & $0015-0600$ & 3.7 & -- & 92 & 47 & 4.0 & 480 & 21,000 & 75 & 39 \\
\hline & $23 \ldots$ & 0944 & -- & -- & 84 & 24 & 4.4 & -- & -- & 59 & 31 \\
\hline & & & & & & $-33-$ & & & & & \\
\hline
\end{tabular}


Table 3.- - Water analyses of the inflow to Barton Creek Square Shopping Center--Continued

\begin{tabular}{|c|c|c|c|c|c|c|c|c|c|c|}
\hline Date & Time & $\begin{array}{l}\text { Mean } \\
\text { sample } \\
\text { dis } \\
\text { charge } \\
\left(\mathrm{ft}^{3} /\right.\end{array}$ & $\begin{array}{l}\text { Tnstä } \\
\text { taneo } \\
\text { samp } \\
\text { dis } \\
\text { char } \\
\left(\mathrm{ft}^{3} /\right.\end{array}$ & $\begin{array}{ll}\text { Spe- } \\
\text { us } & \text { cific } \\
\text { of } & \text { con- } \\
- & \text { duct- } \\
\text { ge } & \text { ance } \\
\text { s) } & (\mu \mathrm{S} / \mathrm{cm}\end{array}$ & $\begin{array}{l}\text { Jxyger } \\
\text { demand } \\
\text { chem- } \\
\text { ical } \\
\text { (high } \\
\text { level } \\
\text { (mg/L) }\end{array}$ & $\begin{array}{l}\text { Jxygen } \\
\text { deinand, } \\
\text { bio- } \\
\text { chem- } \\
\text { ical, } \\
5 \text { day } \\
\text { (mg/L) }\end{array}$ & $\begin{array}{l}\text { Coli- } \\
\text { forin, } \\
\text { fecal, } \\
0.7 \\
\text { UM-MF } \\
\text { (cols./ } \\
100 \mathrm{~mL} \text { ) }\end{array}$ & $\begin{array}{l}\text { Strep- } \\
\text { tococci } \\
\text { fecal, } \\
\mathrm{KF} \text { Ayar } \\
\text { (col s./ } \\
100 \mathrm{~mL} \text { ) }\end{array}$ & $\begin{array}{l}\text { Solids, } \\
\text { residue } \\
\text { at } \\
180^{\circ} \mathrm{C}, \\
\text { dis- } \\
\text { solved } \\
(\mathrm{mg} / \mathrm{L})\end{array}$ & $\begin{array}{l}\text { Solids, } \\
\text { residue } \\
\text { at } \\
105^{\circ} \mathrm{C}, \\
\text { sus- } \\
\text { pended } \\
\text { (mg/L) }\end{array}$ \\
\hline $\begin{array}{c}\text { May } 1984 \\
18-18\end{array}$ & $0105-1815$ & 0.7 & -- & 87 & 130 & - & 68,000 & 190,000 & 80 & 243 \\
\hline June $04-05$ & $1805-0800$ & 2.6 & -- & 124 & 210 & 17 & 340,000 & 35,000 & 106 & 24 \\
\hline $\begin{array}{l}\text { July } \\
\\
24-24 \\
24 \ldots \\
24 \ldots \\
24 \ldots \\
24 \ldots\end{array}$ & $\begin{array}{l}0740-1230 \\
0745 \\
0800 \\
0835 \\
1015\end{array}$ & $\begin{array}{l}6.8 \\
-- \\
-- \\
--\end{array}$ & $\begin{array}{c}-- \\
36 \\
60 \\
5.2 \\
1 .\end{array}$ & $\begin{array}{l}-- \\
-- \\
-- \\
--\end{array}$ & $\begin{array}{r}43 \\
32 \\
100 \\
310 \\
90\end{array}$ & $\begin{array}{c}21 \\
-2 \\
10 \\
8.3 \\
6.7\end{array}$ & $\begin{array}{r}\mathrm{K} 1200,000 \\
3900,000 \\
140,000 \\
200,000 \\
\mathrm{~K} 150,000\end{array}$ & $\begin{array}{r}40,000 \\
380,000 \\
5,000 \\
21,000 \\
15,000\end{array}$ & $\begin{array}{r}86 \\
471 \\
50 \\
53 \\
60\end{array}$ & $\begin{array}{l}108 \\
495 \\
103 \\
16 \\
14\end{array}$ \\
\hline Aug. $14-14$ & $2040-2330$ & 11 & -- & 72 & 40 & 5.9 & $\mathrm{~K} 1300,000$ & 26,000 & 56 & 11 \\
\hline Date & $\begin{array}{l}\text { Solids, } \\
\text { vola- } \\
\text { tile, } \\
\text { dis- } \\
\text { solved } \\
(\mathrm{mg} / \mathrm{L})\end{array}$ & $\begin{array}{l}\text { Nitro- } \\
\text { gen, } \\
\text { total } \\
(\mathrm{mg} / \mathrm{L} \\
\text { as } N)\end{array}$ & $\begin{array}{c}\text { Nitro- } \\
\text { Jen, } \\
\text { No2+NO3, } \\
\text { total } \\
\text { (mg } / \mathrm{L} \\
\text { as } \mathrm{N} \text { ) }\end{array}$ & $\begin{array}{l}\text { Nitro- } \\
\text { gen, am- } \\
\text { monia + } \\
\text { organic, } \\
\text { total } \\
(\mathrm{mg} / \mathrm{L} \\
\text { as } \mathrm{N}) \\
\end{array}$ & $\begin{array}{l}\text { Phos- } \\
\text { phorus, } \\
\text { total } \\
\text { (mg/L } \\
\text { as P) }\end{array}$ & $\begin{array}{l}\text { Carbon, } \\
\text { organic, } \\
\text { total } \\
(\mathrm{mg} / \mathrm{L} \\
\text { as C) }\end{array}$ & $\begin{array}{l}\text { Cadmium, } \\
\text { dis- } \\
\text { solved } \\
(\mu g / L)\end{array}$ & $\begin{array}{l}\text { Iron, } \\
\text { dis- } \\
\text { solved } \\
(\mu y / L)\end{array}$ & $\begin{array}{l}\text { Lead, } \\
\text { dis- } \\
\text { solved } \\
(\mu \mathrm{g} / \mathrm{L})\end{array}$ & $\begin{array}{l}\text { Zinc, } \\
\text { dis- } \\
\text { solved } \\
(\mu g / L)\end{array}$ \\
\hline $\begin{array}{r}\text { Sept. } 1982 \\
03-03 \\
03 \ldots \\
03 \ldots \\
03 \ldots \\
03 \ldots \\
03 \ldots\end{array}$ & $\begin{array}{l}186 \\
228 \\
189 \\
146 \\
122 \\
126\end{array}$ & $\begin{array}{c}8.3 \\
16 \\
3.4 \\
3.0 \\
2.5 \\
4.3\end{array}$ & $\begin{array}{l}0.55 \\
0.30 \\
0.60 \\
0.80 \\
1.10 \\
1.00\end{array}$ & $\begin{array}{c}7.8 \\
16 \\
2.8 \\
2.2 \\
1.4 \\
3.3\end{array}$ & $\begin{array}{l}0.43 \\
0.34 \\
0.42 \\
0.98 \\
0.27 \\
0.15\end{array}$ & $\begin{array}{c}160 \\
200 \\
180 \\
130 \\
85 \\
74\end{array}$ & $\begin{array}{r}<1 \\
<1 \\
<1 \\
<1 \\
<1 \\
1\end{array}$ & $\begin{array}{l}350 \\
380 \\
290 \\
300 \\
200 \\
160\end{array}$ & $\begin{array}{l}3 \\
3 \\
4 \\
2 \\
5 \\
3\end{array}$ & $\begin{array}{r}70 \\
50 \\
40 \\
50 \\
200 \\
220\end{array}$ \\
\hline $\begin{array}{l}19-20 \\
19 \ldots \\
19 \ldots \\
19 \ldots \\
20 \ldots \\
20 \ldots\end{array}$ & $\begin{array}{r}30 \\
200 \\
56 \\
27 \\
28 \\
--\end{array}$ & $\begin{array}{c}1.3 \\
10 \\
5.3 \\
1.0 \\
1.7 \\
--\end{array}$ & $\begin{array}{l}0.50 \\
1.90 \\
1.10 \\
0.40 \\
0.40 \\
.-\end{array}$ & $\begin{array}{l}0.8 \\
8.5 \\
4.2 \\
0.6 \\
1.3 \\
--\end{array}$ & $\begin{array}{c}0.21 \\
0.76 \\
0.42 \\
0.18 \\
0.12 \\
--\end{array}$ & $\begin{array}{c}16 \\
150 \\
44 \\
12 \\
8.4 \\
--\end{array}$ & $\begin{array}{l}<1 \\
<1 \\
<1 \\
<1 \\
<1 \\
--\end{array}$ & $\begin{array}{l}21 \\
89 \\
30 \\
17 \\
16 \\
-\end{array}$ & $\begin{array}{l}<1 \\
<1 \\
<1 \\
<1 \\
<1 \\
--\end{array}$ & $\begin{array}{r}13 \\
220 \\
30 \\
8 \\
13 \\
--\end{array}$ \\
\hline 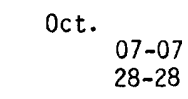 & $\begin{array}{l}24 \\
10\end{array}$ & $\begin{array}{l}1.8 \\
1.6\end{array}$ & $\begin{array}{l}0.20 \\
0.20\end{array}$ & $\begin{array}{l}1.5 \\
1.4\end{array}$ & $\begin{array}{l}0.22 \\
0.28\end{array}$ & $\begin{array}{l}21 \\
12\end{array}$ & $\begin{array}{l}<1 \\
<1\end{array}$ & $\begin{array}{l}70 \\
40\end{array}$ & $<1$ & $\begin{array}{r}18 \\
<10\end{array}$ \\
\hline Nov. $\begin{array}{l} \\
02-02 \\
02 \ldots \\
02 \ldots \\
02 \ldots \\
02 \ldots\end{array}$ & $\begin{array}{l}33 \\
40 \\
30 \\
27 \\
16\end{array}$ & $\begin{array}{l}2.0 \\
3.2 \\
2.0 \\
1.7 \\
1.3\end{array}$ & $\begin{array}{l}0.50 \\
0.70 \\
0.50 \\
0.50 \\
0.40\end{array}$ & $\begin{array}{l}1.5 \\
2.5 \\
1.5 \\
1.2 \\
0.9\end{array}$ & $\begin{array}{l}0.16 \\
0.25 \\
0.14 \\
0.14 \\
0.08\end{array}$ & $\begin{array}{l}22 \\
36 \\
20 \\
22 \\
12\end{array}$ & $\begin{array}{l}<1 \\
<1 \\
<1 \\
<1 \\
<1\end{array}$ & $\begin{array}{l}50 \\
40 \\
60 \\
70 \\
60\end{array}$ & $\begin{array}{l}2 \\
3 \\
2 \\
4 \\
1\end{array}$ & $\begin{array}{l}30 \\
30 \\
40 \\
50 \\
40\end{array}$ \\
\hline $\begin{array}{ll}\text { Feb. } & 1983 \\
09-09\end{array}$ & 14 & 0.9 & 0.20 & 0.7 & 0.17 & 5.4 & $!$ & 40 & 2 & 10 \\
\hline $15-15$ & 20 & 1.4 & 0.30 & 1.1 & 0.12 & 15 & $<1$ & 10 & 3 & 30 \\
\hline $\begin{array}{l}09-09 \\
10-11\end{array}$ & $\begin{array}{r}92 \\
4\end{array}$ & $\begin{array}{l}5.2 \\
1.4\end{array}$ & $\begin{array}{l}1.20 \\
0.10\end{array}$ & $\begin{array}{l}4.0 \\
1.3\end{array}$ & $\begin{array}{l}0.41 \\
0.20\end{array}$ & $\begin{array}{l}86 \\
9.4\end{array}$ & $\begin{array}{l}<1 \\
<1\end{array}$ & $\begin{array}{l}92 \\
39\end{array}$ & $\begin{array}{l}10 \\
<1\end{array}$ & $\begin{array}{r}120 \\
<3\end{array}$ \\
\hline $\begin{array}{l}\text { June } \\
\begin{aligned} & \\
& \\
& 14-14 \\
& 14 \ldots \\
& 14 \ldots \\
& 14 \ldots \\
& 14 \ldots\end{aligned}\end{array}$ & $\begin{array}{l}50 \\
89 \\
48 \\
33 \\
31\end{array}$ & $\begin{array}{l}3.0 \\
6.2 \\
2.3 \\
1.6 \\
1.1\end{array}$ & $\begin{array}{l}0.80 \\
2.00 \\
0.70 \\
0.40 \\
0.40\end{array}$ & $\begin{array}{l}2.2 \\
4.2 \\
1.6 \\
1.2 \\
0.7\end{array}$ & $\begin{array}{l}0.40 \\
1.40 \\
0.23 \\
0.28 \\
0.22\end{array}$ & $\begin{array}{l}35 \\
80 \\
32 \\
17 \\
17\end{array}$ & $\begin{array}{l}<1 \\
<1 \\
<1 \\
<1 \\
<1\end{array}$ & $\begin{array}{l}60 \\
55 \\
76 \\
53 \\
41\end{array}$ & $\begin{array}{r}4 \\
3 \\
3 \\
4 \\
12\end{array}$ & $\begin{array}{r}20 \\
26 \\
26 \\
8 \\
17\end{array}$ \\
\hline Aug. $08-08$ & 21 & 2.3 & 0.20 & 2.1 & 0.58 & 14 & $<1$ & 100 & $<1$ & 10 \\
\hline Sept. ${ }_{07-10}$ & 39 & 2.1 & 0.40 & 1.7 & 0.26 & 21 & $<1$ & 70 & 4 & 30 \\
\hline
\end{tabular}


Table 3.- - Water analyses of the inflow to Barton Creek Square Shopping Center--Continued

\begin{tabular}{|c|c|c|c|c|c|c|c|c|c|c|}
\hline Date & $\begin{array}{l}\text { Solids, } \\
\text { vola- } \\
\text { tile, } \\
\text { dis- } \\
\text { solved } \\
\text { (mg/L) }\end{array}$ & $\begin{array}{l}\text { Nitro- } \\
\text { gen, } \\
\text { total } \\
\text { (mg/L } \\
\text { as N) }\end{array}$ & $\begin{array}{c}\text { Nitro- } \\
\text { gen, } \\
\text { No2+NO3, } \\
\text { total } \\
(\mathrm{mg} / \mathrm{L} \\
\text { as } \mathrm{N}) \\
\end{array}$ & $\begin{array}{c}\text { Nitro- } \\
\text { gen, am- } \\
\text { monia }+ \\
\text { organic, } \\
\text { total } \\
(\mathrm{mg} / \mathrm{L} \\
\text { as } \mathrm{N}) \\
\end{array}$ & $\begin{array}{c}\text { Phos- } \\
\text { phorus, } \\
\text { total } \\
\text { (mg/L } \\
\text { as P) }\end{array}$ & $\begin{array}{l}\text { Carbon, } \\
\text { organic, } \\
\text { total } \\
(\mathrm{mg} / \mathrm{L} \\
\text { as C) }\end{array}$ & $\begin{array}{l}\text { Cadmium, } \\
\text { dis- } \\
\text { solved } \\
\text { ( } \mu \mathrm{g} / \mathrm{L})\end{array}$ & $\begin{array}{l}\text { Iron, } \\
\text { dis- } \\
\text { solved } \\
(\mu \mathrm{g} / \mathrm{L})\end{array}$ & $\begin{array}{l}\text { Lead, } \\
\text { dis- } \\
\text { sol ved } \\
(\mu g / L)\end{array}$ & $\begin{array}{l}\text { Zinc, } \\
\text { dis- } \\
\text { solved } \\
(\mu \mathrm{g} / \mathrm{L})\end{array}$ \\
\hline $\begin{array}{ll}\text { oct. } & 1983 \\
& 20-20\end{array}$ & 20 & 1.5 & 0.10 & 1.4 & 0.15 & 12 & $<1$ & 80 & 3 & 30 \\
\hline $\begin{array}{l}\text { Nov. } \\
22-23\end{array}$ & 24 & 2.3 & 0.30 & 2.0 & 0.31 & 22 & $<1$ & 22 & 2 & 24 \\
\hline $\begin{array}{l}\text { Dec. } \\
03-03\end{array}$ & 9 & 0.4 & 0.10 & 0.3 & 0.09 & 9.2 & $<1$ & 27 & 2 & 23 \\
\hline $\begin{aligned} \text { Feb. } & 1984 \\
& 26-26 \\
& 26 \ldots \\
& 26 \ldots \\
& 26 \ldots \\
& 26 \ldots\end{aligned}$ & $\begin{array}{r}24 \\
65 \\
6 \\
6 \\
8\end{array}$ & $\begin{array}{l}1.6 \\
3.9 \\
1.1 \\
0.7 \\
0.8\end{array}$ & $\begin{array}{l}0.50 \\
1.70 \\
0.20 \\
0.20 \\
0.30\end{array}$ & $\begin{array}{l}1.1 \\
2.2 \\
0.9 \\
0.5 \\
0.5\end{array}$ & $\begin{array}{l}0.20 \\
0.29 \\
0.18 \\
0.11 \\
0.08\end{array}$ & $\begin{array}{c}22 \\
53 \\
9.6 \\
6.3 \\
6.1\end{array}$ & $\begin{array}{l}<1 \\
<1 \\
<1 \\
<1 \\
<1\end{array}$ & $\begin{array}{l}19 \\
30 \\
28 \\
19 \\
16\end{array}$ & $\begin{array}{l}4 \\
3 \\
6 \\
3 \\
3\end{array}$ & $\begin{array}{r}33 \\
140 \\
8 \\
57 \\
30\end{array}$ \\
\hline Mar. $\begin{array}{r}04-04 \\
12-12 \\
23 \ldots\end{array}$ & $\begin{array}{r}20 \\
19 \\
8\end{array}$ & $\begin{array}{l}2.1 \\
1.6 \\
0.9\end{array}$ & $\begin{array}{l}0.50 \\
0.80 \\
0.30\end{array}$ & $\begin{array}{l}1.6 \\
0.8 \\
0.6\end{array}$ & $\begin{array}{l}0.17 \\
0.08 \\
0.09\end{array}$ & $\begin{array}{l}16 \\
11 \\
6.1\end{array}$ & $\begin{array}{l}<1 \\
<1 \\
<1\end{array}$ & $\begin{array}{l}17 \\
10 \\
23\end{array}$ & $\begin{array}{l}5 \\
6 \\
7\end{array}$ & $\begin{array}{l}29 \\
38 \\
14\end{array}$ \\
\hline $18-18$ & 27 & 3.0 & 0.50 & 2.5 & 0.35 & 30 & $<1$ & 45 & 1 & 34 \\
\hline June $04-05$ & 44 & 2.8 & 0.30 & 2.5 & 0.35 & 28 & $<1$ & 52 & 4 & 34 \\
\hline July $\begin{aligned} \\
24-24 \\
24 \ldots \\
24 \ldots \\
24 \ldots \\
24 \ldots\end{aligned}$ & $\begin{array}{r}35 \\
251 \\
18 \\
27 \\
22\end{array}$ & $\begin{array}{c}2.2 \\
11 \\
1.3 \\
1.1 \\
0.8\end{array}$ & $\begin{array}{l}0.50 \\
2.30 \\
0.30 \\
0.30 \\
0.20\end{array}$ & $\begin{array}{l}1.7 \\
9.0 \\
1.0 \\
0.8 \\
0.6\end{array}$ & $\begin{array}{l}0.35 \\
1.20 \\
0.24 \\
0.17 \\
0.15\end{array}$ & $\begin{array}{r}30 \\
150 \\
13 \\
16 \\
12\end{array}$ & $\begin{array}{l}<1 \\
<1 \\
<1 \\
<1 \\
<1\end{array}$ & $\begin{array}{r}80 \\
170 \\
30 \\
30 \\
60\end{array}$ & $\begin{array}{r}8 \\
11 \\
7 \\
5 \\
10\end{array}$ & $\begin{array}{r}60 \\
380 \\
30 \\
50 \\
40\end{array}$ \\
\hline Aug. $14-14$ & 16 & 1.0 & 0.50 & 0.5 & 0.09 & 11 & $<1$ & 16 & 6 & 47 \\
\hline
\end{tabular}


Table 4.--Water analyses of samples from section B of the ungaged drainage area at

\section{Barton Creek Square Shopping Center}

$[\mu \mathrm{S} / \mathrm{cm}$, microsiemens per centimeter at 25 degrees Celsius; $\mathrm{mg} / \mathrm{L}$, milligram per 1 iter; cols. $/ 100 \mathrm{~mL}$, colonies per 100 milliliters; $K$, non-ideal colony count; $\mu \mathrm{g} / \mathrm{L}$, inicrogram per liter]

\begin{tabular}{|c|c|c|c|c|c|c|c|c|c|c|}
\hline Date & \multicolumn{2}{|c|}{ Time } & $\begin{array}{l}\text { Spe- } \\
\text { cific } \\
\text { con- } \\
\text { duct- } \\
\text { ance } \\
(\mu S / c m)\end{array}$ & $\begin{array}{l}\text { Oxygen } \\
\text { demand, } \\
\text { chem- } \\
\text { ical } \\
\text { (nigh } \\
\text { level) } \\
\text { (mg/L) } \\
\end{array}$ & $\begin{array}{l}\text { Oxygen } \\
\text { demand, } \\
\text { bio- } \\
\text { chem- } \\
\text { ical, } \\
5 \text { day } \\
\text { (mg/L) }\end{array}$ & $\begin{array}{l}\text { Coli- } \\
\text { form, } \\
\text { fecal, } \\
0.7 \\
\text { UM-MF } \\
\text { (cols./ } \\
100 \mathrm{~mL}) \\
\end{array}$ & $\begin{array}{l}\text { Strep- } \\
\text { tococci } \\
\text { fecal, } \\
\mathrm{KF} \mathrm{Agar} \\
\text { (cols./ } \\
100 \mathrm{~mL} \text { ) }\end{array}$ & $\begin{array}{l}\text { Chio- } \\
\text { ride } \\
\text { dis- } \\
\text { solved } \\
\text { (mg/L) }\end{array}$ & $\begin{array}{l}\text { Solids, } \\
\text { residue } \\
\text { at } \\
180^{\circ} \mathrm{C}, \\
\text { dis- } \\
\text { solved } \\
(\mathrm{mg} / \mathrm{L})\end{array}$ & $\begin{array}{l}\text { Solids, } \\
\text { residue } \\
\text { at } \\
105^{\circ} \mathrm{C}, \\
\text { sus- } \\
\text { pended } \\
\text { (mg/L) }\end{array}$ \\
\hline Feb. $\begin{aligned} & 1984 \\
& 26 \ldots\end{aligned}$ & 0800 & & 183 & 90 & 7.7 & -- & -- & -- & 147 & 2,800 \\
\hline Mar. $23 .$. & 0937 & & 180 & 86 & 13 & -- & -- & -- & 131 & 3,000 \\
\hline \multirow[t]{5}{*}{ June } & 1700 & & 218 & 190 & 11 & 38,000 & $K 13,000$ & 13 & 153 & 2,360 \\
\hline & Date & $\begin{array}{l}\text { Nitro- } \\
\text { gen, } \\
\text { total } \\
\text { (mg/L } \\
\text { as } N \text { ) }\end{array}$ & $\begin{array}{l}\text { Nitro- } \\
\text { gen, } \\
\text { N02+NO3, } \\
\text { total } \\
\text { (mg/L } \\
\text { as N) }\end{array}$ & $\begin{array}{c}\text { Nitro- } \\
\text { gen, am- } \\
\text { monia }+ \\
\text { organic, } \\
\text { total } \\
(\mathrm{mg} / \mathrm{L} \\
\text { as } \mathrm{N}) \\
\end{array}$ & $\begin{array}{c}\text { Phos- } \\
\text { phorus, } \\
\text { total } \\
(\mathrm{mg} / \mathrm{L} \\
\text { as P) }\end{array}$ & $\begin{array}{l}\text { Carbon, } \\
\text { organic, } \\
\text { total } \\
(\mathrm{mg} / \mathrm{L} \\
\text { as C) }\end{array}$ & $\begin{array}{c}\text { Cadmium, } \\
\text { dis- } \\
\text { solved } \\
(\mu g / L)\end{array}$ & $\begin{array}{c}\text { Iron, } \\
\text { dis- } \\
\text { solved } \\
(\mu \mathrm{g} / \mathrm{L})\end{array}$ & $\begin{array}{l}\text { Lead, } \\
\text { dis- } \\
\text { solve } \\
(\mu g / L)\end{array}$ & $\begin{array}{l}\text { Zinc, } \\
\text { dis- } \\
\text { solve } \\
\text { l } \mu \mathrm{g} / \mathrm{L}\end{array}$ \\
\hline & $\begin{array}{l}1984 \\
26 \ldots\end{array}$ & 2.4 & 0.40 & 2.0 & 1.30 & 26 & $<1$ & 22 & 2 & 1 \\
\hline & $23 \ldots$ & 3.4 & 0.40 & 3.0 & 2.00 & 24 & $<1$ & 28 & 8 & 1 \\
\hline & $05 \ldots$ & 5.1 & 0.60 & 5.5 & 1.40 & 23 & $<1$ & 49 & 9 & 1 \\
\hline
\end{tabular}


Table 5.--Water analyses of samples from section $D$ of the ungaged drainage area at

Barton Creek Square Shopping Center

$[\mu \mathrm{S} / \mathrm{cm}$, microsiemens per centimeter at 25 degrees Celsius; mg/L, milligram per 1iter; cols. $/ 100 \mathrm{~mL}$, colonies per 100 milliliters; $K$, non-ideal colony count; $\mu \mathrm{g} / \mathrm{L}$, inicrogram per 1 iter]

\begin{tabular}{|c|c|c|c|c|c|c|c|c|c|c|c|}
\hline Date & \multicolumn{2}{|c|}{ Time } & $\begin{array}{l}\text { Spe- } \\
\text { cific } \\
\text { con- } \\
\text { duct- } \\
\text { ance } \\
(\mu \mathrm{S} / \mathrm{cm}) \\
\end{array}$ & $\begin{array}{l}\text { Oxygen } \\
\text { demand, } \\
\text { chem- } \\
\text { ical } \\
\text { (high } \\
\text { level) } \\
(\mathrm{mg} / \mathrm{L}) \\
\end{array}$ & $\begin{array}{l}\text { oxygen } \\
\text { demand, } \\
\text { bio- } \\
\text { chem- } \\
\text { ical, } \\
5 \text { day } \\
\text { (mg/L) }\end{array}$ & $\begin{array}{l}\text { Coli- } \\
\text { form, } \\
\text { fecal, } \\
0.7 \\
\text { UM-MF } \\
\text { (col s./ } \\
100 \mathrm{~mL} \text { ) } \\
\end{array}$ & $\begin{array}{l}\text { Strep- } \\
\text { tococci } \\
\text { fecal, } \\
\text { KF Agar } \\
\text { (col s.l } \\
100 \mathrm{~mL} \text { ) }\end{array}$ & $\begin{array}{l}\text { Chlo- } \\
\text { ride } \\
\text { dis- } \\
\text { solved } \\
\text { (ing/L) }\end{array}$ & $\begin{array}{l}\text { Solids, } \\
\text { residue } \\
\text { at } \\
180^{\circ} \mathrm{C}, \\
\text { dis- } \\
\text { solved } \\
\text { (mg/L) }\end{array}$ & $\begin{array}{l}\text { Solids, } \\
\text { residue } \\
\text { at } \\
105^{\circ} \mathrm{C}, \\
\text { sus- } \\
\text { pended } \\
\text { (mg/L) } \\
\end{array}$ & $\begin{array}{r}\text { Sol } \\
v c \\
\text { ti } \\
d \\
\text { sol } \\
\text { (ms }\end{array}$ \\
\hline Feb. $\begin{aligned} & 1984 \\
& 26 \ldots\end{aligned}$ & \multicolumn{2}{|c|}{0803} & 219 & 110 & 11 & -- & -- & - & 134 & 1,240 & \\
\hline $18 \ldots$ & \multicolumn{2}{|c|}{1300} & 261 & 200 & 36 & 70,000 & 72,000 & 11 & 221 & 705 & \\
\hline $\begin{array}{l}\text { June } \\
\\
\end{array}$ & \multicolumn{2}{|c|}{1645} & 111 & 230 & 11 & 23,000 & 54,000 & 23 & 78 & 7,100 & \\
\hline \multirow[t]{4}{*}{ July } & \multicolumn{2}{|c|}{0820} & 167 & 81 & -- & $K 34,000$ & 5,100 & $<0.2$ & 118 & 989 & \\
\hline & Date & $\begin{array}{l}\text { Nitro- } \\
\text { gen, } \\
\text { total } \\
\text { (mg/L } \\
\text { as N) }\end{array}$ & $\begin{array}{c}\text { Nitro- } \\
\text { gen, } \\
\text { N02+N03, } \\
\text { total } \\
\text { (mg/L } \\
\text { as } N)\end{array}$ & $\begin{array}{c}\text { Nitro- } \\
\text { gen, am- } \\
\text { monia }+ \\
\text { organic, } \\
\text { total } \\
(\mathrm{mg} / \mathrm{L} \\
\text { as } \mathrm{N}) \\
\end{array}$ & $\begin{array}{c}\text { Phos- } \\
\text { phorus, } \\
\text { total } \\
(\mathrm{mg} / \mathrm{L} \\
\text { as } \mathrm{P})\end{array}$ & $\begin{array}{c}\text { Carbon, } \\
\text { organic, } \\
\text { total } \\
(\mathrm{mg} / \mathrm{L} \\
\text { as C) }\end{array}$ & $\begin{array}{c}\text { Cadmium, } \\
\text { dis- } \\
\text { solved } \\
(\mu \mathrm{g} / \mathrm{L})\end{array}$ & $\begin{array}{c}\text { Iron, } \\
\text { dis- } \\
\text { solved } \\
(\mu g / L)\end{array}$ & $\begin{array}{l}\text { Lead, } \\
\text { dis- } \\
\text { solve } \\
\text { ( } \mu \mathrm{g} / \mathrm{L}\end{array}$ & \multicolumn{2}{|c|}{$\begin{array}{c}\text { Zinc, } \\
\text { dis- } \\
\text { solvec } \\
(\mu \mathrm{g} / \mathrm{L})\end{array}$} \\
\hline & $\begin{array}{l}1984 \\
26 . .\end{array}$ & 3.0 & 0.39 & 2.6 & 0.60 & 33 & $<1$ & 80 & & $<1$ & 10 \\
\hline & $18 \ldots$ & 3.9 & 0.90 & 3.0 & 0.40 & 46 & $<1$ & 58 & & 2 & 13 \\
\hline & $05 \ldots$ & 9.3 & 0.30 & 9.0 & 0.60 & 47 & $<1$ & 57 & & $<1$ & 28 \\
\hline July & $24 \ldots$ & 2.5 & 0.50 & 2.0 & 0.80 & 20 & -- & -- & & -- & -- \\
\hline
\end{tabular}


Table 6.-- Water analyses of the outflow at Barton Creek Square Shopping Center

$\left[\mathrm{ft}^{3} / \mathrm{s}\right.$, cuibic foot per second; $\mu \mathrm{S} / \mathrm{cm}$, microsienens per centineter at 25 degrees Celsius; mg/L, milligram per liter; cols. $/ 100 \mathrm{~mL}$, colonies per 100 milliliters; $K$, non-ideal colony count; $[\mathrm{g} / \mathrm{L}$, microgram per $7 i$ ter]

38155370 Skunk Hollow Creek below Pond 1 at Austin, Texas

\begin{tabular}{|c|c|c|c|c|c|c|c|c|c|c|}
\hline Date & Time & $\begin{array}{l}\text { sean } \\
\text { sample } \\
\text { dis- } \\
\text { charge } \\
\left(\mathrm{ft}^{3} / \mathrm{s}\right)\end{array}$ & $\begin{array}{l}\text { Instan- } \\
\text { taneous } \\
\text { sample } \\
\text { dis- } \\
\text { charge } \\
\left(\mathrm{ft}^{3} / \mathrm{s}\right)\end{array}$ & $\begin{array}{l}\text { Spe- } \\
\text { cific } \\
\text { con- } \\
\text { duct- } \\
\text { ance } \\
(\mu \mathrm{S} / \mathrm{cm})\end{array}$ & $\begin{array}{l}\text { Jxyen } \\
\text { demand, } \\
\text { chem- } \\
\text { ical } \\
\text { (nigh } \\
\text { level) } \\
\text { (mg/L) }\end{array}$ & $\begin{array}{l}\text { oxygen } \\
\text { deinand, } \\
\text { bio- } \\
\text { chem- } \\
\text { ical, } \\
5 \text { day } \\
\text { (my/L) }\end{array}$ & $\begin{array}{l}\text { Coli- } \\
\text { form, } \\
\text { fecal, } \\
0.7 \\
\text { UM-MF } \\
\text { (cols.! } \\
100 \mathrm{~mL} \text { ) }\end{array}$ & $\begin{array}{l}\text { Strep- } \\
\text { tococci } \\
\text { fecal, } \\
\text { KF Agar } \\
\text { (cols./ } \\
100 \mathrm{~mL} \text { ) }\end{array}$ & $\begin{array}{l}\text { Sotids, } \\
\text { residue } \\
\text { at } \\
180^{\circ} \mathrm{C}, \\
\text { dis- } \\
\text { solved } \\
(\mathrm{mg} / \mathrm{L})\end{array}$ & $\begin{array}{l}\text { soTids, } \\
\text { residue } \\
\text { at } \\
105^{\circ} \mathrm{C}, \\
\text { sus- } \\
\text { pended } \\
\text { (mg/L) }\end{array}$ \\
\hline $\begin{array}{c}\text { Sept. } 1982 \\
03-04 \\
03 \ldots \\
03 \ldots \\
03 \ldots \\
04 \ldots\end{array}$ & $\begin{array}{l}2210-0510 \\
2225 \\
2310 \\
2355 \\
0055\end{array}$ & $\begin{array}{l}0.41 \\
-- \\
-- \\
--\end{array}$ & $\begin{array}{l}-. \\
1.5 \\
1.1 \\
0.65 \\
0.35\end{array}$ & $\begin{array}{l}113 \\
434 \\
364 \\
402 \\
388\end{array}$ & $\begin{array}{l}210 \\
190 \\
310 \\
210 \\
230\end{array}$ & $\begin{array}{l}35 \\
33 \\
39 \\
35 \\
37\end{array}$ & $\begin{array}{l}-- \\
-- \\
-- \\
--\end{array}$ & $\begin{array}{r}2,400 \\
8,800 \\
-\because \\
4,600 \\
4,300\end{array}$ & $\begin{array}{l}352 \\
355 \\
342 \\
340 \\
338\end{array}$ & $\begin{array}{r}117 \\
198 \\
180 \\
53 \\
27\end{array}$ \\
\hline $\begin{array}{l}20 \ldots \\
20-20 \\
20 \ldots \\
20 \ldots \\
20 \ldots \\
20 \ldots\end{array}$ & $\begin{array}{l}0001 \\
0001-2400 \\
0045 \\
0108 \\
0245 \\
0800\end{array}$ & $\begin{array}{l}- \\
1.3 \\
-- \\
-- \\
--\end{array}$ & $\begin{array}{c}1.3 \\
-- \\
3.1 \\
3.1 \\
2.7 \\
1.8\end{array}$ & $\begin{array}{l}360 \\
151 \\
257 \\
229 \\
152 \\
130\end{array}$ & $\begin{array}{r}120 \\
42 \\
40 \\
--\quad \\
23 \\
35\end{array}$ & $\begin{array}{r}14 \\
3.3 \\
6.0 \\
-- \\
2.4 \\
2.1\end{array}$ & $\begin{array}{r}33,000 \\
8,400 \\
6,400 \\
\times 5,000 \\
5,400 \\
17,000\end{array}$ & $\begin{array}{r}46,000 \\
19,000 \\
8,800 \\
\times 7,800 \\
9,200 \\
14,000\end{array}$ & $\begin{array}{r}265 \\
113 \\
1315 \\
-\quad \\
105 \\
92\end{array}$ & $\begin{array}{r}200 \\
50 \\
67 \\
-\quad \\
78 \\
42\end{array}$ \\
\hline oct. $\begin{aligned} 07-08 \\
\\
23-29\end{aligned}$ & $\begin{array}{l}1635-2400 \\
2223-2400\end{array}$ & $\begin{array}{l}0.49 \\
0.86\end{array}$ & -- & $\begin{array}{l}158 \\
133\end{array}$ & $\begin{array}{l}24 \\
56\end{array}$ & $\begin{array}{l}2.4 \\
3.2\end{array}$ & $\begin{array}{r}20,000 \\
2,000\end{array}$ & $\begin{array}{r}11,000 \\
3,000\end{array}$ & $\begin{array}{r}117 \\
92\end{array}$ & $\begin{array}{l}46 \\
34\end{array}$ \\
\hline $\begin{array}{l}\text { Nov. } \\
\begin{array}{l}02-03 \\
02 \ldots \\
02 \ldots \\
02 \ldots \\
02 \ldots\end{array}\end{array}$ & $\begin{array}{l}1450-2400 \\
1451 \\
1536 \\
1705 \\
1906\end{array}$ & $\begin{array}{l}0.93 \\
-- \\
-- \\
-- \\
--\end{array}$ & $\begin{array}{l}-- \\
0.35 \\
1.5 \\
1.2 \\
1.2\end{array}$ & $\begin{array}{l}143 \\
165 \\
157 \\
145 \\
133\end{array}$ & $\begin{array}{l}53 \\
58 \\
58 \\
57 \\
49\end{array}$ & $\begin{array}{l}4.4 \\
8.3 \\
7.6 \\
5.8 \\
4.2\end{array}$ & $\begin{array}{r}5,000 \\
k 7,400 \\
10,000 \\
4,900 \\
4,800\end{array}$ & $\begin{array}{r}9,600 \\
8,000 \\
K 6,400 \\
2,200 \\
4,200\end{array}$ & $\begin{array}{l}112 \\
125 \\
122 \\
114 \\
104\end{array}$ & $\begin{array}{r}32 \\
158 \\
42 \\
26 \\
40\end{array}$ \\
\hline Feb. $\begin{array}{ll}1983 \\
09-10\end{array}$ & $0955-2400$ & 0.53 & -- & 145 & 19 & 1.3 & 4,400 & 2,500 & 96 & 68 \\
\hline Mar. $15-15$ & $1340-2400$ & 0.53 & -- & 132 & 32 & 1.1 & $K 560$ & 3,000 & 94 & 48 \\
\hline $\begin{array}{l}09-09 \\
10-11 \\
11-13\end{array}$ & $\begin{array}{l}1415-2123 \\
2315-0800 \\
0801-2400\end{array}$ & $\begin{array}{l}0.33 \\
7.0 \\
0.53\end{array}$ & $\begin{array}{l}-- \\
--\end{array}$ & $\begin{array}{l}283 \\
144 \\
198\end{array}$ & $\begin{array}{r}150 \\
79 \\
32\end{array}$ & $\begin{array}{c}13 \\
3.3 \\
1.3\end{array}$ & $\begin{array}{r}2,200 \\
18,000 \\
2,000\end{array}$ & $\begin{array}{r}5,600 \\
40,000 \\
25,000\end{array}$ & $\begin{array}{l}249 \\
102 \\
119\end{array}$ & $\begin{array}{r}40 \\
1,250 \\
459\end{array}$ \\
\hline $\begin{array}{l}\text { Jurle } \\
\\
14-15 \\
14 \ldots \\
14 \ldots \\
15 \ldots \\
15 \ldots\end{array}$ & $\begin{array}{l}1815-2400 \\
1820 \\
1940 \\
0205 \\
0820\end{array}$ & $\begin{array}{l}0.43 \\
-- \\
-- \\
-- \\
--\end{array}$ & $\begin{array}{l}-- \\
0.23 \\
0.93 \\
0.53 \\
0.39\end{array}$ & $\begin{array}{l}255 \\
257 \\
318 \\
233 \\
227\end{array}$ & $\begin{array}{r}45 \\
100 \\
45 \\
41 \\
37\end{array}$ & $\begin{array}{c}3.8 \\
17 \\
5.3 \\
3.5 \\
3.5\end{array}$ & $\begin{array}{r}51,000 \\
74,000 \\
9,600 \\
76,000 \\
110,000\end{array}$ & $\begin{array}{l}23,000 \\
48,000 \\
38,000 \\
10,000 \\
17,000\end{array}$ & $\begin{array}{l}178 \\
219 \\
221 \\
161 \\
146\end{array}$ & $\begin{array}{r}40 \\
221 \\
68 \\
29 \\
22\end{array}$ \\
\hline Aug. $08-10$ & $1250-2400$ & 1.4 & $-\cdot$ & 138 & 54 & 1.4 & 53,000 & 93,000 & 92 & 1,150 \\
\hline Sept. & $1550-2400$ & 0.7 & -- & 153 & 56 & 2.9 & 24,000 & 9,900 & 114 & 801 \\
\hline Oct. $20-21$ & $1450-2400$ & 0.39 & -- & 135 & 50 & 4.9 & 130,000 & 100,000 & 101 & 28 \\
\hline Nov. $23-25$ & $0001-2400$ & 0.18 & -- & 192 & 23 & 2.9 & $K 3,700$ & $\mathrm{k} 11,000$ & 125 & 26 \\
\hline Dec. $03-06$ & $0001-2400$ & 0.28 & -- & 212 & 29 & 1.3 & 18,000 & 7,500 & 136 & 94 \\
\hline Feb. $\begin{aligned} & 1934 \\
& 26-23 \\
& 26 \ldots \\
& 25 \ldots \\
& 26 \ldots \\
& 27 \ldots\end{aligned}$ & $\begin{array}{l}0800-2400 \\
0340 \\
1310 \\
2010 \\
0210\end{array}$ & $\begin{array}{l}0.2 \\
-- \\
-- \\
--\end{array}$ & $\begin{array}{l}-- \\
1.5 \\
0.65 \\
0.23 \\
0.12\end{array}$ & $\begin{array}{l}197 \\
272 \\
170 \\
146 \\
144\end{array}$ & $\begin{array}{l}21 \\
30 \\
18 \\
17 \\
16\end{array}$ & $\begin{array}{l}2.6 \\
5.1 \\
3.2 \\
2.0 \\
1.3\end{array}$ & $\begin{array}{r}K 560 \\
K 900 \\
K 350 \\
400 \\
K 640\end{array}$ & $\begin{array}{r}3,300 \\
\mathrm{~K} 1,800 \\
2,400 \\
1,600 \\
1,200\end{array}$ & $\begin{array}{r}121 \\
184 \\
117 \\
102 \\
96\end{array}$ & $\begin{array}{l}33 \\
71 \\
26 \\
24 \\
17\end{array}$ \\
\hline $\begin{array}{l}\text { Har. } \\
12-13 \\
12-13\end{array}$ & $\begin{array}{l}2020-24 J 0 \\
0125-2400\end{array}$ & $\begin{array}{l}0.17 \\
0.45\end{array}$ & -- & $\begin{array}{l}185 \\
166\end{array}$ & $\begin{array}{c}21 \\
21 \\
-38-\end{array}$ & $\begin{array}{l}2.0 \\
1.8\end{array}$ & $\begin{array}{r}K 59 \\
K 340\end{array}$ & $\begin{array}{l}4,200 \\
2,900\end{array}$ & $\begin{array}{l}119 \\
111\end{array}$ & $\begin{array}{l}20 \\
10\end{array}$ \\
\hline
\end{tabular}


Table 6.--Nater analyses of the c.11tflow at Barton Creek Square Shopping Center--Continued

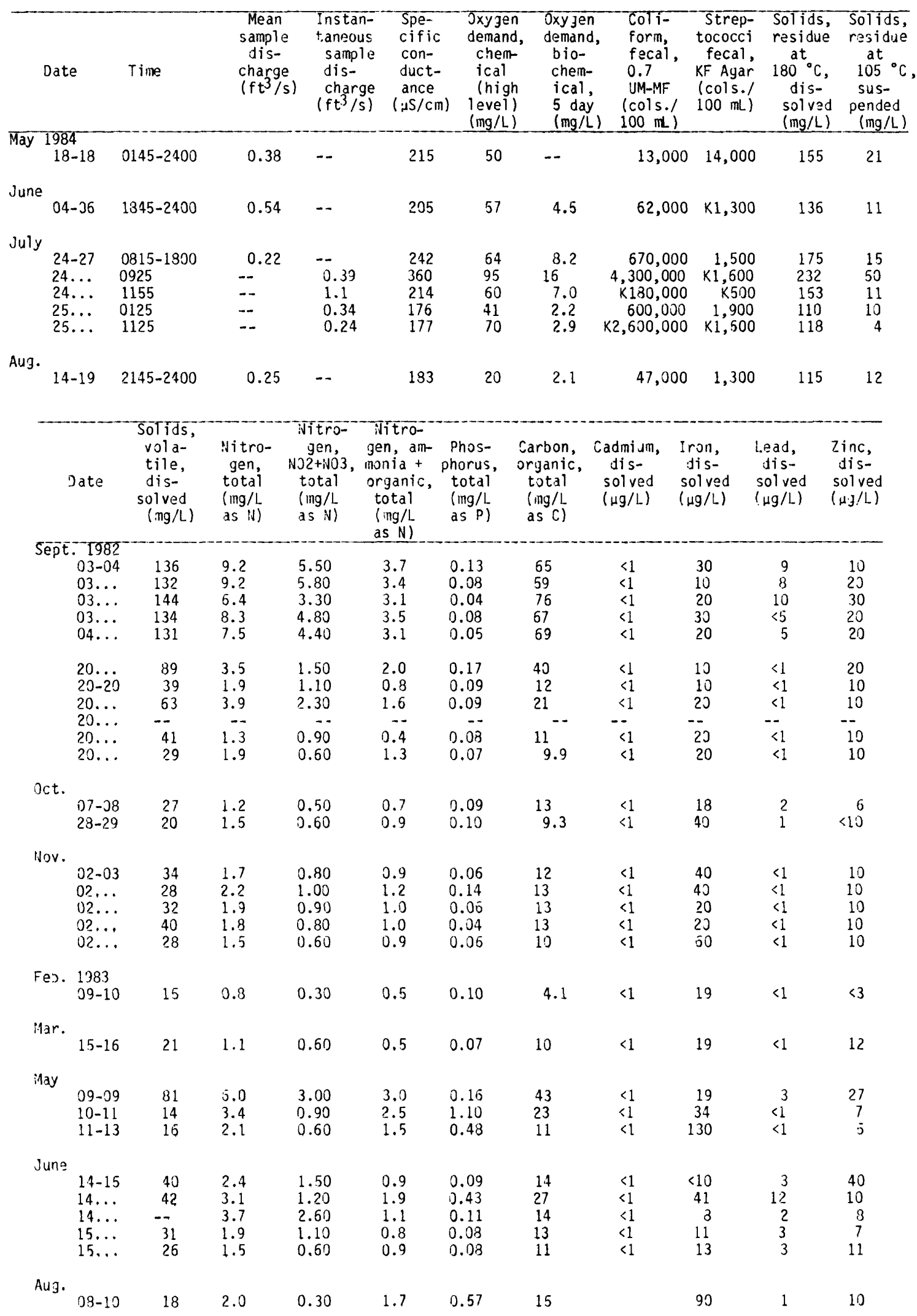


Table 6.--Water analyses of the outflow at Barton Creek Square Shopping Center--Continued

\begin{tabular}{|c|c|c|c|c|c|c|c|c|c|c|}
\hline Date & $\begin{array}{l}\text { Solids, } \\
\text { vola- } \\
\text { tile, } \\
\text { dis- } \\
\text { solved } \\
\text { (mg/L) }\end{array}$ & $\begin{array}{l}\text { Nitro- } \\
\text { gen, } \\
\text { total } \\
\text { (mg/L } \\
\text { as } N \text { ) }\end{array}$ & $\begin{array}{l}\text { Nitro- } \\
\text { gen, } \\
\text { No2+N03, } \\
\text { total } \\
\text { (mg/L } \\
\text { as N) }\end{array}$ & $\begin{array}{l}\text { Nitro- } \\
\text { gen, am- } \\
\text { monia }+ \\
\text { organic, } \\
\text { total } \\
\text { (mg/L } \\
\text { as } N \text { ) }\end{array}$ & $\begin{array}{l}\text { Phos- } \\
\text { phorus, } \\
\text { total } \\
\text { (mg/L } \\
\text { as P) }\end{array}$ & $\begin{array}{c}\text { Carbon, } \\
\text { organic, } \\
\text { total } \\
(\mathrm{mg} / \mathrm{L} \\
\mathrm{ds} \mathrm{C})\end{array}$ & $\begin{array}{l}\text { Cadmium, } \\
\text { dis- } \\
\text { solved } \\
(\mu \mathrm{g} / \mathrm{L})\end{array}$ & $\begin{array}{l}\text { Iron, } \\
\text { dis- } \\
\text { solved } \\
(\mu \mathrm{g} / \mathrm{L})\end{array}$ & $\begin{array}{l}\text { Lead, } \\
\text { dis- } \\
\text { solved } \\
(\mu \mathrm{g} / \mathrm{L})\end{array}$ & $\begin{array}{l}\text { Zinc, } \\
\text { dis- } \\
\text { solved } \\
(\mu \mathrm{H} / \mathrm{L})\end{array}$ \\
\hline $\begin{array}{r}\text { Sept. } 1983 \\
07-11\end{array}$ & 29 & 1.6 & 0.40 & 1.2 & 0.14 & 14 & $<1$ & 30 & $<1$ & 10 \\
\hline oct. $20-21$ & 23 & 1.1 & 0.20 & 0.9 & 0.17 & 11 & $<1$ & 50 & 3 & 60 \\
\hline Nov. $23-25$ & 21 & 1.5 & 0.80 & 0.7 & 0.08 & 7.0 & $<1$ & 10 & 2 & 11 \\
\hline $\begin{array}{l}\text { Dec. } \\
03-05\end{array}$ & 13 & 0.8 & 0.30 & 0.5 & 0.12 & 6.4 & $<1$ & 13 & 1 & 13 \\
\hline $\begin{aligned} & \text { Feb. } 1984 \\
& 25-28 \\
& 26 \ldots \\
& 25 \ldots \\
& 26 \ldots \\
& 27 \ldots\end{aligned}$ & $\begin{array}{l}16 \\
32 \\
17 \\
15 \\
12\end{array}$ & $\begin{array}{l}1.4 \\
3.9 \\
0.8 \\
0.8 \\
0.7\end{array}$ & $\begin{array}{l}1.10 \\
3.10 \\
0.50 \\
0.50 \\
0.50\end{array}$ & $\begin{array}{l}0.3 \\
0.8 \\
0.3 \\
0.3 \\
0.2\end{array}$ & $\begin{array}{l}0.15 \\
0.13 \\
0.10 \\
0.11 \\
0.10\end{array}$ & $\begin{array}{l}5.5 \\
9.5 \\
4.8 \\
4.5 \\
4.0\end{array}$ & $\begin{array}{l}<1 \\
<1 \\
<1 \\
<1 \\
<1\end{array}$ & $\begin{array}{l}23 \\
15 \\
20 \\
19 \\
19\end{array}$ & $\begin{array}{r}<1 \\
2 \\
1 \\
? \\
<1\end{array}$ & $\begin{array}{l}11 \\
16 \\
10 \\
11 \\
11\end{array}$ \\
\hline Mar. $\begin{array}{r}04-07 \\
12-13\end{array}$ & $\begin{array}{l}17 \\
19\end{array}$ & $\begin{array}{l}1.1 \\
1.5\end{array}$ & $\begin{array}{l}0.80 \\
0.80\end{array}$ & $\begin{array}{l}0.3 \\
0.7\end{array}$ & $\begin{array}{l}0.05 \\
0.07\end{array}$ & $\begin{array}{l}5.2 \\
5.0\end{array}$ & $\begin{array}{l}<1 \\
<1\end{array}$ & $\begin{array}{l}14 \\
12\end{array}$ & $\begin{array}{r}<1 \\
3\end{array}$ & $\begin{array}{l}10 \\
16\end{array}$ \\
\hline $18-1.3$ & 41 & 3.2 & 2.40 & 0.8 & 0.09 & 17 & $<1$ & 18 & 3 & 12 \\
\hline $\begin{array}{l}\text { June } \\
04-05\end{array}$ & 40 & 2.7 & 1.50 & 1.1 & 0.07 & 12 & $<1$ & 9 & $<1$ & 15 \\
\hline $\begin{array}{l}\text { July } \\
\\
24-27 \\
24 \ldots \\
24 \ldots \\
25 \ldots \\
25 \ldots\end{array}$ & $\begin{array}{l}56 \\
70 \\
45 \\
29 \\
27\end{array}$ & $\begin{array}{l}5.6 \\
7.5 \\
3.6 \\
1.1 \\
0.6\end{array}$ & $\begin{array}{l}4.20 \\
5.30 \\
2.50 \\
0.50 \\
0.20\end{array}$ & $\begin{array}{l}1.4 \\
2.2 \\
1.1 \\
0.5 \\
0.4\end{array}$ & $\begin{array}{l}0.08 \\
0.14 \\
0.08 \\
0.07 \\
0.11\end{array}$ & $\begin{array}{l}19 \\
24 \\
1.3 \\
13 \\
13\end{array}$ & $\begin{array}{l}<1 \\
<1 \\
<1 \\
<1 \\
<1\end{array}$ & $\begin{array}{l}30 \\
50 \\
40 \\
50 \\
40\end{array}$ & $\begin{array}{l}3 \\
3 \\
2 \\
2 \\
2\end{array}$ & $\begin{array}{l}10 \\
10 \\
10 \\
20 \\
10\end{array}$ \\
\hline Aug. $17-19$ & 18 & $1 . ?$ & 0.80 & 0.4 & 0.04 & 7.0 & $<1$ & 9 & $<1$ & 13 \\
\hline
\end{tabular}


$100 \mathrm{~mL}$ (colonies per $100 \mathrm{milliliters)}$ and exceeded $100,000 \mathrm{cols} . / 100 \mathrm{~mL}$ in 5 of the 22 storms analyzed. Discharge-weighted fecal-coliform densities in the outflow ranged from 59 to $670,000 \mathrm{cols} . / 100 \mathrm{~mL}$ and exceeded $100,000 \mathrm{cols} . / 100$ $\mathrm{mL}$ on only two occasions. Discharge-weighted densities of fecal-streptococci bacteria in the inflow ranged from 5,000 to 220,000 and exceeded 100,000 cols./ $100 \mathrm{~mL}$ on four occasions. Discharge-weighted densities of fecal streptococci in the outflow ranged from 1,300 to $100,000 \mathrm{cols} . / 100 \mathrm{~mL}$. The reduction of discharge-weighted densities of fecal-coliform and fecal-streptococci bacteria in the outflow probably are attributable to deposition of bacteria-laden sediment particles, removal of bacteria as water flowed through the filter, and natural die-off.

The fecal coliform to fecal streptococci ratio of the discharge-weighted densities in the inflow was less than 4.0 for all but four storms. Ratios greater than 4 generally indicate the source to be human, and ratios less than 0.7 generally indicate an animal source. The ratio exceeded 4.0 on the first storm and 1 ast three storms. The fecal col iform to fecal streptococci ratio during the last three storms analyzed exceeded 20. Ratios of fecal coliform to fecal streptococci in the outflow exceeded 4.0 only during the June $4-6$, and July 24-27, 1984, storms.

\section{Biochemical oxygen demand}

Discharge-weighted concentrations of biochemical oxygen demand (BOD) were substantially larger in the inflow than in the outflow for most of the sotrms (fig. 19). The May 10, 1983 storm, in which pond outflow overtopped the drop outlet structure, showed discharge-weighted concentrtions higher in the outflow than in the inflow. Discharge-weighted BOD concentrations in the inflow ranged from 3.3 to $82 \mathrm{mg} / \mathrm{L}$ (milligrams per 1 iter) and were 1 ess than $20 \mathrm{mg} / \mathrm{L}$ for all but four storms. Discharge-weighted BOD concentrations in the outflow ranged from 1.1 to $35 \mathrm{mg} / \mathrm{L}$; however, concentrations exceeded $10 \mathrm{mg} / \mathrm{L}$ on only two occasions. Discharge-weighted BOD concentrations were smaller in the outflow than in the inflow probably because of deposition of suspended biodegradable organic matter, sorption of biodegradable organic matter as water passed through the filter system, and biochemical oxidation of organic matter during residence in the pond and filter system.

\section{Chemical oxygen demand}

Discharge-weighted concentrations of chemical oxygen demand (COD) also were substantially 1 arger in the inflow discharge than in the outflow (fig. 19). Discharge-weighted COD concentrations in the inflow ranged from 31 to 760 $\mathrm{mg} / \mathrm{L}$. Discharge-weighted average COD concentrations in the outflow ranged from 19 to $210 \mathrm{mg} / \mathrm{L}$ and only exceeded $100 \mathrm{mg} / \mathrm{L}$ on two occasions. Discharge-weighted COD concentrations in the outflow exceeded inflow concentrations only during the May 10-11, 1983, storm when the pond outflow spilled over the drop outlet, and on July 24, 1984. Discharge-weighted COD concentrations were less in the outflow because of deposition of oxidizable matter, removal of oxidizable matter through the filter, and chemical and biochemical oxidation of matter during residence in in the pond. 

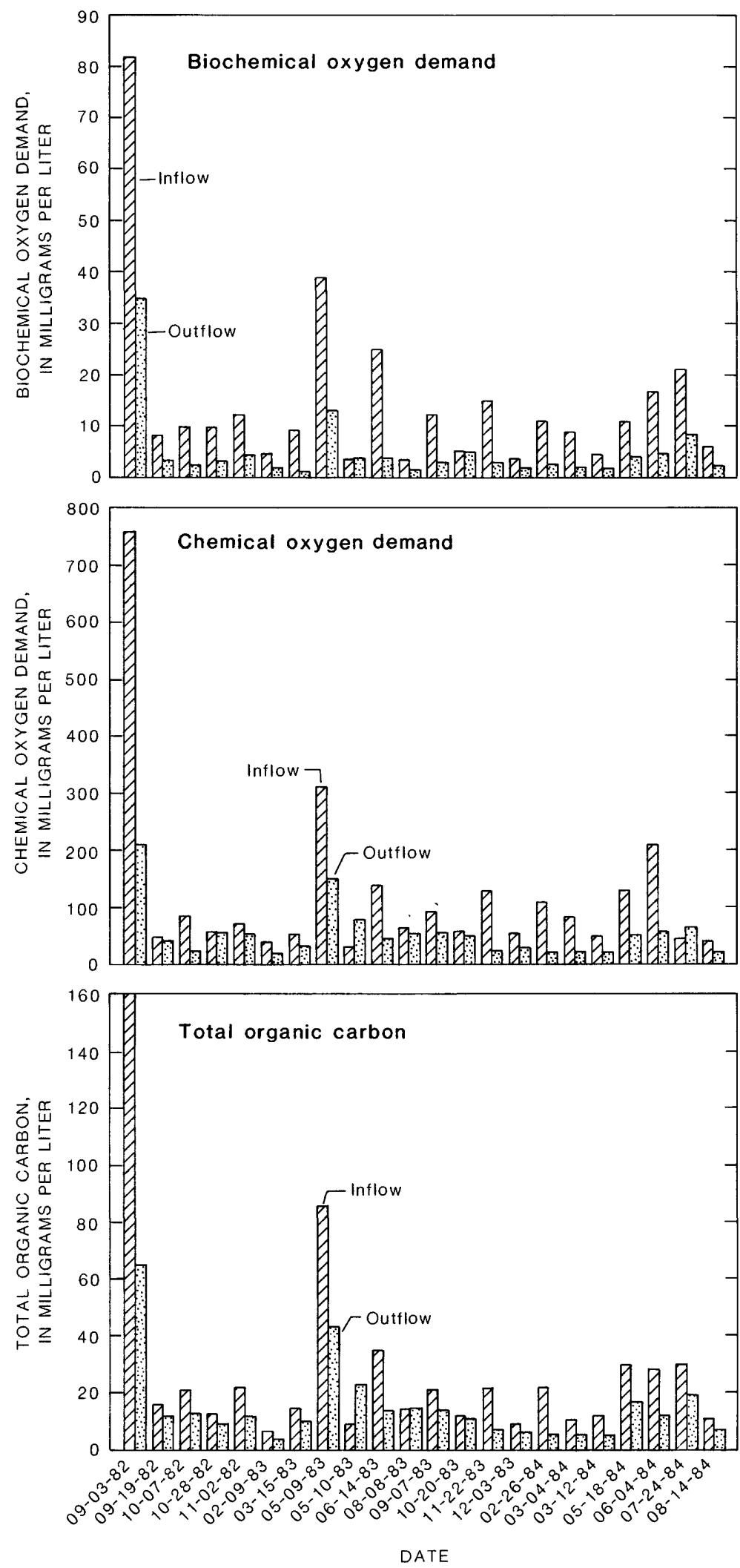

Figure 19.--Discharge-weighted concentrations of biochemical oxygen demand, chemical oxygen demand, and total organic carbon in the inflow and outflow of Pond 1 at Barton Creek Square Shopping Center. 
Discharge-weighted concentrations of total organic carbon (TOC) also were 1 arger in the inflow discharge than in the outflow (fig. 19) except for two of the storms in which pond outflow overtopped the outlet structure. Dischargeweighted TOC concentrations in the inflow ranged from 6.9 to $160 \mathrm{mg} / \mathrm{L}$ and only exceeded $35 \mathrm{mg} / \mathrm{L}$ on two occasions. Discharge-weighted TOC concentrations in the outflow ranged from 4.1 to $65 \mathrm{mg} / \mathrm{L}$ and only exceeded $20 \mathrm{mg} / \mathrm{L}$ on three occasions. Much of the TOC probably was removed through deposition, oxidation, filtration, and adsorption.

Suspended, dissolved, and volatile dissolved solids

The discharge-weighted concentrations of suspended solids varied greatly throughout the study period because of varying intensities of rainfall and different percentages of vegetated cover in sections B, C, and D (fig. 2). Early in the study, the slopes and banks around the pond were completely unvegetated and were covered with topsoil. During high-intensity rainfall, topsoil was washed directly into the pond. Samples of runoff from sections $B$ and $D I$ ate in the study indicated that concentrations of suspended solids from the ungaged areas were substantially 1 arger than that coming from the gaged area of the mall and parking lots (tables 4-5). Sampled concentrations of suspended sol ids from section $B$ of the ungaged area ranged from 2,360 to $3,000 \mathrm{mg} / \mathrm{L}$ (table 4). Sampled suspended-solids concentrations from section $D$ ranged from 705 to $7,100 \mathrm{mg} / \mathrm{L}$ (table 5). Al though the amount of ungaged inflow for most storms was relatively small compared to the measured inflow, the 1 arge concentrations of suspended solids in the unmeasured inflow resulted in substantially larger discharge-weighted concentrations of suspended solids in the pond than was actually sampled at the inflow station. This occurred because the runoff at the inflow gaging station is largely from an impervious area, which would contribute less suspended solids than would an unvegetated area.

The discharge-weighted concentrations of suspended solids in the inflow ranged from 11 to $893 \mathrm{mg} / \mathrm{L}$, whereas those in the outflow ranged from 11 to 1,250 $\mathrm{mg} / \mathrm{L}$ (fig. 20). The storm events of May 10-11, August 8, and September 7-10, 1983, were of such intensity that the inflow filled the pond and spilled through the drop outlet directly into the receiving stream. During these three storms, the majority of the inflow did not pass through the pond filter, and the concentrations of the discharge-weighted suspended solids in the outflow exceeded those of the inflow. During all other storms, the discharge-weighted concentrations in the outflow generally were much smaller than in the inflow.

With the exception of the first storm analyzed, the discharge-weighted concentrations of dissolved solids in the inflow were less than concentrations in the outflow (fig. 20). The discharge-weighted dissolved-solids concentrations in the inflow ranged from 47 to $410 \mathrm{mg} / \mathrm{L}$, whereas those in the outflow ranged from 92 to $352 \mathrm{mg} / \mathrm{L}$. A possible explanation for the increase in discharge-weighted concentrations of dissolved solids in the outflow is mineralization of organic matter deposited on the filter and dissolution of evaporites and dust from the pond bed and filter system. During the course of the study, the pond and filter system became clogged with silt and clay. This increased the detention time of the inflow water and allowed more time for the 

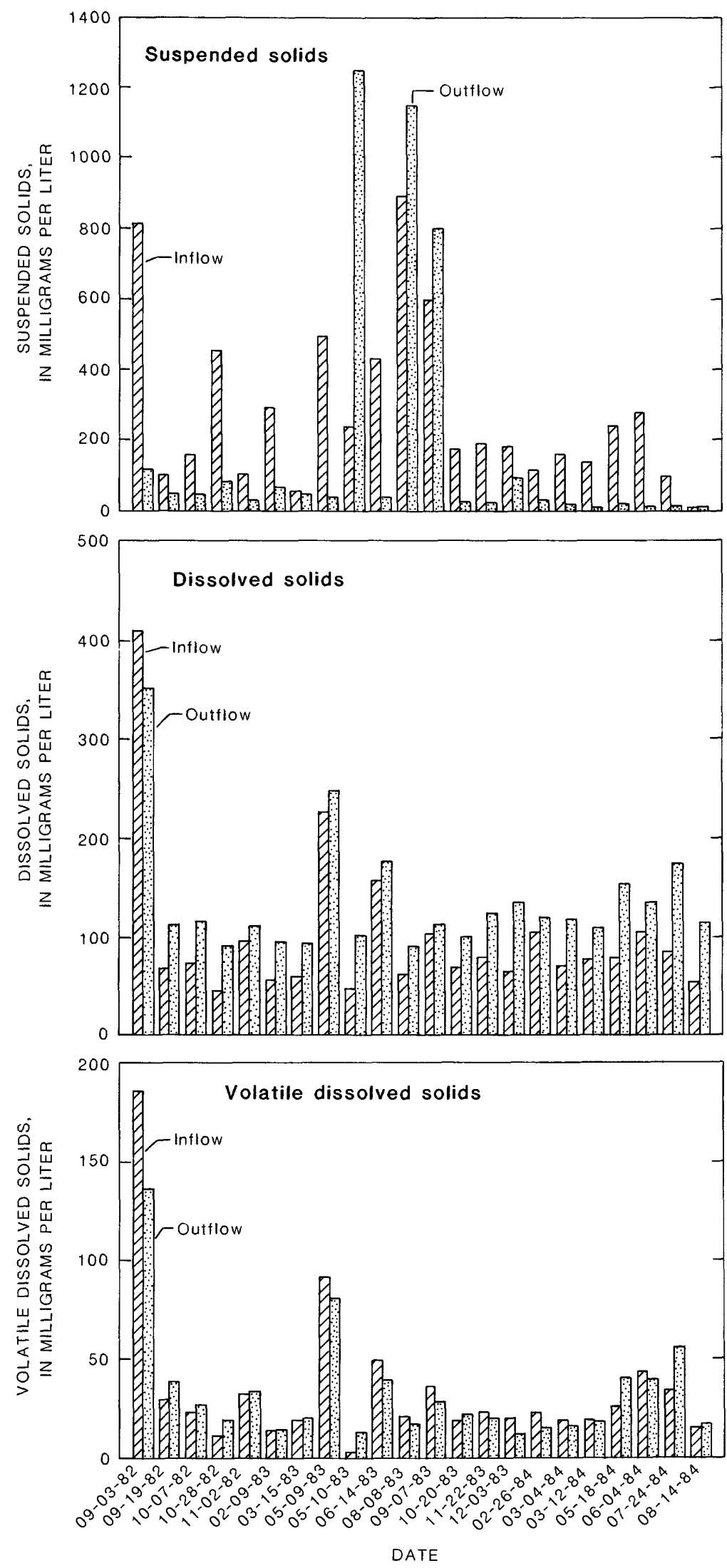

Figure 20.--Discharge-weighted concentrations of suspended solids, dissolved solids, and volatile dissolved solids in the inflow and outflow of Pond 1 at Barton Creek Square Shopping Center. 
inflow water to be in contact with the sand, silt, and clay in the pond and filter system.

The discharge-weighted average concentration of volatile dissolved solids ranged from 4 to $186 \mathrm{mg} / \mathrm{L}$ for the inflow and from 13 to $136 \mathrm{mg} / \mathrm{L}$ for the outflow station (fig. 20). For most storms, only small differences existed in dischargeweighted concentrations; for 11 of the 22 storms, discharge-weighted concentrations in the outflow exceeded those of the inflow.

Nitrogen

Discharge-weighted concentrations of total nitrogen ranged from 0.7 to 8.4 $\mathrm{mg} / \mathrm{L}$ as nitrogen for the inflow and from 0.8 to $9.2 \mathrm{mg} / \mathrm{L}$ as nitrogen for the outflow (fig. 21). In general, only small differences in discharge-weighted concentrations were noted between the inflow and outflow. Discharge-weighted concentrations of total nitrogen generally were slightly larger in the inflow, however, concentrations in the outflow exceeded those in the inflow on eight occasions. These data indicate that small amounts of nitrogen may be leached from previous deposition on the pond bed and filter, or that the determination of discharge-weighted concentrations of total nitrogen are relatively inaccurate. Inflow determinations may indeed be low because of the inability to accurately estimate the amount of nitrogen introduced into the pond from fertilizers applied adjacent to the pond. Figure 21 indicates that most of the nitrogen is being introduced into the pond as organic nitrogen and/or ammonia nitrogen. Discharge-weighted concentrations of total organic plus ammonia nitrogen were substantially larger in the inflow than concentrations of total nitrite plus nitrate nitrogen. Data in figure 21 al so indicate that discharge-weighted concentrations of total organic plus ammonia nitrogen are substantially larger in the inflow than in the outflow for most of the storms except for the May 10, 1983 storm in which pond outflow spilled over the outlet structure. Discharge-weighted concentrations of total organic plus ammonia nitrogen in the inflow ranged from 0.3 to $7.8 \mathrm{mg} / \mathrm{L}$ as nitrogen while corresponding concentrations in the outflow ranged from 0.3 to $3.7 \mathrm{mg} / \mathrm{L}$ as nitrogen. The highest concentrations of total organic plus ammonia nitrogen occurred during summer months between May and September, suggesting that some of the hitrogen in the pond probably was introduced from fertilizers.

Discharge-weighted concentrations of total nitrite plus nitrate nitrogen were substantially smaller in the inflow than in the outflow (fig. 21). The concentrations in the inflow ranged from 0.1 to $1.2 \mathrm{mg} / \mathrm{L}$ as nitrogen while concentrations in the outflow ranged from 0.2 to $5.5 \mathrm{mg} / \mathrm{L}$ as nitrogen. Concentrations in the outflow were larger apparently because much of the organic and ammonia nitrogen was being oxidized to nitrite and nitrate as water passes through the detention pond. It is also reasonable to assume that organic nitrogen trapped in the filter or deposited on the bed of the pond from previous storms is being oxidized to nitrate during dry periods and leached out during the next storm event.

\section{Phosphorus}

Discharge-weighted concentrations of total phosphorus in the inflow ranged from 0.09 to $0.58 \mathrm{mg} / \mathrm{L}$ as phosphorus (fig. 21). The largest concentrations 

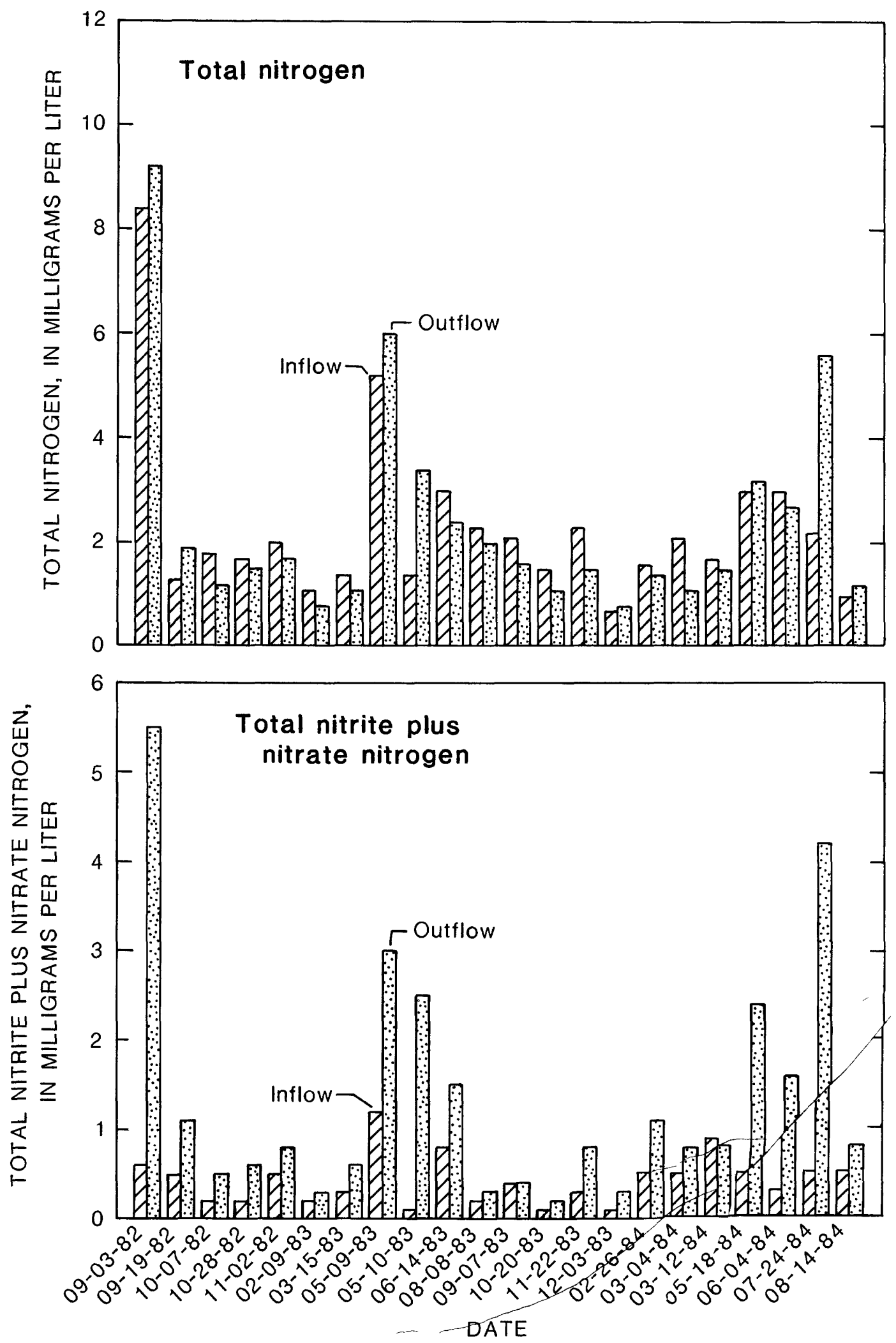

Figure 21.--Discharge-weighted concentrations of total nitrogen, total organic plus ammonia nitrogen, total nitrite plus ntrate nitrogen, and total phosphorus in the inflow and outflow of Pond 1 at Barton Creek Square Shopping Center. 

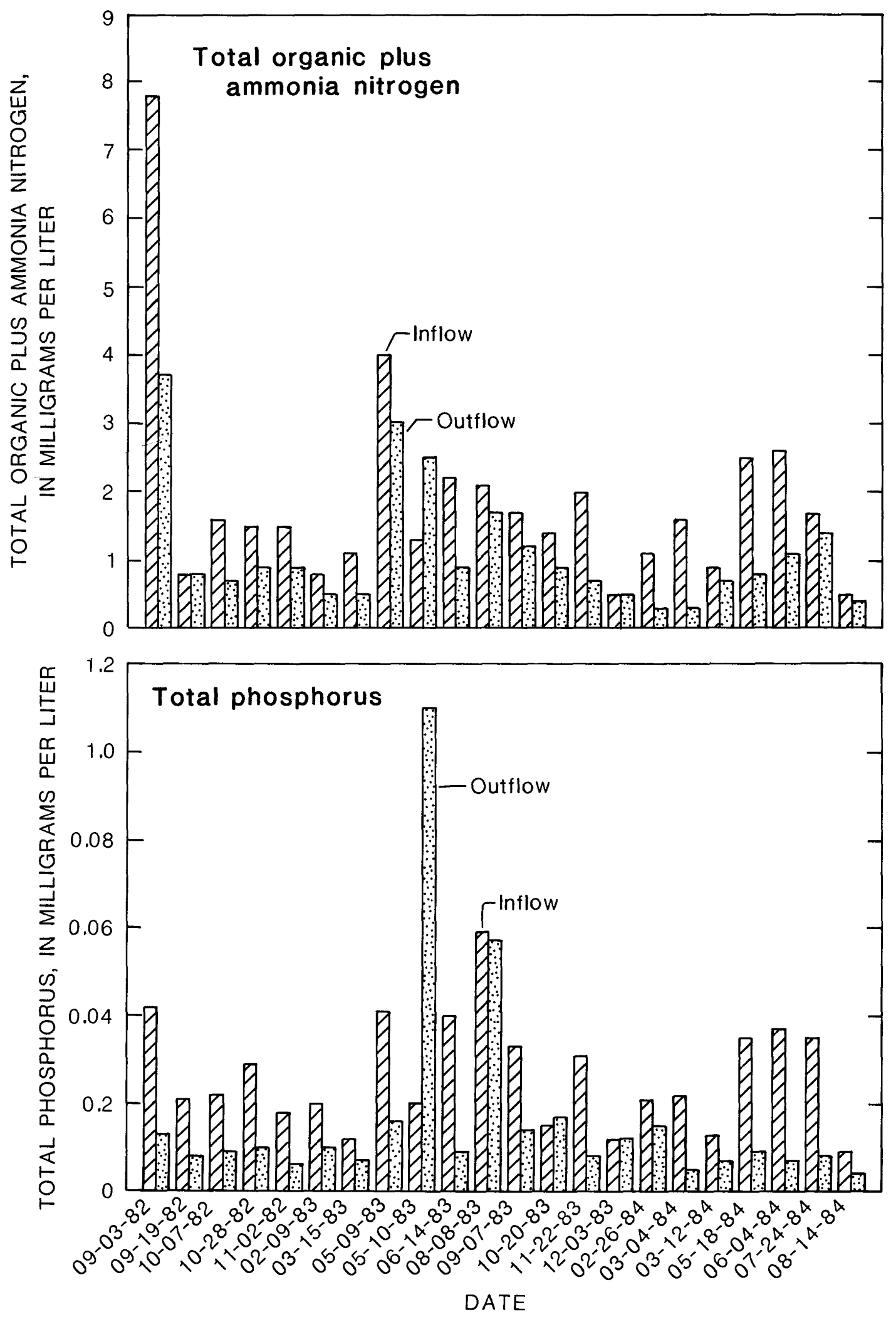

$-47-$ 
generally occurred during the warm summer months between May and September indicating that some of the phosphorus may have its origin as fertilizers. Concentrations in the outflow, which ranged from 0.04 to $1.1 \mathrm{mg} / \mathrm{L}$ as phosphorus, were substantially smaller than corresponding values in the inflow. Concentrations in the outflow exceeded that in the inflow only during the May 10-11, 1983, storm which overflowed the drop outlet. This indicates that a large amount of phosphorus entered the pond from the ungaged area during this storm. Total phosphorus concentrations from samples from the ungaged areas were as 1 arge as $2.0 \mathrm{mg} / \mathrm{L}$ as phosphorus (tables 4 and 5 ).

Dissolved trace elements

Discharge-weighted concentrations of trace metals were relatively small in both the inflow and outflow (fig. 22). Dissolved cadmium was less than the dection limits at the inflow site for every storm except for a value of $1 \mu \mathrm{g} / \mathrm{L}$ from one sample for the storm of Sept. 3, 1984. Discharge-weighted concentration of $1 \mathrm{\mu g} / \mathrm{L}$ was al so reported for the Feb. 9, $1983 \mathrm{storm}$ for the inflow, and for the Aug. 8-10, 1983 storm for the outflow. Discharge-weighted dissolvedlead concentrations did not exceed $10 \mu \mathrm{g} / \mathrm{L}$ (micrograms per liter) in either the inflow or outflow. The discharge-weighted concentrations ranged from less than $1 \mu \mathrm{g} / \mathrm{L}$ in both the inflow and outflow to $10 \mu \mathrm{g} / \mathrm{L}$ in the inflow and $9 \mu \mathrm{g} / \mathrm{L}$ in the outflow. Discharge-weighted dissolved-iron concentrations ranged from 10 to $350 \mu \mathrm{g} / \mathrm{L}$ in the inflow and from 9 to $90 \mu \mathrm{g} / \mathrm{L}$ in the outflow. The discharge-weighted concentrations in the inflow exceeded $100 \mu \mathrm{g} / \mathrm{L}$ on one occasion. Iron strongly adhers to suspended sediment, and it is probable that much of the iron was removed through sediment deposition in the pond or in the pond filter. Dischargeweighted concentrations of dissolved zinc ranged from 10 to $120 \mu \mathrm{g} / \mathrm{L}$ in the inflow and from 6 to $60 \mu \mathrm{g} / \mathrm{L}$ in the outflow. In general, the discharge-weighted concentrations of dissolved lead, dissolved iron, and dissolved zinc were larger in the inflow than in the outflow for most storms.

\section{Measured Peak Concentrations}

Discrete peak concentrations of most constituents in storm water generally occur just prior to peak discharges; however, depending on the nature of the storm, and the distance the chemical constituents must travel, peak concentrations may occur at or just following peak discharges. Peak concentrations in the outflow should be considerably less than peak concentrations in the inflow for most constituents because of dilution in the pond by less concentrated inflow, and by removal of constituents through sedimentation or filtration.

Four discrete water-quality samples were collected from six storms at both the inflow and outflow sites. The discrete water-quality samples collected at the inflow station represent flow only from the area in section A (fig. 2), whereas the discrete samples from the outflow represent total outflow which is composed of water from both the gaged and ungaged inflow areas. Only two of the six storms which had discrete samples analyzed, had runoff from the ungaged areas. The storm of November 2, 1982 , included 0.24 acre-ft from sections $C$ and $D$, and the storm of February 26, 1984, included 0.06 acre-ft from section $B$ and section $C$. Figures $9,10,11,12$, and 14 show where discrete water-quality samples were collected in relation to the inflow and outflow hydrographs. Figures 23-31 show the concentration or density of selected 

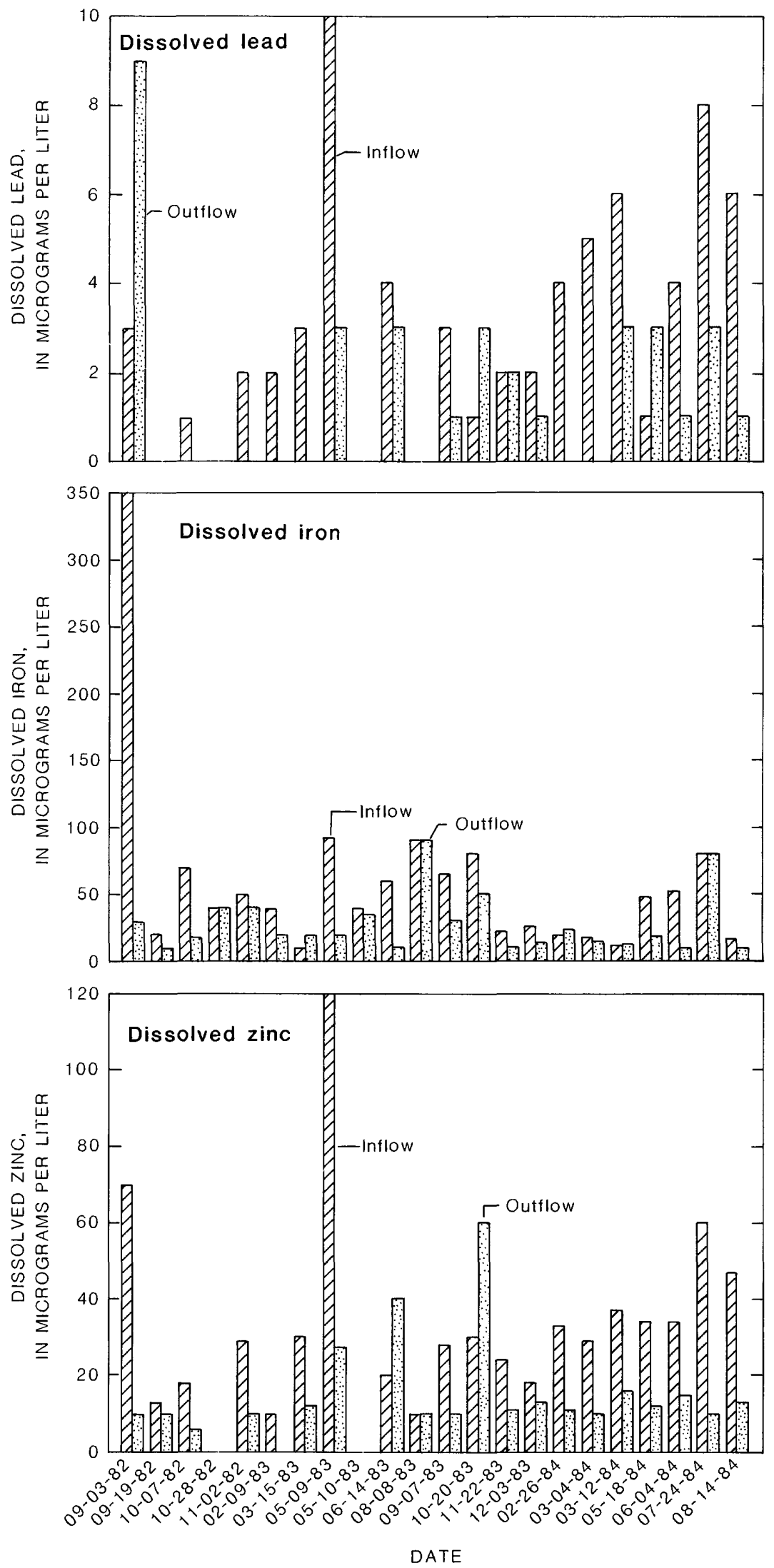

Figure 22.--Discharge-weighted concentrations of dissolved lead, dissolved iron, and dissolved zinc in the inflow and outflow of Pond 1 at Barton Creek Square Shopping Center. 

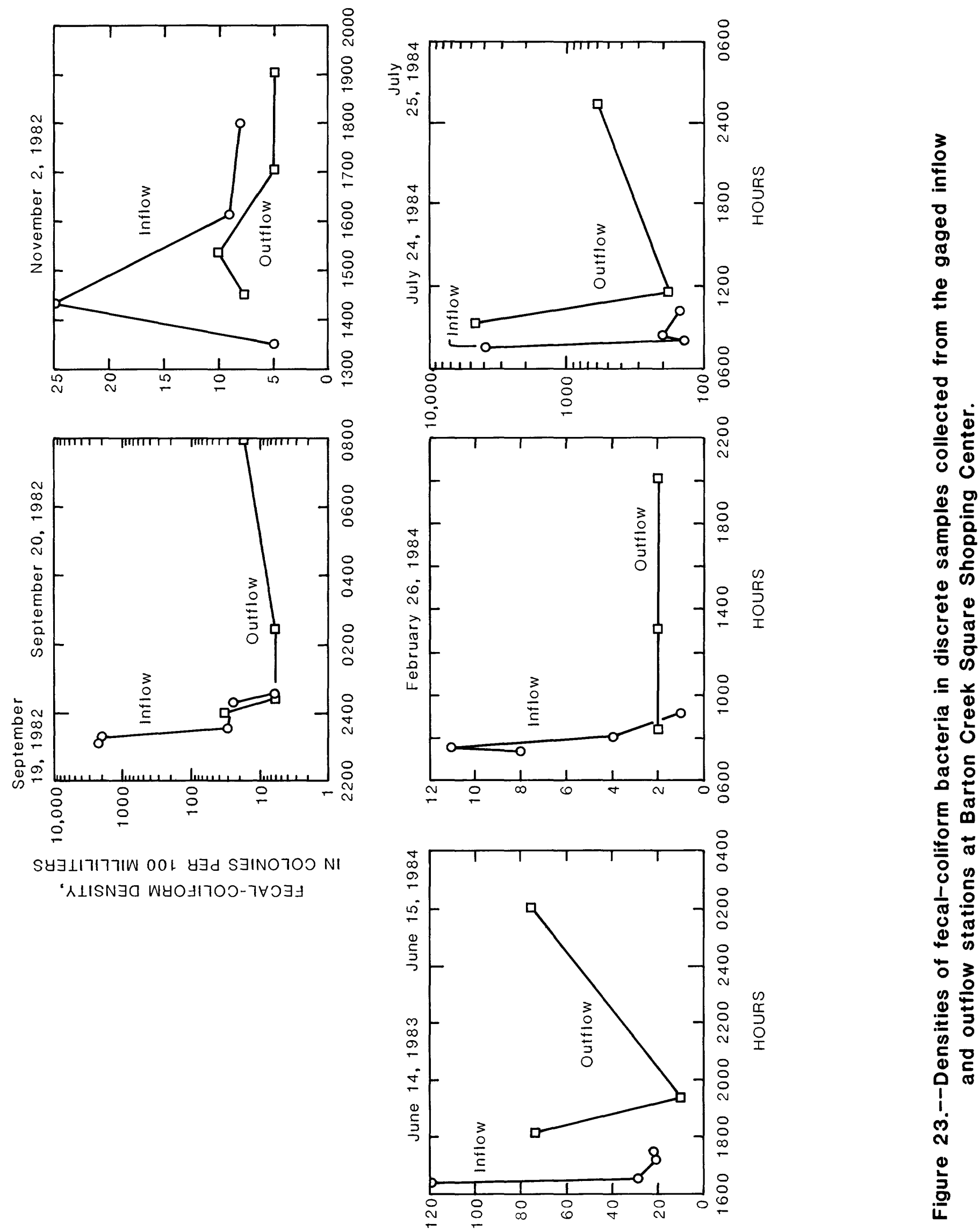

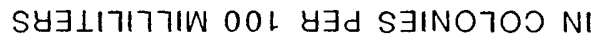

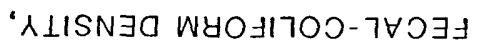



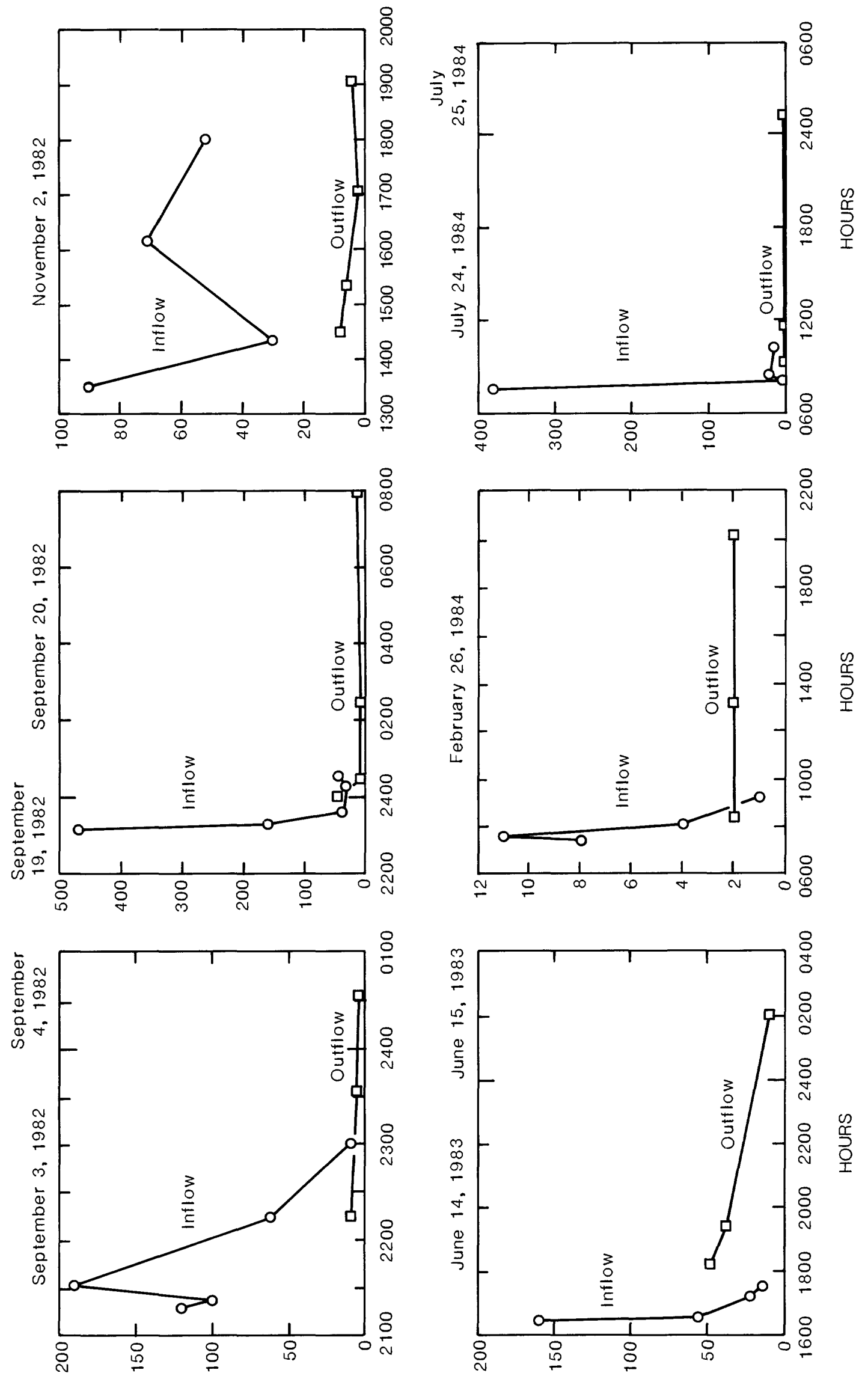

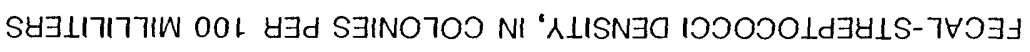



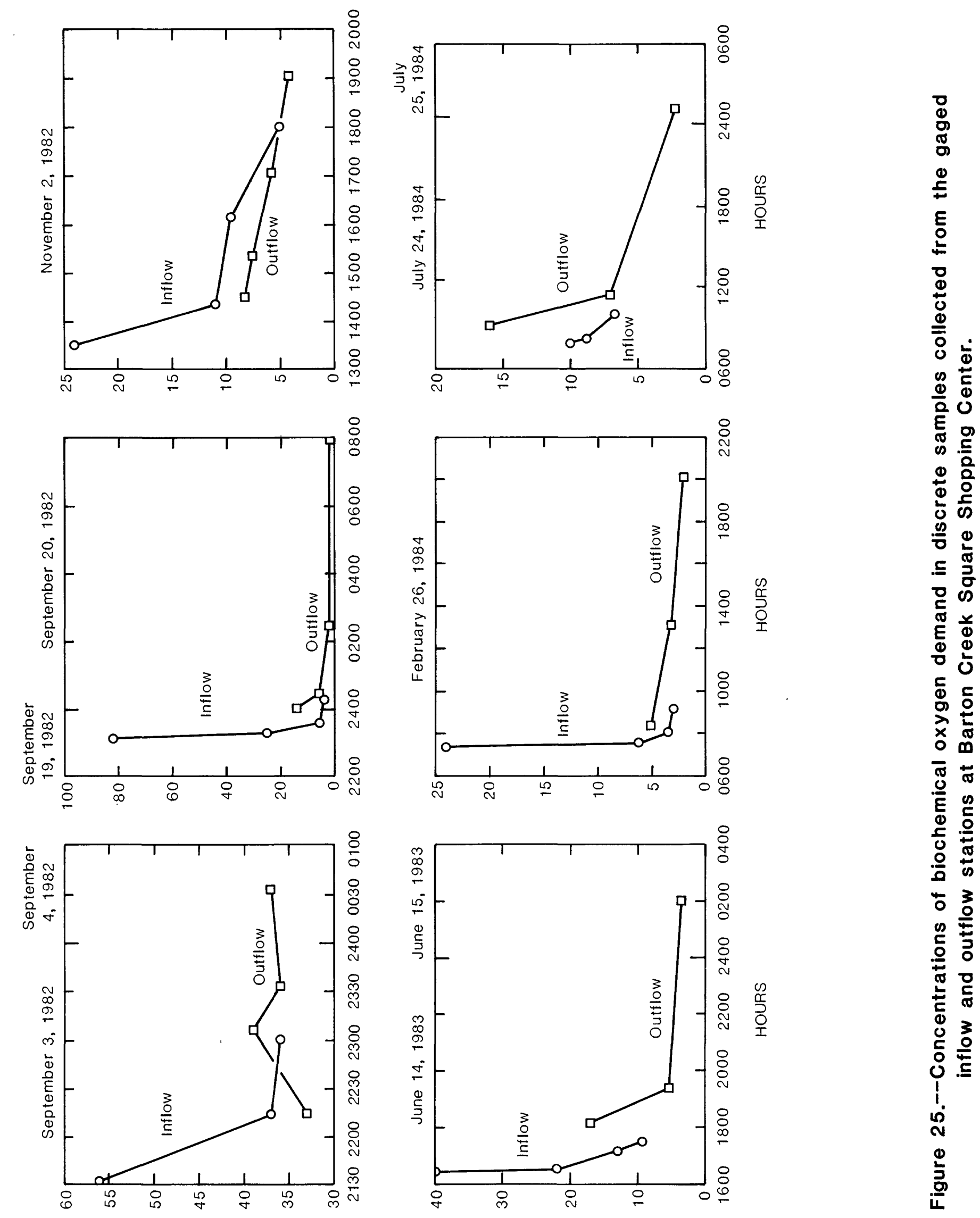

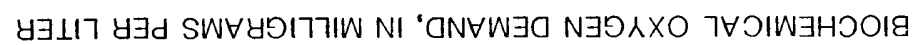



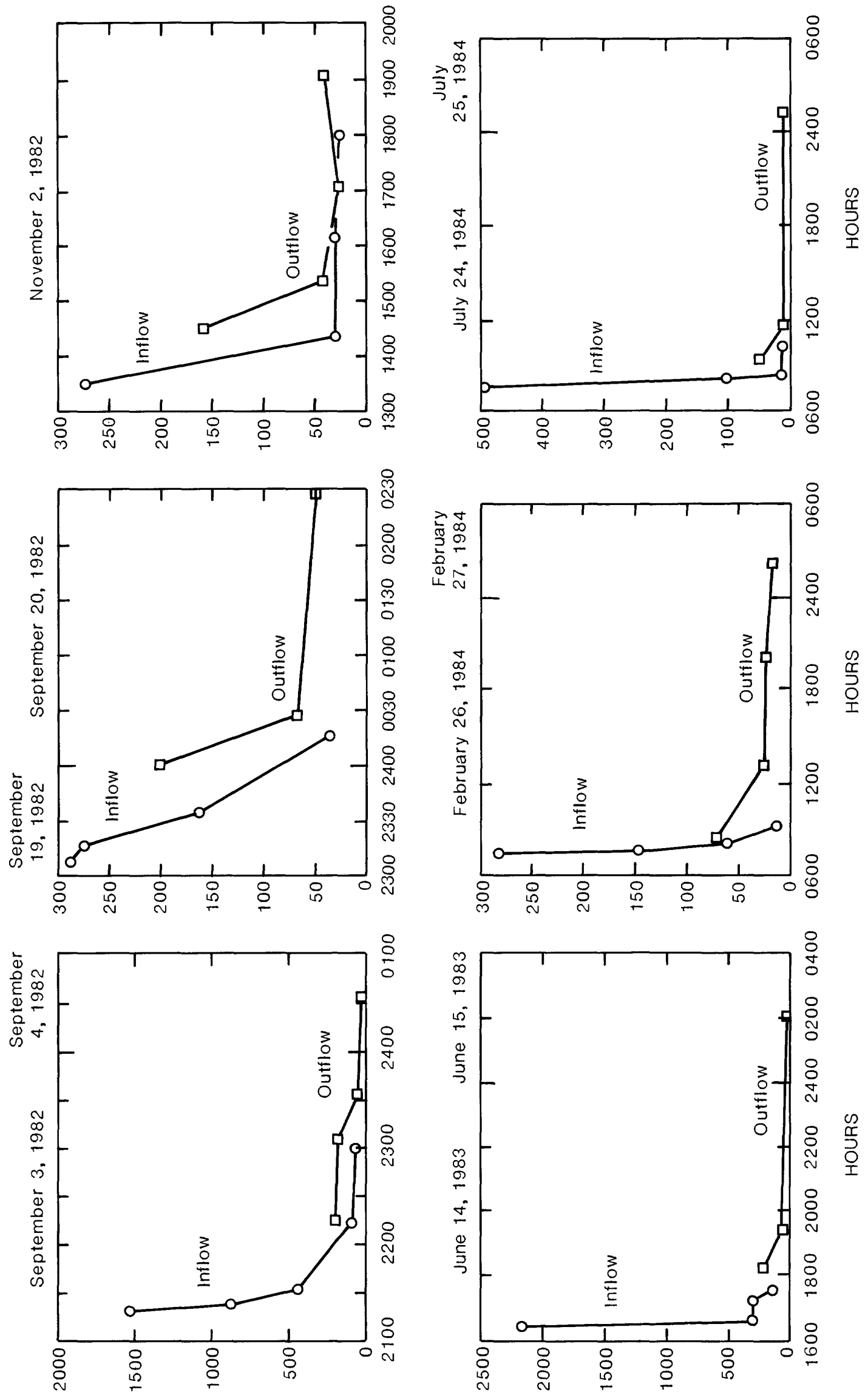

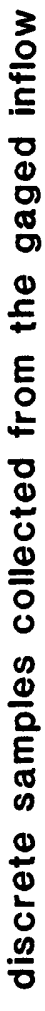

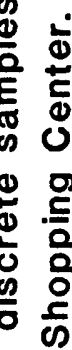



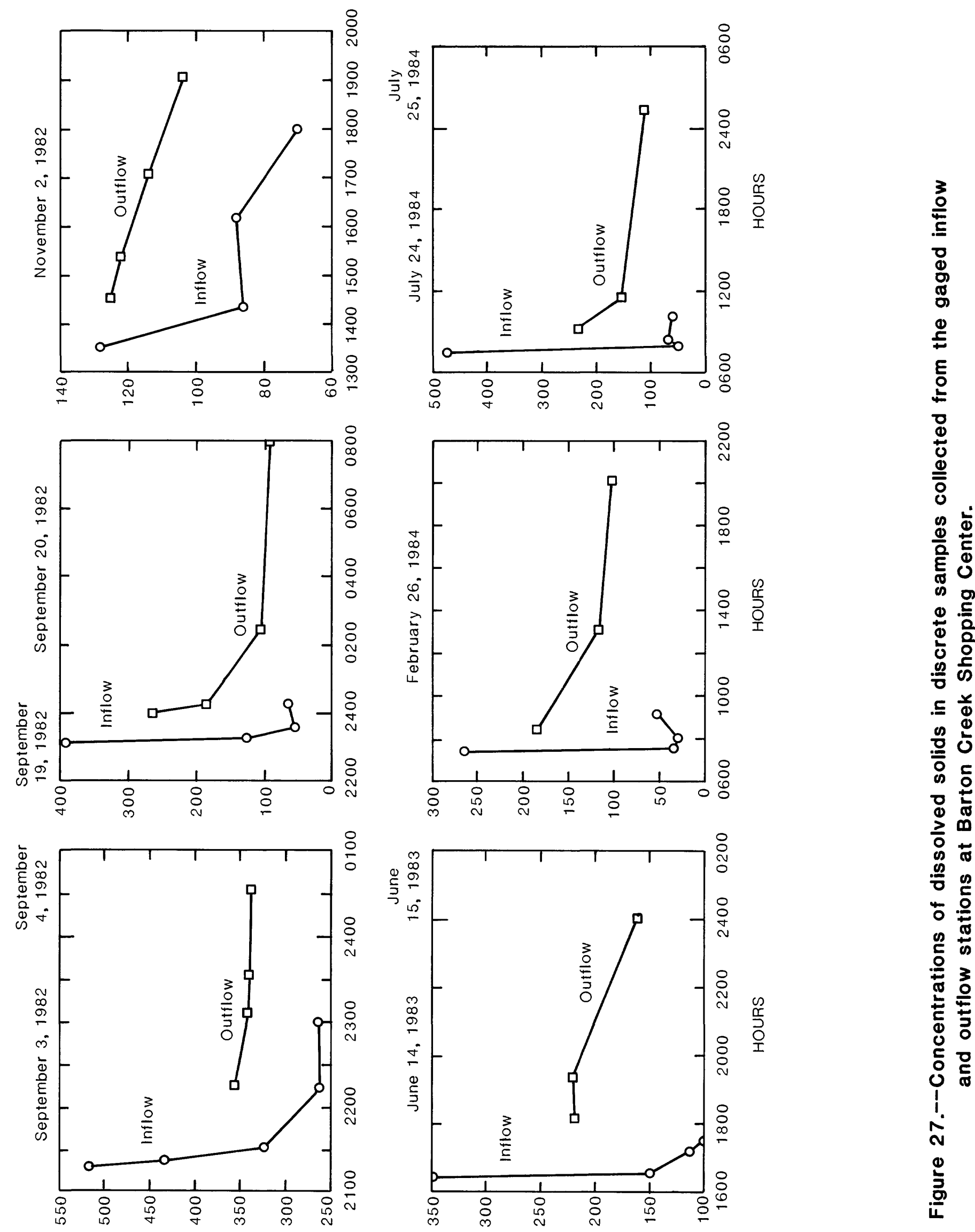

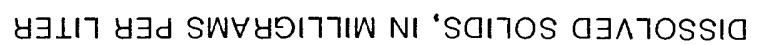



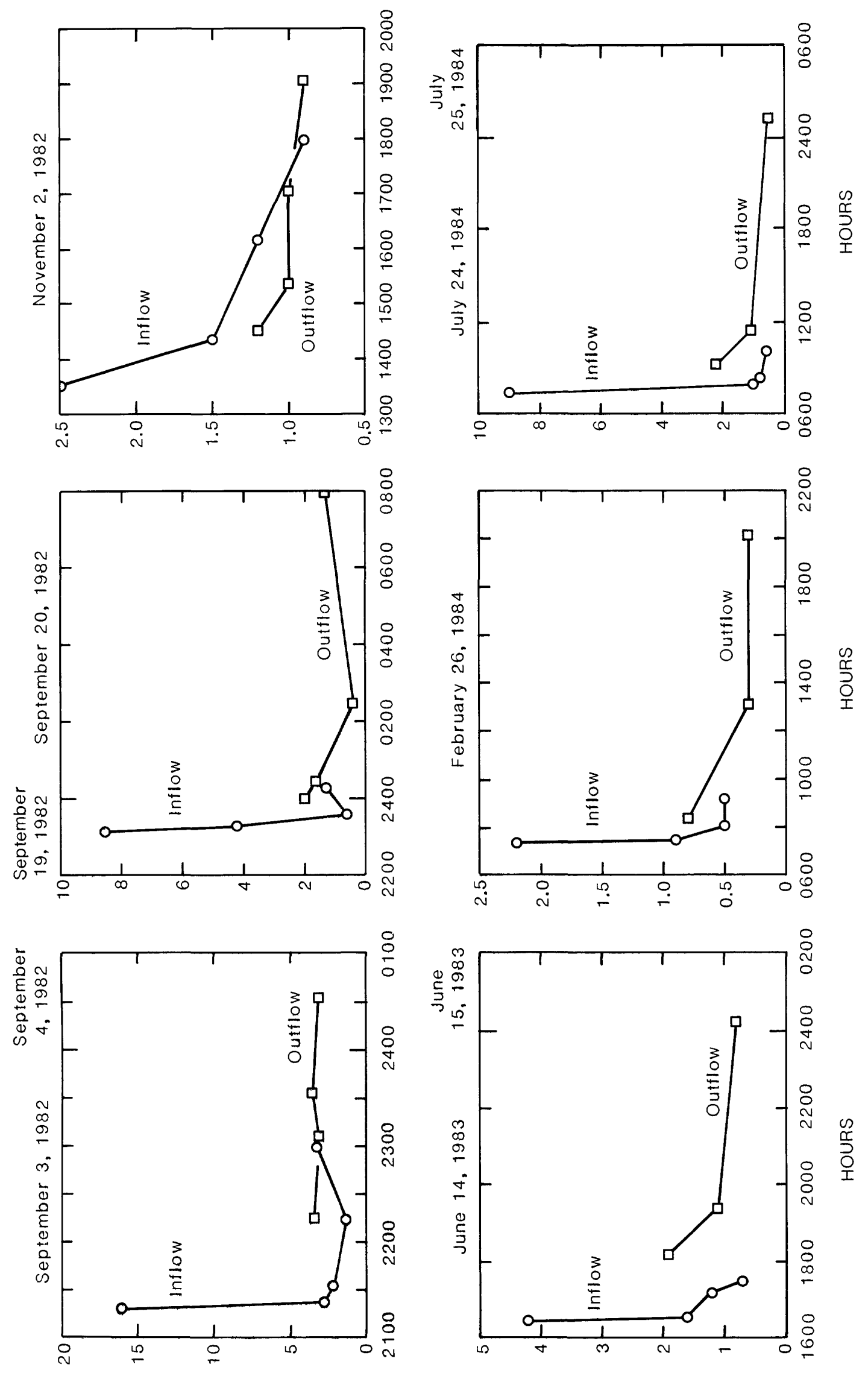

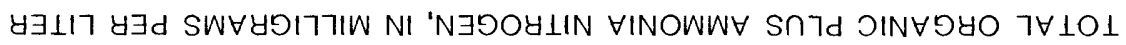



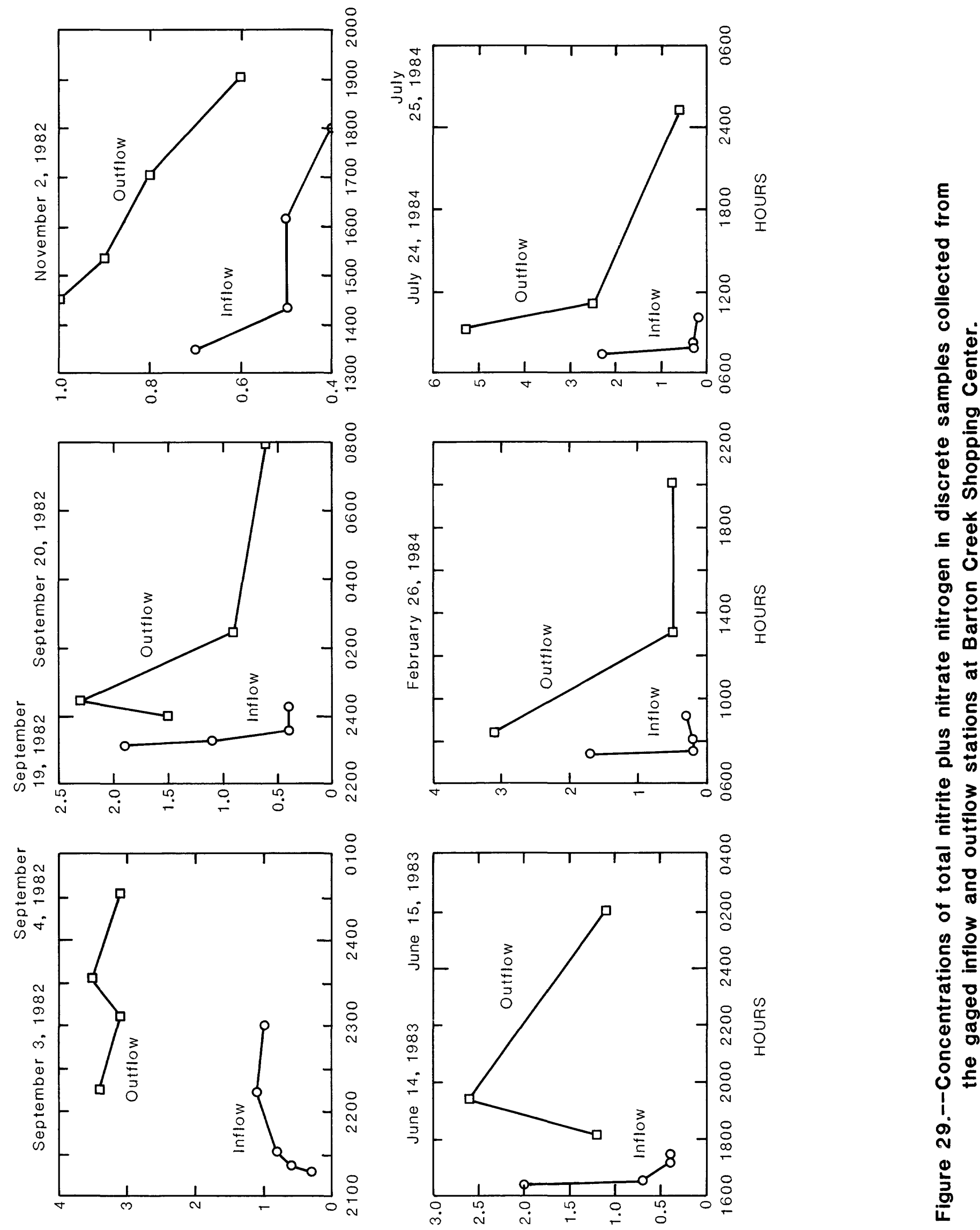

y $\exists \perp 17$ y 

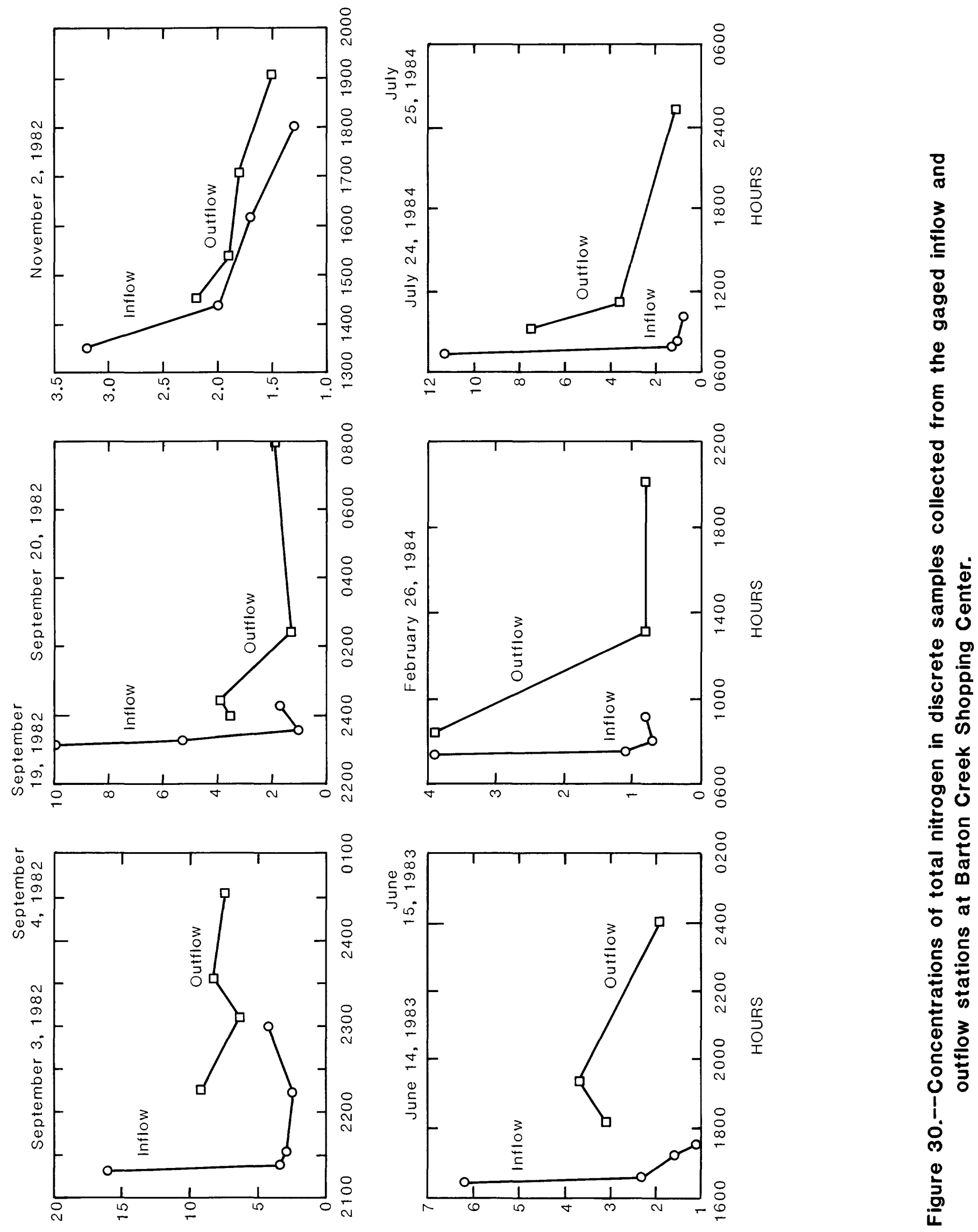

y $\exists 117$ y 

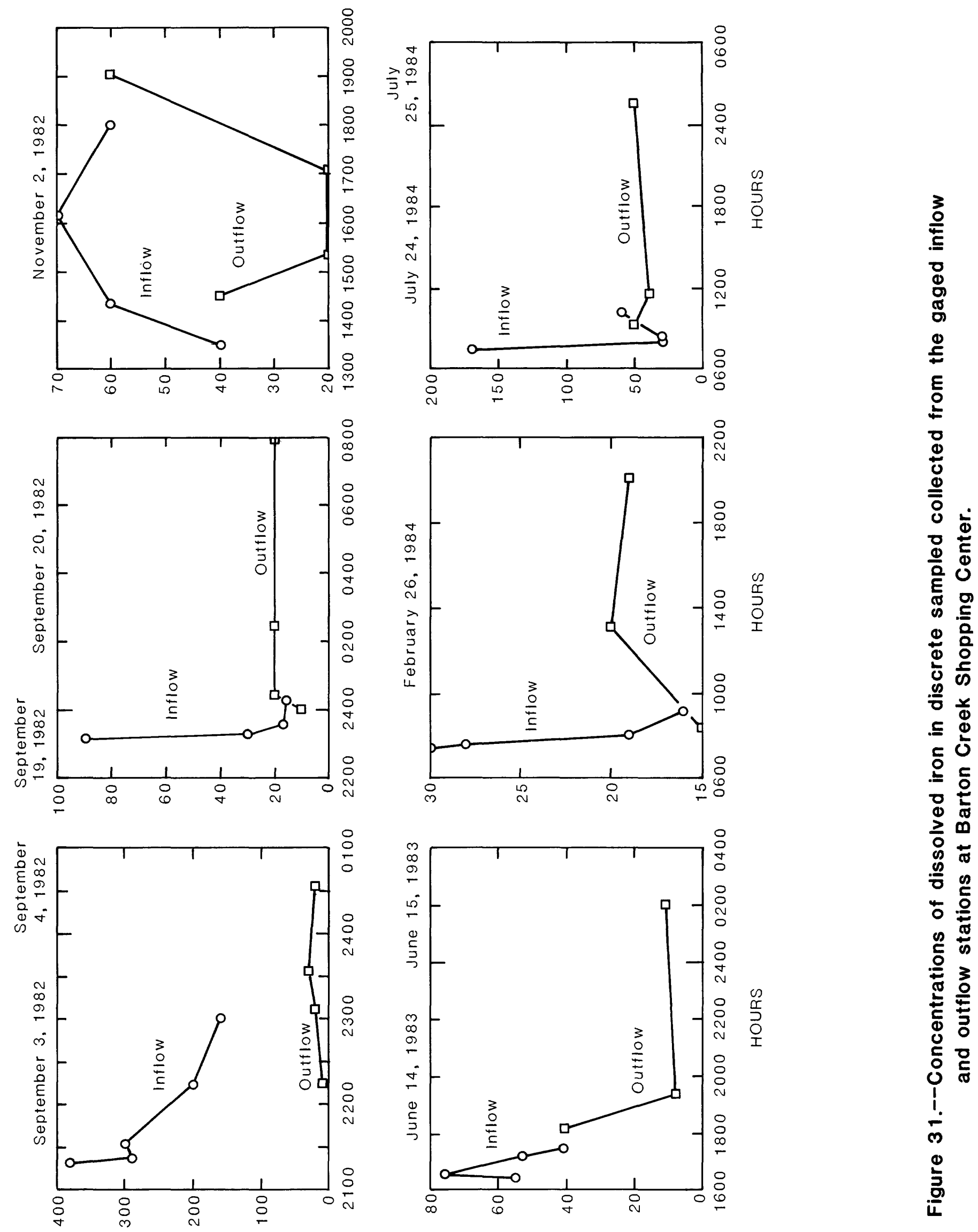

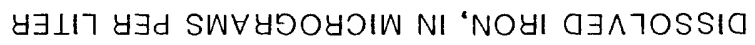


constituents for the inflow and outflow stations. It should be noted that the 1 argest concentrations or densities measured may not actually represent the 1 argest concentrations or densities. Often the largest concentration measured was in the first sample analyzed. The actual 1 argest or peak concentration could have occurred either before or after the 1 argest measured concentration.

In general, measured peak concentrations or densities of most constituents in the inflow were substantially larger than measured peak concentrations or densities in the outflow. An exception was noted for concentrations of total nitrite plus nitrate nitrogen (fig. 29). Measured peak concentrations of total nitrite plus nitrate nitrogen in the inflow were less than measured peak concentrations in the outflow for all six storms. Concentrations of total nitrite plus nitrate nitrogen are larger in the outflow because of oxidation of organic nitrogen and ammonia nitrogen to nitrite and subsequently to nitrate nitrogen.

Measured peak concentrations of dissolved solids (fig. 27) and total nitrogen (fig. 30) in the inflow were equal to or larger than concentrations in the outflow for all six storms; however, concentrations of these constituents in the outflow did not decrease as rapidly as other constituents. Dissolved solids are apparently being leached from the bed and filter of the pond causing a relatively slow increase in dissolved solids in the outflow. Concentrations of total nitrogen in the outflow varied considerably. During the storm of February 26, 1984, the measured peak concentration of total nitrogen in the inflow equaled that of the outflow. For the storms of September 3, 1982, and June 14, 1983, measured concentrations in the outflow were close to the minimum concentrations measured in the inflow. For the other four storms, the minimum total nitrogen concentrations in the inflow closely resembled minimum concentrations in the outflow. Concentrations of total nitrogen in the outflow may be dependent on the amount of organic nitrogen which has undergone decomposition when the pond and filter were dry. The breakdown of organic nitrogen during dry periods would make nitrate nitrogen available for leaching during subsequent storms.

Measured peak concentrations or densities of most constituents in the inflow generally occurred during the first or second discrete sample collected, which occurred about the same time as peak discharges. For those storms with secondary peaks in discharge, secondary increases were noted in bacteria densities and in dissolved-iron concentrations for some storms. For those storms where the measured peak concentrations occurred on the first discrete sample, it is possible the actual peak concentration could have been larger than that measured.

Loads

Loads of chemical constituents are a product of the constituent concentration and the discharge and represent the total weight of the constituent that passes a point in a specific time period. Loads may be computed from the following equation: 
where Loads = loads, in pounds per day,

$$
\text { Loads }=5.4 Q C
$$

$Q=$ discharge, in cubic feet per second,

$C=$ concentration, in milligrams per liter, and

5.4 = factor for converting the product of concentration, in milligrams per liter, and water discharge, in cubic feet per second, to pounds per day.

The total number of fecal-coliform and fecal-streptococci bacteria were determined by converting densities per 100 milliliters to densities per cubic foot and then multiplying by the total cubic feet of water flowing into and out of the detention pond.

Inflow loads of chemical constituents and total fecal-coliform and fecalstreptococci bacteria for each storm were computed by using discharge-weighted concentrations and gaged water discharge from section A (fig. 2). The loads and bacterial densities from sections $B, C$, and $D$ were estimated by using the results of periodic samples collected from sections $B$ and $D$ and the estimated runoff from the ungaged areas. The sum of the loads and bacterial densities from the four sections represent the total inflow load and total bacterial densities discharged to the pond. Loads and the total number of fecal-coliform and fecal-streptococci bacteria for the outflow were computed using the dischargeweighted concentrations of the outflow and the gaged discharge of the outflow.

One measure of the effectiveness of the runoff controls is the difference between total inflow and outflow loads. In this study, removal efficiencies are reported as the percentage of the total load or total number of bacteria that was removed by the pond. This was computed by dividing the difference between inflow loads and outflow loads by the total inflow load and multiplying by 100. Removal efficiencies were computed for each constituent for each storm. Average removal efficiencies for the study were computed as the arithmetic mean of the storm percentages. The removal efficiencies for the three storms which overflowed the drop outlet (May 10-11, August 8, and September $7-10,1983)$ were not included in the computation of the average removal efficiencies. These storms exceeded the design filtering capacity of the pond, and including these storms would bias the average removal efficiency.

The total number of fecal-coliform and fecal-streptococci bacteria and loads of most chemical constituents generally were decreased by the pond. Exceptions were noted for dissolved-solids loads and total nitrite plus nitrate nitrogen loads. Decreased loads in the outflow may be attributed partly to the loss of water to the unsaturated filter between the bottom of the pond and the perforated pipe, to unexplained losses as described earlier, and to the removal of bacteria and chemical constituents through the filter system. The 1 argest removal efficiencies were for bacteria (table 7), BOD (table 8), and suspended solids (table 9). The average removal efficiencies for fecal-coliform and fecal-streptococci bacteria were about 80 percent and the average removal efficiencies of suspended solids and BOD were about 75 percent. The average 1oads of TOC (table 8), COD (table 8), and dissolved zinc (table 11) were reduced by about 60 percent. Removal efficiencies for total ammonia plus organic nitrogen (table 10) and dissolved iron (table 11) were approximately 55 percent, whereas removal efficiencies for total nitrogen (table 10), dissolved lead (table 11), and dissolved volatile solids (table 9) were between 21 and 33 percent. 
Table 7.--Densities of fecal-coliform and fecal-streptococci bacteria and removal efficiencies at Barton Creek Square Shopping Center

[Runoff 1, from shopping mal1; 2, from shopping mall and intervening areas; 3, includes flow through drop outlet]

\begin{tabular}{|c|c|c|c|c|c|c|c|}
\hline \multirow{2}{*}{$\begin{array}{l}\text { Run- } \\
\text { off }\end{array}$} & $\begin{array}{c}\text { Date of } \\
\text { storm }\end{array}$ & \multicolumn{3}{|c|}{ Fecal coliform bacteria } & \multicolumn{3}{|c|}{ Fecal-streptococci bacteria } \\
\hline & 1982 & & & & & & \\
\hline 1 & Sept. 3 & -- & - & $\cdots$ & 540 & 9.8 & 98.2 \\
\hline 1 & Sept. $19-20$ & 14,000 & 270 & 98.1 & 1,600 & 600 & 62.5 \\
\hline 2 & oct. 28 & 290 & 45 & 84.5 & 630 & 68 & 89.2 \\
\hline \multirow[t]{2}{*}{2} & Nov. 2 & 2,000 & 160 & 92.0 & 2,800 & 300 & 89.3 \\
\hline & $\underline{1983}$ & & & & & & \\
\hline 2 & Feb. 9 & 1,050 & 91 & 91.3 & 440 & 51 & 88.4 \\
\hline 3 & May 10-11 & 2,900 & 1,300 & 55.2 & 4,300 & 2,700 & 37.2 \\
\hline 1 & June 14 & 1,200 & 670 & 44.2 & 710 & 300 & 57.7 \\
\hline 3 & Aug. 8 & 7,900 & 4,500 & 43.0 & 17,000 & 7,900 & 53.5 \\
\hline 3 & Sept. 7-10 & 8,000 & 1,800 & 77.5 & 4,800 & 740 & 84.5 \\
\hline 1 & oct. 20 & 3,100 & 1,700 & 45.2 & 3,000 & 1,400 & 53.3 \\
\hline 1 & Nov. $22-23$ & 200 & 49 & 75.5 & 150 & 160 & 6.7 \\
\hline 2 & Dec. 3 & 1,200 & 490 & 59.1 & 520 & 210 & 59.6 \\
\hline 1 & May 18 & 700 & 110 & 84.3 & 2,000 & 120 & 94.0 \\
\hline 2 & June $\quad 4-5$ & 31,000 & 1,800 & 94.2 & 1,300 & 38 & 97.1 \\
\hline 1 & July 24 & 53,000 & 12,000 & 77.4 & 1,200 & 28 & 97.7 \\
\hline 1 & Aug. 14 & 41,000 & 1,500 & 96.6 & 820 & 41 & 95.0 \\
\hline \multicolumn{2}{|c|}{ Average of 1 and 2} & -- & -- & 80.7 & -- & -- & 80.5 \\
\hline
\end{tabular}


Table 8.--Loads for biochemical oxygen demand, chemical oxygen demand, and total organic carbon and removal efficiencies at Barton Creek Square Shopping Center

[Runoff 1, from shopping mal1; 2, from shopping mall and intervening areas; 3, includes flow through drop outlet]

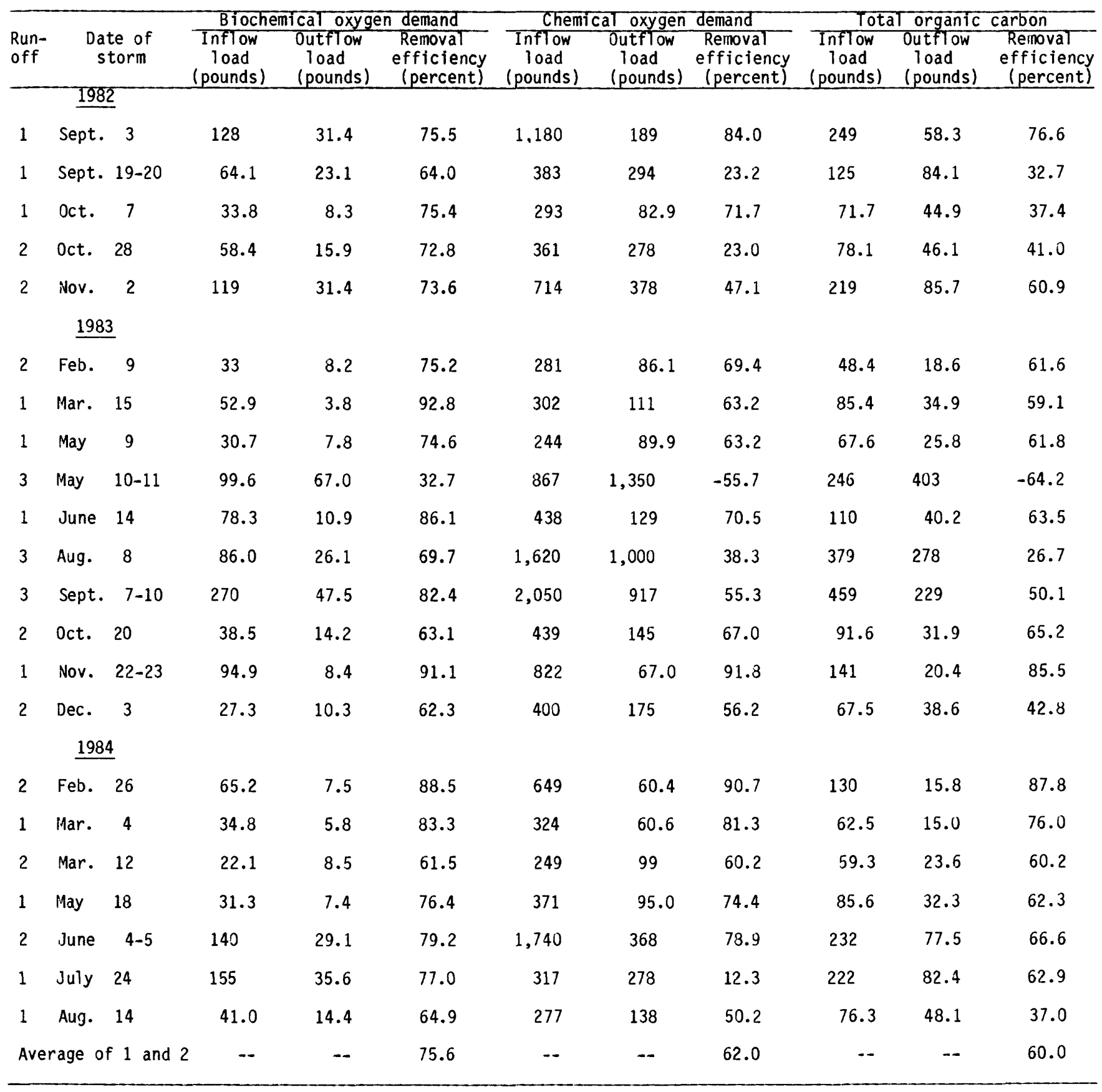


Table 9.--Loads for suspended solids, dissolved solids, and dissolved volatile solids and removal efficiencies at Barton Creek Square Shopping Center

[Runoff 1, from shopping mal1; 2, from shopping mall and intervening areas; 3, includes flow through drop outlet]

\begin{tabular}{|c|c|c|c|c|c|c|c|c|c|c|}
\hline \multirow{2}{*}{$\begin{array}{l}\text { Run- } \\
\text { off }\end{array}$} & \multirow[b]{2}{*}{$\begin{array}{c}\text { Date of } \\
\text { storm }\end{array}$} & \multicolumn{3}{|c|}{ Suspended solids } & \multicolumn{3}{|c|}{ Dissolved sotids } & \multicolumn{3}{|c|}{ Dissolved volatile solids } \\
\hline & & $\begin{array}{c}\text { Inflow } \\
\text { load } \\
\text { (pounds) }\end{array}$ & $\begin{array}{l}\text { Outflow } \\
\text { load } \\
\text { (pounds) }\end{array}$ & $\begin{array}{l}\text { Removal } \\
\text { efficiency } \\
\text { (percent) }\end{array}$ & $\begin{array}{c}\text { Inftow } \\
\text { load } \\
\text { (pounds) }\end{array}$ & $\begin{array}{l}\text { Outflow } \\
\text { load } \\
\text { (pounds) }\end{array}$ & $\begin{array}{l}\text { Removal } \\
\text { efficiency } \\
\text { (percent) }\end{array}$ & $\begin{array}{c}\text { Inftow } \\
\text { load } \\
\text { (pounds) }\end{array}$ & $\begin{array}{l}\text { Outflow } \\
\text { load } \\
\text { (pounds) }\end{array}$ & $\begin{array}{l}\text { Removal } \\
\text { efficiency } \\
\text { (percent) }\end{array}$ \\
\hline \multicolumn{11}{|c|}{1982} \\
\hline 1 & Sept. 3 & 1,270 & 105 & 91.7 & 639 & 316 & 50.5 & 290 & 122 & 57.9 \\
\hline 1 & Sept. $19-20$ & 805 & 350 & 56.5 & 540 & 792 & -46.7 & 235 & 273 & -16.2 \\
\hline 1 & Dct. 7 & 547 & 158 & 71.1 & 252 & 404 & -60.3 & 81.9 & 93.4 & -14.0 \\
\hline 2 & Oct. 28 & 2,800 & 417 & 85.1 & 287 & 456 & -58.8 & 71.7 & 99.0 & -38.1 \\
\hline \multirow[t]{2}{*}{2} & Nov. 2 & 1,030 & 228 & 77.9 & 942 & 799 & 15.2 & 322 & 243 & 24.5 \\
\hline & $\underline{1983}$ & & & & & & & & & \\
\hline 2 & Feb. 9 & 2,050 & 308 & 85.0 & 403 & 435 & -7.9 & 107 & 68.0 & 36.4 \\
\hline 1 & Mar. 15 & 302 & 168 & 44.4 & 347 & 328 & 5.5 & 114 & 73.3 & 35.7 \\
\hline 1 & May 9 & 390 & 24 & 93.8 & 180 & 149 & 17.2 & 72.4 & 48.5 & 33.0 \\
\hline 3 & May $10-11$ & 20,800 & 20,700 & .5 & 2,190 & 2,330 & -6.4 & 226 & 322 & -42.5 \\
\hline 1 & June 14 & 1,360 & 115 & 91.5 & 495 & 512 & -3.4 & 157 & 115 & 26.8 \\
\hline 3 & Aug. 8 & 22,900 & 21,400 & 6.6 & 1,580 & 1,710 & -8.2 & 545 & 335 & 38.5 \\
\hline 3 & Sept. $7-10$ & 13,200 & 13,100 & .8 & 2,310 & 1,870 & 19.0 & 822 & 475 & 42.2 \\
\hline 2 & 0ct. 20 & 1,330 & 81.1 & 93.9 & 530 & 293 & 44.7 & 154 & 66.7 & 56.7 \\
\hline 1 & Nov. $22-23$ & 1,220 & 75.7 & 93.8 & 512 & 364 & 28.9 & 152 & 61.1 & 59.8 \\
\hline \multirow[t]{2}{*}{2} & Dec. 3 & 1,350 & 568 & 57.9 & 478 & 821 & -71.8 & 81.7 & 78.5 & 3.9 \\
\hline & $\underline{1984}$ & & & & & & & & & \\
\hline 2 & Feb. 26 & 737 & 94.9 & 87.1 & 629 & 348 & 44.5 & 142 & 46.0 & 67.6 \\
\hline 1 & Mar. 4 & 625 & 57.8 & 90.7 & 281 & 344 & -22.4 & 78.2 & 49.1 & 37.2 \\
\hline 2 & Mar. 12 & 699 & 47.1 & 93.3 & 398 & 523 & -31.4 & 101 & 89.2 & 11.7 \\
\hline 1 & May 18 & 693 & 39.9 & 94.2 & 228 & 294 & -28.9 & 77.0 & 77.9 & -1.2 \\
\hline 2 & June $\quad 4-5$ & 2,360 & 71.1 & 97.0 & 892 & 378 & 1.6 & 364 & 258 & 29.1 \\
\hline 1 & July 24 & 738 & 65.1 & 91.2 & 635 & 759 & -19.5 & 253 & 243 & 5.8 \\
\hline 1 & Aug. 14 & 76.3 & 82.4 & -8.0 & 388 & 789 & -103 & 111 & 124 & -11.7 \\
\hline \multicolumn{2}{|c|}{ Average of 1 and 2} & - & -- & 78.3 & - & - & -12.9 & -- & -- & 21.3 \\
\hline
\end{tabular}


Table 10.--Loads for nitrite plus nitrate nitrogen, organic plus ammonia nitrogen, and total nitrogen and removal efficiencies at Barton Creek Square Shopping Center

[Runoff 1, from shopping mal1; 2, from shopping mall and intervening areas; 3, includes flow through drop outlet]

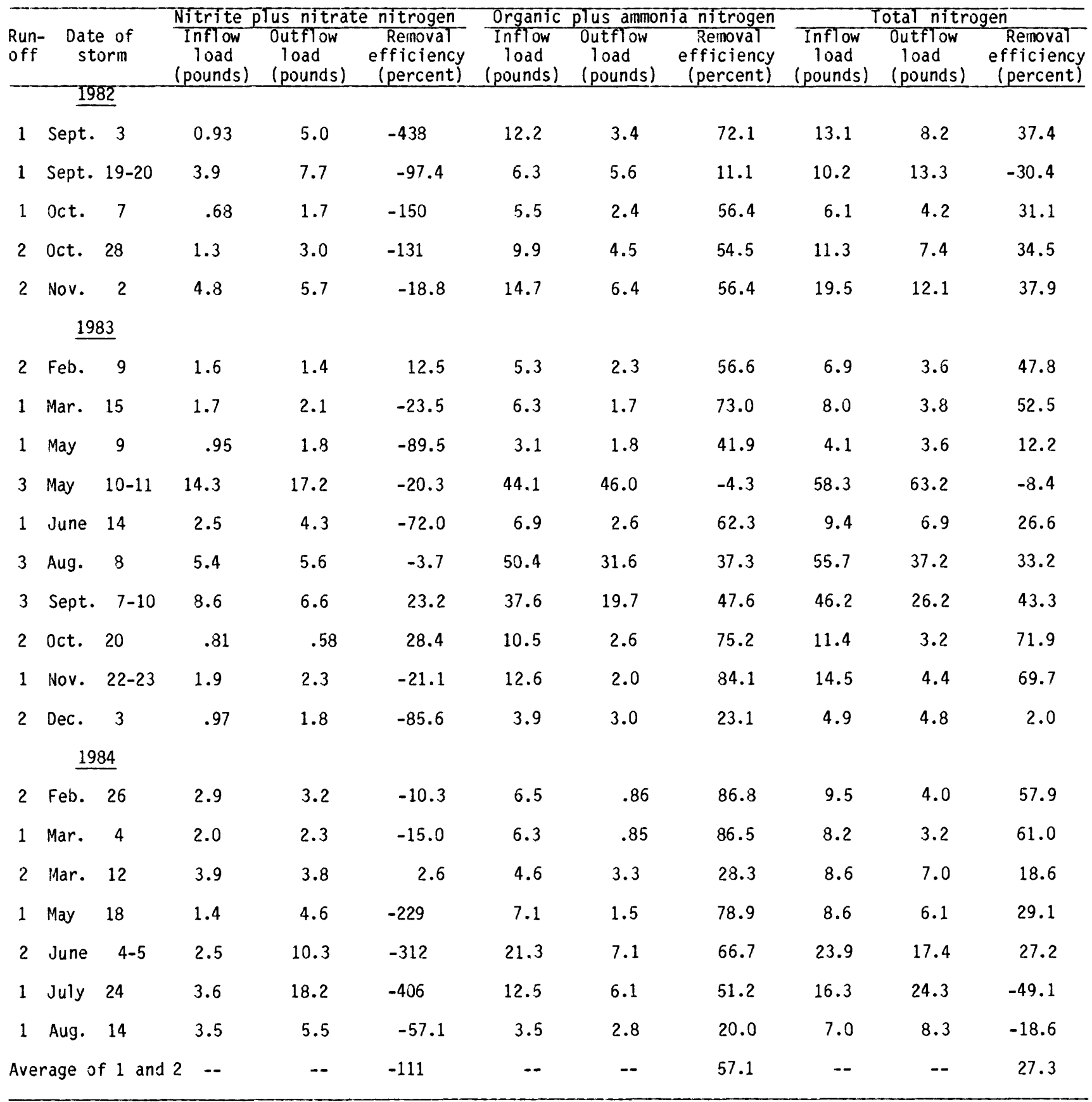


Table 11.--Loads for dissolved lead, dissolved iron, and dissolved zinc and removal efficiencies at Barton Creek Square Shopping Center

[Runoff 1, from shopping mal1; 2, from shopping mall and intervening areas; 3, includes flow tinrough drop outlet]

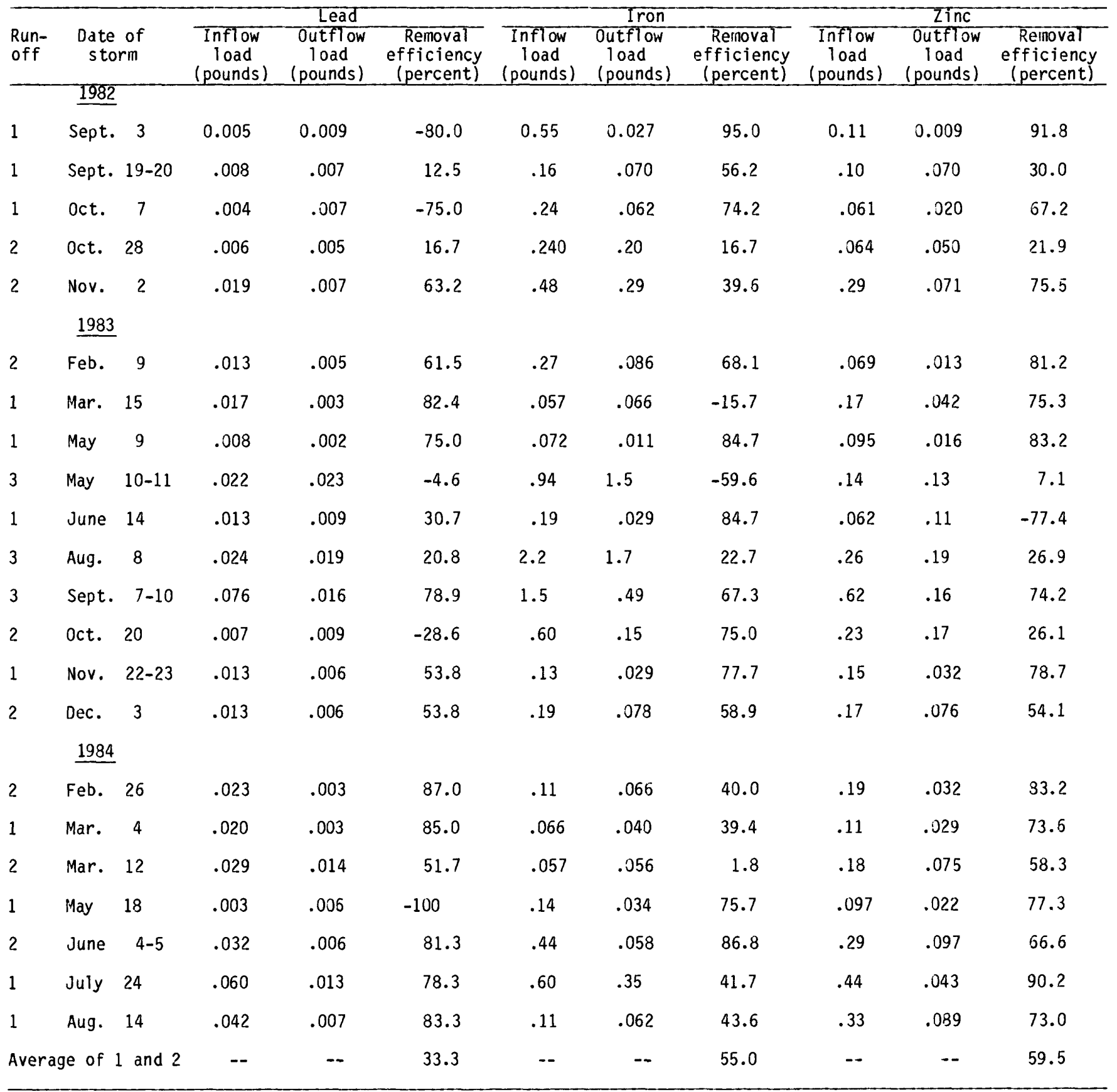


Average dissolved-solids loads were approximately 13 percent 1 arger in the outflow than the inflow (table 9). This is possibly due to the mineralization of organic matter deposited on the filter and dissolution of evaporites and dust from the sand bed and filter system. Loads of total nitrite plus nitrate nitrogen in the outflow were approximately 110 percent 1 arger than loads measured in the inflow (table 10). The oxidation of organic nitrogen and ammonia nitrogen to nitrite and nitrate nitrogen decreased loads of total organic plus ammonia nitrogen and increased loads of total nitrite plus nitrate nitrogen as water passed through the pond.

\section{EFFECTS OF RUNOFF CONTROLS AT ALTA VISTA}

The original study approach was developed on the premise that the influo ence of the runoff controls at this site could be determined by the difference in data between the inflow and outflow stations. However, field observations and analyses of the data during the course of the study showed that this approach would not provide data of sufficient accuracy to meet the study's objective. Some of the difficulties encountered include:

(1) The instrumentation to measure the outflow was located in the drop inlet structure. The turbulence of the water and the insensitive stage-discharge relation precluded the computation of accurate outflow discharge.

(2) Flow from the ungaged drainage area (west channel, fig. 8) yielded a significant quantity of runoff that was not measured before it passed through the detention area.

(3) A varying amount of runoff from the ungaged tributary overflowed the drainage boundaries for some storms.

As a result of these difficulties, a quantitative hydrologic analysis of the effects of the runoff controls could not be made.

\section{Rainfall-Runoff Characteristics}

For the Alta Vista area, 19 storms sampled for water quality were analyzed for rainfall and runoff characteristics. These characteristics included maximum rainfall intensities, total rainfall, runoff, and instantaneous peak discharges. A summary of rainfall and inflow characteristics is presented in table 12.

Total rainfall for the selected storms ranged from 0.25 to $2.00 \mathrm{in}$. For all of the storms, maximum rainfall for 5-, 10-, and 15-minute intervals was below the 2-year return interval as determined by Carter (1975).

Peak discharges for the inflow station are presented in table 12 for the 19 selected storms. At the inflow station, the peak discharge occurred an average of 10 minutes after the end of the maximum 5-minute rainfall. The travel time of the flood wave between the inflow and outflow stations is very short. Consequently, the peak discharge at the outfiow station al so occurred an average of 10 minutes after the maximum 5-minute rainfall. At both stations, the time of concentration varied from storm to storm, and for some storms the peak discharge occurred at the outflow station earlier than the inflow station. Five- 
Table 12.--Rainfall-runoff characteristics of selected storms at Alta Vista $\left[\mathrm{ft}^{3} / \mathrm{s}\right.$, cubic foot per second]

\begin{tabular}{|c|c|c|c|c|c|c|c|c|}
\hline Begin- & & & Sainfall & & & & Inflow & \\
\hline $\begin{array}{l}\text { ning } \\
\text { date of } \\
\text { storm }\end{array}$ & $\begin{array}{l}\text { Duration } \\
\text { (hours) }\end{array}$ & $\begin{array}{c}\text { Maximum } \\
5- \\
\text { minute } \\
\text { (inches) }\end{array}$ & $\begin{array}{c}\text { Maximum } \\
10- \\
\text { minute } \\
\text { (inches) }\end{array}$ & $\begin{array}{c}\text { Maximum } \\
15- \\
\text { minute } \\
\text { (inches) }\end{array}$ & $\begin{array}{l}\text { Total } \\
\text { (inches) }\end{array}$ & $\begin{array}{l}\text { Runoff } \\
\text { (inches) }\end{array}$ & $\begin{array}{l}\text { Ratio of } \\
\text { runoff to } \\
\text { rainfall }\end{array}$ & $\begin{array}{l}\text { Peak } \\
\text { dis- } \\
\text { charge } \\
\left(\mathrm{ft}^{3} / \mathrm{s}\right)\end{array}$ \\
\hline $09 / 19 / 82$ & 2.08 & 0.16 & 0.28 & 0.38 & 1.35 & 0.43 & 0.32 & 0.67 \\
\hline $11 / 02 / 82$ & 8.25 & .20 & .28 & .30 & 2.00 & .74 & .37 & .43 \\
\hline $03 / 15 / 83$ & 2.50 & .04 & .07 & .10 & .50 & .35 & .70 & .08 \\
\hline $03 / 30 / 83$ & 1.00 & .11 & .22 & .33 & .40 & .17 & .42 & .08 \\
\hline $05 / 10 / 83$ & 7.75 & .30 & .50 & .65 & 1.90 & .93 & .49 & .93 \\
\hline $06 / 14 / 83$ & al & a/ & a/ & a/ & al & .66 & a) & .51 \\
\hline $07 / 05 / 83$ & 1.00 & .10 & .14 & .17 & .30 & .11 & .36 & .06 \\
\hline $08 / 04 / 83$ & .42 & .20 & .30 & .34 & .40 & .12 & .31 & .12 \\
\hline $09 / 18 / 83$ & 9.30 & .25 & .25 & .26 & .90 & .46 & .51 & .24 \\
\hline $10 / 09 / 83$ & 15.25 & .05 & .10 & .15 & 1.65 & .76 & .46 & .15 \\
\hline $11 / 22 / 83$ & 2.00 & .20 & .25 & .29 & .50 & .20 & .41 & .12 \\
\hline $12 / 03 / 83$ & 2.75 & .15 & .25 & .30 & .85 & .47 & .56 & .70 \\
\hline $02 / 26 / 84$ & 2.50 & .15 & .24 & .29 & .42 & .19 & .44 & .51 \\
\hline $03 / 04 / 84$ & 2.83 & .20 & .25 & .35 & .55 & .27 & .49 & .60 \\
\hline $03 / 12 / 84$ & 5.00 & .11 & .18 & .22 & .41 & .25 & .62 & .35 \\
\hline $05 / 18 / 84$ & 5.67 & .15 & .25 & .27 & .70 & .27 & .39 & .12 \\
\hline $06 / 05 / 84$ & 1.08 & .06 & .09 & .14 & .28 & .063 & .23 & .04 \\
\hline $06 / 12 / 84$ & .58 & .11 & .22 & .24 & .28 & .046 & .16 & .07 \\
\hline $07 / 24 / 84$ & 2.92 & .10 & .20 & .30 & .90 & .21 & .23 & .06 \\
\hline
\end{tabular}

a/ No rainfall avail able for storm. 
minute incremental rainfall and discharye at the inflow station is shown in figures 32-36. Differences in total discharge between the two stations or an analysis of the reduction in peak discharye was not determined.

Rainfall and inflow volumes, in inches, are summarized in table 12 and are plotted in fiyure 37 for the 19 selected storms. The ratio of runoff to rainfall for the inflow station is included in table 12. The runoff-rainfall ratio varied from 0.18 to 0.71 with a mean of 0.42 for the inflow station. The variation of the runoff-rainfall ratios appears to be evenly distributed about the mean ratio line.

\section{Quality of Water}

The Alta Vista area represents a nearly homoyeneous land use, a nousiny development that consists of 19 townhomes. Sampliny plans at this site were to collect streamflow and water-quality data at the inflow to a yrass swale that drains the eastern half of the study area and at an outflow station that would represent drainage from the entire study area. Streamflow data for the western half of the study area was to be estimated from streamflow data obtained on the eastern half of the study area. Because of similar land use, it was assumed that concentrations and densities of water-quality constituents for the western half of the study area could be estimated from values obtained from the eastern side. Because some runoff froril the western side of the study area did not stay within basin boundaries, it was not possible to determine total loads or total densities of bacteria at the outflow. However, streanflow records and water-quality data collected at the inflow and outflow sites probably were sufficient for compositiny discrete water-quality samples for the determination of discharge-weighted averaye concentrations or densities of constituents. Although accurate discharye data could not be obtained from the stayedischarye relation, the discharye data obtained, supplemented by unit runoff calculations provided data of sufficient accuracy to determine proportional amounts of discharye for compositiny discrete water samples. Consistant errurs in discharye over the hydroyraph will not affect discharye-weiyhted concentrations. Errors in discharye at one location on the hydroyraph will be masked or reduced because the discharye-weighted concentration is dependent on the total discharye of the composited sample.

The four discrete samples analyzed from each of five separate sturms also were assumed to be adeyuate to determine if measured peak concentrations or densities of constituents had been reduced between the inflow and outflow stations. Loss of water from the western drainaye channel would not adversely affect peak concentrations or densities of constituents at the outflow, because the concentrations in the water at the tilie of loss would be the same as the concentrations in the water that was retained.

Load removal efficiencies of water-yuality constituents could not be determined at the Alta Vista area because of inaccuracies in measuriny discharge at the outflow. 

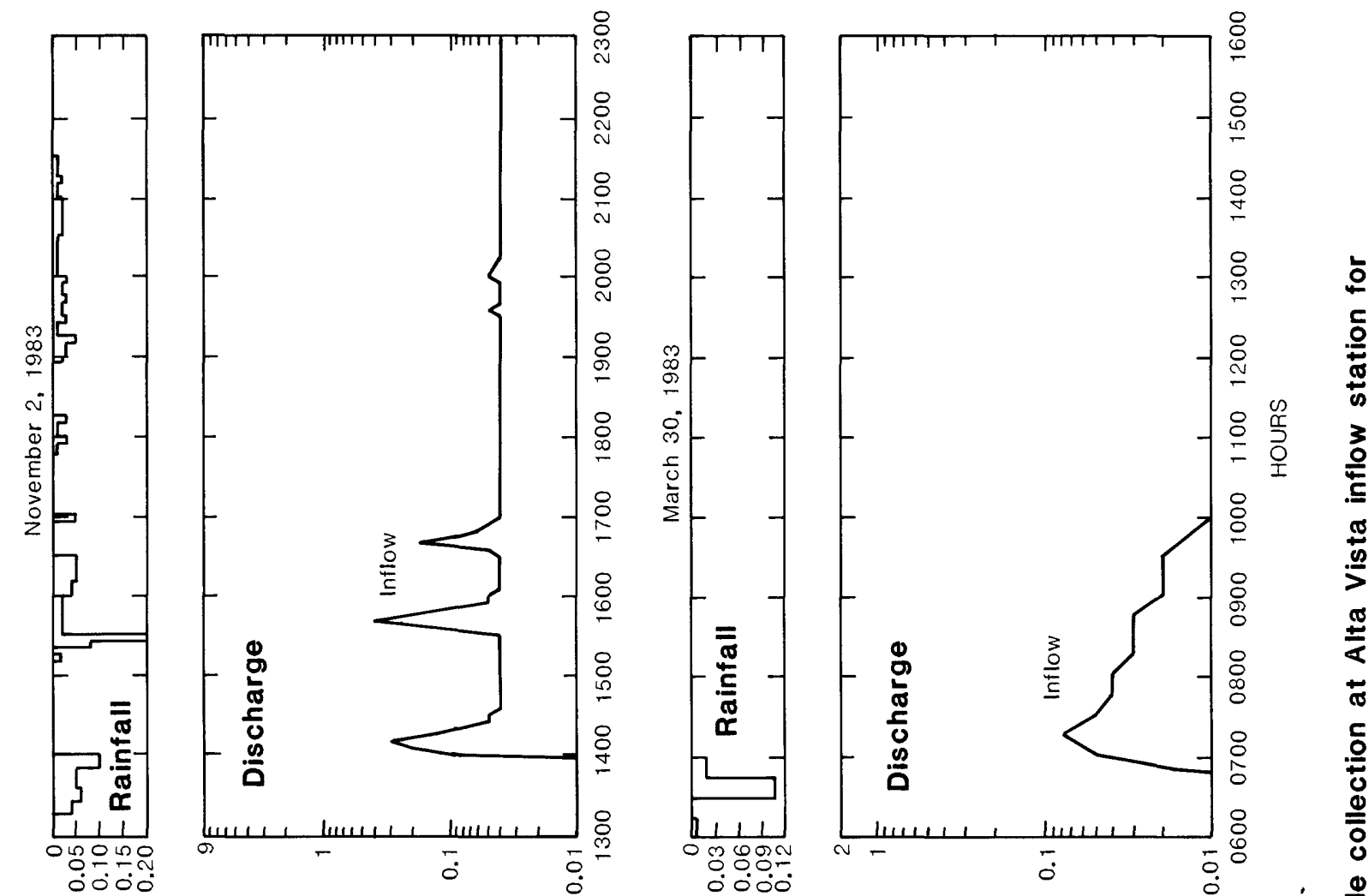

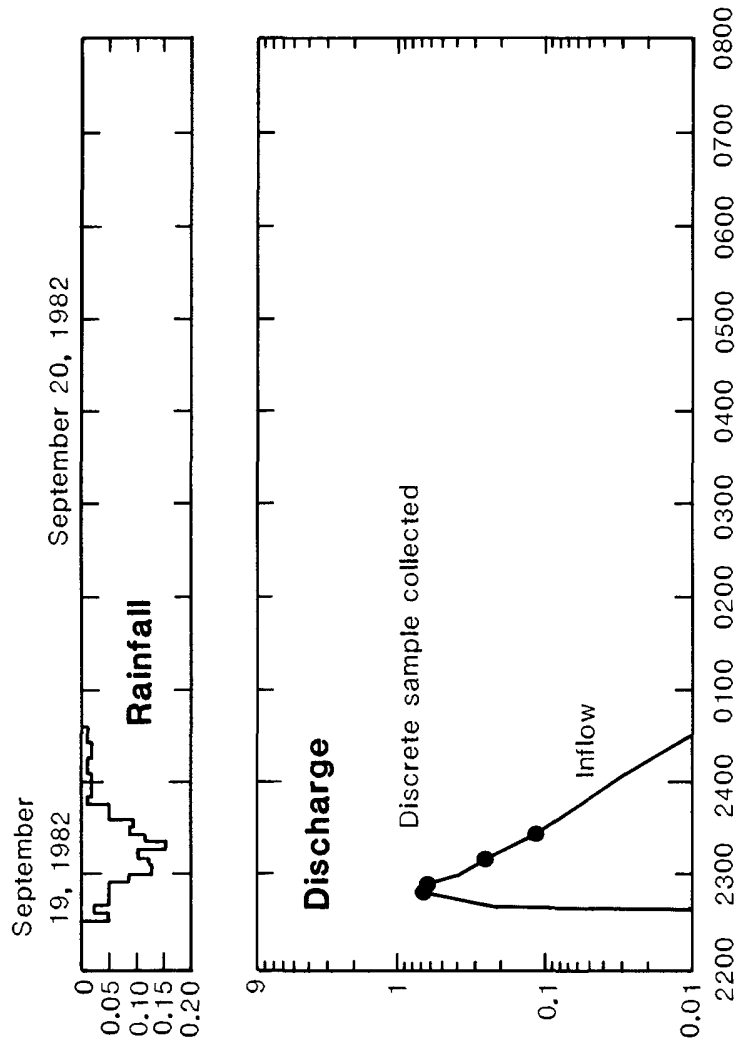

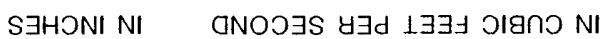
'T7 $\forall$ ANI $\forall$ C

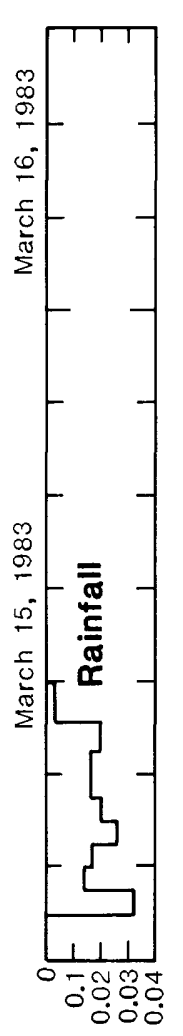

SBHONI NI ' $77 \forall \exists$ NIVY

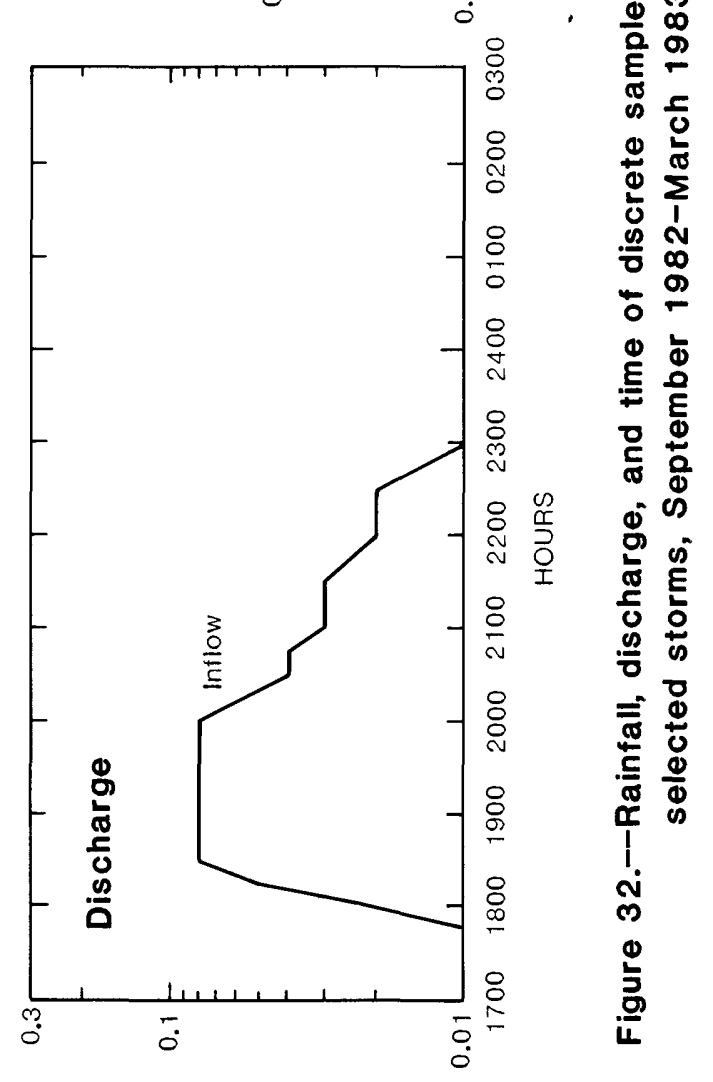

anOOJS y

‘ $\mathrm{OH} \forall \mathrm{HOSIO}$ 

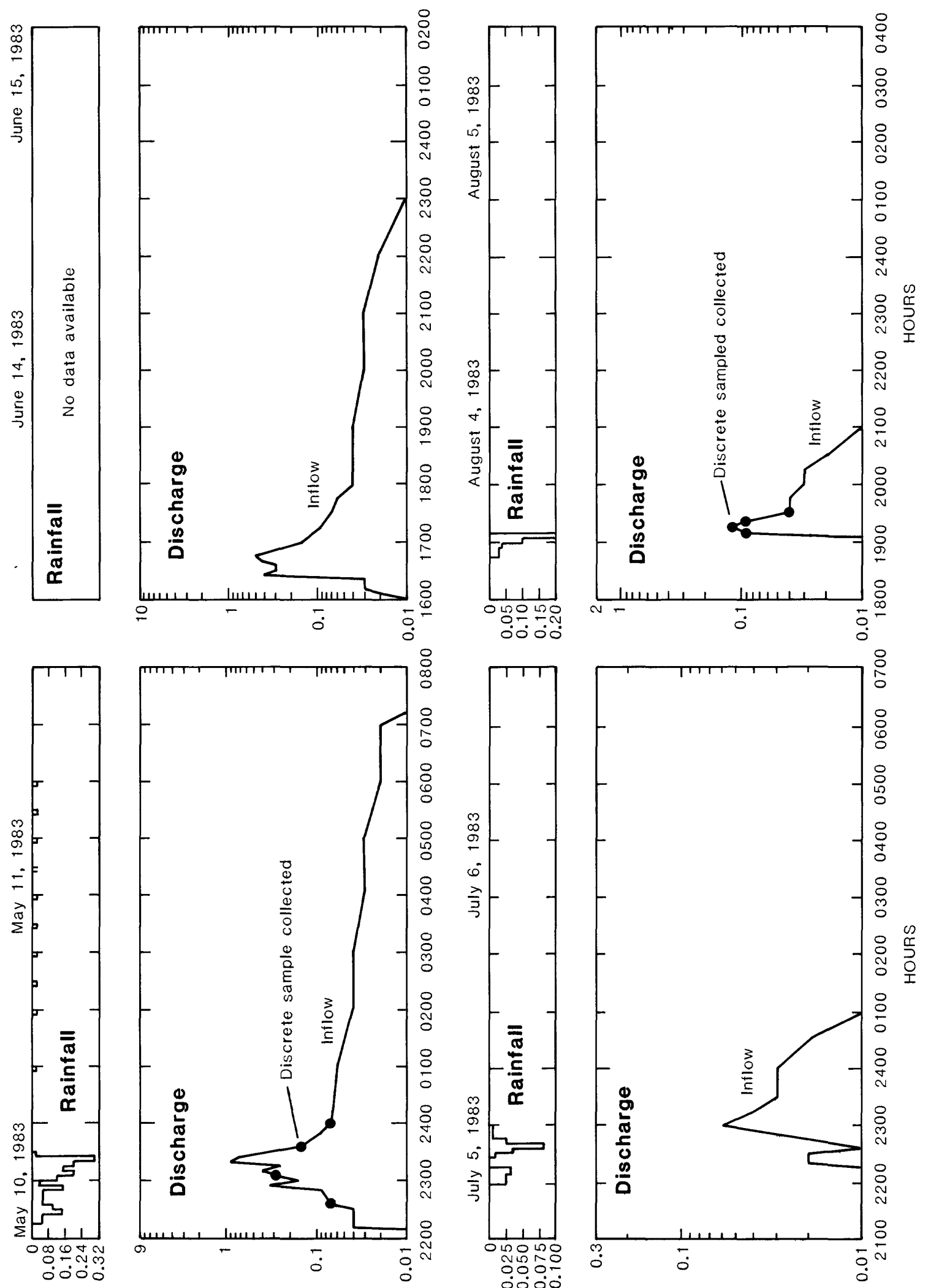

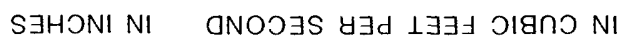
'าา $\forall \unlhd N I \forall Y$
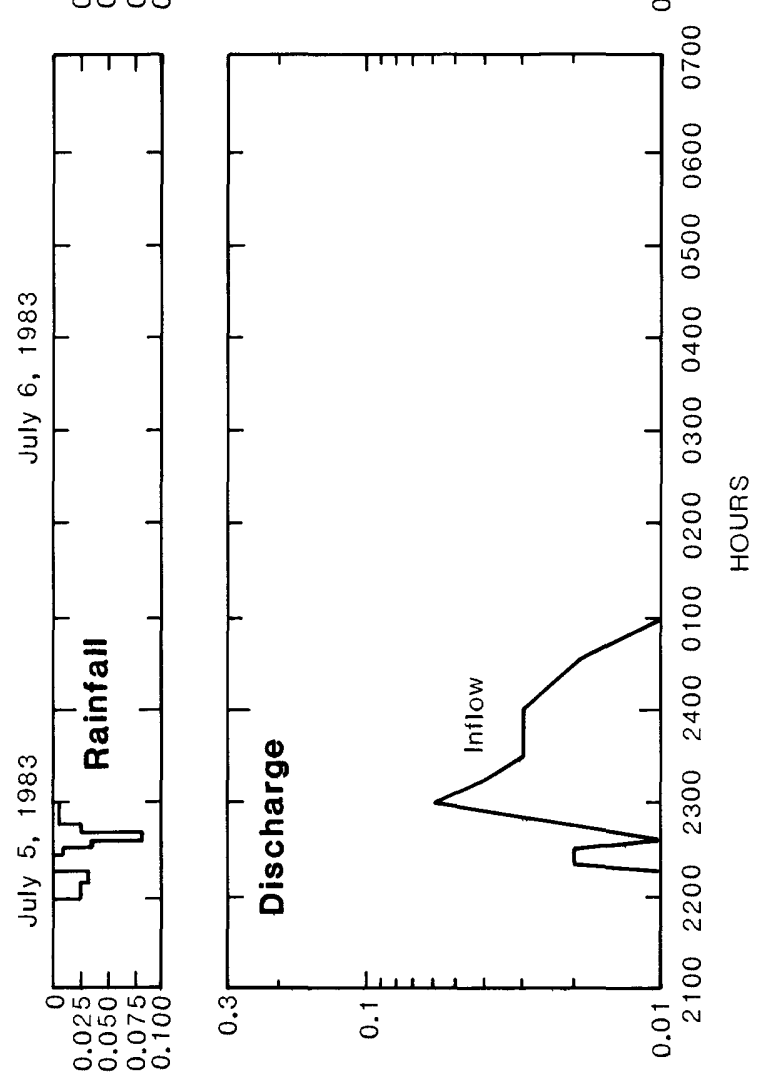

을

응

S $\exists$ HONI NI

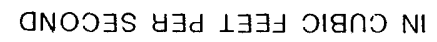

'า $\forall \unlhd N I \forall Y$

' $\exists$ Y $\forall$ HOSIO 

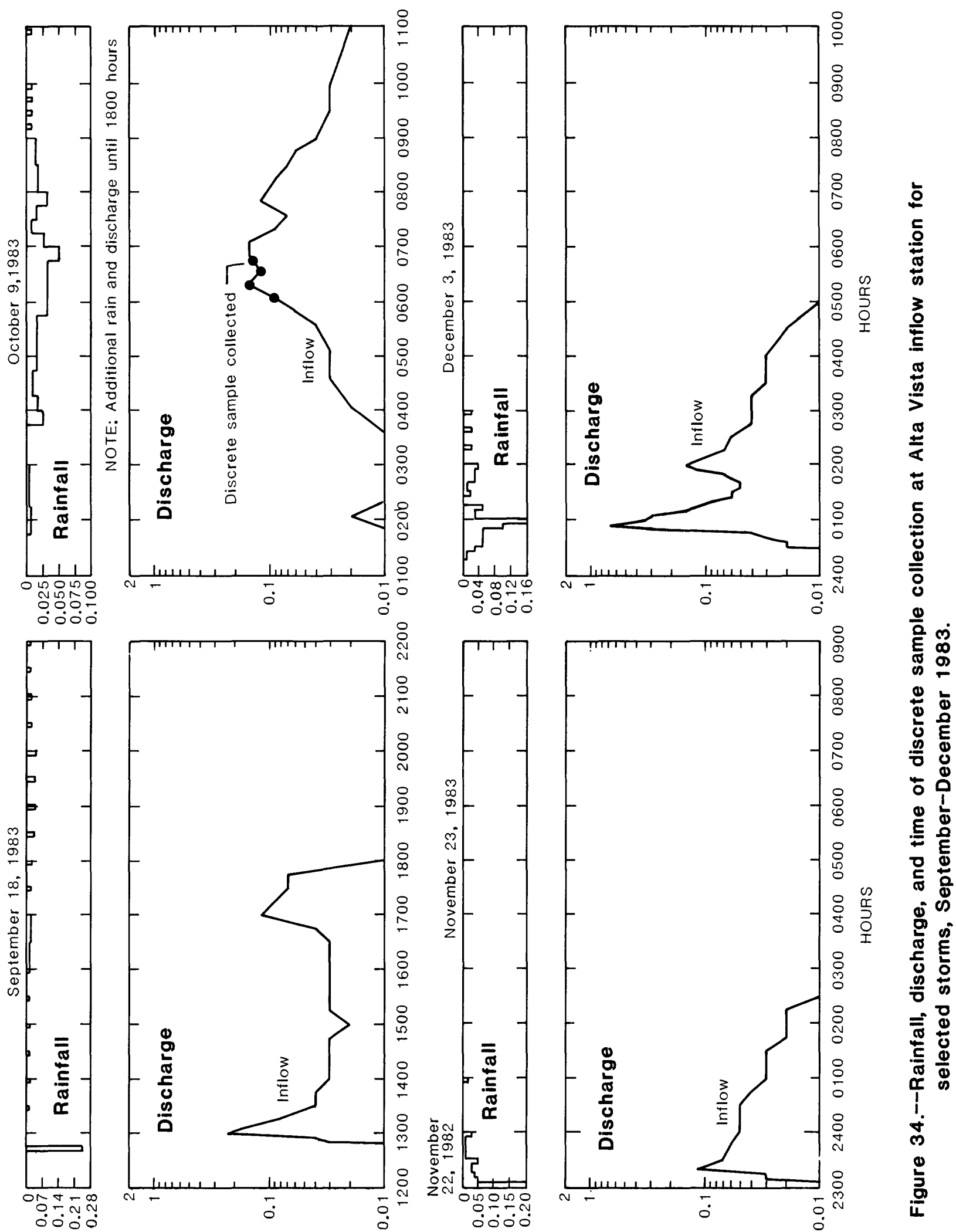

SBHONI NI

aNOJ $\exists S$ d $3 d$ 1 $1 \exists \exists \exists$ OIgกO NI $' 77 \forall \exists N I \forall Y$

‘ $\exists$ y $\forall$ HOSIa

SFHONI NI $' 77 \forall \exists N I \forall Y$
흐을

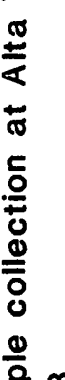

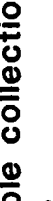

$\infty$

क ?

$\stackrel{0}{0}$

응

-

ह

ธิ

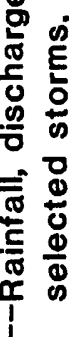

;

은 

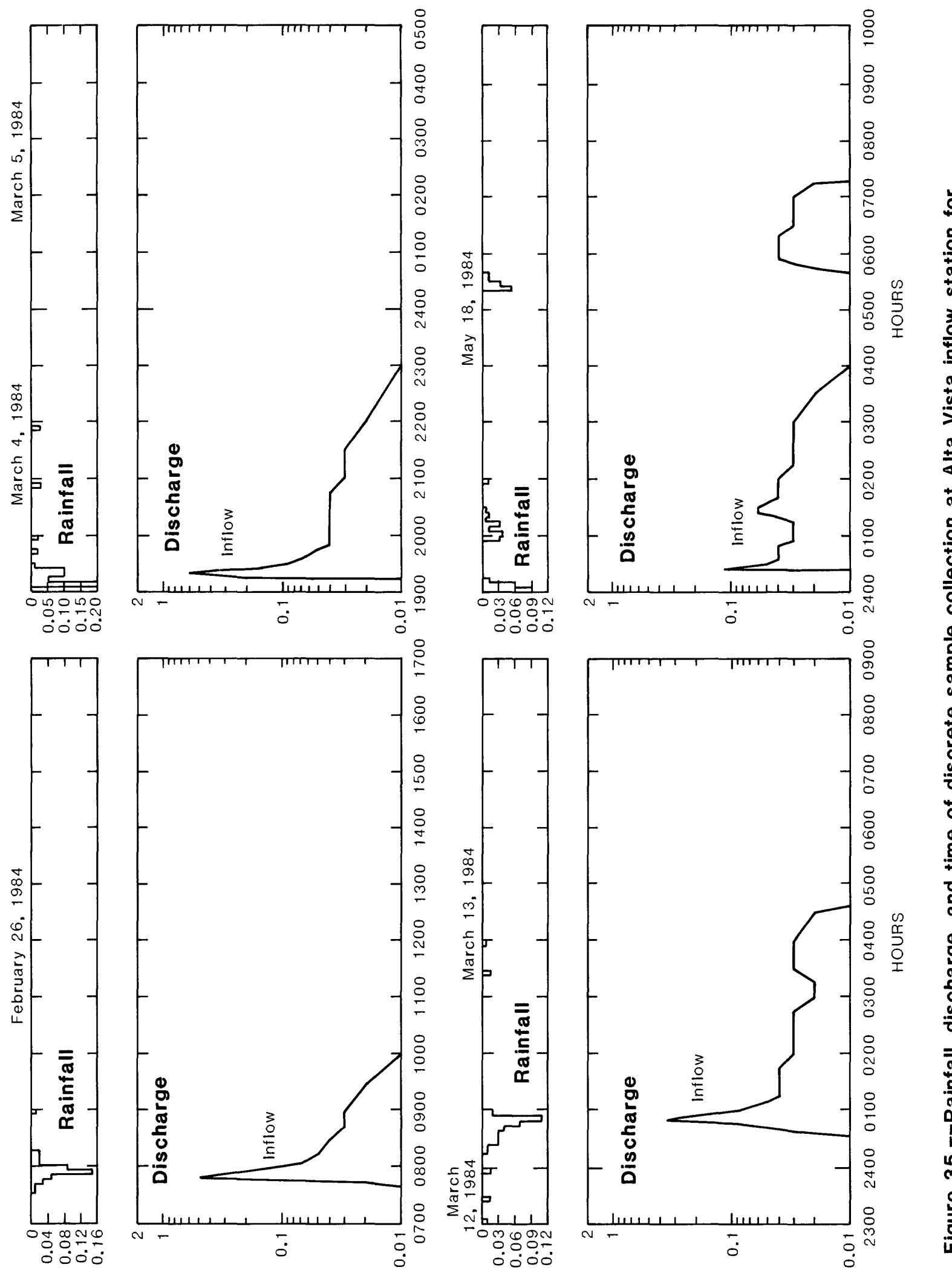

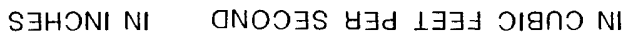
' 7 $\forall J N I \forall Y$

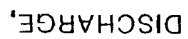
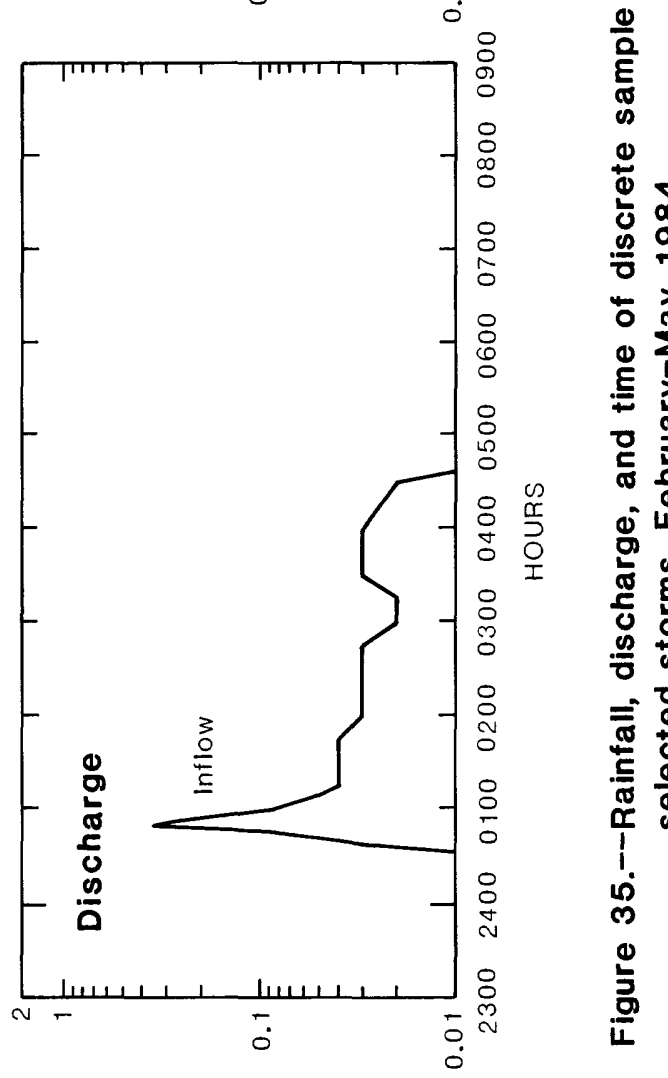

SᄏHONI NI ONOO

$' 77 \forall J N I \forall \forall$

‘⿹勹HHOSIO 


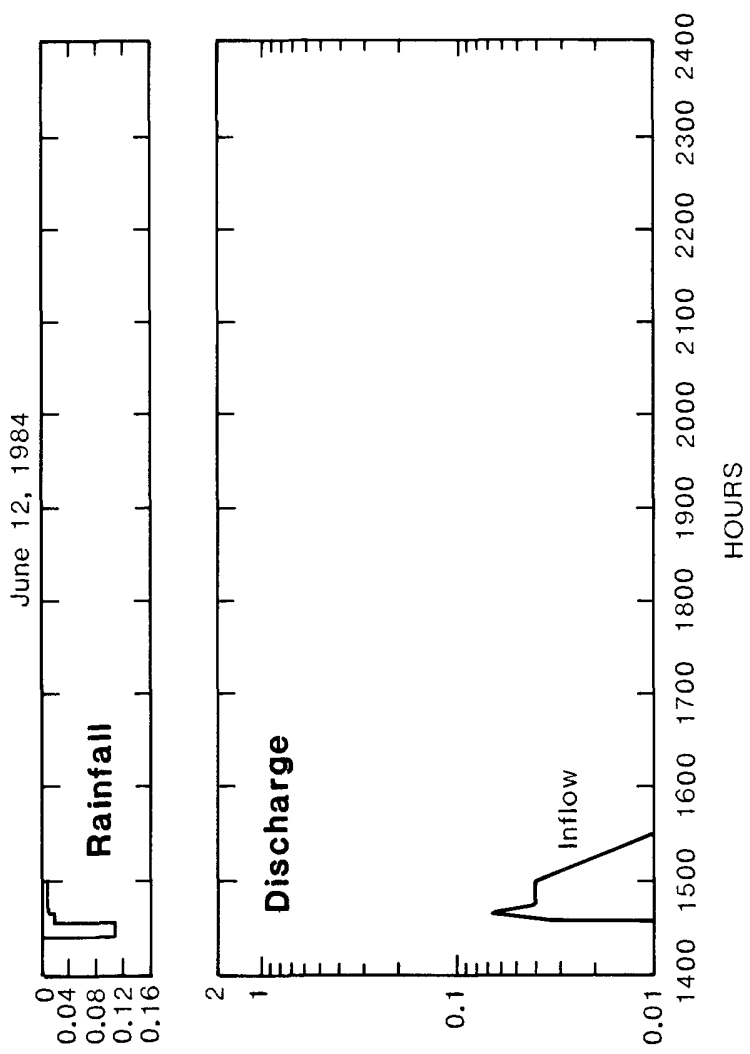

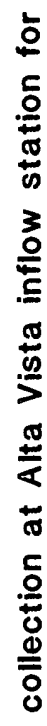
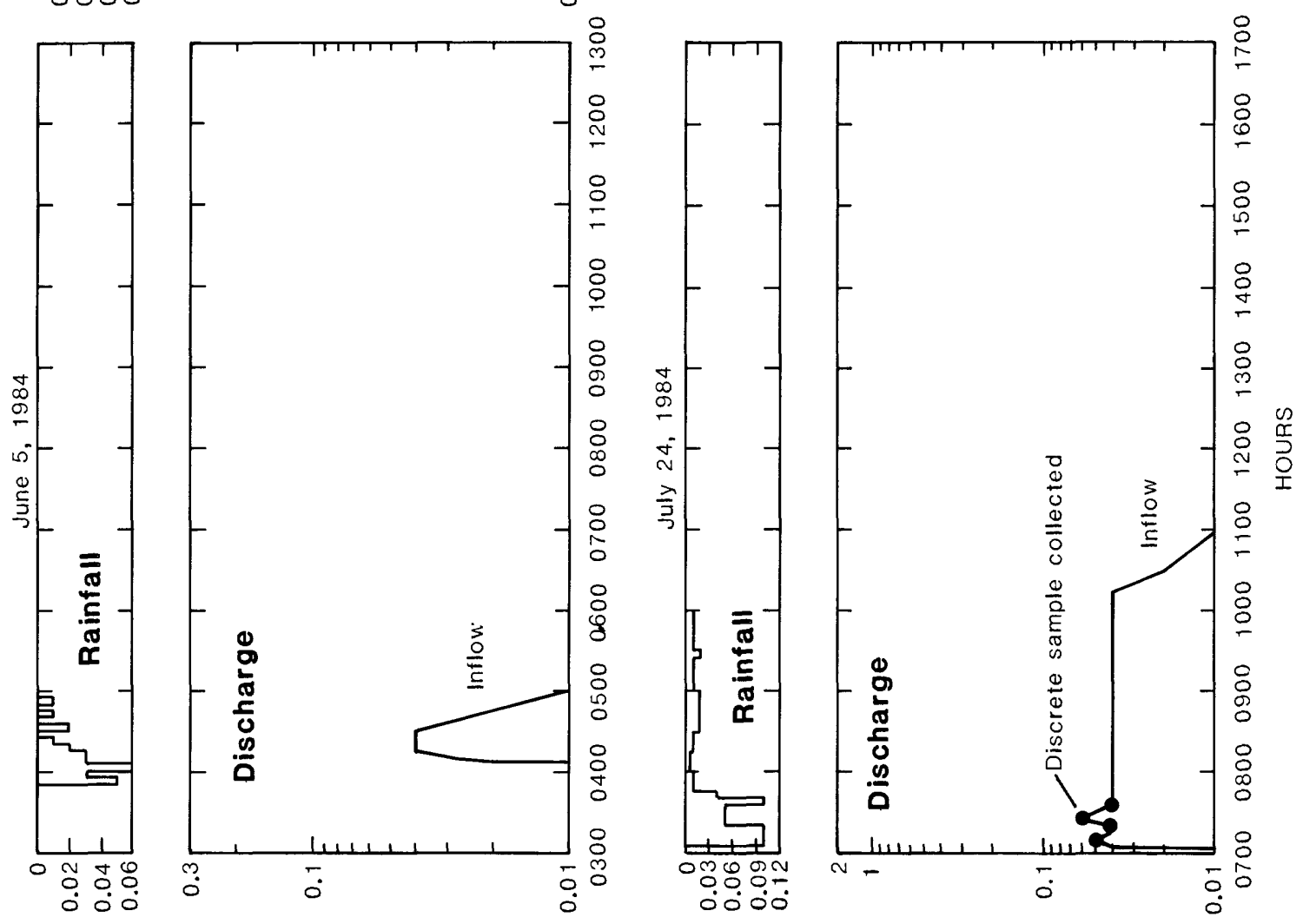

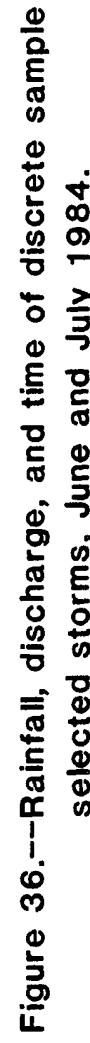

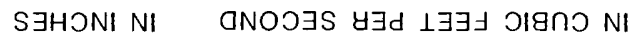

\urcorner $7 \forall \unlhd N I \forall Y$ ' $\exists$ Y $\forall$ HOSIO

SЭHONI NI $\neg 7 \forall \unlhd N i \forall Y$
aNOO $\exists S$ y 4 d $1 \exists \exists \exists$ JIgกO NI

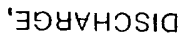




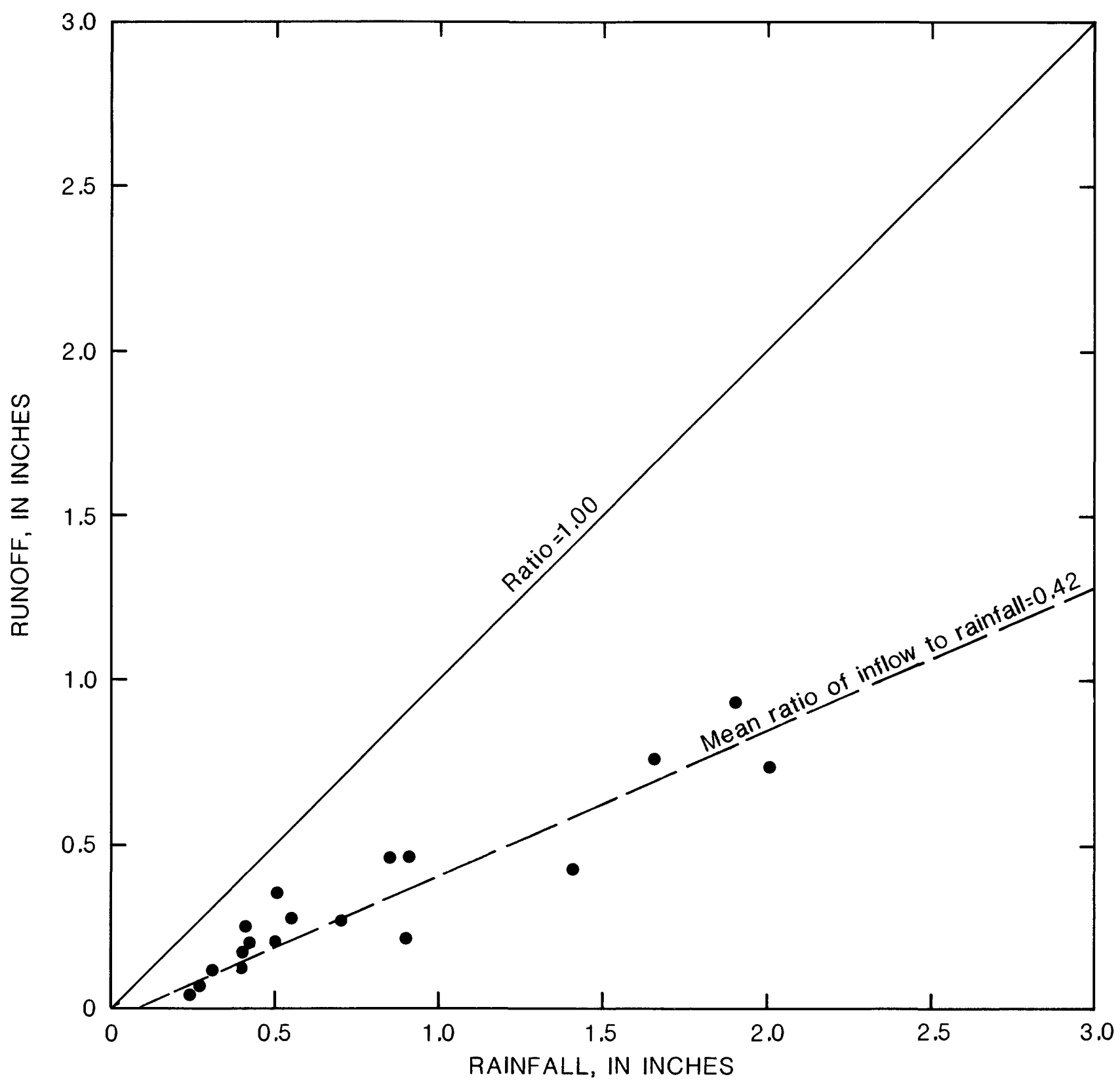

Figure 37.-- Relationship between storm rainfall and runoff volumes at the Alta Vista inflow station. 


\section{Discharge-Weighted Concentrations}

Discharge-weighted concentration data for the Alta Vista area are presented in figures 38-42 and in tables 13 and 14 . The data show that only relatively small variations in concentrations and densities of water-quality constituents exist between the inflow and outflow gages for most storms. Little variation is noted in discharge-weighted densities of fecal-coliform bacteria between the inflow and outflow gages (fig. 38). Discharge-weighted densities of fecalstreptococci bacteria were larger in the inflow than in the outflow for 14 of the 19 storms analyzed (fig. 38).

Discharge-weighted concentrations of BOD, COD, and TOC were smaller in the inflow than in the outflow for at least 12 of the 19 storms analyzed (fig. 39). Discharge-weighted concentrations of dissolved solids and volatile dissolved solids were smaller in the inflow than in the outflow for at least 16 of the 19 storms analyzed (fig. 40). Data indicate that discharge-weighted concentrations of suspended solids generally were small, and that concentrations in the inflow were larger than those in the outflow for approximately two-thirds of the storms analyzed.

Little variation was noted in discharge-weighted concentrations of total nitrogen, total organic plus ammonia nitrogen, and total nitrite plus nitrogen between the inflow and outflow stations (fig. 41). Although discharge-weighted concentrations of these constituents were smaller in the inflow than in the outflow stations, differences commonly were only a few tenths of a milligram per liter. Discharge-weighted concentrations of total phosphorus were 1 arger in the outflow than in the inflow station for every storm analyzed (fig. 41).

Little variation was noted in discharge-weighted concentrations of trace elements between the inflow and the outflow stations (fig. 42). Approximately one-half of the discharge-weighted concentrations of dissolved iron and dissolved zinc were equal or larger in the outflow than in the inflow station. Concentrations of dissolved lead generally were smaller in the outflow than in the inflow stations, however, differences commoniy were only 1 or $2 \mu \mathrm{g} / \mathrm{L}$. Analyses for lead for seven storms are not shown in fig. 43 because the concentrations were less than detection limits. Cadmium was less than the detection limits for every storm analyzed except for the storm of June 5, 1984, which had a discharge-weighted concentration of $1 \mathrm{\mu g} / \mathrm{L}$ at the inflow station.

Because of the relatively small variations in concentrations and densities of constituents between the inflow and outflow sites, and because of the errors in discharge at the outflow gage, it is not feasible to determine the effect of the grass-covered swales on discharge-weighted concentrations and densities of water-quality constituents.

\section{Measured Peak Concentrations}

The timing of the collection of discrete water samples at the inflow station in relation to the inflow hydrograph for five storms at Alta Vista is shown in figures $32,33,34$, and 36. Discrete water samples were collected at or near the peak discharge for the inflow station and throughout the hydrograph at the outfiow station. Measured peak densities of fecal-coliform bacteria 

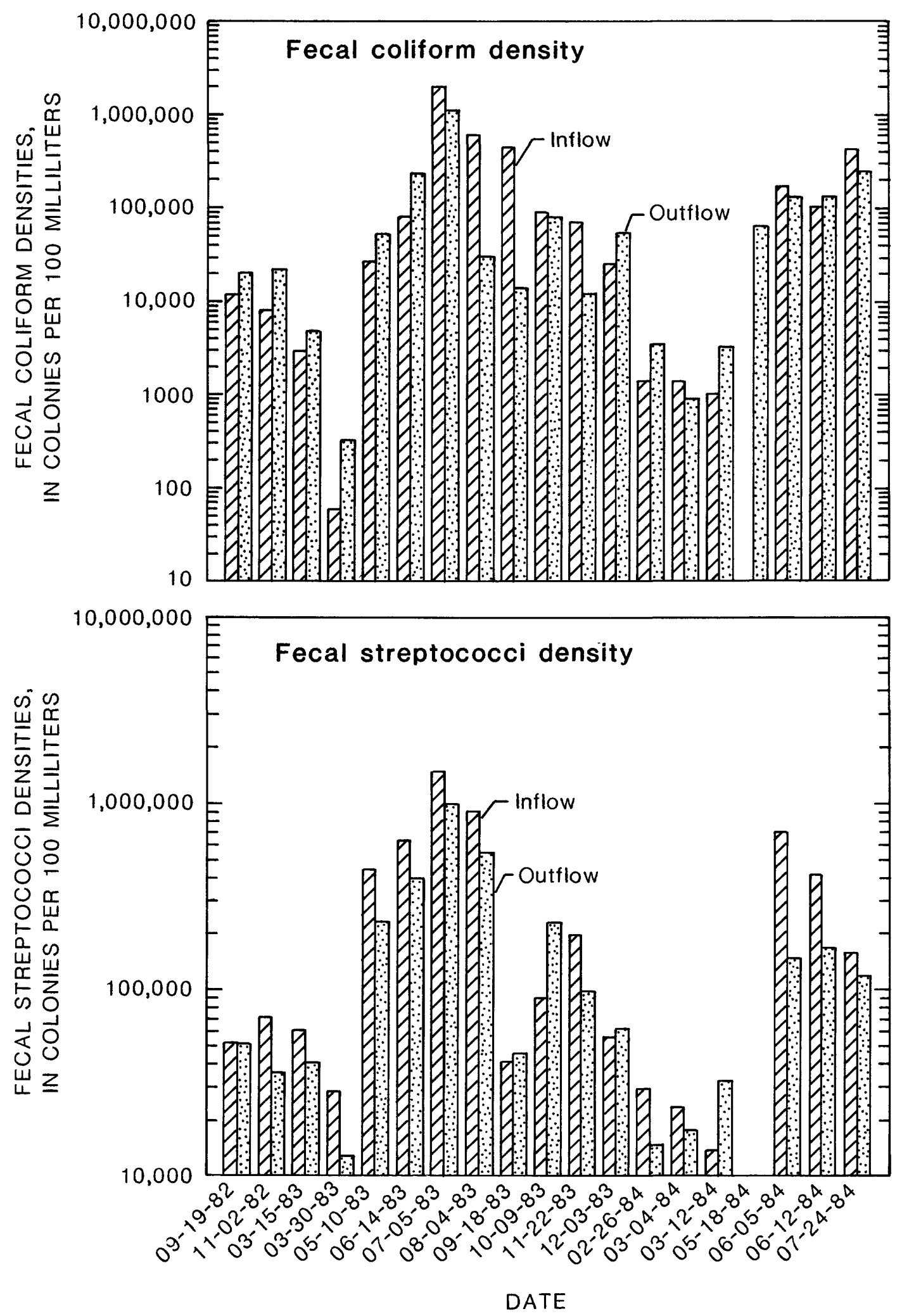

Figure 38.--Densities of fecal-coliform and fecal-streptococci bacteria in the inflow and outflow at Alta Vista. 

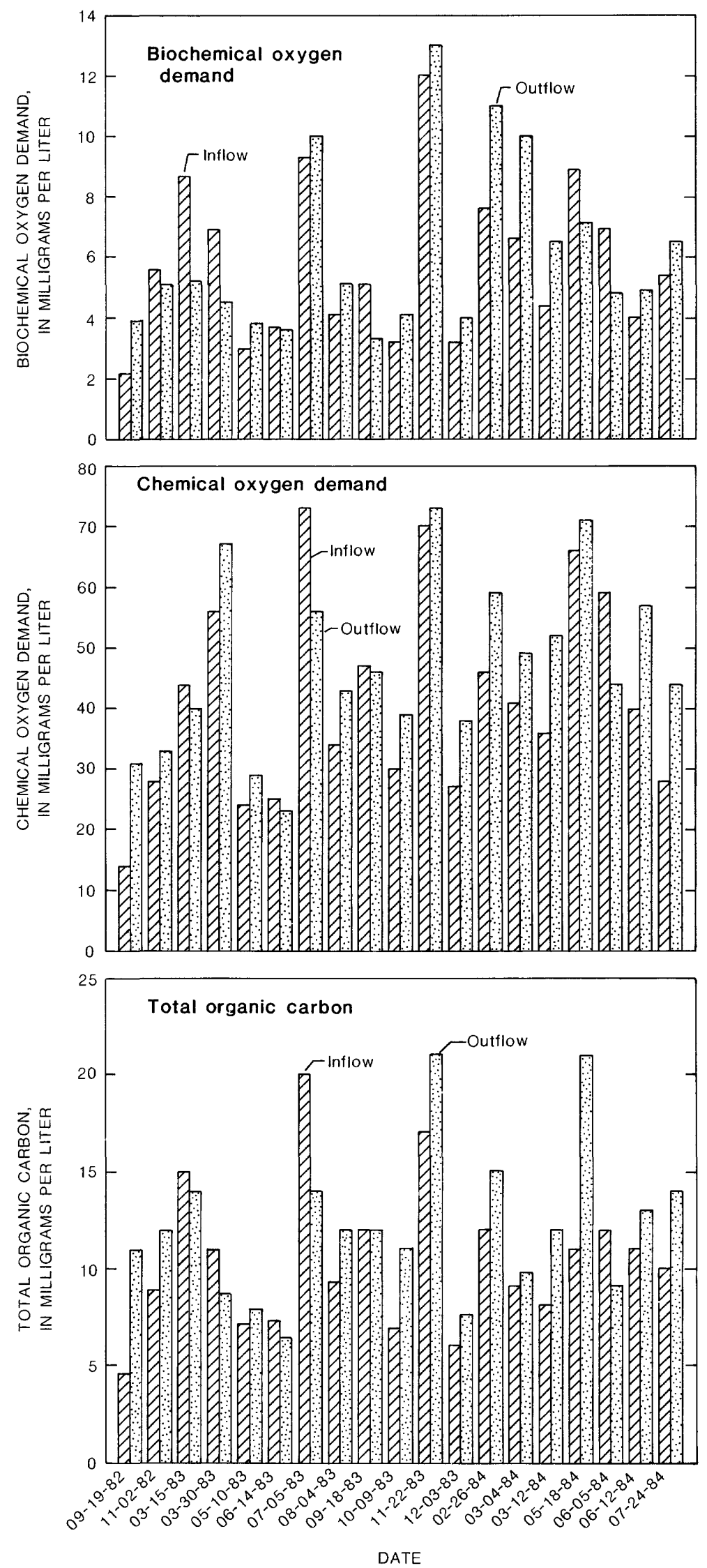

Figure 39.--Discharge-weighted concentrations of biochemical oxygen demand, chemical oxygen demand, and total organic carbon in the inflow and outflow at Alta Vista. 

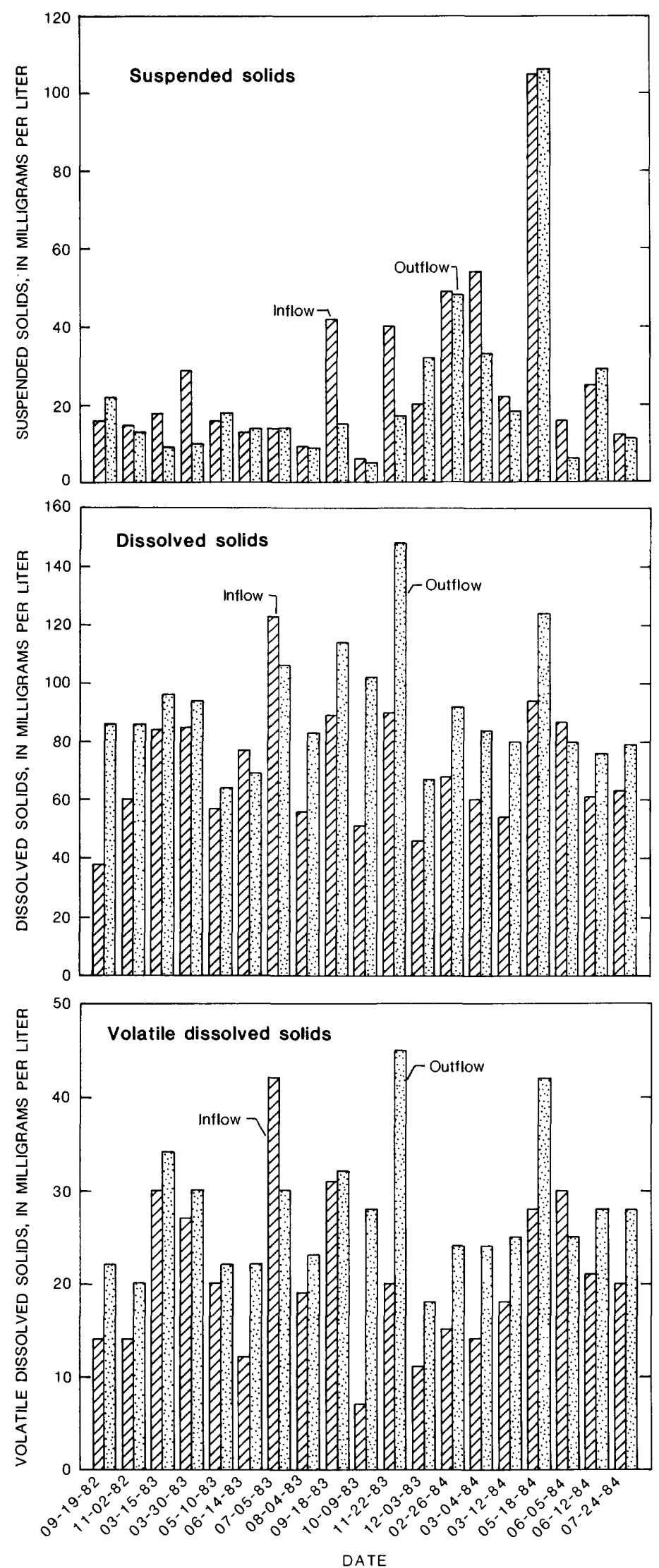

Figure 40.--Discharge-weighted concentrations of suspended solids, dissolved solids, and volatile dissolved solids in the inflow and outflow at Alta Vista. 

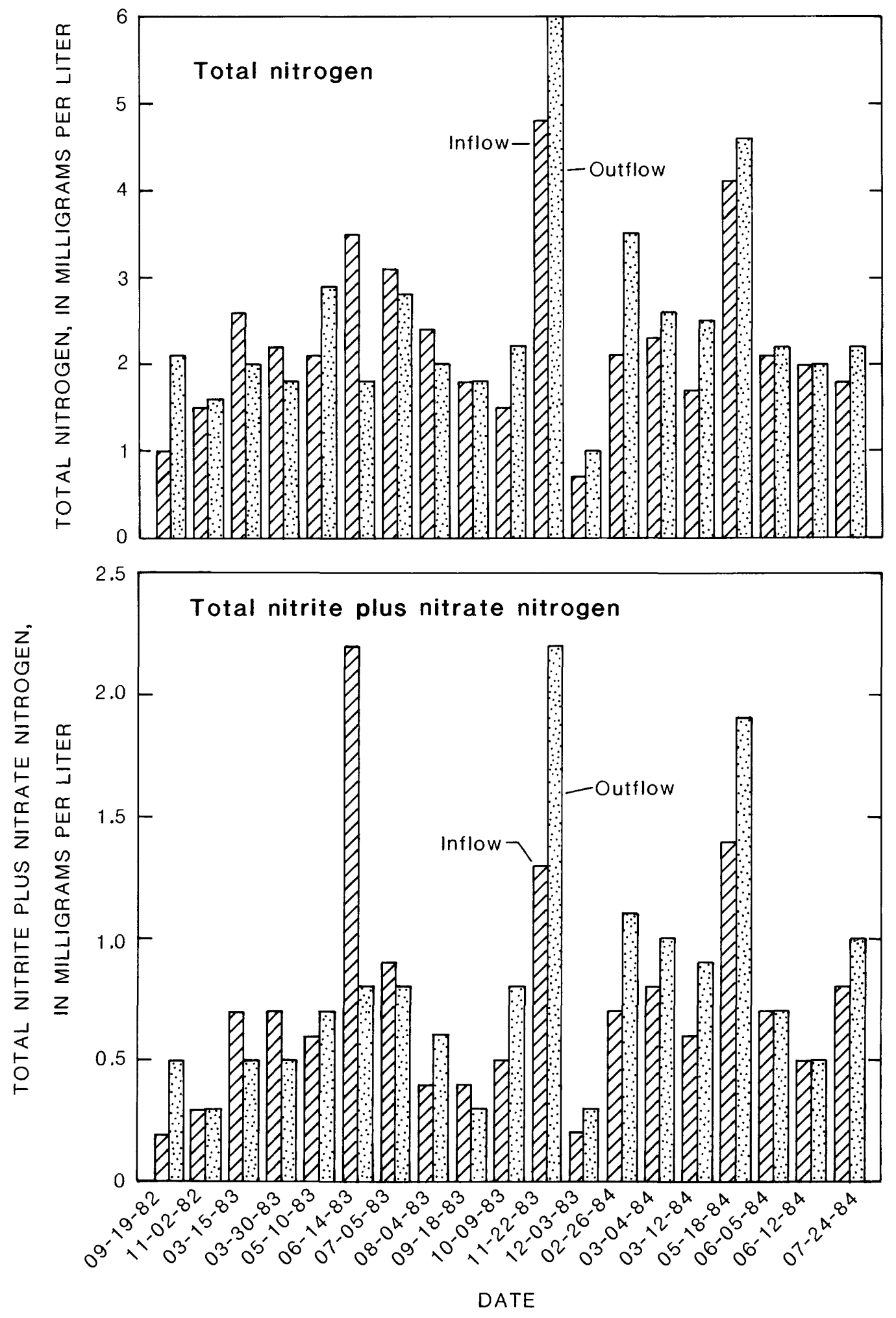

Figure 41.--Discharge-weighted concentrations of total nitrogen, total organic plus ammonia nitrogen, total nitrite plus nitrate nitrogen, and total phosphorus in the inflow and outflow at Alta Vista. (Figure 41 continued on next page) 

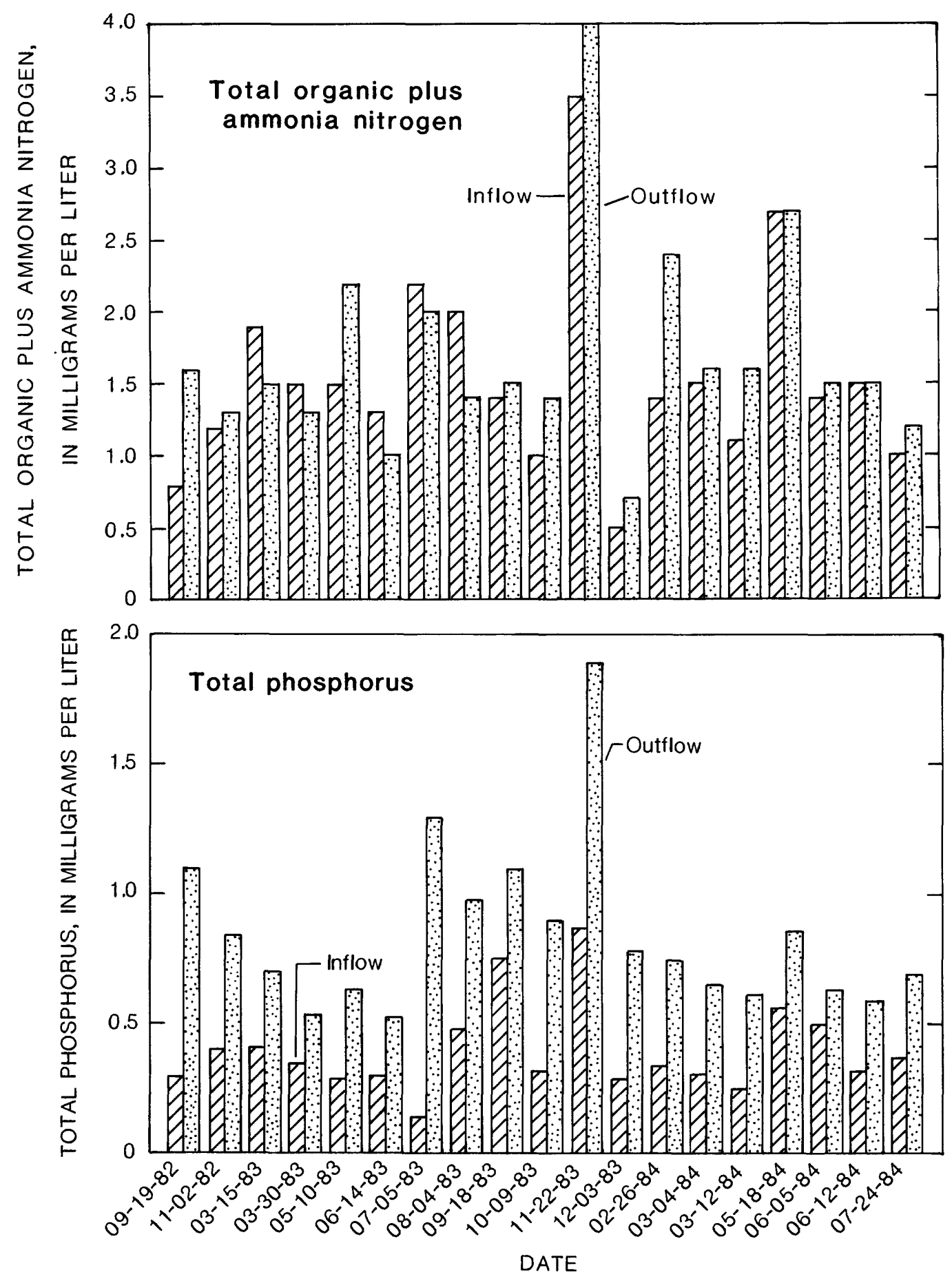

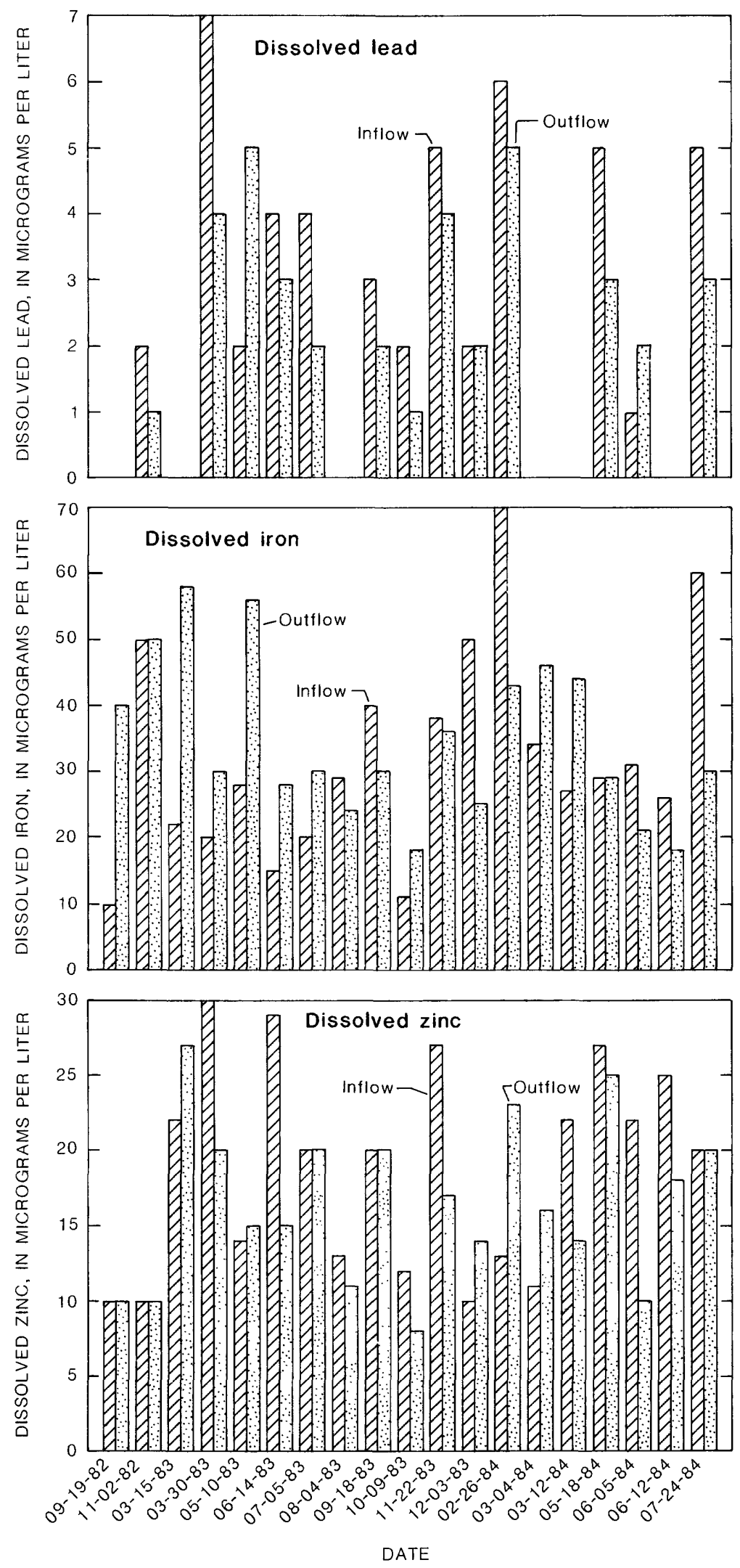

Figure 42.--Discharge-weighted concentrations of dissolved lead, dissolved iron, and dissolved zinc in the inflow and outflow at Alta Vista. 
Table 13.- - Water analyses of the inflow at Alta Vista

$\left[\mathrm{ft}^{3} / \mathrm{s}\right.$, cubic foot per second; $\mu \mathrm{S} / \mathrm{cm}$, microsiemens per centimeter at 25 degrees Celsius; mg/L, milligram per liter; cols./100 mL, colonies per $100 \mathrm{milliliters;} K$, non-ideal colony count; $. \mathrm{g} / \mathrm{h}$, microgram per liter]

08154660 Mayfield Creek at Alta Verde Orive at Austin, Texas

\begin{tabular}{|c|c|c|c|c|c|c|c|c|c|c|}
\hline Date & Time & $\begin{array}{c}\text { Mean } \\
\text { sample } \\
\text { dis- } \\
\text { charge } \\
\left(\mathrm{ft}^{3} / \mathrm{s}\right)\end{array}$ & $\begin{array}{c}\text { Instan- } \\
\text { taneous } \\
\text { sample } \\
\text { dis- } \\
\text { charge } \\
\left(\mathrm{ft}^{3} / \mathrm{s}\right)\end{array}$ & $\begin{array}{l}\text { Spe- } \\
\text { cific } \\
\text { con- } \\
\text { duct- } \\
\text { ance } \\
(\mu S / c m)\end{array}$ & $\begin{array}{l}\text { Oxygen } \\
\text { demand, } \\
\text { chem- } \\
\text { ical } \\
\text { (high } \\
\text { level) } \\
\text { (mg/L) } \\
\end{array}$ & $\begin{array}{l}\text { Oxygen } \\
\text { demand, } \\
\text { bio- } \\
\text { chem- } \\
\text { ical, } \\
5 \mathrm{day} \\
(\mathrm{mg} / \mathrm{L}) \\
\end{array}$ & $\begin{array}{l}\text { Coli- } \\
\text { form, } \\
\text { fecal, } \\
0.7 \\
\text { UM-MF } \\
\text { (col s./ } \\
100 \mathrm{~mL} \text { ) }\end{array}$ & $\begin{array}{l}\text { Strep- } \\
\text { tococci } \\
\text { fecal, } \\
\mathrm{KF} \mathrm{Agar} \\
(\operatorname{col~s./} \\
100 \mathrm{~mL})\end{array}$ & $\begin{array}{c}\text { Solids, } \\
\text { residue } \\
\text { at } \\
180^{\circ} \mathrm{C}, \\
\text { dis- } \\
\text { solved } \\
(\mathrm{mg} / \mathrm{L}) \\
\end{array}$ & $\begin{array}{l}\text { Solids, } \\
\text { residue } \\
\text { at } \\
105^{\circ} \mathrm{C}, \\
\text { sus- } \\
\text { pended } \\
\text { (mg/L) }\end{array}$ \\
\hline $\begin{array}{c}\text { Sept. } 1982 \\
19-20 \\
19 \ldots \\
19 \ldots \\
19 \ldots \\
19 \ldots\end{array}$ & $\begin{array}{l}2235-2400 \\
2250 \\
2257 \\
2312 \\
2327\end{array}$ & $\begin{array}{l}0.22 \\
-- \\
-- \\
-- \\
--\end{array}$ & $\begin{array}{l}-- \\
0.67 \\
0.62 \\
0.58 \\
0.46\end{array}$ & $\begin{array}{l}53 \\
93 \\
47 \\
46 \\
54\end{array}$ & $\begin{array}{l}14 \\
62 \\
34 \\
28 \\
17\end{array}$ & $\begin{array}{l}2.2 \\
7.2 \\
3.8 \\
2.6 \\
1.6\end{array}$ & $\begin{array}{r}12,000 \\
\mathrm{~K} 12,000 \\
14,000 \\
12,000 \\
21,000\end{array}$ & $\begin{array}{r}53,000 \\
120,000 \\
59,000 \\
47,000 \\
43,000\end{array}$ & $\begin{array}{l}38 \\
70 \\
38 \\
38 \\
36\end{array}$ & $\begin{array}{r}16 \\
81 \\
48 \\
10 \\
9\end{array}$ \\
\hline Nov. $02-02$ & $1355-2400$ & 0.05 & $\cdots$ & 78 & 28 & 5.6 & 8,000 & 72,000 & 60 & 15 \\
\hline $\begin{aligned} \text { Mar. } & 1983 \\
& 15-15 \\
& 30-30\end{aligned}$ & $\begin{array}{l}1725-2400 \\
0615-1200\end{array}$ & $\begin{array}{l}0.04 \\
0.02\end{array}$ & -- & $\begin{array}{l}103 \\
124\end{array}$ & $\begin{array}{l}44 \\
56\end{array}$ & $\begin{array}{l}8.7 \\
6.9\end{array}$ & $\begin{array}{r}2,900 \\
K 60\end{array}$ & $\begin{array}{l}62,000 \\
29,000\end{array}$ & $\begin{array}{l}84 \\
35\end{array}$ & $\begin{array}{l}18 \\
29\end{array}$ \\
\hline $\begin{array}{l}10-11 \\
10 \ldots \\
10 \ldots \\
10 \ldots \\
10 \ldots\end{array}$ & $\begin{array}{l}2205-0300 \\
2235 \\
2305 \\
2335 \\
2358\end{array}$ & $\begin{array}{l}0.07 \\
-- \\
-- \\
-- \\
--\end{array}$ & $\begin{array}{l}-- \\
0.07 \\
0.29 \\
0.15 \\
0.08\end{array}$ & $\begin{array}{r}77 \\
165 \\
51 \\
56 \\
112\end{array}$ & $\begin{array}{l}24 \\
83 \\
19 \\
19 \\
28\end{array}$ & $\begin{array}{l}3.0 \\
5.7 \mathrm{~K} \\
3.2 \\
2.8 \\
3.4\end{array}$ & $\begin{array}{r}27,000 \\
150,000 \\
25,000 \\
23,000 \\
53,000\end{array}$ & $\begin{array}{r}K 450,000 \\
K 1,400,000 \\
460,000 \\
K 260,000 \\
K 770,000\end{array}$ & $\begin{array}{r}57 \\
141 \\
53 \\
49 \\
87\end{array}$ & $\begin{array}{r}16 \\
101 \\
26 \\
19 \\
14\end{array}$ \\
\hline June $14-14$ & $1605-2400$ & 0.06 & -- & 123 & 25 & 3.7 & 80,000 & 640,000 & 77 & 13 \\
\hline${ }^{\text {July }}$ 05-06 & $2210-0100$ & 0.03 & -- & 155 & 73 & 9.32 & 2000,000 & $1,500,000$ & 123 & 14 \\
\hline $\begin{array}{l}\text { Aug. } \\
\begin{array}{l} \\
04-04 \\
04 \ldots \\
04 \ldots \\
04 \ldots \\
04 \ldots\end{array}\end{array}$ & $\begin{array}{l}1900-2100 \\
1910 \\
1914 \\
1921 \\
1928\end{array}$ & $\begin{array}{l}0.04 \\
-- \\
-- \\
-- \\
--\end{array}$ & $\begin{array}{l}- \\
0.09 \\
0.12 \\
0.09 \\
0.04\end{array}$ & $\begin{array}{l}75 \\
75 \\
74 \\
73 \\
76\end{array}$ & $\begin{array}{l}34 \\
55 \\
40 \\
31 \\
30\end{array}$ & $\begin{array}{l}4.1 \\
7.5 \\
5.2 \\
4.0 \\
4.6\end{array}$ & $\begin{array}{r}590,000 \\
440,000 \\
260,000 \\
\mathrm{~K} 10,000 \\
74,000\end{array}$ & $\begin{array}{r}920,000 \\
\mathrm{~K} 1,000,000 \\
880,000 \\
220,000 \\
200,000\end{array}$ & $\begin{array}{l}56 \\
63 \\
60 \\
57 \\
55\end{array}$ & $\begin{array}{r}9 \\
40 \\
15 \\
10 \\
8\end{array}$ \\
\hline${ }_{18-18}$ & $1245-2400$ & 0.03 & -- & 109 & 47 & 5.1 & 440,000 & 42,000 & 89 & 42 \\
\hline $\begin{array}{c}\text { oct. } \\
09-09 \\
09 \ldots \\
09 . . \\
09 . . \\
09 . .\end{array}$ & $\begin{array}{l}0150-1700 \\
0603 \\
0615 \\
0630 \\
0642\end{array}$ & $\begin{array}{l}0.03 \\
-- \\
-- \\
-- \\
--\end{array}$ & $\begin{array}{l}-- \\
0.09 \\
0.15 \\
0.12 \\
0.13\end{array}$ & $\begin{array}{r}35 \\
105 \\
93 \\
77 \\
72\end{array}$ & $\begin{array}{l}30 \\
33 \\
33 \\
28 \\
24\end{array}$ & $\begin{array}{l}3.2 \\
5.7 \mathrm{~K} \\
4.3 \\
3.5 \\
2.7\end{array}$ & $\begin{array}{r}98,000 \\
\times 170,000 \\
440,000 \\
200,000 \\
74,000\end{array}$ & $\begin{array}{r}92,000 \\
92,000 \\
84,000 \\
200,000 \\
86,000\end{array}$ & $\begin{array}{l}51 \\
69 \\
58 \\
43 \\
44\end{array}$ & $\begin{array}{l}6 \\
5 \\
4 \\
2 \\
2\end{array}$ \\
\hline Nov. $22-23$ & $2300-0300$ & 0.04 & -- & 143 & 70 & 12 & 68,000 & 200,000 & 90 & 40 \\
\hline Dec. $03-03$ & $0025-0515$ & 0.07 & -- & 59 & 27 & 3.2 & $\mathrm{~K} 25,000$ & 57,000 & 46 & 20 \\
\hline Feb. $\begin{array}{l}1984 \\
26-26\end{array}$ & $0735-1000$ & 0.05 & -- & 70 & 46 & 7.6 & 1,400 & 30,000 & 63 & 49 \\
\hline $\begin{array}{r}\text { Mar. } \\
04-04 \\
12-12\end{array}$ & $\begin{array}{l}1910-2400 \\
0001-0500\end{array}$ & $\begin{array}{l}0.04 \\
0.04\end{array}$ & -- & $\begin{array}{l}70 \\
70\end{array}$ & $\begin{array}{l}41 \\
36\end{array}$ & $\begin{array}{l}0.6 \\
4.4\end{array}$ & $\begin{array}{r}\times 1,400 \\
1,000\end{array}$ & $\begin{array}{l}24,000 \\
14,000\end{array}$ & $\begin{array}{l}50 \\
54\end{array}$ & $\begin{array}{l}54 \\
22\end{array}$ \\
\hline $18-18$ & $0020-0720$ & 0.03 & -- & 120 & 66 & -- & - & $>100,000$ & 93 & 105 \\
\hline $\begin{array}{r}\text { June } \\
\begin{array}{l}05-05 \\
12-12\end{array}\end{array}$ & $\begin{array}{l}0400-0700 \\
1430-1545\end{array}$ & $\begin{array}{l}0.02 \\
0.02\end{array}$ & -- & $\begin{array}{r}125 \\
71\end{array}$ & $\begin{array}{l}59 \\
40\end{array}$ & $\begin{array}{l}6.9 k \\
4.0\end{array}$ & $\begin{array}{r}K 170,000 \\
100,000\end{array}$ & $\begin{array}{l}720,000 \\
420,000\end{array}$ & $\begin{array}{l}87 \\
61\end{array}$ & $\begin{array}{l}10 \\
25\end{array}$ \\
\hline $\begin{array}{l}\text { July } \\
\\
24-24 \\
24 \ldots \\
24 \ldots \\
24 \ldots \\
24 \ldots\end{array}$ & $\begin{array}{l}0700-1115 \\
0707 \\
0718 \\
0733 \\
0744\end{array}$ & $\begin{array}{l}0.03 \\
-- \\
-- \\
--\end{array}$ & $\begin{array}{l}-- \\
0.06 \\
0.04 \\
0.06 \\
0.04\end{array}$ & $\begin{array}{l}-- \\
-- \\
-- \\
-\end{array}$ & $\begin{array}{l}23 \\
27 \\
35 \\
22 \\
27 \\
-82-\end{array}$ & $\begin{array}{l}5.4 \\
7.6 \\
6.6 \\
2.7 \\
3.3\end{array}$ & $\begin{array}{l}420,000 \\
300,000 \\
680,000 \\
260,000 \\
280,000\end{array}$ & $\begin{array}{r}160,000 \\
320,000 \\
130,000 \\
110,000 \\
80,000\end{array}$ & $\begin{array}{l}63 \\
65 \\
70 \\
49 \\
45\end{array}$ & $\begin{array}{r}12 \\
57 \\
14 \\
9 \\
7\end{array}$ \\
\hline
\end{tabular}


Table 13.--Nater analyses of the inflow at Alta Vista--Continued

\begin{tabular}{|c|c|c|c|c|c|c|c|c|c|c|}
\hline Date & $\begin{array}{l}\text { Solids, } \\
\text { vola- } \\
\text { tile, } \\
\text { dis- } \\
\text { solved } \\
\text { (mg/L) }\end{array}$ & $\begin{array}{l}\text { Nitro- } \\
\text { gen, } \\
\text { totai } \\
\text { (mg/h } \\
\text { as N) }\end{array}$ & $\begin{array}{c}\text { Nitro- } \\
\text { gen, } \\
\text { No2+NO3, } \\
\text { total } \\
(\mathrm{mg} / \mathrm{L} \\
\text { as N) }\end{array}$ & $\begin{array}{l}\text { Nitro- } \\
\text { gen, am- } \\
\text { monia }+ \\
\text { organic, } \\
\text { total } \\
\text { (mg/L } \\
\text { as N) } \\
\end{array}$ & $\begin{array}{c}\text { Phos- } \\
\text { phorus, } \\
\text { total } \\
\text { (mg/L } \\
\text { as P) }\end{array}$ & $\begin{array}{l}\text { Carbon, } \\
\text { organic, } \\
\text { total } \\
(\mathrm{mg} / \mathrm{L} \\
\text { as C) }\end{array}$ & $\begin{array}{l}\text { Cadmium, } \\
\text { dis- } \\
\text { solved } \\
(\mu \mathrm{g} / \mathrm{L})\end{array}$ & $\begin{array}{l}\text { Iron, } \\
\text { dis- } \\
\text { solved } \\
(\mu \mathrm{g} / \mathrm{L})\end{array}$ & $\begin{array}{c}\text { Lead, } \\
\text { dis- } \\
\text { solved } \\
(\mu \mathrm{g} / \mathrm{L})\end{array}$ & $\begin{array}{l}\text { Zinc, } \\
\text { dis- } \\
\text { solved } \\
(\mu \mathrm{g} / \mathrm{L})\end{array}$ \\
\hline $\begin{array}{r}\text { Sept. } 1982 \\
19-20 \\
19 \ldots \\
19 \ldots \\
19 \ldots \\
19 \ldots\end{array}$ & $\begin{array}{l}14 \\
22 \\
10 \\
12 \\
11\end{array}$ & $\begin{array}{l}1.0 \\
1.5 \\
1.0 \\
0.8 \\
0.8\end{array}$ & $\begin{array}{l}0.20 \\
0.50 \\
0.20 \\
0.10 \\
0.10\end{array}$ & $\begin{array}{l}0.8 \\
1.0 \\
0.8 \\
0.7 \\
0.7\end{array}$ & $\begin{array}{l}0.30 \\
0.63 \\
0.27 \\
0.28 \\
0.37\end{array}$ & $\begin{array}{c}4.6 \\
14 \\
5.2 \\
4.3 \\
4.0\end{array}$ & $\begin{array}{l}<1 \\
<1 \\
<1 \\
<1 \\
<1\end{array}$ & $\begin{array}{l}10 \\
10 \\
20 \\
10 \\
10\end{array}$ & $\begin{array}{r}4 \\
<1 \\
5 \\
3 \\
6\end{array}$ & $\begin{array}{l}10 \\
20 \\
10 \\
10 \\
10\end{array}$ \\
\hline Nov. $02-02$ & 14 & 1.5 & 0.30 & 1.2 & 0.40 & 8.9 & $<1$ & 50 & 2 & 10 \\
\hline $\begin{aligned} \text { Mar. } & 1983 \\
& 15-15 \\
& 30-30\end{aligned}$ & $\begin{array}{l}30 \\
27\end{array}$ & $\begin{array}{l}2.6 \\
2.2\end{array}$ & $\begin{array}{l}0.70 \\
0.70\end{array}$ & $\begin{array}{l}1.9 \\
1.5\end{array}$ & $\begin{array}{l}0.41 \\
0.35\end{array}$ & $\begin{array}{l}15 \\
10\end{array}$ & $\begin{array}{l}<1 \\
<1\end{array}$ & $\begin{array}{l}22 \\
20\end{array}$ & $\begin{array}{r}<1 \\
7\end{array}$ & $\begin{array}{l}22 \\
30\end{array}$ \\
\hline $\begin{array}{l}10-11 \\
10 \ldots \\
10 \ldots \\
10 \ldots \\
10 \ldots\end{array}$ & $\begin{array}{l}20 \\
52 \\
27 \\
18 \\
26\end{array}$ & $\begin{array}{l}2.1 \\
5.4 \\
1.6 \\
1.5 \\
2.4\end{array}$ & $\begin{array}{l}0.60 \\
1.00 \\
0.20 \\
0.30 \\
0.70\end{array}$ & $\begin{array}{l}1.5 \\
4.4 \\
1.4 \\
1.2 \\
1.7\end{array}$ & $\begin{array}{l}0.29 \\
0.78 \\
0.20 \\
0.27 \\
0.28\end{array}$ & $\begin{array}{c}7.1 \\
19 \\
6.2 \\
6.2 \\
8.4\end{array}$ & $\begin{array}{l}<1 \\
<1 \\
<1 \\
<1 \\
<1\end{array}$ & $\begin{array}{l}28 \\
22 \\
14 \\
28 \\
33\end{array}$ & $\begin{array}{l}2 \\
6 \\
0 \\
3 \\
3\end{array}$ & $\begin{array}{l}14 \\
35 \\
15 \\
11 \\
17\end{array}$ \\
\hline June $14-14$ & 12 & 3.5 & 2.20 & 1.3 & 0.30 & 7.3 & $<1$ & 15 & 4 & 29 \\
\hline July $05-06$ & 42 & 3.1 & 0.90 & 2.2 & 1.40 & 20 & $<1$ & 20 & 4 & 20 \\
\hline $\begin{array}{l}\text { Aug. } \\
\begin{array}{l} \\
04-04 \\
04 \ldots \\
04 \ldots \\
04 \ldots \\
04 \ldots\end{array}\end{array}$ & $\begin{array}{l}19 \\
21 \\
22 \\
19 \\
19\end{array}$ & $\begin{array}{l}2.4 \\
3.0 \\
2.6 \\
1.6 \\
1.5\end{array}$ & $\begin{array}{l}0.40 \\
0.80 \\
0.50 \\
0.40 \\
0.40\end{array}$ & $\begin{array}{l}2.0 \\
2.2 \\
2.1 \\
1.2 \\
1.1\end{array}$ & $\begin{array}{l}0.43 \\
0.40 \\
0.43 \\
0.50 \\
0.51\end{array}$ & $\begin{array}{l}9.3 \\
12 \\
11 \\
8.6 \\
8.1\end{array}$ & $\begin{array}{l}<1 \\
<1 \\
<1 \\
<1 \\
<1\end{array}$ & $\begin{array}{r}29 \\
9 \\
14 \\
29 \\
38\end{array}$ & $\begin{array}{r}<1 \\
<1 \\
<1 \\
1 \\
<1\end{array}$ & $\begin{array}{l}13 \\
14 \\
14 \\
11 \\
10\end{array}$ \\
\hline Sept. $_{18-18}$ & 31 & 1.8 & 0.40 & 1.4 & 0.75 & 12 & $<1$ & 40 & 3 & 20 \\
\hline $\begin{array}{ll}\text { 0ct. } & \\
& 09-09 \\
& 09 . \ldots \\
& 09 . . \\
& 09 . \ldots \\
& 09 . \ldots\end{array}$ & $\begin{array}{r}7 \\
11 \\
7 \\
6 \\
4\end{array}$ & $\begin{array}{l}1.5 \\
1.9 \\
1.6 \\
1.4 \\
1.3\end{array}$ & $\begin{array}{l}0.50 \\
0.70 \\
0.60 \\
0.50 \\
0.40\end{array}$ & $\begin{array}{l}1.0 \\
1.2 \\
1.0 \\
0.9 \\
0.9\end{array}$ & $\begin{array}{l}0.32 \\
0.38 \\
0.37 \\
0.28 \\
0.27\end{array}$ & $\begin{array}{l}6.9 \\
3.4 \\
7.4 \\
5.3 \\
4.6\end{array}$ & $\begin{array}{l}<1 \\
<1 \\
<1 \\
<1 \\
<1\end{array}$ & $\begin{array}{l}11 \\
12 \\
18 \\
10 \\
13\end{array}$ & $\begin{array}{l}2 \\
2 \\
2 \\
2 \\
2\end{array}$ & $\begin{array}{r}12 \\
18 \\
13 \\
9 \\
10\end{array}$ \\
\hline Nov. $22-23$ & 20 & 4.8 & 1.30 & 3.5 & 0.87 & 17 & $<1$ & 38 & 5 & 27 \\
\hline Dec. $03-03$ & 11 & 0.7 & 0.20 & 0.5 & 0.29 & 6.0 & $<1$ & 50 & 2 & 10 \\
\hline Fed. $\begin{array}{l}1984 \\
26-25\end{array}$ & 15 & 2.1 & 0.70 & 1.4 & 0.34 & 12 & $<1$ & 70 & 6 & 13 \\
\hline $\begin{array}{r}\text { Mar. } \\
04-04 \\
12-12\end{array}$ & $\begin{array}{l}14 \\
18\end{array}$ & $\begin{array}{l}2.3 \\
1.7\end{array}$ & $\begin{array}{l}0.80 \\
0.60\end{array}$ & $\begin{array}{l}1.5 \\
1.1\end{array}$ & $\begin{array}{l}0.25 \\
0.20\end{array}$ & $\begin{array}{l}9.1 \\
8.1\end{array}$ & $\begin{array}{l}<1 \\
<1\end{array}$ & $\begin{array}{l}34 \\
27\end{array}$ & $\begin{array}{l}<1 \\
<1\end{array}$ & $\begin{array}{l}11 \\
22\end{array}$ \\
\hline $18-18$ & 28 & 4.1 & 1.40 & 2.7 & 0.56 & 11 & $<1$ & 29 & 5 & 27 \\
\hline $\begin{array}{l}\text { June } \\
\begin{array}{l}05-05 \\
12-12\end{array}\end{array}$ & $\begin{array}{l}30 \\
21\end{array}$ & $\begin{array}{l}2.1 \\
2.0\end{array}$ & $\begin{array}{l}0.70 \\
0.50\end{array}$ & $\begin{array}{l}1.4 \\
1.5\end{array}$ & $\begin{array}{l}0.50 \\
0.32\end{array}$ & $\begin{array}{l}12 \\
11\end{array}$ & $\begin{array}{l}1 \\
<1\end{array}$ & $\begin{array}{l}31 \\
25\end{array}$ & $\begin{array}{l}<1 \\
<1\end{array}$ & $\begin{array}{l}22 \\
25\end{array}$ \\
\hline $\begin{aligned} \text { July } & \\
& 24-24 \\
& 24 \ldots \\
& 24 \ldots \\
& 24 \ldots \\
& 24 \ldots\end{aligned}$ & $\begin{array}{l}20 \\
23 \\
24 \\
17 \\
18\end{array}$ & $\begin{array}{l}1.8 \\
3.0 \\
2.4 \\
1.5 \\
1.3\end{array}$ & $\begin{array}{l}0.80 \\
1.40 \\
1.00 \\
0.60 \\
0.50\end{array}$ & $\begin{array}{l}1.0 \\
1.6 \\
1.4 \\
0.9 \\
0.8\end{array}$ & $\begin{array}{l}0.37 \\
0.29 \\
0.39 \\
0.30 \\
0.30\end{array}$ & $\begin{array}{l}10 \\
12 \\
12 \\
8.3 \\
0.8\end{array}$ & $\begin{array}{l}<1 \\
<1 \\
<1 \\
<1 \\
<1\end{array}$ & $\begin{array}{l}45 \\
30 \\
20 \\
20 \\
10\end{array}$ & $\begin{array}{l}5 \\
3 \\
2 \\
4 \\
2\end{array}$ & $\begin{array}{l}20 \\
20 \\
20 \\
20 \\
20\end{array}$ \\
\hline
\end{tabular}


Table 14.-- Water analyses of the outflow at Alta Vista

$\left[\mathrm{ft}^{3} / \mathrm{s}\right.$, cubic foot per second; $\mu \mathrm{s} / \mathrm{cm}$, microsiemens per centineter at 25 degrees Celsius; mg/L, milligran per $1 \mathrm{iter}$; cols./100 mL, colonies per 100 milliliters; K, non-ideal colony count; $1 \mathrm{~g} / \mathrm{L}$, microgram per $7 \mathrm{iter}]$

08154680 ilayfield Creek at Steck Avenue at Austin, Texas

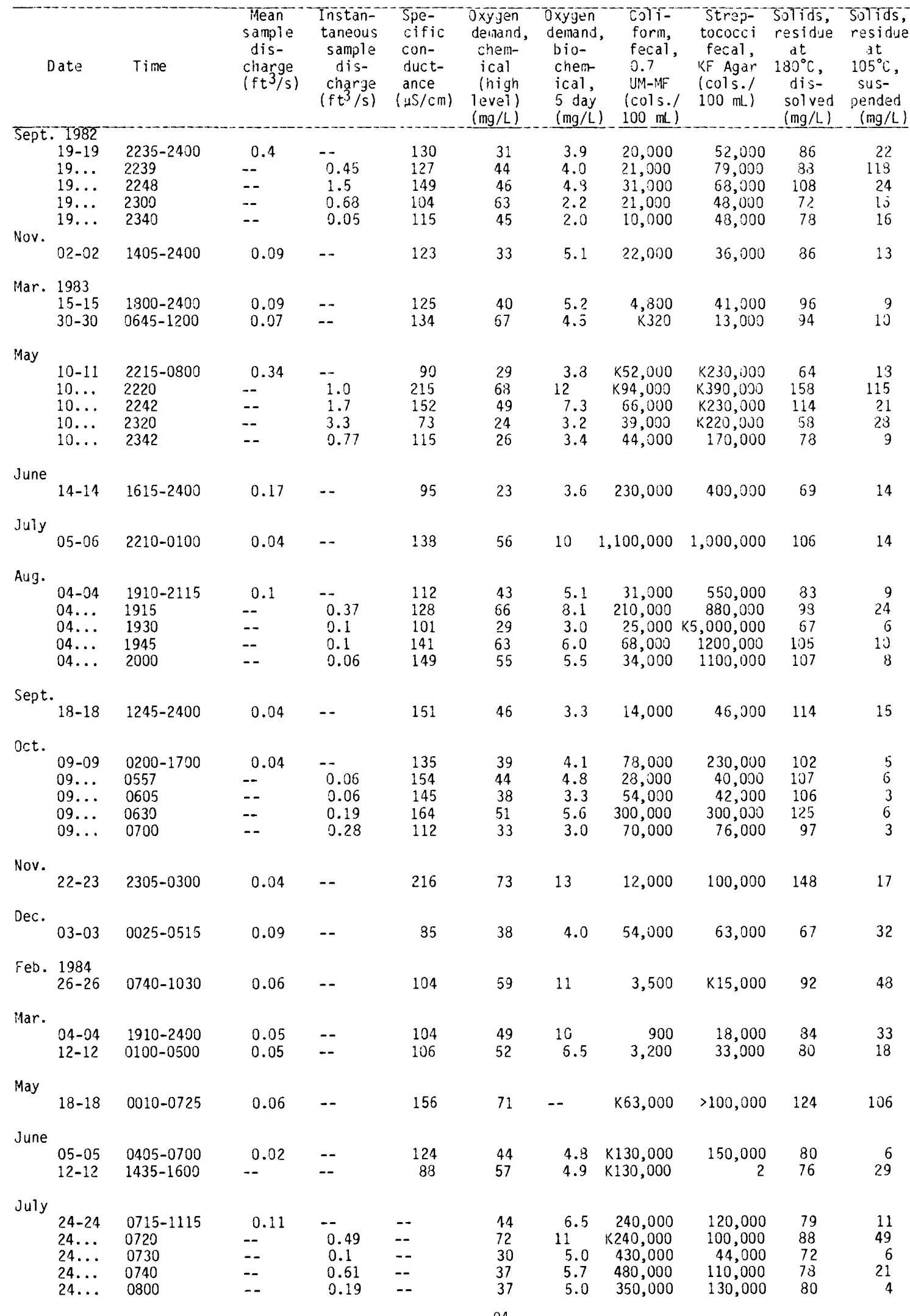


Table 14.--Nater analyses of the outlflow at Alta Vista--Continued

\begin{tabular}{|c|c|c|c|c|c|c|c|c|c|c|}
\hline Date & $\begin{array}{l}\text { Solids, } \\
\text { vola- } \\
\text { tile, } \\
\text { dis- } \\
\text { solved } \\
(\mathrm{mg} / \mathrm{L})\end{array}$ & $\begin{array}{l}\text { Nitro- } \\
\text { gen, } \\
\text { total } \\
\text { (mg/L } \\
\text { as N) }\end{array}$ & $\begin{array}{l}\text { Nitro- } \\
\text { gen, } \\
\mathrm{NO}_{2+\mathrm{NO}} \text {, } \\
\text { total } \\
\text { (mg/L } \\
\text { as N) }\end{array}$ & $\begin{array}{l}\text { Nitro- } \\
\text { gen, am- } \\
\text { monia }+ \\
\text { organic, } \\
\text { total } \\
(\mathrm{mg} / \mathrm{L} \\
\text { as } \mathrm{N}) \\
\end{array}$ & $\begin{array}{l}\text { Phos- } \\
\text { phorus, } \\
\text { total } \\
(\mathrm{mg} / \mathrm{L} \\
\text { as } \mathrm{P})\end{array}$ & $\begin{array}{l}\text { Carbon, } \\
\text { organic, } \\
\text { total } \\
\text { (mg/L } \\
\text { as C) }\end{array}$ & $\begin{array}{l}\text { Cadmi um, } \\
\text { dis- } \\
\text { solved } \\
(\mu \mathrm{g} / \mathrm{L})\end{array}$ & $\begin{array}{l}\text { Iron, } \\
\text { dis- } \\
\text { solved } \\
(\mu \mathrm{g} / \mathrm{L})\end{array}$ & $\begin{array}{l}\text { Lead, } \\
\text { dis- } \\
\text { solved } \\
(\mu \mathrm{g} / \mathrm{L})\end{array}$ & $\begin{array}{l}\text { Zinc, } \\
\text { dis- } \\
\text { solved } \\
(\mu \mathrm{g} / \mathrm{L})\end{array}$ \\
\hline $\begin{array}{r}\text { Sept. } 1982 \\
19-19 \\
19 \ldots \\
19 \ldots \\
19 \ldots \\
19 \ldots\end{array}$ & $\begin{array}{l}22 \\
26 \\
33 \\
19 \\
18\end{array}$ & $\begin{array}{l}2.1 \\
1.8 \\
2.8 \\
1.4 \\
1.6\end{array}$ & $\begin{array}{l}0.50 \\
0.50 \\
0.70 \\
0.40 \\
0.30\end{array}$ & $\begin{array}{l}1.6 \\
1.3 \\
2.1 \\
1.0 \\
1.3\end{array}$ & $\begin{array}{l}1.10 \\
0.75 \\
1.30 \\
1.00 \\
1.10\end{array}$ & $\begin{array}{c}11 \\
9.5 \\
14 \\
7.9 \\
6.5\end{array}$ & $\begin{array}{l}<1 \\
<1 \\
<1 \\
<1 \\
<1\end{array}$ & $\begin{array}{l}40 \\
73 \\
40 \\
40 \\
40\end{array}$ & $\begin{array}{l}<1 \\
<1 \\
<1 \\
<1 \\
1\end{array}$ & $\begin{array}{l}10 \\
14 \\
20 \\
10 \\
10\end{array}$ \\
\hline Nov. $02-02$ & 20 & 1.6 & 0.30 & 1.3 & 0.84 & 12 & $<1$ & 50 & 1 & 10 \\
\hline Mar. $\begin{aligned} 1983 \\
15-15 \\
30-30\end{aligned}$ & $\begin{array}{l}34 \\
30\end{array}$ & $\begin{array}{l}2.0 \\
1.8\end{array}$ & $\begin{array}{l}0.50 \\
0.50\end{array}$ & $\begin{array}{l}1.5 \\
1.3\end{array}$ & $\begin{array}{l}0.70 \\
0.53\end{array}$ & $\begin{array}{c}14 \\
8.7\end{array}$ & $\begin{array}{l}<1 \\
<1\end{array}$ & $\begin{array}{l}58 \\
30\end{array}$ & $\begin{array}{r}<1 \\
4\end{array}$ & $\begin{array}{l}29 \\
20\end{array}$ \\
\hline $\begin{array}{l}10-11 \\
10 \ldots \\
10 \ldots \\
10 \ldots \\
10 \ldots\end{array}$ & $\begin{array}{l}22 \\
44 \\
34 \\
20 \\
23\end{array}$ & $\begin{array}{ll}1 & 2.9 \\
1 & 1 \\
& 4.8 \\
& 2.6 \\
& 2.7\end{array}$ & $\begin{array}{l}0.70 \\
2.40 \\
1.50 \\
0.50 \\
0.80\end{array}$ & $\begin{array}{l}2.2 \\
8.4 \\
3.3 \\
2.1 \\
1.9\end{array}$ & $\begin{array}{l}0.63 \\
1.80 \\
1.00 \\
0.57 \\
0.59\end{array}$ & $\begin{array}{l}7.9 \\
19 \\
16 \\
7.4 \\
7.9\end{array}$ & $\begin{array}{l}<1 \\
<1 \\
<1 \\
<1 \\
<1\end{array}$ & $\begin{array}{l}56 \\
30 \\
44 \\
30 \\
36\end{array}$ & $\begin{array}{l}5 \\
6 \\
7 \\
2 \\
2\end{array}$ & $\begin{array}{r}15 \\
20 \\
18 \\
20 \\
9\end{array}$ \\
\hline June $14-14$ & 22 & 1.8 & 0.80 & 1.0 & 0.52 & 6.4 & $<1$ & 28 & 3 & 15 \\
\hline $\begin{array}{l}\text { July } \\
05-05\end{array}$ & 30 & 2.3 & 0.80 & 2.0 & 1.30 & 14 & $<1$ & 30 & 2 & 20 \\
\hline 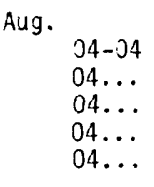 & $\begin{array}{l}23 \\
24 \\
15 \\
28 \\
26\end{array}$ & $\begin{array}{l}2.0 \\
2.8 \\
1.5 \\
2.3 \\
2.1\end{array}$ & $\begin{array}{l}0.60 \\
0.70 \\
0.50 \\
0.70 \\
0.50\end{array}$ & $\begin{array}{l}1.4 \\
2.1 \\
1.0 \\
1.6 \\
1.6\end{array}$ & $\begin{array}{l}0.98 \\
1.20 \\
0.55 \\
1.70 \\
1.50\end{array}$ & $\begin{array}{l}12 \\
17 \\
6.2 \\
18 \\
16\end{array}$ & $\begin{array}{l}<1 \\
<1 \\
<1 \\
<1 \\
<1\end{array}$ & $\begin{array}{l}24 \\
15 \\
21 \\
32 \\
31\end{array}$ & $\begin{array}{l}<1 \\
1 \\
<1 \\
<1 \\
<1\end{array}$ & $\begin{array}{l}11 \\
18 \\
10 \\
15 \\
21\end{array}$ \\
\hline${ }_{18-18}$ & 32 & 1.8 & 0.30 & 1.5 & 1.10 & 12 & $<1$ & 30 & 2 & 20 \\
\hline $\begin{array}{ll}\text { Oct. } & \\
& 09-09 \\
& 09 \ldots \\
09 \ldots \\
09 \ldots \\
09 \ldots\end{array}$ & $\begin{array}{l}23 \\
24 \\
28 \\
38 \\
39\end{array}$ & $\begin{array}{l}2.2 \\
2.7 \\
2.3 \\
2.9 \\
2.5\end{array}$ & $\begin{array}{l}0.80 \\
0.80 \\
0.90 \\
0.80 \\
0.50\end{array}$ & $\begin{array}{l}1.4 \\
1.9 \\
1.4 \\
2.1 \\
2.0\end{array}$ & $\begin{array}{l}0.90 \\
0.80 \\
0.66 \\
1.70 \\
0.77\end{array}$ & $\begin{array}{c}11 \\
11 \\
8.4 \\
13 \\
7.3\end{array}$ & $\begin{array}{l}<1 \\
<1 \\
<1 \\
<1 \\
<1\end{array}$ & $\begin{array}{l}18 \\
13 \\
17 \\
21 \\
21\end{array}$ & $\begin{array}{l}3 \\
3 \\
4 \\
4 \\
2\end{array}$ & $\begin{array}{r}3 \\
10 \\
7 \\
3 \\
4\end{array}$ \\
\hline Nov. $22-23$ & 45 & 6.2 & 2.20 & 4.0 & 1.90 & 21 & $<1$ & 36 & 4 & 17 \\
\hline Dec. $03-03$ & 13 & 1.0 & 0.30 & 0.7 & 0.78 & 7.6 & $<1$ & 25 & 2 & 1.4 \\
\hline Feb. $\begin{array}{l}1984 \\
26-25\end{array}$ & 24 & 3.5 & 1.10 & 2.4 & 0.74 & 15 & $<1$ & 43 & 5 & 23 \\
\hline $\begin{array}{r}\text { Mar. } \\
\quad 4-04 \\
12-12\end{array}$ & $\begin{array}{l}24 \\
25\end{array}$ & $\begin{array}{l}2.6 \\
2.5\end{array}$ & $\begin{array}{l}1.00 \\
0.90\end{array}$ & $\begin{array}{l}1.6 \\
1.6\end{array}$ & $\begin{array}{l}0.65 \\
0.54\end{array}$ & $12^{9.8}$ & $\begin{array}{l}<1 \\
<1\end{array}$ & $\begin{array}{l}46 \\
47\end{array}$ & $\begin{array}{l}<1 \\
?\end{array}$ & $\begin{array}{l}16 \\
14\end{array}$ \\
\hline $18-18$ & 42 & 4.6 & 1.90 & 2.7 & 0.86 & 21 & $<1$ & 29 & 3 & 25 \\
\hline $\begin{array}{l}\text { June } \\
\begin{array}{l}05-05 \\
12-12\end{array}\end{array}$ & $\begin{array}{l}25 \\
28\end{array}$ & $\begin{array}{l}2.2 \\
2.0\end{array}$ & $\begin{array}{l}0.70 \\
0.50\end{array}$ & $\begin{array}{l}1.5 \\
1.5\end{array}$ & $\begin{array}{l}0.63 \\
0.59\end{array}$ & $13^{9.1}$ & $\begin{array}{l}<1 \\
<1\end{array}$ & $\begin{array}{l}21 \\
13\end{array}$ & $\begin{array}{l}2 \\
2\end{array}$ & $\begin{array}{r}<10 \\
18\end{array}$ \\
\hline $\begin{aligned} & \text { July } \\
& \\
& \\
& \\
& 24-24 \\
& 24 \ldots \\
& 24 \ldots \\
& 24 \ldots\end{aligned}$ & $\begin{array}{l}28 \\
29 \\
24 \\
25 \\
26\end{array}$ & $\begin{array}{l}2.2 \\
3.1 \\
2.0 \\
2.2 \\
2.1\end{array}$ & $\begin{array}{l}1.00 \\
1.40 \\
1.00 \\
0.90 \\
1.00\end{array}$ & $\begin{array}{l}1.2 \\
1.7 \\
1.0 \\
1.3 \\
1.1\end{array}$ & $\begin{array}{l}0.59 \\
0.71 \\
0.47 \\
0.66 \\
0.82\end{array}$ & $\begin{array}{l}14 \\
16 \\
3.4 \\
12 \\
11\end{array}$ & $\begin{array}{l}<1 \\
<1 \\
<1 \\
<1 \\
<1\end{array}$ & $\begin{array}{l}30 \\
40 \\
40 \\
40 \\
30\end{array}$ & $\begin{array}{l}3 \\
4 \\
4 \\
3 \\
3\end{array}$ & $\begin{array}{l}20 \\
10 \\
10 \\
10 \\
10\end{array}$ \\
\hline
\end{tabular}


(fig. 43) were larger at the inflow station for four of the five storms analyzed. Measured peak fecal-streptococci densities were larger in the outflow than in the inflow station for three of the five storms analyzed (fig. 44). Measured peak concentrations of BOD (fig. 45) in the outflow exceed measured peak concentrations in the inflow station for three of the five storms analyzed. Measured peak concentrations of suspended solids (fig. 46), total ammonia plus organic nitrogen (fig. 47), total nitrite plus nitrate nitrogen (fig. 48), total nitrogen (fig. 49), and dissolved iron (fig. 50) in the outflow were 1 arger than or equal to those in the inflow stations for all storms except the August 4, 1983, storm and with the exception of the July 24, 1984, storm for suspended solids. Measured peak concentrations of dissolved solids (fig. 51) and total phosphorus (tables 13 and 14) in the outflow exceeded measured peak concentrations in the inflow station for all five storms.

These data indicate that with the exception of fecal coliform, measured peak concentrations or densities of the analyzed water-quality constituents are not being reduced at Alta Vista. Although the authors acknowledge errors in measurement of discharge at the outflow station, the consistently 1 arger measured peak concentrations at the outflow station strongly indicate that concentrations of most water-quality constituents are not reduced by the grass swales and small detention area.

\section{SUMMARY AND CONCLUSIONS}

Rainfall for the storms analyzed at the Barton Creek Square Shopping Center ranged from 0.14 to $2.88 \mathrm{in}$. The rainfall rate for the September 7 , 1983, storm exceeded the 100-year return interval for the 5- and 10-minute duration and was equal to the 50-year return interval for the 15-minute duration. Peak discharge at the inflow station was closely related to the maximum rainfall intensity during a 5-minute interval and occurred about 10 minutes after the maximum intensity. The pipe size of the storm drainage system appears to limit the peak inflow to about $185 \mathrm{ft}^{3} / \mathrm{s}$. Outflow from the pond completely flowed through the filter system for small- to moderate-size storms whereas excess overflowed into a drop outlet during three 1 arge storms. If the storm was contained by the pond, peak outflows generally were less than $3.1 \mathrm{ft}^{3} / \mathrm{s}$ and meanoutflow rate appeared to decrease during the study as the filter became clogged. Moderate increases in peak outflows were noted after cleaning the filter, but the original filtering capacity was not restored. The yield (ratio of runoffto rainfall) of the basin at Barton Creek Square Shopping Center ranged from 0.56 to 1.22 and averaged 0.85 . The variation of yields attributed to gaging errors and 1 arge variability of areal rainfall. Whereas low runoff ratios of several of the storms with large rainfall intensities were caused by water that overflowed the shopping center drainage basin boundaries. The runoffrainfall ratio at the outlet ranged from 0.20 to 0.59 and averaged 0.36 . $A$ water budget of the detention pond indicates that unexplained losses range from 0 to 49 percent and average 20 percent.

Discharge-weighted concentrations or densities of selected water-quality constituents, calculated for the outflow and total inflow to the Barton Creek Square Shopping Center Pond 1, were used to evaluate the effectiveness of the filter in removing contaminants. At Pond 1, discharge-weighted concentrations of most chemical constituents and densities of fecal-coliform and fecal-strep- 

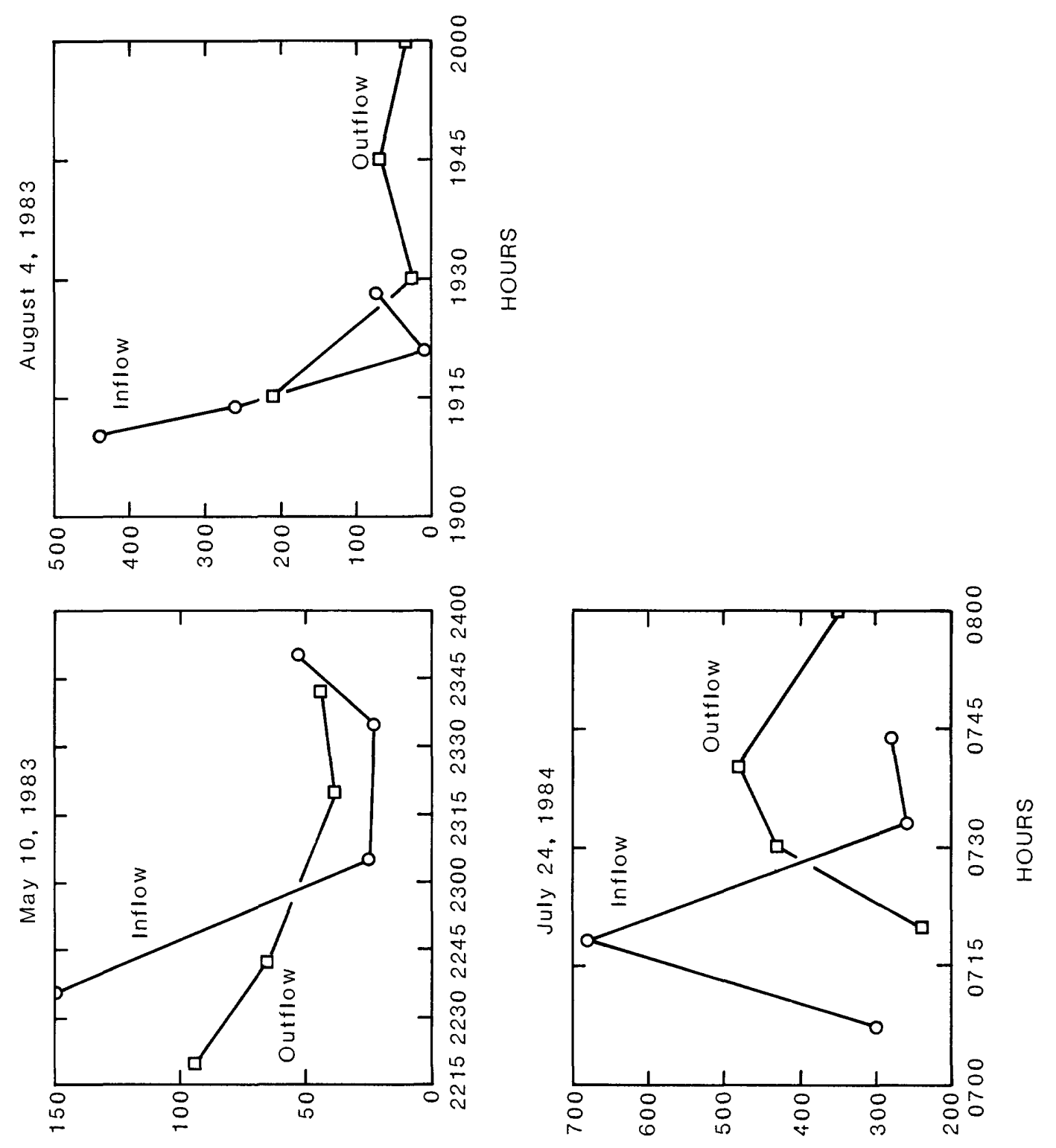

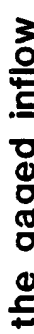
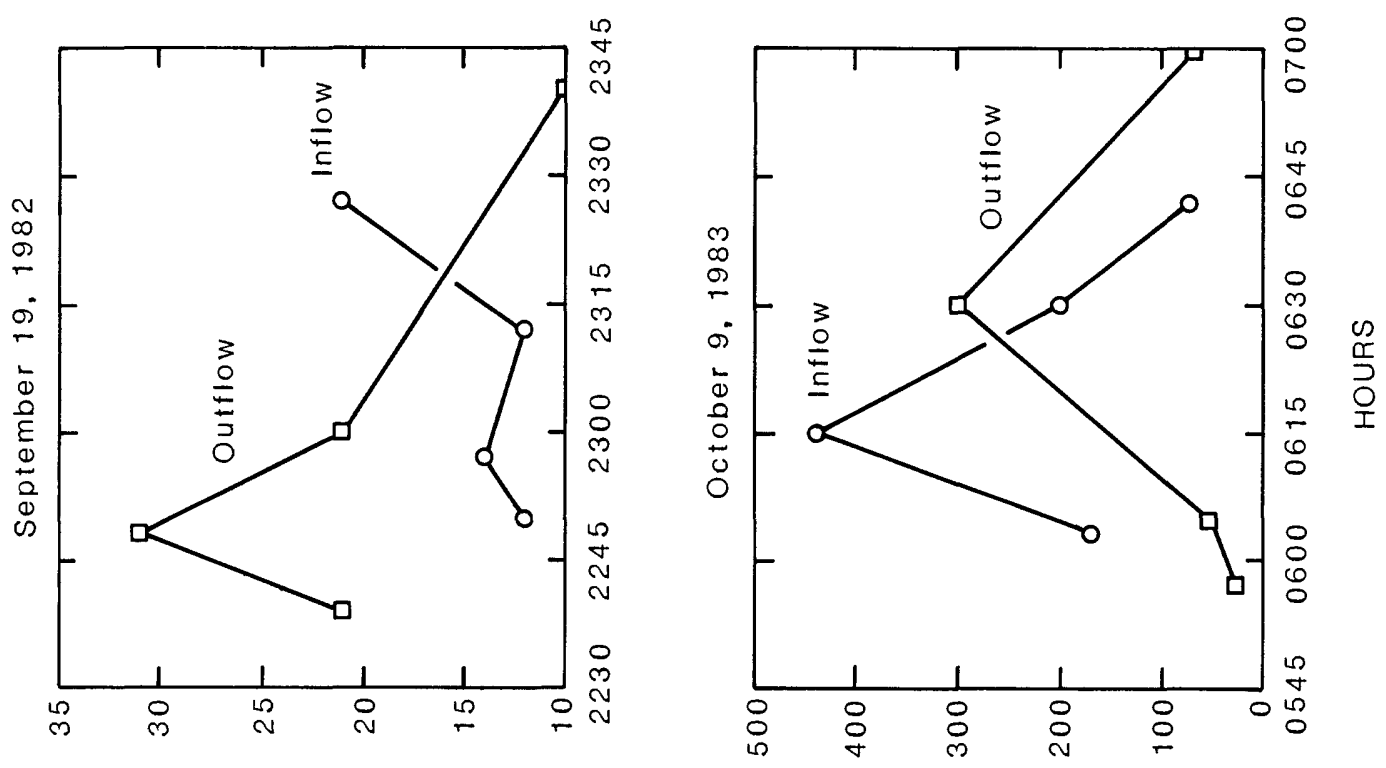

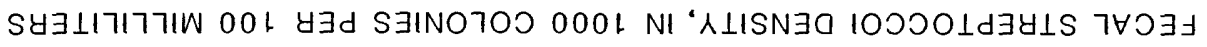



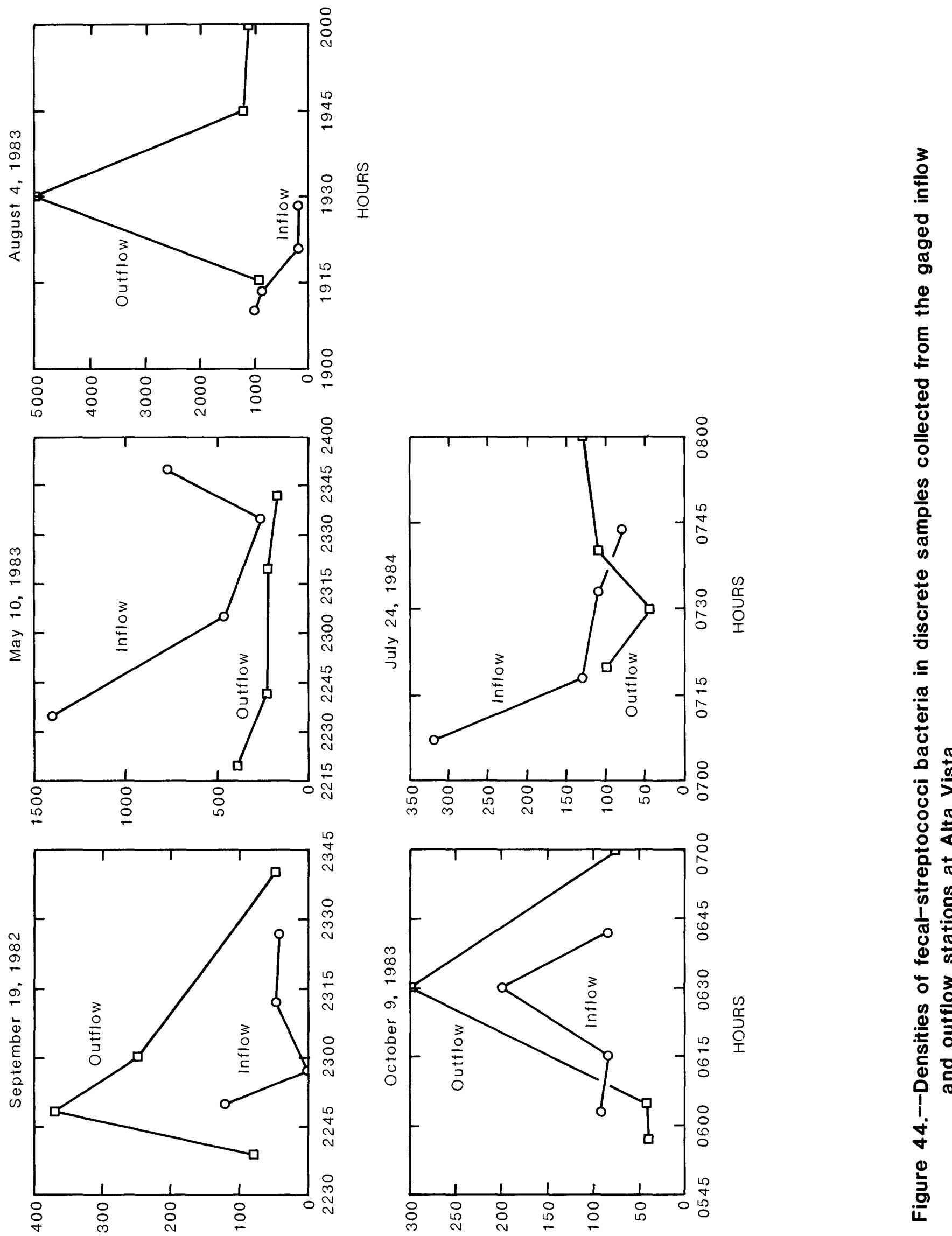

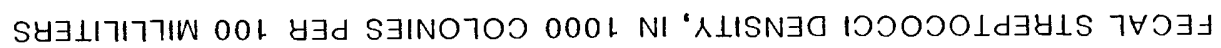



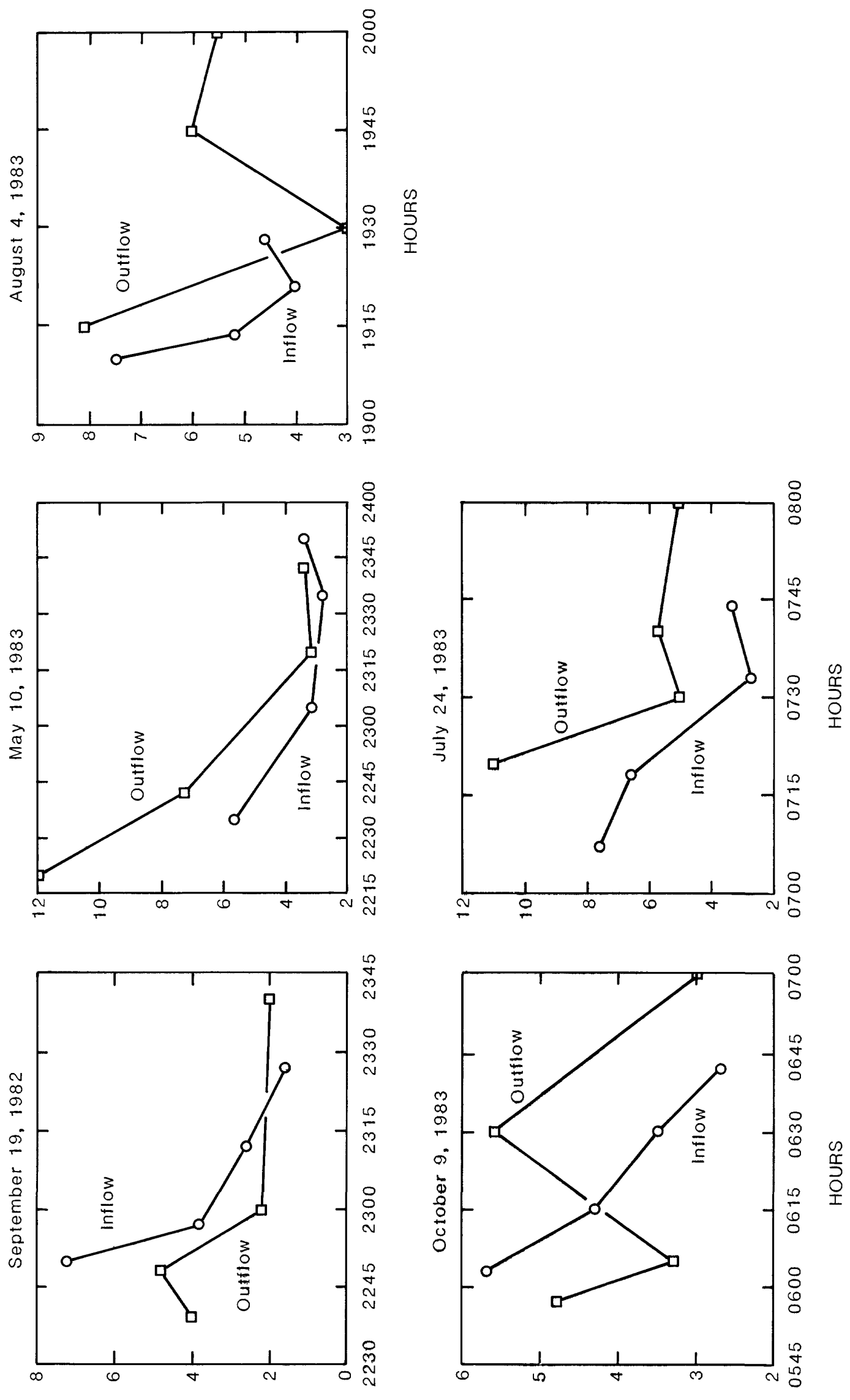

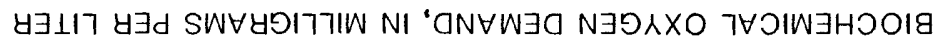



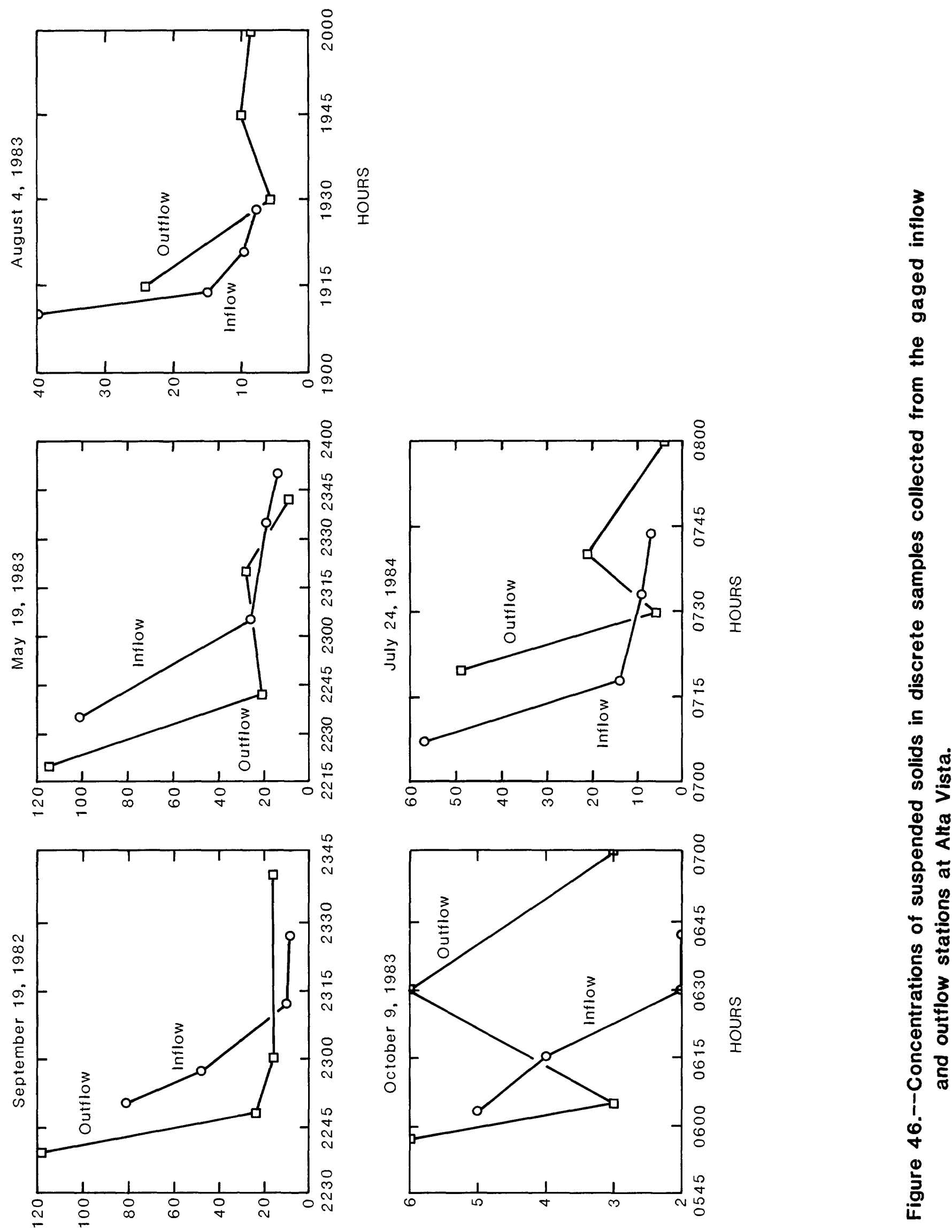

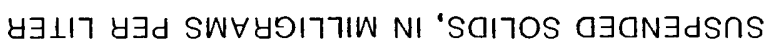




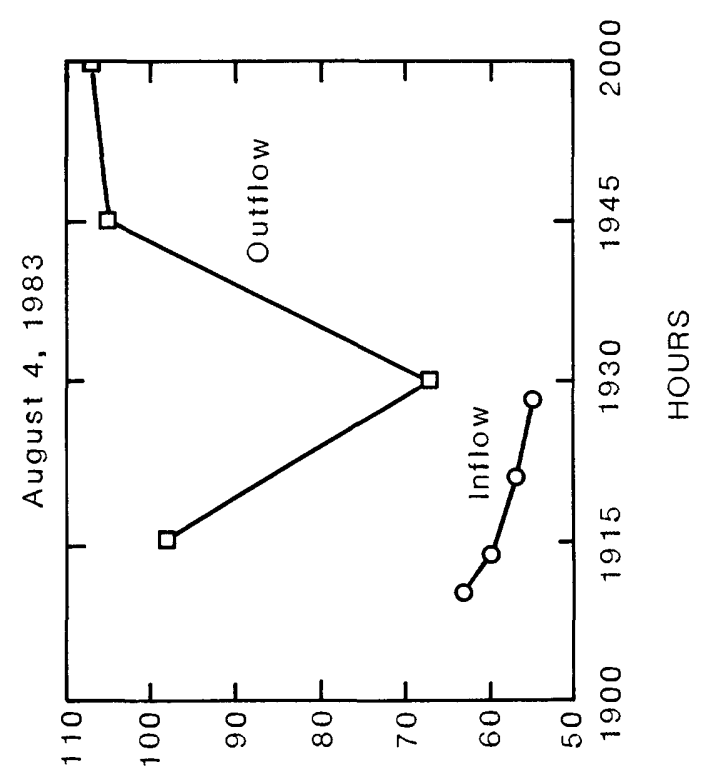

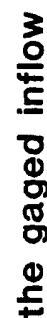

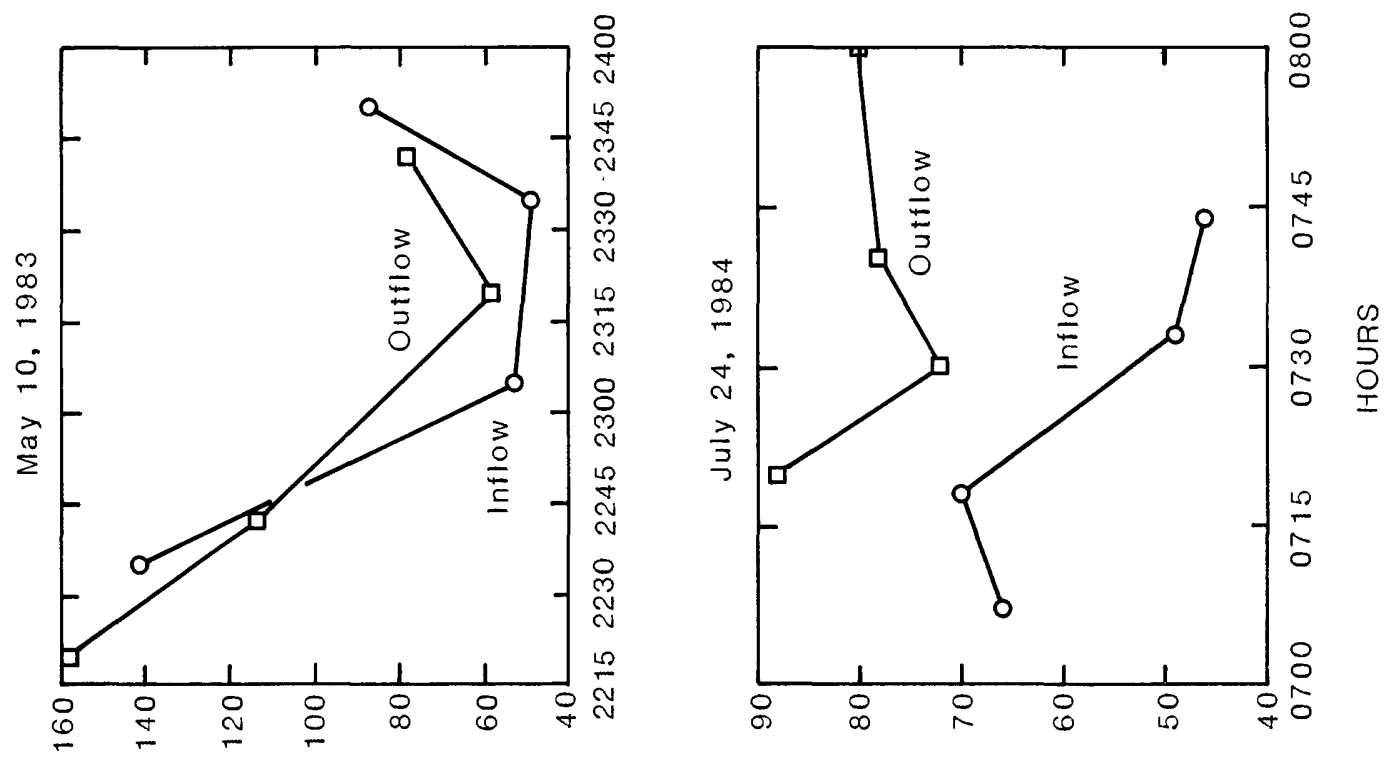

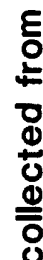

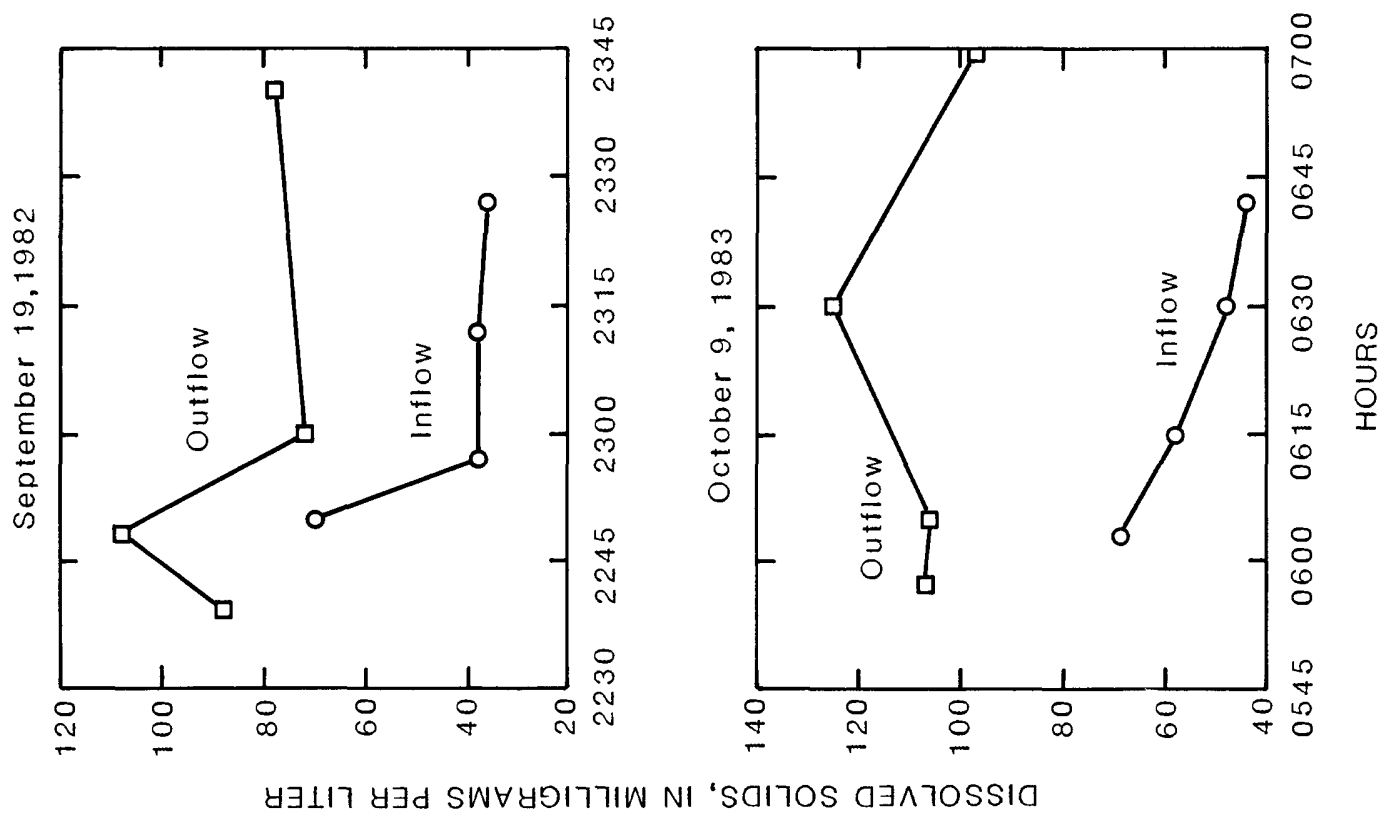

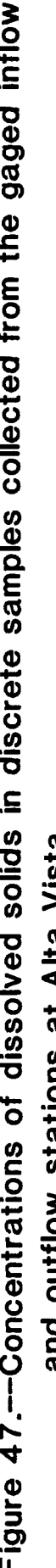



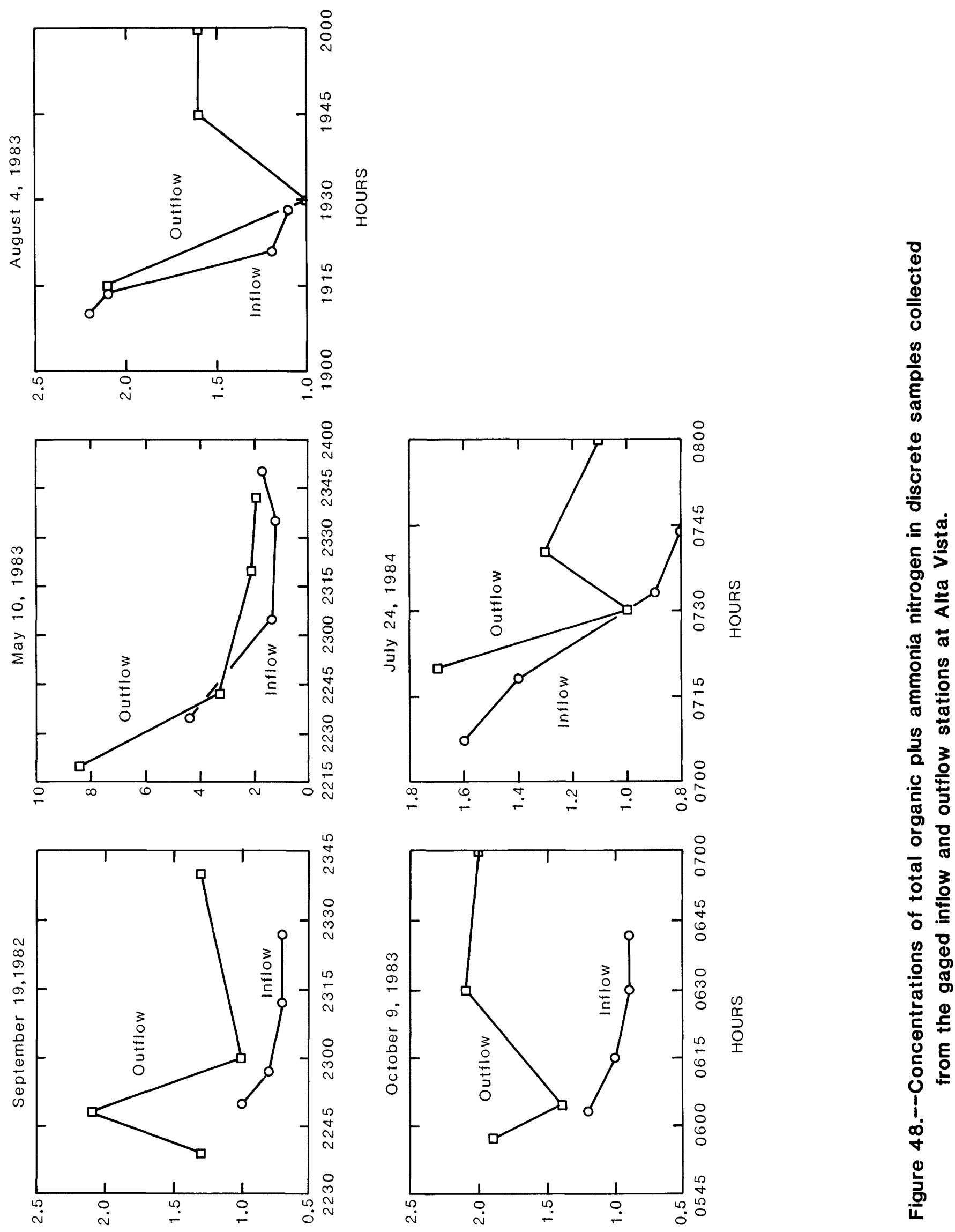

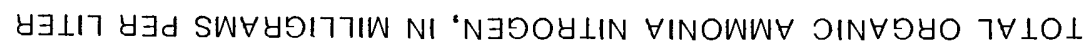



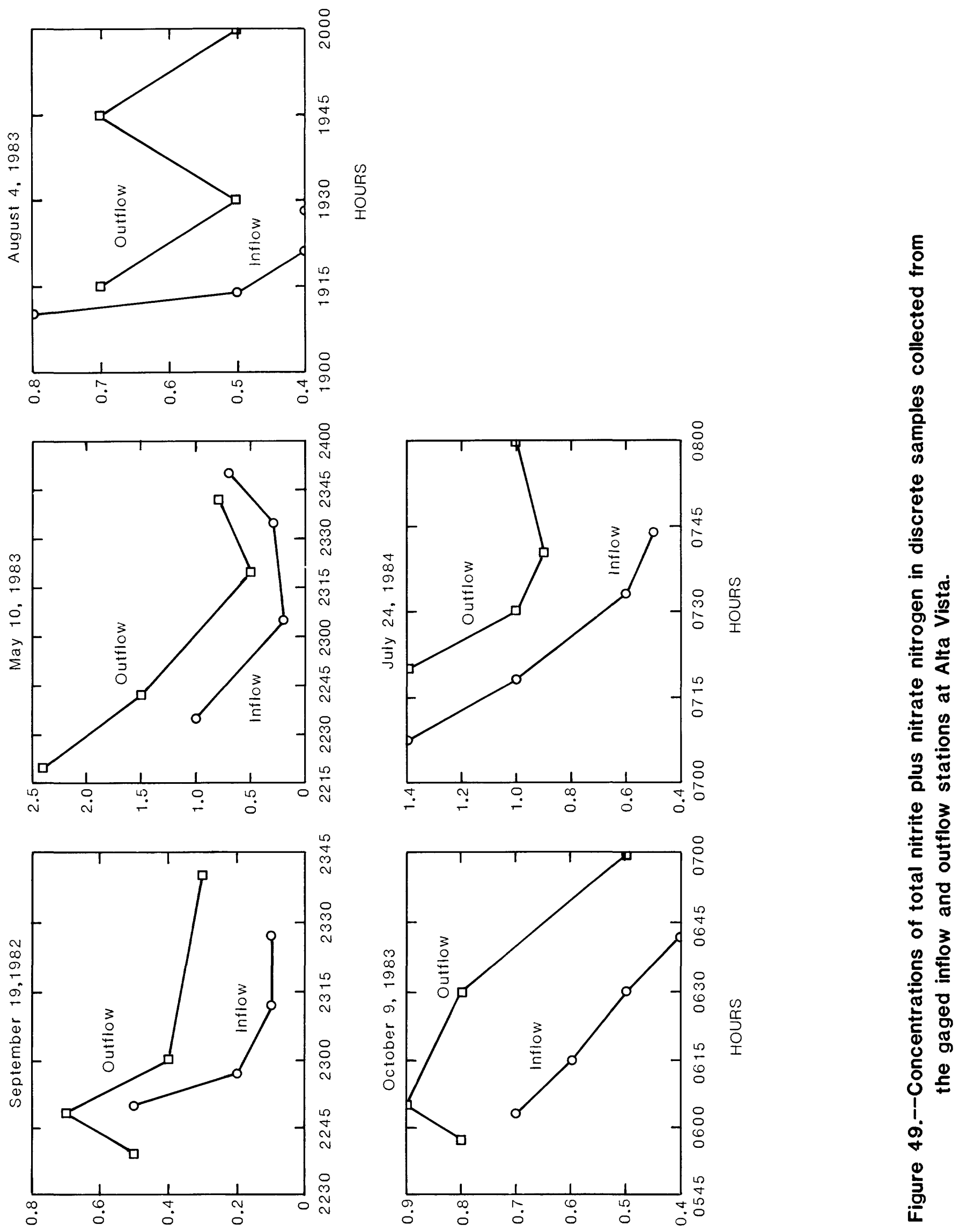

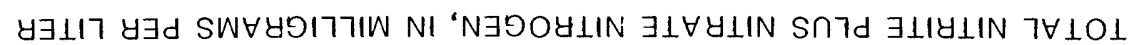



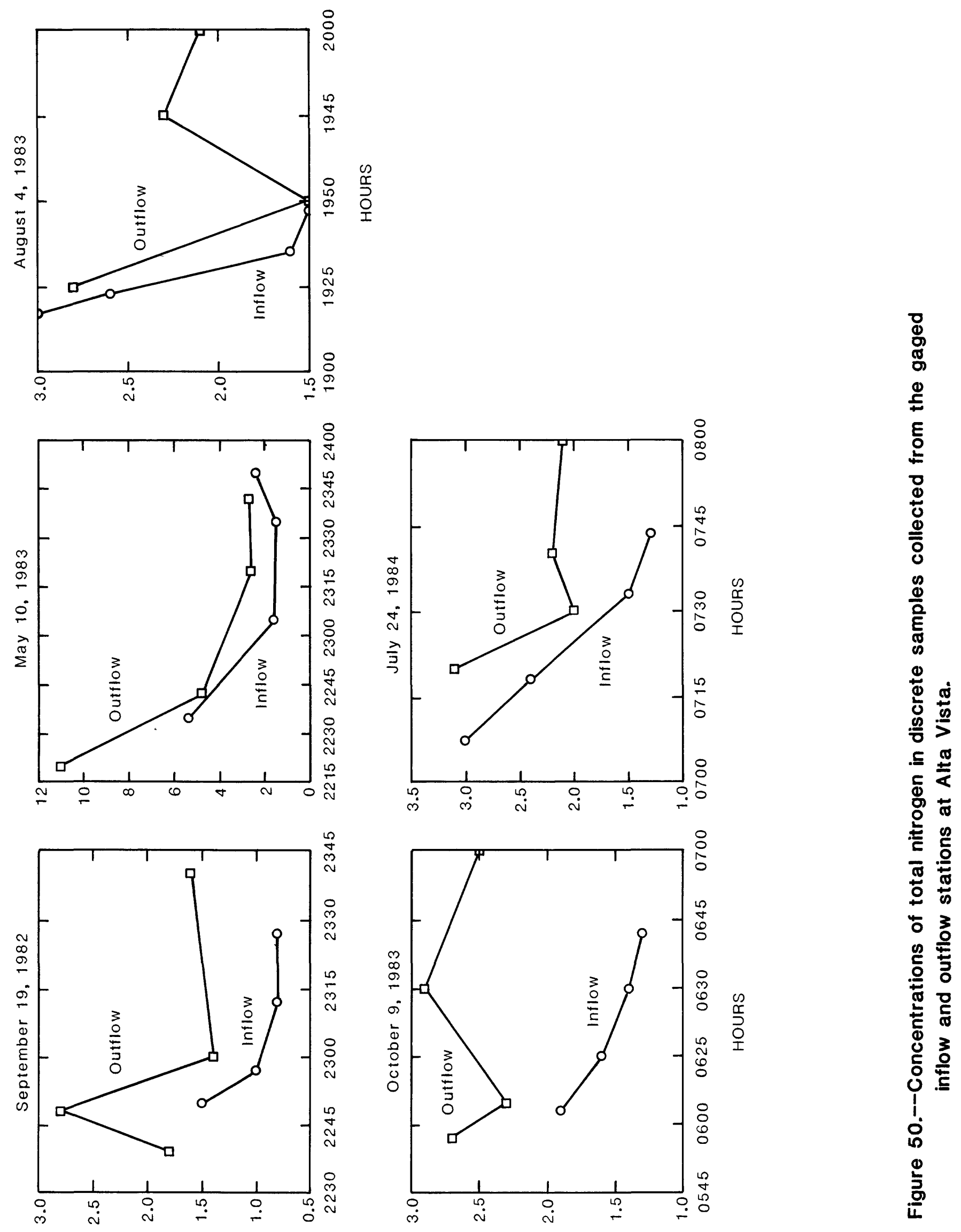

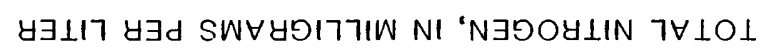



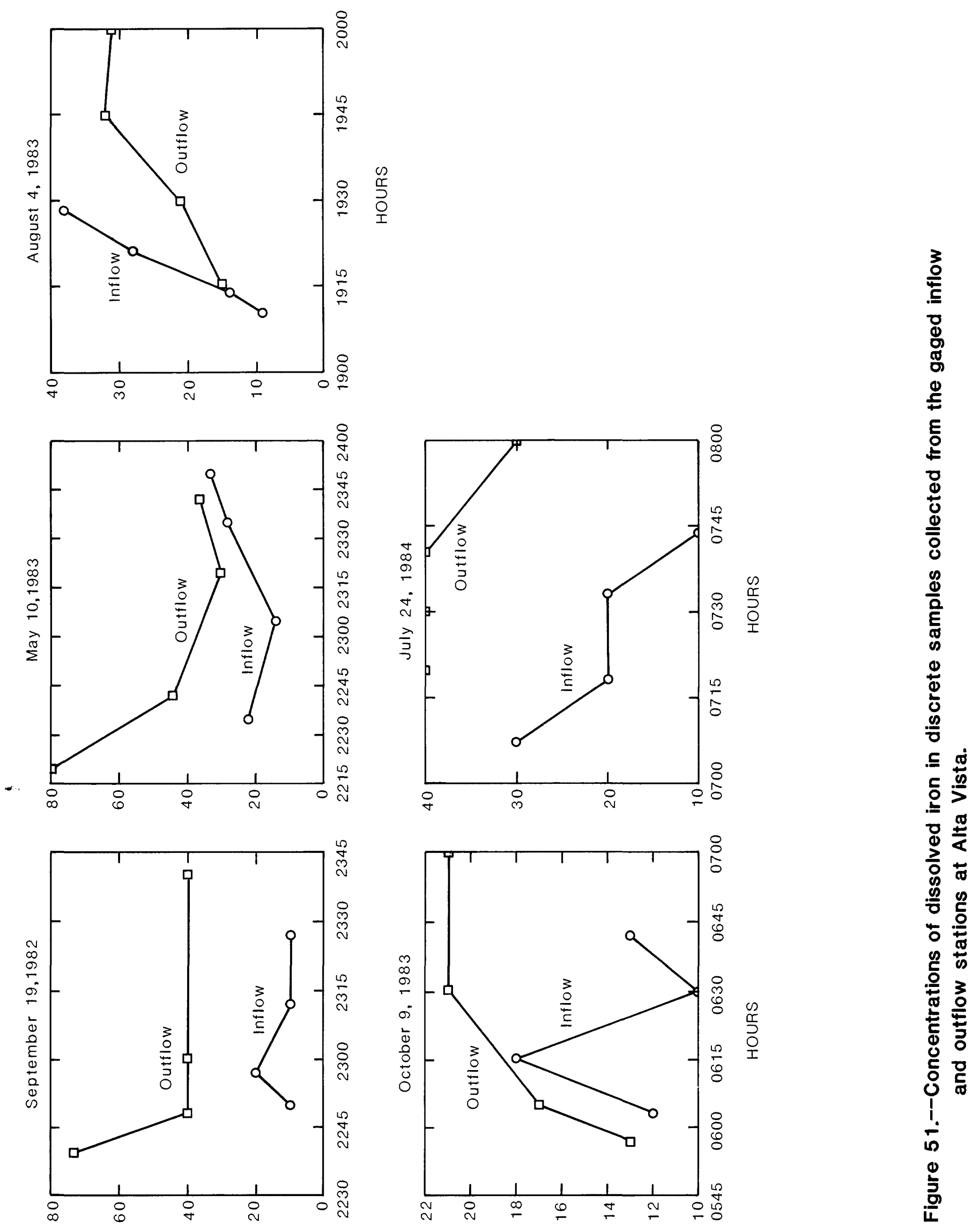

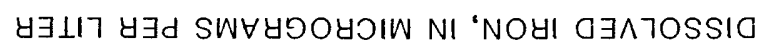


tococci bacteria generally were larger in inflow than in outflow. Dischargeweighted densities of fecal streptococci in the inflow ranged from 5,000 to 220,000 cols./100 mL and exceeded 100,000 cols./100 mL on four occasions. Discharge-weighted densities in outflow ranged from 1,300 to $100,000 \mathrm{cols} . / 100$ $\mathrm{mL}$.

Discharge-weighted concentrations of biochemical oxygen demand and chemical oxygen demand were substantially larger in the inflow than in the outflow. Discharge-weighted biochemical oxygen demand concentrations ranged from 3.3 to $82 \mathrm{mg} / \mathrm{L}$ in the inflow and from 1.1 to $35 \mathrm{mg} / \mathrm{L}$ in the outflow. Dischargeweighted concentrations of chemical oxygen demand ranged from 31 to $760 \mathrm{mg} / \mathrm{L}$ in the inflow and from 19 to $210 \mathrm{mg} / \mathrm{L}$ in the outflow.

Discharge-weighted concentrations of suspended solids varied greatly throughout the study period because of varying amounts of rainfall and varying amounts of vegetated cover in the drainage area around the mall. Except for those storms where inflow overflowed into the drop outlet, discharge-weighted concentrations of suspended solids in the inflow were much greater than the outflow. Water overflowed the drop outlet on three occasions, and during these times, the discharge-weighted concentrations of suspended solids in the outflow exceeded those of the inflow.

Discharge-weighted concentrations of dissolved solids were smaller in the inflow than in the outflow for all but one of the storms analyzed. Dischargeweighted concentrations of dissolved solids in the inflow ranged from 47 to $410 \mathrm{mg} / \mathrm{L}$ and from 92 to $352 \mathrm{mg} / \mathrm{L}$ in the outflow. A possible explantion for increase in discharge-weighted concentrations in the outflow probably is due to the mineralization of organic matter deposited on the filter and dissolution of evaporites and dust that are leached from the pond bed and filter system.

Most of the nitrogen in Pond 1 at the mall is introduced as ammonia or organic nitrogen, or both. Discharge-weighted concentrations of total ammonia plus organic nitrogen were substantially larger in the inflow than were concentrations of total nitrite plus nitrate nitrogen. Concentrations of total ammonia plus organic nitrogen al so were much larger in the inflow than in the outflow. Concentrations of total nitrite plus nitrate nitrogen were substantially smaller in the inflow than in the outflow and were larger in the outflow than discharge-weighted concentrations of total ammonia plus organic nitrogen. Organic and ammonia nitrogen trapped in the pond from previous storms and in the water as it flows through the filter system are oxidized to nitrite and nitrate nitrogen.

Peak concentrations or densities of most constituents in the inflow were substantially larger than those in the outflow. Exceptions were noted for peak concentrations of total nitrite plus nitrate nitrogen and for dissolved solids. Peak concentrations for these constituents were smaller in the inflow than in the outflow for the six storms with discrete sample analysis.

Similarly, loads of most constituents and total densities of bacteria at the mall site were substantially larger in the inflow than in the outflow. The total densities of bacteria at the outflow were less by about 80 percent. Average removal efficiencies of the pond and (or) the filter system for suspended 
solids, biochemical oxygen demand, total phosphorus, total organic carbon, chemical oxygen demand, and dissolved zinc were between 60 and 80 percent. The average dissolved load was about 13 percent 1 arger in the outflow than in the inflow. Average loads of total nitrite plus nitrate nitrogen were about 110 percent 1 arger in the outflow than in the inflow. The increase in loads of these constituents is due to oxidation and mineralization of previously deposited material and subsequent leaching from the bed of the pond or from the filter system.

Rainfall totals for storms analyzed at Al ta Vista ranged from 0.25 to 2.00 in. The maximum rainfall recorded was $0.30 \mathrm{in}$. for 5 minutes, 0.50 in. for 10 minutes, and $0.65 \mathrm{in}$. for 15 minutes. Inaccuracies of discharge measured at the outflow site and the variation of the drainage area of the outflow site with the intensity of rainfall prevented a hydrologic analysis of the basin above this station. The runoff-rainfall ratio for the basin above the inflow station ranged from 0.18 to 0.71 and averaged 0.42 . The maximum peak discharge at the inflow station for the selected storms was $0.93 \mathrm{ft}^{3} / \mathrm{s}$.

Discharge-weighted concentration data for Alta Vista indicate that the grass-covered swales and the grass-covered detention area had little or no effect on reducing concentrations or densities of most water-quality constituents. Discharge-weighted concentrations of total phosphorus were 1 arger in the outflow than in the inflow for every storm analyzed. Discharge-weighted concentrations of dissolved solids and volatile dissolved solids were 1 arger in the outflow than in the inflow for at 1 east 16 of the 19 storms analyzed.

Discharge-weighted concentrations of biochemical oxygen demand, chemical oxygen demand, and total organic carbon were 1 arger in the outflow than in the inflow for at least 12 of the 19 storms analyzed. Discharge-weighted densities of fecal streptococci were reduced between the inflow and outflow, with discharge-weighted densities of fecal streptococci being smaller in the outflow for 15 of the 18 storms analyzed.

Because of the relatively small variation in concentrations and densities of constituents between the inflow and outflow sites, and because of the errors in discharge at the outflow gage, it was not feasible to determine the effect of the grass-covered swales on discharge-weighted concentrations and densities of water-quality constituents.

Peak concentrations or densities of most constituents were not reduced at Alta Vista. Peak concentrations of dissolved solids in the outflow exceed peak concentrations in the inflow for all five of the storms analyzed with discrete samples. Peak concentrations of suspended solids, total ammonia plus organic nitrogen, total nitrite plus nitrate nitrogen, total nitrogen and dissolved iron were 1 arger than or equal to in the outflow than in the inflow for four of the five storms analyzed.

Although the authors acknowledge errors in measurement of discharge at the outflow station, the consistently larger measured peak concentrations at the outflow station strongly indicate that concentrations of most water-quality constituents are not reduced by the grass swales and small detention area. 
Load removal efficiencies of water-quality constituents could not be determined at the Alta Vista area because of inaccuracies in measuring discharge at the outflow. 


\section{SELECTED REFERENCES}

Baker, E. T., Jr., and others, 1984, Geohydrology of the Edwards aquifer in the Austin area, Texas: U.S. Geological Survey Open-File Report 84-864, 238 p.

Brune, Gunnar, and Duffin, G. L., 1983, Occurrence, availability, and quality of ground water in Travis County, Texas: Texas Department of Water Resources Report 276, $219 \mathrm{p}$.

Carter, C. W., 1975, Analysis of extreme rainfall events occurring at Austin, Texas: Austin, Texas, Espey, Houston and Associates, Inc., 13 p.

Garner, L. E., and Young, K. P., 1976, Environmental geology of the Austin area; An aid to urban planning: Austin, University of Texas, Bureau of Economic Geology Report of Investigations 86, $39 \mathrm{p}$.

Geldriech, E. E., and Kenner, B. A., 1969, Concepts of fecal streptococci in stream pollution: Federal Water Pollution Control Association Journal, v. 41, p. 336-352.

Guy, H.P., 1969, Laboratory theory and methods for sediment analysis: U.S. Geological Survey Techniques of Water-Resources Investigations, Book 5, Ch. $\mathrm{C} 1,58 \mathrm{p}$.

Hem, J. D., 1970, Study and interpretation of the chemical characteristics of natural water (2d ed.): U.S. Geological Survey Water-Supply Paper 1473, $363 \mathrm{p}$.

Rodda, P. U., Garner, L. E., and Dawe, G. L., 1970, Geology of the Austin West quadrangle, Travis County, Texas: Austin, University of Texas, Bureau of Economic Geology Geologic Quadrangle Map 38, scale 1:24,000, 11 p.

Skougstad, M. W., Fishman, M. J., Friedman, L. C., Erdmann, P. E., and Duncan, S. S., 1979, Methods for determination of inorganic substances in water and fluvial sediments: U.S. Geological Survey Techniques of Water-Resources Investigations, Book 5, Ch. A3, $626 \mathrm{p}$.

U.S. Department of Agriculture, Soil Conservation Service, 1972, National engineering handbook; Hydrology: Sec. 4, Ch. 10.

U.S. Department of Commerce, 1981, Local cl imatological data, monthly summaries and annual summary with comparative data, 1981, Dallas-Fort Worth: U.S. National Oceanic and Atmospheric Administration, Environmental Data and Information Service.

U.S. Geological Survey, 1976, Hydrologic unit map--1974, State of Texas: U.S. Geological Survey, scale 1:500,000, 4 sheets.

Wells, F. C., and Shertz, T. L., 1984, Computation and use of volume-weightedaverage concentrations to determine long-term variations of selected water-quality constituents in lakes and reservoirs: U.S. Geological Survey Water-Resources Investigations Report $83-4287,8 \mathrm{p}$.

Wershaw, R. L. Fishman, M. J. Grabbe, R. R. and Lowe, L. E., 1983, Methods for the determination of organic substances in water and fluvial sediments: U.S. Geological Survey Techniques of Water-Resources Investigations, Book 5, Ch. A3, $173 \mathrm{p}$. 


\section{GLOSSARY OF SELECTED WATER-QUALITY TERMS}

Biochemical oxygen demand (BOD).--BOD is a measure of the quantity of dissolved oxygen necessary for the decomposition of organic matter by microorganisms, such as bacteria. Sources of organic debris may be from industrial and municipal waste or from naturally occurring decaying plants and animals. The unit is milligrams per liter $(\mathrm{mg} / \mathrm{L})$.

Chemical oxygen demand (COD).--COD is a measure of the chemically oxidizable material in water and furnishes an approximation of the amount of organic and reducing material present in water. Sources of COD include organic waste, both natural and manmade as well as reduced forms of inorganic matter. The unit is milligrams per liter.

Dissolved solids.--Dissolved solids are the anhydrous residues of the dissolved substances in water. In reality, the term "dissolved solids" is defined by the method of determination. In most waters, the dissolved solids consist predominantly of silica, calcium, magnesium, sodium, potassium, carbonate, bicarbonate, chloride, and sulfate with minor or trace amounts of other inorganic constituents. The unit is milligrams per liter.

Dissolved trace elements.--These elements include those constituents whose concentrations usualiy do not exceed $1 \mu \mathrm{g} / \mathrm{L}$. The trace elements included in this report include dissolved cadmium, dissolved lead, dissolved iron, and dissolved zinc.- The occurrence of most of these trace elements in water is of concern primarily because of the potentially harmful effects of excessive concentrations on human, animal, and aquatic 1 ife. The unit is micrograms per 1 iter $(\mu \mathrm{g} / \mathrm{L})$.

Fecal-coliform and fecal-streptococcal bacteria.--The coliform group of bacteria has been used as an indicator of the sanitary quality of water since the $1880^{\prime} \mathrm{s}$. Fecal-coliform bacteria are present in the intestines and feces of warm-blooded animals, and their occurrences in water reflect the presence of fecal contamination, which is the most likely source of pathogenic microorganisms. Fecalstreptococcal bacteria also occur in the intestines of warm-blooded animals, and their presence in water is considered to verify fecal pollution (Geldreich and Kenner, 1969, p. 348). One potentially valuable application of the fecal-streptococcal group is its correlation with the fecal-coliform group as an aid in identifying sources of pollution. According to Geldreich and Kenner (1969, p. 349), the ratio of fecal-coliform bacteria to fecal streptococcal-bacteria in the feces of man and in fresh domestic wastewaters always is greater than 4.0. The same ratio in the feces of farm animals, cats, dogs, and rodents from separate stormwater systems and farmland drainage generally is less than 0.7. However, Geldreich and Kenner caution that the use of the ratio for distinguishing between human and animal sources would be valid only during the initial 24-hour travel time from the point of pollution because the attrition rate of the two forms of bactria are different. The unit is colonies per 100 milliters (cols./100 mL). The letter "K" appearing in the tables beside values for this constituent means the density is based on a non-ideal colony count. 
Specific conductance.--This property is a measure of the ability of water to conduct an electrical current and is related to the types and concentrations of ions in solution. The specific conductance of a solution increases as the ionic concentration increases. Consequentiy, the measurement of the specific conductance of water is useful as a general indication of the dissolved-solids concentration and as a base for extrapolating concentrations of the major ions, when comprehensive analyses are available for some of the samples (Hem, 1970, p. 99). The unit is microsiemens per centimeter at $25^{\circ} \mathrm{C}(\mu \mathrm{S} / \mathrm{cm})$.

Suspended solids.--Suspended solids include any organic or inorganic material held in suspension by water, including silt and clay particles as well as decaying organic matter. Suspended solids generally transport nutrients, pesticides, trace metals, or other constituents that may be absorbed or adhere to the suspended particles. The unit is milligrams per liter.

Total nitrogen species and total phosphorus.--These elements are components of the metabolic wastes of humans, animals and fertilizer. Phosphorus also is a component of household detergents. Presence of these compounds may be indicative of the presence of pollution from these sources. However, these elements also may occur naturally as a result of leaching of soils and rocks and the decomposition of $\mathrm{plant}$ and animal material.

Nitrogen is a cyclic element and may occur in several forms. The forms, in order of increasing oxidation state, are organic nitrogen, ammonia nitrogen, nitrite nitrogen, and nitrate nitrogen. Nitrate is the most stable form of nitrogen in an oxidizing environment and usually is the dominant form of nitrogen in natural waters and in polluted waters that have undergone selfpurification or aerobic treatment processes. The nitrogen species and phosphorus are reported in milligrams per liter.

Total organic carbon (TOC).--TOC is a measure of the amount of organic carbon in water. Although organic carbon in water is not a direct indicator of pollution, concentrations greater than about $1 \mathrm{mg} / \mathrm{L}$ in ground water and about 5 $\mathrm{mg} / \mathrm{L}$ in surface water may be presumptive evidence of pollution.

Volatile dissolved solids.--Volatile dissolved solids is the amount of weight loss when the dissolved solids residue is heated to $550^{\circ} \mathrm{C}$. The unit is milligrams per liter. 